\title{
DEVELOPMENT OF DISPOSABLE SORBENTS FOR CHLORIDE REMOVAL FROM HIGH TEMPERATURE COAL-DERIVED GASES
}

Final Technical Report

Covering the period from October 1993 to June 1999

Gopala Krishnan

SRI International

Raghubir Gupta

Research Triangle Institute

Contract No.: DE-AC21-93MC30005--02

September 1999

SRI Project PYU 5318

RTI Project 93U-5788 


\section{DISCLAIMER}

This report was prepared as an account of work sponsored by an agency of the United States Government. Neither the United States Government nor any agency thereof, nor any of their employees, makes any warranty, express or implied, or assumes any legal liability or responsibility for the accuracy, completeness, or usefulness of any information, apparatus, product, or process disclosed, or represents that its use would not infringe privately owned rights. Reference herein to any specific commercial product, process, or service by trade name, trademark, manufacturer, or otherwise does not necessarily constitute or imply its endorsement, recommendation, or favoring by the United States Government or any agency thereof. The views and opinions of authors expressed herein do not necessarily state or reflect those of the United States Government or any agency thereof. 


\begin{abstract}
Advanced integrated-gasification combined-cycle (IGCC) and integrated-gasification fuel cell (IGFC) systems require the development of high temperature sorbents for the removal of hydrogen chloride $(\mathrm{HCl})$ vapor to less than 1 parts-per-million $(\mathrm{ppm})$ levels. $\mathrm{HCl}$ is a highly reactive, corrosive, and toxic gas which must be removed to meet environmental regulations, to protect power generation equipment, and to minimize deterioration of hot gas desulfurization sorbents. The objective of this program was to develop disposable, alkali-based sorbents capable of reducing $\mathrm{HCl}$ vapor levels to less than $1 \mathrm{ppm}$ in the temperature range from $400^{\circ}$ to $750^{\circ} \mathrm{C}$ and pressures in the range from 1 to $20 \mathrm{~atm}$. The primary areas of focus of this program were to investigate different methods of sorbent fabrication, testing their suitability for different reactor configurations, obtaining reaction kinetics data, and conducting a preliminary economic feasibility assessment. This program was a joint effort between SRI International (SRI), Research Triangle Institute (RTI), and General Electric Corporate Research and Development (GE-CRD). SRI, the prime contractor and RTI, a major subcontractor, performed most of the work in this program.

Thermochemical calculations indicated that sodium-based sorbents were capable of reducing $\mathrm{HCl}$ vapor levels to less than $1 \mathrm{ppm}$ at temperatures up to $650^{\circ} \mathrm{C}$, but the regeneration of spent sorbents would require complex process steps. Nahcolite $\left(\mathrm{NaHCO}_{3}\right)$, a naturally-occurring mineral, could be used as an inexpensive sorbent to remove $\mathrm{HCl}$ vapor in hot coal gas streams. In the current program, nahcolite powder was used to fabricate pellets suitable for fixed-bed reactors and granules suitable for fluidized-bed reactors. Pilot-scale equipment were used to prepare sorbents in large batches: pellets by disk pelletization and extrusion techniques, and granules by granulation and spray-drying techniques. Bench-scale fixed- and fluidized-bed reactors were assembled at SRI and RTI to conduct tests at high-temperature, high-pressure conditions (HTHP). The HTHP tests confirmed the ability of nahcolite pellets and granules to reduce the $\mathrm{HCl}$ vapor levels to less than 1 ppm levels with a very high sorbent utilization for chloride capture. The effect of several operating variables such as temperature, pressure, presence of hydrogen sulfide, and sorbent preparation methods was studied on the efficacy of $\mathrm{HCl}$ removal by the sorbent. Pilot-scale tests were performed in the fluidized-bed mode at the gasifier facility at the GE-CRD. Sorbent exposure tests were also conducted using a hot coal gas stream from the DOE/FETC's fluidized-bed gasifier at Morgantown, WV. These tests confirmed the results obtained at SRI and RTI. A preliminary economic assessment showed that the cost of $\mathrm{HCl}$ removal in a commercial IGCC system will be about $\$ 0.001 / \mathrm{kWh}(1 \mathrm{mills} / \mathrm{kWh})$.
\end{abstract}




\section{ACKNOWLEDGMENTS}

This research was sponsored by U.S. Department of Energy's Federal Energy Technology Center (FETC) under contract No.: DE-AC21-93MC30005. Valuable guidance and suggestions provided by Messers Suresh Jain, Ronald Staubly, and Thomas Feeley, acting as DOE's Contracting officer's Representatives (COR), are gratefully acknowledged. Also acknowledged are the guidance of Mr. Daniel Cicero and the assistance provided by DOE/FETC's staff during field testing of the process.

The contribution of Drs. Raul Ayala and Venkat Venkataramani is acknowledged for performing pilot-scale tests at GE-CRD hot gas test facility and assisting in the development of fixed- and moving-bed reactor sorbents.

The following scientific and technical personnel participated in the work performed at SRI: Ms. Anastasia Canizales (SRI) assembled the bench-scale fixed-bed reactor test facility and performed many experimental tests in it; Mr. Bernard Wood provided valuable technical advice, procured the sorbent powder, and arranged for the fabrication of pellets; Dr. Jon McCarty developed the mathematical model for the fixed-bed reactor kinetics; Mr. Victor Wong assembled the skid-mounted reactor system for tests at DOE's MGCR facility; Drs. Angel Sanjurjo, Kai-Hung Lau, and Donald Hildenbrand provided valuable technical advice.

The following scientific and technical personnel participated in the work performed at RTI: Dr. Suhas Shelukar and Mr. Russell Williams conducted fluidized-bed experimental work. Mr. Jeffrey Porter and Dr. Brian Turk assisted in designing and constructing the skid-mounted fluid-bed reactor system for tests at DOE's MGCR facility; Messers. Daryl Smith and Ernest Johnson assembled the bench-scale and skid-mounted units. Messers Daniel Ward, Gary Folsom, and Gary Howe and Dr. Santosh Gangwal provided valuable technical assistance. 


\section{TABLE OF CONTENTS}

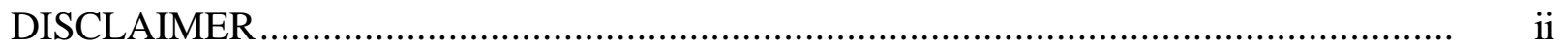

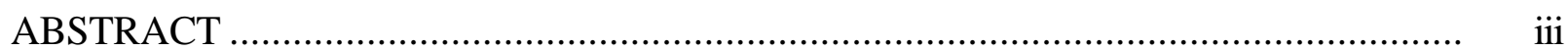

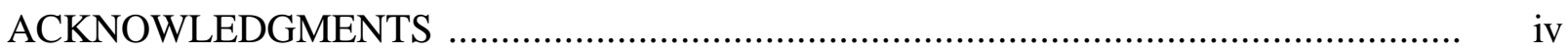

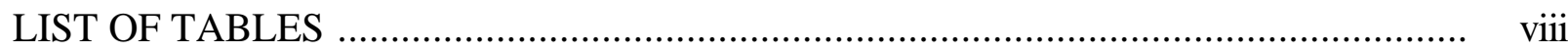

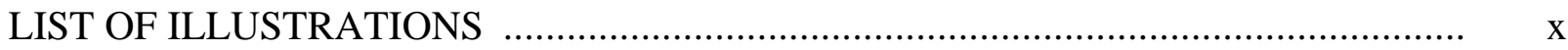

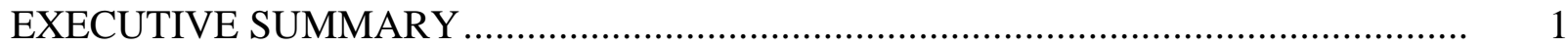

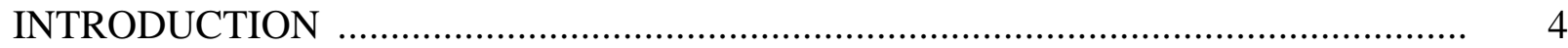

Need for Removal of Hydrogen Chloride Vapor .............................................................

The Extent of Occurrence of $\mathrm{HCl}$ Vapor in Coal Gasification Systems......................... 4

Need for $\mathrm{HCl}$ Removal in IGCC Power Generation Systems........................................ 5

Need for $\mathrm{HCl}$ Removal in Hot Gas Cleanup Systems .................................................... 6

Previous Studies for $\mathrm{HCl}$ Removal .....................................................................

Program Objectives ............................................................................................

SORBENT PREPARATION AND CHARACTERIZATION …………........................... 10

Thermodynamic Considerations............................................................................. 10

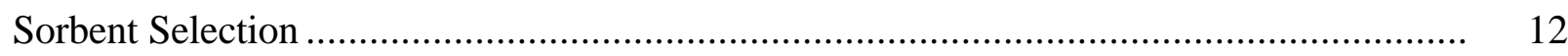

Occurrance of Sodium Carbonate Minerals..................................................................... 13

Reactivity of Nahcolite Powder ……............................................................................. 14

Fabrication and Characterization of the Sorbent Pellets ............................................... 16

Fabrication of Sorbent Pellets ......................................................................... 16

Physical Properties of the Pellets ........................................................................ 16

Reactivities of the Extruded Pellets for $\mathrm{HCl}$ Absorption ............................................. 25

Fabrication and Characterization of Fludized-Bed Sorbents ............................................. 28

Sorbent Compositions Investigated................................................................. 29

Fabrication of Nahcolite Sorbents ....................................................................... 29

Physical Properties of Fluidized-Bed Sorbents ……………................................... 31

Sorbent Reactivity Studies ................................................................................. 33

Sorbents for Moving-Bed Reactors ………………………………………………... 40

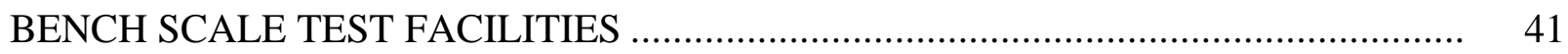


Atmospheric Test Facility for Sorbent Screening Studies ............................................... 41

Fixed-Bed Reactor System …………............................................................ 41

Fluidized-Bed Reactor System............................................................................. 43

High Pressure Test Facilities............................................................................... 43

Fixed-Bed Reactor System ............................................................................ 43

Fluidized-Bed Reactor System.......................................................................... 46

Circulating-fluidized-bed Reactor System .......................................................... 49

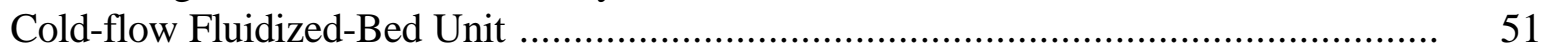

Ion Chromatograph for $\mathrm{HCl}$ Analysis...................................................................... 52

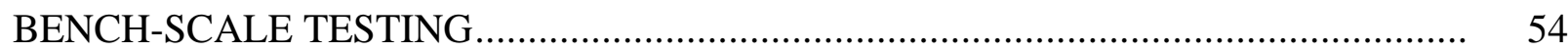

Gas Composition ................................................................................................. 54

Fixed-Bed Reactor Tests .................................................................................. 55

Reactor Performance Verification .................................................................... 55

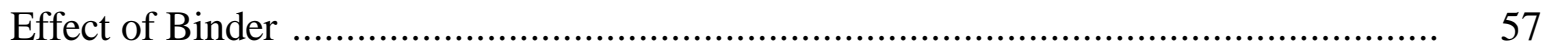

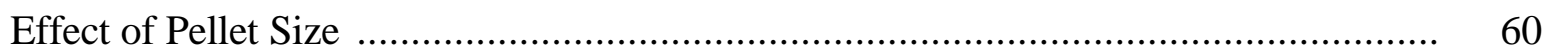

Effect of Hydrogen Sulfide in the Coal Gas ........................................................... 62

Effect of Pressure .................................................................................... 65

Test with Other Chloride Removal Sorbents .......................................................... 67

Fluidized-Bed Reactor Tests .............................................................................. $\quad 70$

Influence of Sorbent Preparation Method on Chloride Capture Capacity ..................... $\quad 70$

Influence of Fluidization Velocity ......................................................................... $\quad 70$

High Pressure Fluidized-Bed Reactor Tests ............................................................ 72

Effect of Pressure on HCl Removal by Nahcolite Sorbent NS-01 ............................. 72

Effect of Steam Concentration ..........................................................................

Atmospheric Entrained-Bed Studies ................................................................... 76

Reactivity of Moving-Bed Reactor Sorbents ............................................................... 78

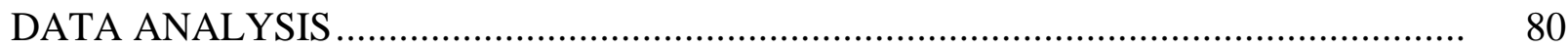

Fixed-Bed Reactor Data .............................................................................. 80

Fluidized- and Entrained-Bed Data ....................................................................... 84

PILOT-SCALE TESTING OF SORBENTS $\ldots$

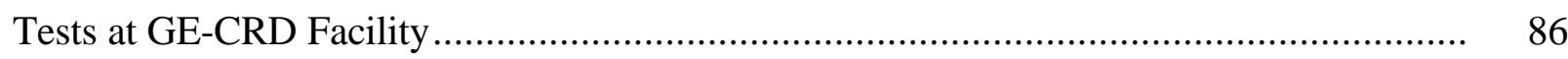

Sorbent Flowability Studies .................................................................................... 90

Tests at the FETC NGCR Facility ……….................................................................... 91

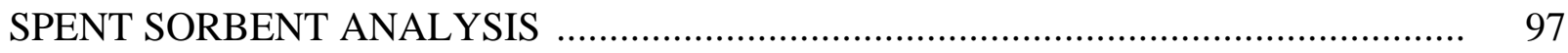

PRELIMINARY ECONOMIC ASSESSMENT ………............................................ 102

Conceptual System Configurations ......................................................................... 102 
Chloride Sorbent Selection ............................................................................... 103

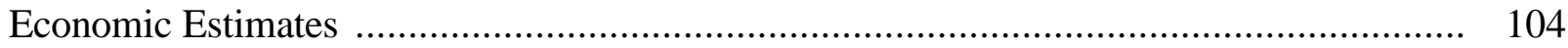

Process Design Bases and Process Description ...................................................... 104

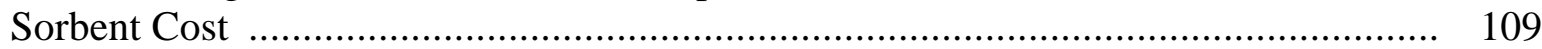

Capital Investment ……..................................................................... 110

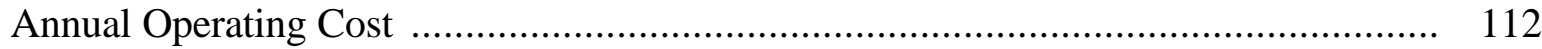

Economic Sensitivity Studies ......................................................................... 113

CONCLUSIONS AND RECOMMENDATIONS ……......................................... 117

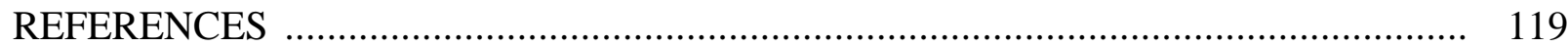




\section{LIST OF TABLES}

1. Equilibrium vapor pressures over alkali and alkaline earth chlorides............................ 10

2. Changes in surface area of nahcolite powder with temperature .................................. 15

3. Pellet processing parameters during extrusion........................................................ 17

4. Surface area of nahcolite pellets made by disc pelletization as a function of temperature 17

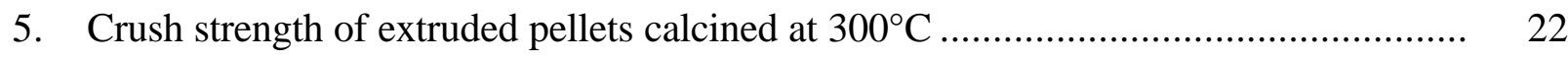

6. Some physical properties of pelletized sorbents …….................................................. 22

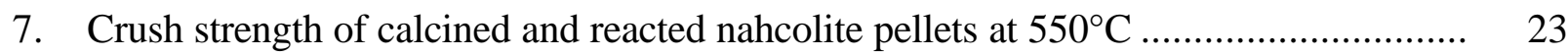

8. Chloride uptake by various fixed-bed reactor sorbents as a function of exposure

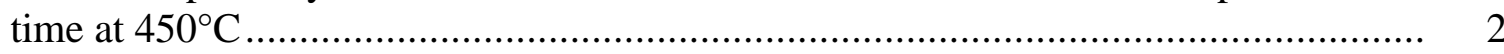

9. Chloride uptake by various fixed-bed reactor sorbents as a function of exposure time at $550^{\circ} \mathrm{C}$

10. A comparison of the $\mathrm{Na}_{2} \mathrm{CO}_{3}$ content and the estimated chloride capacity of

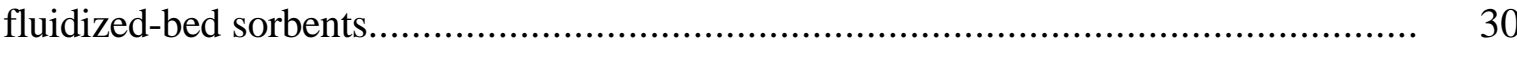

11. Attrition resistance of fluidized-bed sorbents ........................................................... 31

12. Physical properties of the fresh, calcined, and spent granulated (N-23) nahcolite sorbent

13. Physical properties of the fresh, calcined, and spent non-granulated $(\mathrm{N}-01)$ nahcolite sorbent

14. Comparison of physical and chemical properties of fresh and reacted NS-01 sorbents. 34

15. Influence of calcination temperature on surface area of the NS-01 sorbent.................. 35

16. Gas composition of simulated coal gas mixtures ........................................................ 54

17. Chloride capacity, porosity and surface area of fluidized-bed sorbents ........................ 71

18. Chloride capacity of NS-01 and N-01 sorbents as a function of gas velocity ............... 72

19. Sorbent capacity of N-01 sorbent in the entrained-bed reactor mode experiments ....... 78 
20. $\mathrm{HCl}$ absorption rate constants for fixed-bed reactor sorbents ............................. 82

21. Global rate constants for fluidized- and Entrained-bed reactors............................ 85

22. Angle of repose of $\mathrm{HCl}$ removal sorbents ...................................................

23. Chloride content of the sorbents exposed to hot coal gas at the MGCR facility .......... 96

24. Trace metal levels in the sorbents exposed at the GE-CRD facility ........................ 98

25. Trace metal analysis of spent sorbents exposed at the MGCR facility..................... 99

26. Composition of gas stream through chloride removal unit................................... 105

27. Capital cost of the fixed-bed reactor $\mathrm{HCl}$ removal system ............................... 111

28. Capital cost of the circulating-fluidized-bed reactor $\mathrm{HCl}$ removal system ................ 112

29. Annual cost of the fixed-bed reactor $\mathrm{HCl}$ removal system ................................. 114

30. Annual cost of the circulating-fluidized-bed reactor $\mathrm{HCl}$ removal system ................ 115

31. Economic sensitivity analysis of $\mathrm{HCl}$ vapor removal system ............................. 116 


\section{LIST OF ILLUSTRATIONS}

1. The equilibrium partial pressure of $\mathrm{HCl}$ as a function of temperature at 20 atm in a Texaco coal gasifier gas stream

2. The reactivity of nahcolite powder with $1750 \mathrm{ppm} \mathrm{HCl}$ vapor in nitrogen ................. 15

3. The surface area of extruded pellets as a function of temperature........................... 18

4. The pore size distribution of nahcolite pellets with bentonite (L-07) and sodium silicate

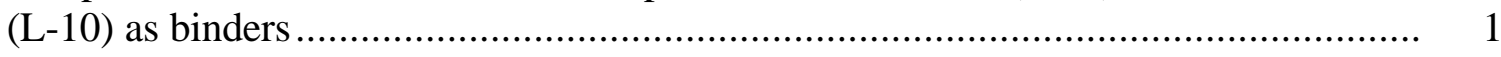

5. Pore size distribution of spent sorbents after reaction at $400^{\circ} \mathrm{C}$ for $32 \mathrm{~h} \ldots \ldots \ldots \ldots \ldots \ldots . . . . . . . . .20$

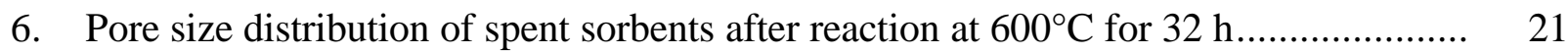

7. Pore size distribution of pellets made by a pellets press after calcination at $500^{\circ} \mathrm{C}$ for $4 \mathrm{~h}$

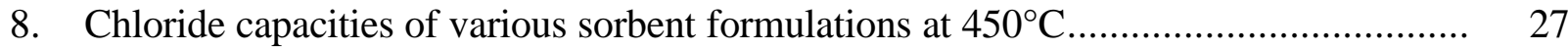

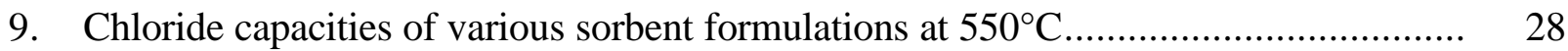

10. Weight loss during calcination of NS-01 sorbent at various temperatures.................. 35

11. The $\mathrm{HCl}$ reactivity of NS-01 sorbent, calcined in-situ, at $350^{\circ}$ to $550^{\circ} \mathrm{C} \ldots \ldots \ldots \ldots \ldots . . . . . . . . .36$

12. The $\mathrm{HCl}$ reactivity of precalcined NS-01 sorbent at temperatures from $350^{\circ}$ to $550^{\circ} \mathrm{C} \quad 37$

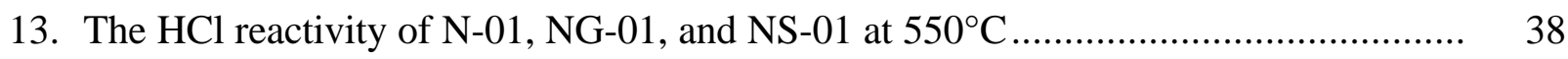

14. Reactivity of NS-01 sorbent at $550^{\circ} \mathrm{C}$ under differential reaction conditions .............. 40

15. Schematic diagram of the 1 -atm fixed-bed reactor .............................................

16. Schematic diagram of the atmospheric fluidized-bed reactor ............................. 44

17. Schematic diagram of the high-pressure fixed-bed reactor system .......................... 45

18. Schematic diagram of the high-pressure, fluidized-bed reactor system...................... 47

19. Schematic diagram of the fluidized-bed reactor............................................. 48

20. Schematic diagram of the circulating-fluidized-bed reactor .............................. 50

21. Typical fluidization behavior of NS-01 sorbent ....................................... 51 
22. The $\mathrm{HCl}$ breakthrough curve for nahcolite sorbent pellets $(\mathrm{N}-08)$ at $500^{\circ} \mathrm{C}$

23. The variation of chloride content of $\mathrm{N}-08$ pellets after $30 \mathrm{~h}$ of reaction at $500^{\circ} \mathrm{C}$

24. The $\mathrm{HCl}$ breakthrough curve of $\mathrm{L}-07$ sorbent at $400^{\circ} \mathrm{C}$ in simulated coal gas containing no $\mathrm{H}_{2} \mathrm{~S}$

25. Variation of chloride content of spent L-07 sorbent pellets as a function of bed depth.

26. The $\mathrm{HCl}$ breakthrough curve of $\mathrm{L}-10$ sorbent at $500^{\circ}$ and $600^{\circ} \mathrm{C}$ in simulated GPIF coal gas containing no $\mathrm{H}_{2} \mathrm{~S}$

27. Variation of chloride content of spent L-10 sorbent pellets as a function of bed depth.

28. The $\mathrm{HCl}$ breakthrough curve of $\mathrm{L}-08$ sorbent at $500^{\circ} \mathrm{C}$ in simulated coal gas containing no $\mathrm{H}_{2} \mathrm{~S}$

29. Variation of chloride content of spent L-08 sorbent pellets as a function of bed depth. 62

30. The reaction between nahcolite powder and hydrogen sulfide at $550^{\circ}$ and $650^{\circ} \mathrm{C}$.......

31. The $\mathrm{HCl}$ breakthrough curves with $\mathrm{L}-07$ sorbent at $400^{\circ}$ and $600^{\circ} \mathrm{C}$ in the presence of $1750 \mathrm{ppm} \mathrm{HCl}$ and $3000 \mathrm{ppm}_{2} \mathrm{~S}$.

32. Variation of chloride content of spent L-07 sorbent pellets as a function of bed depth

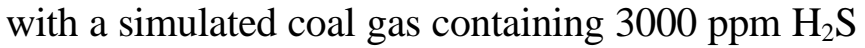

33. The $\mathrm{HCl}$ breakthrough curves with $\mathrm{L}-08$ sorbent at $550^{\circ} \mathrm{C}$ at $150 \mathrm{psig}$.....

34. Variation of chloride content of spent L-08 sorbent pellets as a function of bed depth after reaction at 150 psig with a simulated coal gas containing $3000 \mathrm{ppm}_{2} \mathrm{~S}$

35. The $\mathrm{HCl}$ removal performance of trona vs nahcolite pellets at $500^{\circ} \mathrm{C}$ and $1 \mathrm{~atm} \ldots \ldots \ldots . . . .68$

36. The $\mathrm{HCl}$ removal of performance of UCI Chloride Guard vs. nahcolite pellets

37. The $\mathrm{HCl}$ breakthrough curve for $\mathrm{N}-01, \mathrm{~N}-23$, and $\mathrm{NS}-02$ sorbents in a fluidized-bed reactor at $550^{\circ} \mathrm{C}$

38. The $\mathrm{HCl}$ removal efficiency of trona compared to NS-02 sorbent

39. The effect of pressure on the $\mathrm{HCl}$ removal in the fluidized-bed reactor.

40. The effect of steam levels in the feed gas on the $\mathrm{HCl}$ removal efficiency of NS-02 sorbent

41. The $\mathrm{HCl}$ removal efficiency of nongranulated (N-01 and) spray-dried nahcolite (NS-01) sorbents in the entrained-bed reactor 
42. The $\mathrm{HCl}$ breakthrough curves with $\mathrm{MM} 2$ sorbent at $500^{\circ} \mathrm{C}$ in the presence of $1750 \mathrm{ppm} \mathrm{HCl}$.

43. Comparison of actual and predicted $\mathrm{HCl}$ breakthrough curve at $500^{\circ} \mathrm{C}$ for $\mathrm{L}-07$ pellets 83

44. Comparison of actual and predicted chloride loading as a function of bed depth at $500^{\circ} \mathrm{C}$ for L-07 pellets

45. The measured $\mathrm{HCl}$ level during the pilot-scale test at GE-CRD with the spraydried sorbent

46. Sorbent utilization and the $\mathrm{HCl}$ removal efficiency during the pilot-scale test at GE-CRD

47. Schematic diagram of the sorbent beds in the skid-mounted system used for hot coal gas exposure tests at DOE-FETC's MGCR unit

48. Schematic diagram of the skid-mounted fixed-bed reactor system used for hot coal gas exposure tests at DOE-FETC's MGCR unit

49. Schematic diagram of the skid-mounted fluidized-bed reactor system used for hot coal gas exposure tests at DOE-FETC's MGCR unit

50. Schematic diagram of a fixed-bed reactor process for $\mathrm{HCl}$ vapor removal from hot coal gas 106

51. Schematic diagram of a CFB reactor process for $\mathrm{HCl}$ vapor removal from hot coal gas 


\section{EXECUTIVE SUMMARY}

The objective of this program was to develop alkali-based disposable sorbents capable of reducing hydrogen chloride $(\mathrm{HCl})$ vapor concentrations to less than 1 parts-per-million $(\mathrm{ppm})$ in coal gas streams at temperatures from $400^{\circ}$ to $750^{\circ} \mathrm{C}\left(750^{\circ}\right.$ to $\left.1380^{\circ} \mathrm{F}\right)$ and pressures from 1 to 20 atm. The primary areas of focus of this program were investigation of different processes for fabricating the sorbents, testing their suitability for different reactor configurations, obtaining kinetic data, and updating the economics of the process.

During gasification, chloride species in coal are converted to $\mathrm{HCl}-$ a reactive, corrosive, and toxic gas- that must be removed to meet environmental regulations, to protect power generation equipment, and to minimize deterioration of hot coal gas desulfurization sorbents. The actual concentration of $\mathrm{HCl}$ vapor in a coal gas stream will depend on the chlorine content of the coal, the gasification temperature, and the type of gasifier. Recent measurements show that the concentration of $\mathrm{HCl}$ vapor is about $300 \mathrm{ppmv}$ in the gas stream from a fixed-bed gasifier using a coal containing $0.24 \mathrm{wt} \%$ chlorine. High-temperature molten carbonate fuel cells (MCFCs) require a feed gas nearly free of $\mathrm{HCl}$ because $\mathrm{HCl}$ reacts with the electrolytes to form halides such as $\mathrm{LiCl}$ and $\mathrm{KCl}$ and causes increase in cell resistance. The tolerance level of MCFCs for $\mathrm{HCl}$ vapor is less than $1 \mathrm{ppm}$. The effect of impurity $\mathrm{HCl}$ in coal gas feed for gas turbines is not welldefined, but chloride deposits on syngas coolers could accelerate the rate of corrosion of the heat exchanger material. $\mathrm{HCl}$ vapor in the hot coal gas streams was also found to react with $\mathrm{ZnO}$-based desulfurization sorbents forming zinc chlorides and causing problems during their regeneration.

Thermodynamic calculations indicate that sodium-based sorbents are capable of reducing $\mathrm{HCl}$ vapor to less than $1 \mathrm{ppm}$ in coal gas streams up to a temperature of $650^{\circ} \mathrm{C}$, but they are not easily regenerable. The mineral nahcolite $\left(\mathrm{NaHCO}_{3}\right)$ could be used as an inexpensive $\mathrm{HCl}$ scavenging sorbent suitable for fixed- and fluidized-bed reactors.

Fixed-and fluidized-bed reactors were used to test various sorbent formulations at the bench-scale level. Sorbent pellets suitable for fixed-bed applications were manufactured by disc pelletization and extrusion using pilot-scale facilities. Granules suitable for bubbling fluidized- and circulating-fluidized-bed systems (CFB) were also manufactured using the spray-drying process. The physical characteristics of fresh and spent sorbents were determined for several sorbent formulations. Binders, such as bentonite, appeared to be necessary to maintain the reactivity of the 
sorbent at high temperatures. High sorbent capacity utilization may not be achieved by the use of raw powder alone.

Parametric tests with temperature, steam level, and total pressure showed that these parameters had only minor effects on the $\mathrm{HCl}$ reactivity and chloride capacity of the sorbent. Increasing the temperature increased the residual $\mathrm{HCl}$ concentration but allowed higher chloride capacities. These results could be explained by thermodynamic and kinetic considerations. Steam levels from 15 to $25 \%$ had only a small effect on sorbent performance. Total pressure had negligible effect on the fixed-bed reactor performance, but sorbent agglomeration and channeling occurred in the bench-scale fluidized-bed reactor operating in a bubbling mode. Increasing the gas velocity to approach that encountered in entrained-bed systems allowed better contact between the sorbent bed and the gas. Operating the reactor under circulating-fluidized-bed mode has been shown to be effective under pressurized conditions.

High levels of $\mathrm{HCl}$ vapor removal (>95\%) were demonstrated in pilot-scale tests at the General Electric Corporate Research and Development (GE-CRD) fixed-bed gasifier facility. Sorbent capacity utilization of about $55 \%$ was achieved with a commercial baking soda powder, and even greater utilization $(\sim 75 \%)$ was achieved with spray-dried sorbents.

Accumulation of trace metal components in the sorbents could not be precisely measured. In the tests at the GE-CRD fixed-bed gasifier, the only metal component that was accumulated significantly was lead $(\mathrm{Pb})$ and it was only on the spray-dried sorbent. The baking soda powder, used during the major portion of the test, showed only small amounts of lead accumulation. Because of the limited duration $(4 \mathrm{~h})$ of the test with the spray-dried sorbent, the results may not be representative. An exposure test at the U.S. Department of Energy - Federal Energy Technology Center's (DOE/FETC) Modular Gas Cleanup Rig (MGCR) facility did not show any significant accumulation of trace metal components.

Economic calculations indicate that the cost of removal of $\mathrm{HCl}$ vapor from hot coal gas streams is only about $\$ 0.001 / \mathrm{kWh}(0.9$ to $1.4 \mathrm{mills} / \mathrm{kWh})$. Fixed-bed reactors appear to be the least expensive method because of their simple configuration and ability to achieve high chloride capture capacities. Major cost components are the cost of feed sorbent and the disposal of the spent sorbent. The cost of using fluidized-bed reactor systems is not significantly different from that of the fixed-bed systems. In CFB reactor applications, in spite of the high cost of preparing the granules, the cost of $\mathrm{HCl}$ vapor removal by using spray-dried sorbents ( $1.4 \mathrm{mills} / \mathrm{kWh})$ could be less than that by using baking soda powder (1.8 mills/kWh) because of the high reactivity and chloride capacity of the spray-dried nahcolite sorbents. 
In conclusion, bench-scale experiments in the fixed- and fluidized-bed reactors have demonstrated that nahcolite pellets and granules are capable of reducing $\mathrm{HCl}$ levels to less than $1 \mathrm{ppm}$ in high temperature coal gas streams in the temperature range $400^{\circ}$ to $650^{\circ} \mathrm{C}$. The sorbents, prepared by pelletizing or spray-drying the natural mineral, nahcolite, have a high capacity for absorbing $\mathrm{HCl}$ vapor. A mathematical analysis of $\mathrm{HCl}$ breakthrough data and chloride level in the spent sorbents suggests that the rate of $\mathrm{HCl}$ uptake by the sorbent is governed by gasphase diffusion, and it could be described by an overall first-order kinetics. A test in a pilot-scale fixed-bed gasifier established that nahcolite can be used successfully for reducing $\mathrm{HCl}$ vapor with high sorbent utilization.

Based on the results of this study, continued testing of the $\mathrm{HCl}$ removal using nahcolite sorbent with gas streams from operating gasifiers is recommended. These tests are necessary to identify any engineering issues and define the cost of $\mathrm{HCl}$ removal more accurately. Some coal utilization applications such as chemicals manufacturing and integrated-gasification fuel cell (IGFC) systems with fuel cells may require $\mathrm{HCl}$ levels significantly lower than $1 \mathrm{ppm}$. Research efforts should focus on identifying and developing concepts that would reduce $\mathrm{HCl}$ vapor levels to parts-per-billion (ppb) levels. 


\section{INTRODUCTION}

\section{NEED FOR REMOVAL OF HYDROGEN CHLORIDE VAPOR}

In the United States, coal is a significant source of fossil fuel energy. Coal is a complex and heterogeneous substance that contains several impurities, including sulfur, chlorine, nitrogen, and metal compounds. During gasification (reaction of coal with steam to form coal gas containing $\mathrm{CO}$ and $\mathrm{H}_{2}$ ), many of these impurities are converted to gaseous species such as $\mathrm{H}_{2} \mathrm{~S}$, $\mathrm{HCl}$, and $\mathrm{NH}_{3}$. Effective removal of impurities from coal gas is necessary to meet environmental standards and to protect electric power generating equipment such as gas turbines and fuel cells which can use coal gas at elevated temperatures. Hence, there is a strong incentive to preserve the enthalpy represented by this hot coal gas and improve the thermal efficiency of electric power generation using coal as the fuel. For this reason, impurities should be removed from the gas stream at high temperatures. High-temperature gas purification also allows contaminants to be removed in their chemically reactive state. Furthermore, in a plant of comparable size, the volume of a coal gas stream is generally less than that of a combustor flue gas stream because the coal gas stream contains only the fuel component and the oxidizing air has not been added yet. Hence, capital and operating costs for contaminant removal are low. Indeed, the primary recommendation of the DOE Coal Gasification Research Needs Panel was the development of hot gas cleanup techniques (COGRAN, 1987).

\section{The Extent of Occurrence of HCl Vapor in Coal Gasification Systems}

Of the several impurities found in coal, sulfur species are usually the major undesirable ones and their removal $\left(\mathrm{H}_{2} \mathrm{~S}\right.$ and $\left.\mathrm{COS}\right)$ has attracted the greatest attention. In some coals, such as those from Illinois, chlorine species are the second most common contaminant (Chou, 1991). The chlorine content of Illinois and other midwest bituminous coals can be as high as $0.6 \mathrm{wt} \%$, well above the estimated $0.1 \mathrm{wt} \%$ average chlorine content of all U.S. coals (Ruch et al., $1974 \mathrm{a}, \mathrm{b}$ ). The coals with the highest chlorine were found in the south-center portion of Illinois; their chlorine content increasing with the depth of the coal seams (Gluskoter and Rees, 1964). The decrease in the ratio of surface ( $<50 \mathrm{~m}$ deep) to underground tonnage mined from 1.45 in 1968 to 0.43 in 1990 has increased the average chlorine content of most of the Illinois coals.

During gasification, the chlorine in the coal is volatilized as $\mathrm{HCl}$ or metal chlorides. In fact, the presence of chlorine accelerates the volatility of other metal species in coal, including alkali 
metals. Typical concentrations of $\mathrm{HCl}$ in coal gas streams have been reported to vary widely. Bakker and Perkins (1991) pointed out that coal gas can contain about a five times higher concentration of $\mathrm{HCl}$ than a coal-fired boiler combustion gas stream because of the low volume of the coal gas. An early estimate by TRW describes $\mathrm{HCl}$ concentrations in coal gas streams to be in the range from 1 to $500 \mathrm{ppm}(\mathrm{TRW}, 1981)$. The actual concentration of $\mathrm{HCl}$ vapor in the coal gas stream will depend on the chlorine content of the coal, the gasification temperature, and the type of gasifier. For example, a Texaco oxygen-blown gasifier that produces a medium-Btu coal gas will have a higher $\mathrm{HCl}$ concentration than a gasifier that produces a low Btu-fuel gas, such as a fluidized-bed gasifier operating in air-blown mode (for example KRW or U-Gas gasifier). Perhaps the most reliable data of $\mathrm{HCl}$ concentration was obtained from the operation of a fixed-bed gasifier at General Electric Corporate Research and Development (GE-CRD) at Schenectady, NY. At that facility, the concentration of $\mathrm{HCl}$ vapor was found to be about $300 \mathrm{ppmv}$ when the gasifier was operated using a coal containing 0.24 wt\% chlorides (Bevan et al., 1994).

\section{Need for HCl Removal in IGCC Power Generation systems}

The high-temperature MCFC is a technology that is being developed for future power generation because of its very high efficiency $(>60 \%)$. However, for sustained and efficient operation of the MCFC, the coal gas must be free of contaminants such as particulate matter, sulfur, and chloride species. Halogen compounds are deleterious to MCFCs because they can lead to severe corrosion of cathode hardware (Kinoshita et al., 1988). $\mathrm{HCl}$ also can react with the molten carbonate electrolyte to form corresponding halides. These halides increase the loss of electrolyte because of the high vapor pressures of $\mathrm{LiCl}$ and $\mathrm{KCl}$. The high vapor pressures of these compounds enhance electrolyte loss. An increase in the cell resistance and a corresponding decrease in the cell voltage were also observed in feed gas containing $1 \mathrm{ppmv} \mathrm{HCl}$ vapor (Pigeaud and Wilemski, 1992). Although the allowable $\mathrm{HCl}$ concentration in a MCFC feed gas was earlier estimated to be less than 1 ppmv (Gillis, 1980), it is now estimated to be less than $0.5 \mathrm{ppmv}$, based on the study conducted by Energy Research Corporation (Hischenhofer, 1994).

The role of $\mathrm{HCl}$ as an impurity in coal gas used to fuel a gas turbine is not well defined. A high acid concentration in itself possesses great potential for destructive corrosion, but in a coal gas containing alkali sulfate species, the presence of $\mathrm{HCl}$ may have the beneficial effect of lowering the concentration of these species in the turbine (Marlow, 1983). No investigations have been reported on the interaction of $\mathrm{HCl}$ with alkali sulfates or their precursors in high-temperature coal gas, and no standards on concentration limits exist. In spite of the absence of specified limits, the removal of $\mathrm{HCl}$ vapor from the fuel must be beneficial for IGCC systems, because the presence of $\mathrm{HCl}$ vapor is generally deleterious to the metal components of the IGCC systems. Perkins et al. 
(1990) report that the chloride deposits found on syngas coolers accelerate the corrosion of the heat exchanger material. $\mathrm{HCl}$ reacts with the deposited slags, forming low-melting iron chlorides, thereby accelerating the corrosion rate.

\section{Need for HCl Removal in Hot Gas Cleanup Systems}

$\mathrm{HCl}$ vapor in the hot coal gas is capable of reacting with the metal oxides present in hot gas desulfurization sorbents. The effect of $\mathrm{HCl}$ vapor on the behavior of zinc ferrite and zinc titanate sorbents has been investigated (Grindley, 1990; Jain and Grindley, 1991). HCl has a significant long-term deteriorating effect on the capacity of zinc ferrite for $\mathrm{H}_{2} \mathrm{~S}$ absorption. For example, during testing of one system, breakthrough time for $\mathrm{H}_{2} \mathrm{~S}$ declined about $60 \%$ in the presence of $1000 \mathrm{ppm} \mathrm{HCl}$ vapor. The chloride vapor appeared to adsorb on or react with both zinc ferrite and zinc titanate sorbents, and the adsorbed chloride species were released during regeneration of the spent sorbent. Limited thermogravimetric analysis (TGA) studies conducted at RTI for Texaco (Gangwal et al., 1990) revealed that chloride was adsorbed on the zinc titanate sorbent surface and subsequently released during regeneration, with very little accumulation of chlorides on the sorbent ( 100 to $200 \mathrm{ppm}$ ). The release of $\mathrm{HCl}$ vapor in the regenerator off-gases may have a deleterious impact on the processing of $\mathrm{SO}_{2}$.

RTI has also evaluated the effect of $\mathrm{HCl}$ on the performance of zinc titanate sorbents in a bench-scale 1-in. ID fluidized-bed reactor (Gupta and O'Brien, 1992). A series of single-cycle and multicycle tests were performed with zinc titanate formulation with two simulated coal gas compositions: a medium Btu gas simulating the Texaco entrained-bed oxygen-blown gasifier and a low-Btu gas simulating an air-blown U-Gas fluidized-bed gasifier. Severe zinc loss was observed with sorbents containing low levels of $\mathrm{TiO}_{2}$. Similarly, in gas streams containing low levels of steam, formation of $\mathrm{ZnCl}_{2}$ was observed at $540^{\circ} \mathrm{C}$.

In the pilot-scale tests conducted at the GE-CRD facility, presence of $\mathrm{HCl}$ caused problems in the hot gas cleanup unit (moving-bed reactor type) using zinc titanate as the desulfurization sorbent. Specifically, during $\mathrm{H}_{2} \mathrm{~S}$ absorption, the chlorides in the coal gas stream adsorbed on the sorbent forming zinc chloride. During the subsequent regeneration, the zinc chloride reacted with $\mathrm{SO}_{2}$ and $\mathrm{O}_{2}$ present in the regeneration recycle gas to form zinc sulfate and deposited on the recycle heat exchanger loops (Bevan et al., 1994). This condition caused blockage of heat exchangers after several days of operation. 


\section{PREVIOUS STUDIES FOR HCI REMOVAL}

A number of processes are available for removing $\mathrm{HCl}$ vapor from industrial and incinerator waste gases. These processes scavenge $\mathrm{HCl}$ by adsorption on activated carbon or alumina or by reaction with alkali or alkaline earth carbonates or oxides. For chemical plants where $\mathrm{HCl}$ must be removed from process feedstocks, commercial chloride guards are marketed by catalyst manufacturers for this application. These materials reduce chloride contaminant levels to $<1 \mathrm{ppm}$, but they require an operating temperature of $<450^{\circ} \mathrm{C}$. Furthermore, these materials cannot be regenerated under realistic conditions.

Largely due to interest during the past decade in the development of coal-fueled MCFC systems, a significant amount of research has been performed to identify and test high-temperature sorbents for $\mathrm{HCl}$. For service at temperatures greater than $500^{\circ} \mathrm{C}$, thermodynamic considerations limit candidate chemical sorbents for sequestering $\mathrm{HCl}$ to alkali and alkaline earth compounds. A 1983 study by Physical Sciences, Inc. (Ham et al., 1984), reported that the alkaline earth chlorides generally have lower vapor pressures than transition- and alkali-metal chlorides, but the partial pressure of $\mathrm{HCl}$ in equilibrium with solid salts is lower for the alkali chlorides than for the alkaline earth chlorides.

Early experimental studies at Physical Sciences, Inc. focused on shortite $\left(\mathrm{Na}_{2} \mathrm{CO}_{3}\right.$. $\left.2 \mathrm{CaCO}_{3}\right)$ and trona $\left(\mathrm{Na}_{2} \mathrm{CO}_{3} \cdot \mathrm{NaHCO}_{3} \cdot 2 \mathrm{H}_{2} \mathrm{O}\right)$ as candidate sorbents (Ham et al., 1984 ). Shortite was reported to react rapidly with $\mathrm{HCl}$ vapor at $523^{\circ} \mathrm{C}$, reducing the coal gas stream $\mathrm{HCl}$ concentration to $1 \mathrm{ppm}$ in a single pass through a fixed bed. Trona exhibited a lower reactivity than shortite, a characteristic that was attributed to sintering of the mineral at the sorption temperature. In another early experimental study on the removal of $\mathrm{HCl}$ vapor from hot coal gas streams, Institute of Gas Technology showed that eutectic melts of $\mathrm{Li}_{2} \mathrm{CO}_{3}$ and $\mathrm{Na}_{2} \mathrm{CO}_{3}$ were capable of reducing $\mathrm{HCl}$ vapor from about $400 \mathrm{ppmv}$ to $<1 \mathrm{ppmv}$ at about $500^{\circ} \mathrm{C}$ (Anderson et al., 1984). The high cost of the sorbent prevented further development of this concept.

Attempts to use flue gas sorbents for chloride removal at elevated temperatures have also been reported. U.S. Bureau of Mines (1967) investigators studying $\mathrm{SO}_{2}$ removal from flue gases reported that alkalized alumina (mainly sodium aluminate) was also effective for chloride removal. More recently, similar compounds sold commercially as chemical process chloride guards have been proposed for flue gas cleanup applications (Katalco Corporation, 1985). At temperatures up to $625^{\circ} \mathrm{C}$, these sorbents can reduce flue gas chloride concentration to less than 1 ppm (Krishnan et al., 1986). 
Battelle Pacific Northwest Laboratories conducted both laboratory- and bench-scale studies to determine the feasibility of simultaneously removing $\mathrm{H}_{2} \mathrm{~S}$ and $\mathrm{HCl}$ in hot coal gas systems by using solid supported molten salts (Lyke, 1985). Using lithium, potassium, and calcium carbonates supported on lithium aluminate, they found that $\mathrm{HCl}$ vapor was reduced from about $200 \mathrm{ppm}$ to $<10 \mathrm{ppm}$ at $800^{\circ} \mathrm{C}$ and $15 \mathrm{~atm}$. The residual chloride in the gaseous effluent consists mainly of alkali chloride vapor whose concentration increased with temperature. An operating cost of about $\$ 0.008 / \mathrm{kWh}(8 \mathrm{mills} / \mathrm{kWh})$ was projected in a preliminary economic analysis.

Laboratory- and bench-scale experiments were performed by SRI International (Krishnan et al., 1986) to evaluate three natural carbonate minerals-nahcolite $\left(\mathrm{NaHCO}_{3}\right)$, shortite, and dawsonite $\left(\mathrm{NaAl}(\mathrm{OH})_{2} \mathrm{CO}_{3}\right)$-as $\mathrm{HCl}$ scavengers for simulated coal gas. A chloride guard (Katalco 59-3) and a commercial flue gas cleanup sorbent (NOXSO) were also examined in the project. All the tested sorbents reacted rapidly with $\mathrm{HCl}$ vapor and reduced the $\mathrm{HCl}$ vapor concentration from about 300 ppmv to about 1 ppmv. The performance of nahcolite was superior in its absorption capacity; the spent sorbent contained up to $54 \mathrm{wt} \%$ chloride. Furthermore, the presence of $\mathrm{H}_{2} \mathrm{~S}$ and trace metal impurities in the coal gas did not significantly affect the performance of the bed for $\mathrm{HCl}$ sorption. An economic evaluation for $\mathrm{HCl}$ cleanup costs in a $100 \mathrm{MW}_{\mathrm{e}}$ plant indicated that the use of nahcolite to remove $\mathrm{HCl}$ vapor would add only about $\$ 0.002 / \mathrm{kWh}(2 \mathrm{mills} / \mathrm{kWh})$ to the cost of the generated electric power.

Several investigators (Walters and Aksoman, 1996; Fusch and Schwerdtfeger, 1996) investigated the use of lime $(\mathrm{CaO})$ for removing $\mathrm{HCl}$ in laboratory-scale reactors at $1 \mathrm{~atm}$. In clean systems containing $\mathrm{HCl}$ and $\mathrm{N}_{2}$, the residual $\mathrm{HCl}$ level was about $20 \mathrm{ppm}$ at $600^{\circ} \mathrm{C}$.

Thermodynamic calculations indicate that with the lime-based system, the equilibrium $\mathrm{HCl}$ level would be about $270 \mathrm{ppm}$ at $400^{\circ} \mathrm{C}$ in gas stream representative of slagging gasifiers. The discrepancy between the calculations and the laboratory test results is likely to be due to the absence of $\mathrm{CO}_{2}$ or $\mathrm{H}_{2} \mathrm{O}$ in the feed gas and lack of high pressure operation.

Thus, alkali-based naturally occurring minerals and synthetic sorbents have been shown in bench-scale experiments to reduce $\mathrm{HCl}$ vapor levels to about $1 \mathrm{ppm}$ in simulated coal gas streams. Most of the studies have focused mainly on the chemical reactivity of the various sorbents and used small laboratory-scale reactors. These studies did not address the preparation of suitable sorbents for commercial-size reactors or the behavior of the sorbents during exposure to coal gas streams from operating coal gasifiers. 


\section{PROGRAM OBJECTIVES}

The objective of this program was to develop alkali-based disposable sorbents capable of reducing $\mathrm{HCl}$ vapor concentrations to less than $1 \mathrm{ppmv}$ in coal gas streams at temperatures in the range from $400^{\circ}$ to $750^{\circ} \mathrm{C}$ and pressures in the range from 1 to $20 \mathrm{~atm}$. The primary areas of focus of this program were investigation of different processes for fabricating the sorbents, testing their suitability for different reactor configurations, obtaining kinetic data, and updating the economics of the process.

The program was divided into the following nine tasks:

1. Information required for National Environmental Policy Act (NEPA)

2. Sorbent preparation and characterization

3. Provision of bench-scale test unit

4. Bench-scale testing

5. Data analysis

6. Pilot-scale production and testing of spray-dried sorbents

7. Characterization of spent sorbents

8. Parametric bench-scale testing

9. Preliminary economic evaluation.

This program was conducted from October 1993 through September, 1999. Initially, three different reactor configurations were considered: fixed-, moving-, and fluidized-bed types. Later, by a technical redirection from DOE/FETC, the moving bed reactor system was given only limited consideration.

This final technical report combines the work performed by SRI International (SRI) and its primary subcontractor, Research Triangle Institute (RTI). SRI performed the studies related to sorbents for fixed-bed reactor studies and RTI focused on sorbents for fluidized-bed reactors. GE$\mathrm{CRD}$, a second subcontractor performed a limited number of studies relating to sorbent development for moving-bed reactor configuration. GE-CRD also performed, at their pilot-scale fixed-bed gasifier facility, testing of spray-dried sorbents provided by RTI. 


\section{SORBENT PREPARATION AND CHARACTERIZATION}

\section{THERMODYNAMIC CONSIDERATIONS}

Equilibrium thermodynamic calculations of alkali compounds and coal gas systems provide a theoretical limit to which chloride vapor level can be reduced under different process conditions. Krishnan et al. (1996) calculated the equilibrium partial pressures of both $\mathrm{HCl}$ and metal chloride vapor as a function of temperatures for various alkali and alkaline earth compounds. These calculations predict the theoretical limit to which the concentration of $\mathrm{HCl}$ can be reduced by various oxide and carbonate sorbents (Table 1). Among the alkali- and alkaline-earth carbonates, only the sodium and potassium compounds have equilibrium $\mathrm{HCl}$ pressures less than $1 \mathrm{ppm}$ at $500^{\circ} \mathrm{C}$. Of the alkali chlorides, potassium system will provide the lowest level of $\mathrm{HCl}$ vapor, but $\mathrm{NaCl}(\mathrm{g})$ has a lower vapor pressure than $\mathrm{KCl}(\mathrm{g})$. The alkaline earth oxides will provide very low equilibrium $\mathrm{HCl}$ vapor levels if they are not converted to corresponding carbonates. But, typical coal gas streams contain $\mathrm{CO}_{2}$ and under thermodynamic equilibrium conditions, the alkaline earth oxides will be converted to the corresponding carbonates.

In addition, the sodium minerals are more abundant than the potassium minerals. Of the alkaline earth compounds considered, only barium compounds have both a low equilibrium $\mathrm{HCl}$ level and a chloride vapor pressure. But the $\mathrm{HCl}$ vapor level in equilibrium with $\mathrm{BaCl}_{2}$ exceeds that in equilibrium with $\mathrm{NaCl}$.

Vaporization of the alkali chlorides depends on temperature, pressure, and gas composition. As the total pressure is increased, the vaporization of chlorides is normally suppressed. Thermodynamic equilibrium calculations indicate that in a gas stream representative of Texaco slagging gasifier, the equilibrium $\mathrm{HCl}$ level would be less than $1 \mathrm{ppm}$ at temperatures below $550^{\circ} \mathrm{C}$ (Figure 1). The combined $\mathrm{HCl}$ and $\mathrm{NaCl}$ vapor levels at $550^{\circ} \mathrm{C}$ in equilibrium with Texaco gasifier gas streams would be less than $1 \mathrm{ppm}$. 
Table 1

\section{EQUILIBRIUM VAPOR PRESSURES OVER ALKALI AND ALKALINE EARTH CHLORIDES}

\begin{tabular}{lllllll} 
& \multicolumn{6}{c}{ Equilibrium Partial Pressure (atm) at } \\
\cline { 2 - 7 } System & \multicolumn{2}{c}{$\mathbf{4 0 0} \mathbf{C}$} & \multicolumn{2}{c}{$\mathbf{5 0 0} \mathbf{C}$} & \multicolumn{2}{c}{$\mathbf{6 0}^{\circ} \mathbf{C}$} \\
\cline { 2 - 7 } $\mathrm{Na}_{2} \mathrm{CO}_{3}$ & $4.3 \times 10^{-8}$ & $1.58 \times 10^{-10}$ & $3.0 \times 10^{-7}$ & $2.7 \times 10^{-8}$ & $1.3 \times 10^{-6}$ & $1.4 \times 10^{-6}$ \\
$\mathrm{~K}_{2} \mathrm{CO}_{3}$ & $2.0 \times 10^{-9}$ & $5.5 \times 10^{-10}$ & $1.9 \times 10^{-8}$ & $7.8 \times 10^{-8}$ & $1.1 \times 10^{-7}$ & $3.4 \times 10^{-6}$ \\
$\mathrm{BaCO}_{3}$ & $2.2 \times 10^{-6}$ & $2.0 \times 10^{-18}$ & $8.3 \times 10^{-6}$ & $6.9 \times 10^{-15}$ & $2.2 \times 10^{-5}$ & $3.5 \times 10^{-12}$ \\
$\mathrm{SrCO}_{3}$ & $2.9 \times 10^{-5}$ & $4.2 \times 10^{-18}$ & $7.1 \times 10^{-5}$ & $1.2 \times 10^{-14}$ & $1.3 \times 10^{-4}$ & $5.4 \times 10^{-12}$ \\
$\mathrm{CaCO}_{3}$ & $2.7 \times 10^{-4}$ & $2.2 \times 10^{-16}$ & $5.5 \times 10^{-4}$ & $3.3 \times 10^{-13}$ & $8.9 \times 10^{-4}$ & $9.2 \times 10^{-11}$ \\
$\mathrm{CaO}$ & $1.8 \times 10^{-9}$ & $2.2 \times 10^{-16}$ & $2.6 \times 10^{-7}$ & $3.3 \times 10^{-13}$ & $1.1 \times 10^{-5}$ & $9.2 \times 10^{-11}$ \\
$\mathrm{BaO}$ & $3.3 \times 10^{-19}$ & $2.0 \times 10^{-18}$ & $9.1 \times 10^{-17}$ & $6.9 \times 10^{-15}$ & $2.5 \times 10^{-13}$ & $3.5 \times 10^{-12}$ \\
$\mathrm{SrO}$ & $2.1 \times 10^{-16}$ & $4.2 \times 10^{-18}$ & $1.5 \times 10^{-12}$ & $1.2 \times 10^{-14}$ & $2.2 \times 10^{-10}$ & $5.4 \times 10^{-12}$ \\
\hline
\end{tabular}

$\mathrm{MCl}_{\mathrm{x}}(\mathrm{g})=$ Corresponding metal chloride vapor with a chloride stoichiometry of $\mathrm{x}$. For Na- and $\mathrm{K}$-based systems, $\mathrm{x}=1$; for $\mathrm{Ba}-$. Ca-, and $\mathrm{Sr}$ - based systems, $\mathrm{x}=2$.

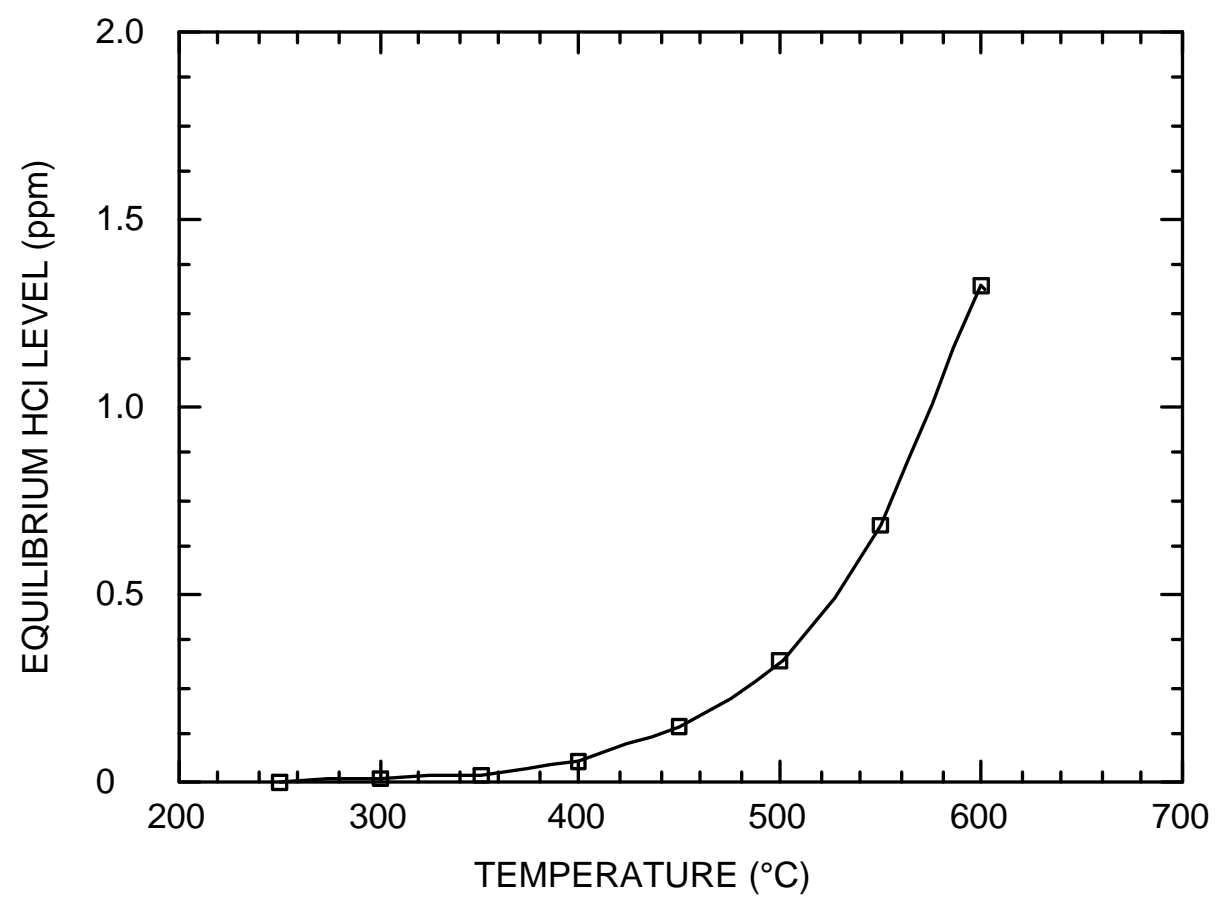

Figure 1. The equilibrium partial pressure of $\mathrm{HCl}$ as a function of temperature at $20 \mathrm{~atm}$ in a Texaco coal gasifier gas stream. 
The thermodynamic stability required for the alkali chlorides to achieve a very low concentration of chloride vapor in the hot coal gas stream prevents regeneration of the sorbent by simple reversal of the absorption reaction. In contrast to the desulfurization sorbents, the $\mathrm{HCl}$ vapor removal sorbents cannot be regenerated by oxidation of the spent sorbent because the chemical stability of alkali chlorides exceeds that of the corresponding oxides or hydroxides:

$$
\begin{array}{lll}
2 \mathrm{NaCl}+0.5 \mathrm{O}_{2}(\mathrm{~g})=\mathrm{Na}_{2} \mathrm{O}+\mathrm{Cl}_{2}(\mathrm{~g}) & \mathrm{K}_{400^{\circ} \mathrm{C}}=2.4 \times 10^{-58} ; & \mathrm{K}_{800^{\circ} \mathrm{C}}=3.4 \times 10^{-35} \\
\mathrm{NaCl}+\mathrm{H}_{2} \mathrm{O}(\mathrm{g})=\mathrm{NaOH}+\mathrm{HCl}(\mathrm{g}) & \mathrm{K}_{400^{\circ} \mathrm{C}}=2.1 \times 10^{-11} ; & \mathrm{K}_{800^{\circ} \mathrm{C}}=7.2 \times 10^{-7}
\end{array}
$$

However, a process scheme in which the alkali chlorides are converted to corresponding sulfates, which are then reduced to the carbonates, is thermochemically feasible:

$$
\begin{array}{ll}
4 \mathrm{NaCl}+2 \mathrm{SO}_{2}+\mathrm{O}_{2}+2 \mathrm{H}_{2} \mathrm{O}=2 \mathrm{Na}_{2} \mathrm{SO}_{4}+4 \mathrm{HCl} & \mathrm{K}_{400^{\circ} \mathrm{C}}=5.8 \times 10^{16} \\
\mathrm{Na}_{2} \mathrm{SO}_{4}+4 \mathrm{H}_{2}+\mathrm{CO}_{2}=\mathrm{Na}_{2} \mathrm{CO}_{3}+\mathrm{H}_{2} \mathrm{~S}+3 \mathrm{H}_{2} \mathrm{O} & \mathrm{K}_{400^{\circ} \mathrm{C}}=8.3 \times 10^{7}
\end{array}
$$

These reactions are thermodynamically feasible, but the kinetics of reaction (3) is slow as determined by the U.S. Bureau of Mines (1967) during regeneration of chloride containing alkalized alumina, a sorbent investigated for the removal of $\mathrm{SO}_{2}$ from flue gas streams. Even assuming that reaction (3) is rapid, disposal of regenerator off-gas presents additional problems because it may contain unreacted $\mathrm{SO}_{2}, \mathrm{HCl}$, and possibly $\mathrm{SO}_{3}$. The surface area and strength of the sorbents may deteriorate significantly because of multiple chemical conversions. Hence, in contrast to regenerable materials, inexpensive and disposable sorbents are needed for $\mathrm{HCl}$ vapor removal. Naturally occurring minerals are less expensive for use as disposable sorbents than synthetic formulations that are sold as chloride guards commercially.

\section{SORBENT SELECTION}

The thermodynamic analysis indicates that a sodium-based system provides the best compromise between the attainable equilibrium level of $\mathrm{HCl}$ vapor and the volatility of the alkali chloride. Sodium-based minerals are more abundant in nature than potassium-based minerals. Carbonate-based minerals are the preferred choice as they do not introduce any undesirable components into the coal gas stream. Hence, sodium carbonate minerals are the primary choice for consideration as $\mathrm{HCl}$ vapor removal sorbents in this study.

From the thermodynamic analysis, the total chloride (both $\mathrm{HCl}$ and $\mathrm{MCl}$ ) vapor appears to be low for barium-based systems, particularly at temperatures above $725^{\circ} \mathrm{C}$. However, the toxicity of barium compounds makes the disposal of the spent sorbents expensive. In the United States, the naturally occurring barium mineral is barium sulfate (barite) and it must be converted to barium 
carbonate for use as a hot coal gas dechlorination sorbent. Naturally occurring barium carbonate mineral (witherite) is found mostly in England. The cost of preparing barium carbonate or other compounds suitable for $\mathrm{HCl}$ removal in the United States would add additional cost to the chloride removal process. The added cost of preparing the sorbent and its disposal makes the barium system unattractive.

\section{OCCURRENCE OF SODIUM CARBONATE MINERALS}

Of the several sodium carbonate minerals occurring in the United States, nahcolite, trona, and shortite are most important. Many locations in the United States contain natural sodium carbonate minerals. However, relatively few of these deposits are large enough for commercial use, are favorably located, or have adequate sodium carbonate content. The Searles Lake and Owens Lake areas in California and the Green River Formation in Wyoming have been the major sources for commercial soda ash production. Currently, about $90 \%$ of the soda ash production in the United States takes place in Wyoming.

Several sodium carbonate minerals occur in the Green River Formation in Wyoming, Utah, and Colorado (Fahey, 1962). Shortite $\left(\mathrm{Na}_{2} \mathrm{CO}_{3} \cdot 2 \mathrm{CaCO}_{3}\right)$, trona $\left(\mathrm{Na}_{2} \mathrm{CO}_{3} \cdot \mathrm{NaHCO}_{3} \cdot 2 \mathrm{H}_{2} \mathrm{O}\right)$, nahcolite $\left(\mathrm{NaHCO}_{3}\right)$, pirssonite $\left(\mathrm{Na}_{2} \mathrm{CO}_{3} \cdot \mathrm{CaCO}_{3} \cdot 2 \mathrm{H}_{2} \mathrm{O}\right)$, gaylussite $\left(\mathrm{Na}_{2} \mathrm{CO}_{3} \cdot \mathrm{CaCO}_{3} \cdot 5 \mathrm{H}_{2} \mathrm{O}\right)$, dawsonite $\left(\mathrm{NaAl}(\mathrm{OH})_{2} \mathrm{CO}_{3}\right)$, northupite $\left(\mathrm{Na}_{2} \mathrm{CO}_{3} \mathrm{MgCO} \mathrm{CaCl}_{2}\right)$ and bradleyite $\left(\mathrm{Na}_{3} \mathrm{PO}_{4} \mathrm{MgCO}_{3}\right)$ are known to occur in large quantities in the Green River Formation. Of these, northupite and bradleyite are not suitable as chloride removal sorbents because of their chloride or phosphate content. Shortite, nahcolite, dawsonite, and trona are more abundant than the other minerals.

Approximately 30 billion tons of nahcolite occur in the Piceance Creek Basin of northwestern Colorado (Farris and Mains, 1978). Of these, 17.5 billion tons can be mined economically. Nahcolite occurs generally both as minable beds and disseminated nodules in the shale. The mineral can be recovered directly from selected deposits or by physical such as grinding and froth flotation. In-situ mining is also feasible. Previous studies at SRI have shown that nahcolite is the superior sorbent compared to other sodium-containing minerals (Krishnan et al., 1986).

In contrast to nahcolite, dawsonite occurs as fine crystals, $5 \mu \mathrm{m}$ or less in size, disseminated throughout the organic phase of the oil shale beds. The mineral is recoverable by dissolution in aqueous solution. Alternatively, it can be recovered after low-temperature retorting of the shale for shale oil production. It is estimated that approximately 27 billion tons of dawsonite occur in the Piceance Creek Basin, and about 10 billion tons are recoverable if shale oil production 
is practiced commercially (Farris and Mains, 1978). Dawsonite is also synthesized as dihydroxy sodium aluminum carbonate (DSAC) for use as an antacid and as a chemical reagent.

About 125 million tons of shortite mineral are estimated to be present per square mile in southwestern Wyoming. Currently, shortite is mined along with trona and is rejected in the insoluble portion during the manufacture of soda ash. At present, there is no viable market for shortite. In one commercial operation, it is etimated that 0.12 million tons of shortite are rejected every year and that the reserves would last more than 100 years. Shortite can be separated from the gangue minerals either by selective grinding or by froth flotation.

Shortite is a dense and crystalline mineral, and thus its practical $\mathrm{HCl}$ absorption capacity is only a small fraction (about 8\%) of its theoretical capacity. The difficulty of separating the shortite mineral from oil shale deposits with which it is associated also makes shortite mineral as a secondary choice. If the shortite is not completely separated from the oil shale, sulfur compounds from the shale will release $\mathrm{H}_{2} \mathrm{~S}$ into the hot coal gas stream.

\section{REACTIVITY OF NAHCOLITE POWDER}

Based on the above considerations and previous experimental studies, nahcolite mineral was selected as the material of choice for preparing $\mathrm{HCl}$ removal sorbent formulations. Initially, about $60 \mathrm{~kg}$ of nahcolite powder was obtained from NaTec Resources, Inc., Houston, TX. Sodium bicarbonate $\left(\mathrm{NaHCO}_{3}\right)$ was the main component of the nahcolite. Thermogravimetric experiments conducted at RTI showed that the bicarbonate rapidly decomposes and reacts with $\mathrm{HCl}$ at temperatures above $450^{\circ} \mathrm{C}$ (Figure 2).

Initial weight loss shown in Figure 2 corresponds to the decomposition of $\mathrm{NaHCO}_{3}$ to $\mathrm{Na}_{2} \mathrm{CO}_{3}$. After the decomposition of the bicarbonate is complete, the sorbent reacts with $\mathrm{HCl}$ to form $\mathrm{NaCl}$ resulting in a weight gain. Stoichiometric calculations show that the decomposition reaction will lead to a weight loss corresponding to a weight fraction of 0.631 and the complete conversion of $\mathrm{Na}_{2} \mathrm{CO}_{3}$ to $\mathrm{NaCl}$ will result in a final weight fraction of 0.696 .

The nahcolite powder was heated at $300^{\circ}, 400^{\circ}$, and $500^{\circ} \mathrm{C}$ for $16 \mathrm{~h}$ to determine the changes in surface area as a function of temperature. The surface area of the powder decreased from its original value of $12 \mathrm{~m}^{2} / \mathrm{g}$ to less than $1 \mathrm{~m}^{2} / \mathrm{g}$ at $500^{\circ} \mathrm{C}$ (Table 2). These observations indicated that a binder is needed to prevent excessive sintering of the sorbent. 


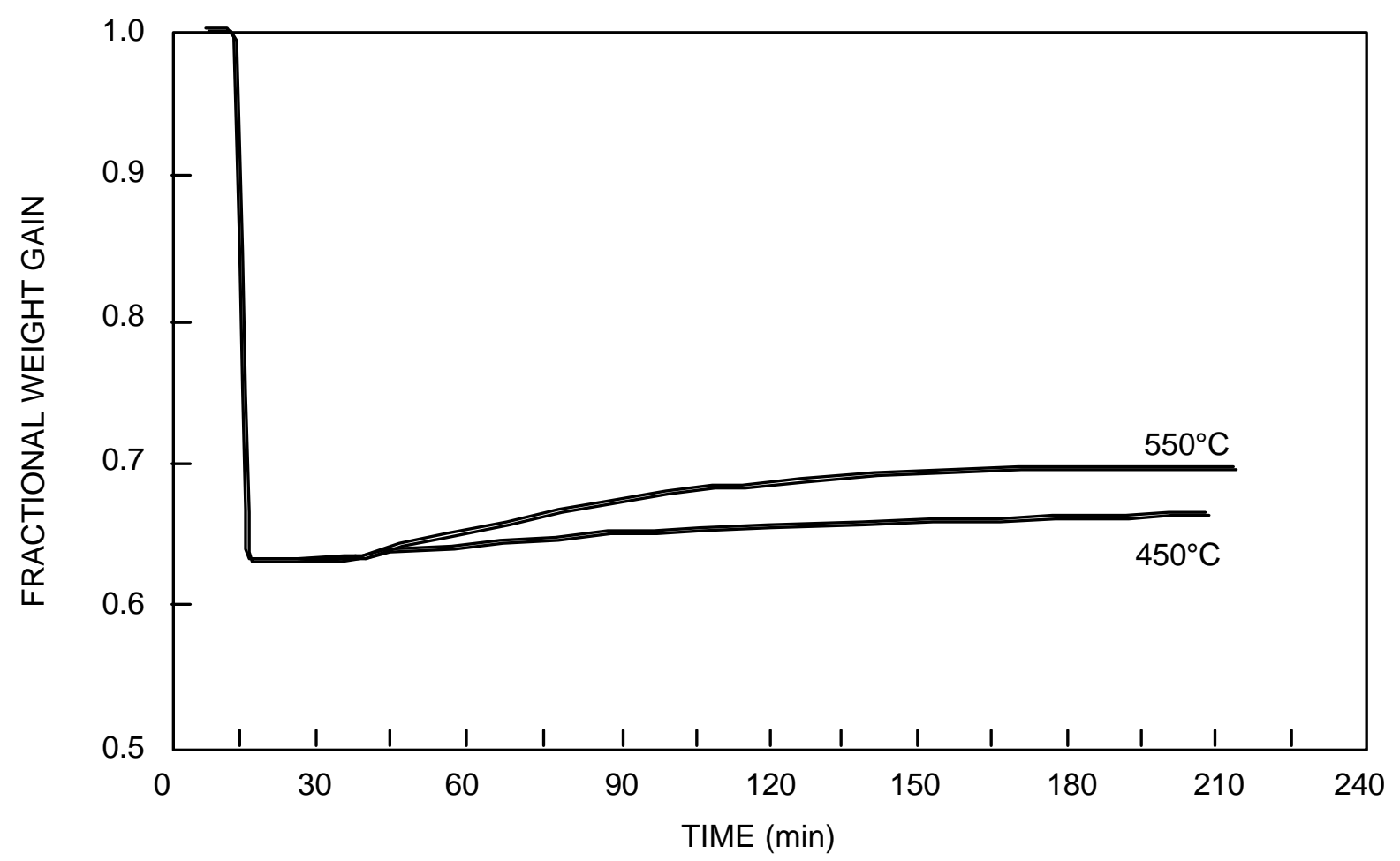

Figure 2. The reactivity of nahcolite powder with $1750 \mathrm{ppm} \mathrm{HCl}$ vapor in nitrogen.

Table 2

\section{CHANGES IN SURFACE AREA OF NAHCOLITE POWDER WITH TEMPERATURE}

$\underline{\text { Temperature }\left({ }^{\circ} \mathbf{C}\right)}$

25

300

400

500
Surface Area $\left(\mathbf{m}^{2} / \mathbf{g}\right)$

12.0

4.7

1.7

0.7 


\section{FABRICATION AND CHARACTERIZATION OF THE SORBENT PELLETS}

\section{Fabrication of the Sorbent Pellets}

The removal of $\mathrm{HCl}$ vapor from hot coal gas streams can be accomplished in several reactor configurations. Fixed-, moving-, and fluidized-bed reactors are being developed for hot coal desulfurization, and similar reactors can be used for chloride removal. Fixed-bed reactors are used extensively in the chemical and metallurgical industries and are relatively simple in design, but batch in operation, if the sorbent needs to be changed or regenerated. Several reactors are needed in a plant for uninterrupted operation. The sorbent pellets must have adequate crush strength to withstand the compressive stresses on them throughout their service duration. Sorbents in the fixed-bed reactors are, typically, in the shape of spheres, cylindrical extrudates, or elliptical pellets. Because the residence time of the sorbent bed is relatively long, full sorbent utilization is feasible and hence high chloride capacity could be achieved. Pellets of these types could be fabricated by extrusion, briquetting, or disc pelletizing. All these methods are widely used to fabricate catalysts, minerals, and other agglomerates.

About $5 \mathrm{~kg}$ of nahcolite powder was agglomerated into spheres of about $5 \mathrm{~mm}$ in diameter using a disc pelletizer by Ferro-Tech Corporation, Wyandotte, MI. These pellets were made with $10 \%$ bentonite as a binder in a disc pelletizer. About 15 types of sorbent pellets, each batch about $4 \mathrm{~kg}$, were made by extrusion using pilot-scale extruder (EXDFS 1000) and other facilities available at the LCI Corporation, Charlotte, NC. These pellets contained various amounts of bentonite or sodium silicate binders and methocel pore forming agent. They were extruded into cylinders of 1.5, 2, 3, and $5 \mathrm{~mm}$ diameter using a pilot-scale extruder. Some of the cylinderical pellets were also rounded off using a spinning disc called "Marumurizer." Table 3 lists the parameters used in the preparation of these pellets.

\section{Physical Properties of the Pellets}

The surface areas of spherical pellets calcined for $4 \mathrm{~h}$ were measured by the BET technique. As expected, the surface area decreased as the calcination temperature was increased (Table 4). The crush strength of the pellets made in the disc pelletizer was only about 20 to $30 \%$ of those made by extrusion, mainly because of very little compressive force could be applied to the pellets in a disc pelletizer. Initially, particles were attracted by capillary action of the binder solution and the pellet strength was developed later by the binder during drying and calcining. In contrast, high compressive forces applied during extrusion led to the development of strong pellets. 
Table 3

PELLET PROCESSING PARAMETERS DURING EXTRUSION ${ }^{1}$

\begin{tabular}{lccccc}
$\begin{array}{c}\text { Batch } \\
\text { Number }\end{array}$ & $\begin{array}{c}\text { Diameter } \\
(\mathbf{m m})\end{array}$ & $\begin{array}{c}\text { Bentonite } \\
(\mathbf{g m})\end{array}$ & $\begin{array}{c}\text { Sodium Silicate } \\
(\mathbf{g m})\end{array}$ & $\begin{array}{c}\text { Water } \\
(\mathbf{g m})\end{array}$ & $\begin{array}{c}\text { Methocel }^{2} \\
(\mathbf{m l})\end{array}$ \\
\hline L-01 & 5 & 400 & - & & 700 \\
L-03 & 2 & 400 & - & 700 \\
L-04 & 2 & 400 & - & & 750 \\
L-06 & 5 & 400 & - & & 970 \\
L-07 & 3 & 400 & - & & 967 \\
L-08 & 1.5 & 400 & - & 150 & 730 \\
L-09 & 3 & - & 80 & 350 & 470 \\
L-10 & 3 & - & 80 & 800 & - \\
L-11 & 3 & 400 & - & 700 & - \\
L-12 & 3 & 400 & - & & \\
\hline
\end{tabular}

${ }^{1}$ Each batch used $4 \mathrm{~kg}$ of nahcolite powder.

${ }^{2}$ Methocel was added as a $6 \%$ solution in water.

Table 4

SURFACE AREA OF NAHCOLITE PELLETS MADE BY DISC PELLETIZATION AS A FUNCTION OF TEMPERATURE

\begin{tabular}{ccc} 
Temperature $\left({ }^{\circ} \mathbf{C}\right)$ & Weight Loss $(\%)$ & Surface area $\left(\mathbf{m}^{2} / \mathbf{g}\right)$ \\
\cline { 2 - 3 } 150 & - & 10.15 \\
300 & 33.9 & 4.74 \\
400 & 34.8 & 1.69 \\
500 & 38.4 & 0.97 \\
600 & 42.0 & 0.82
\end{tabular}


The pellets fabricated by extrusion at LCI Corporation were dried in an oven at about $120^{\circ} \mathrm{C}$ for about $8 \mathrm{~h}$. After drying, the surface areas of two of the pellet formulations were higher than others by a factor of 2 . The pellet formulations were calcined for $16 \mathrm{~h}$ at $300^{\circ}, 400^{\circ}, 500^{\circ}$, and $600^{\circ} \mathrm{C}$. The surface area declined as the calcination temperature increased (Figure 3). The differences in the type and amount of the binders, pellet diameter, or processing conditions did not significantly affect the surface area of calcined pellets.

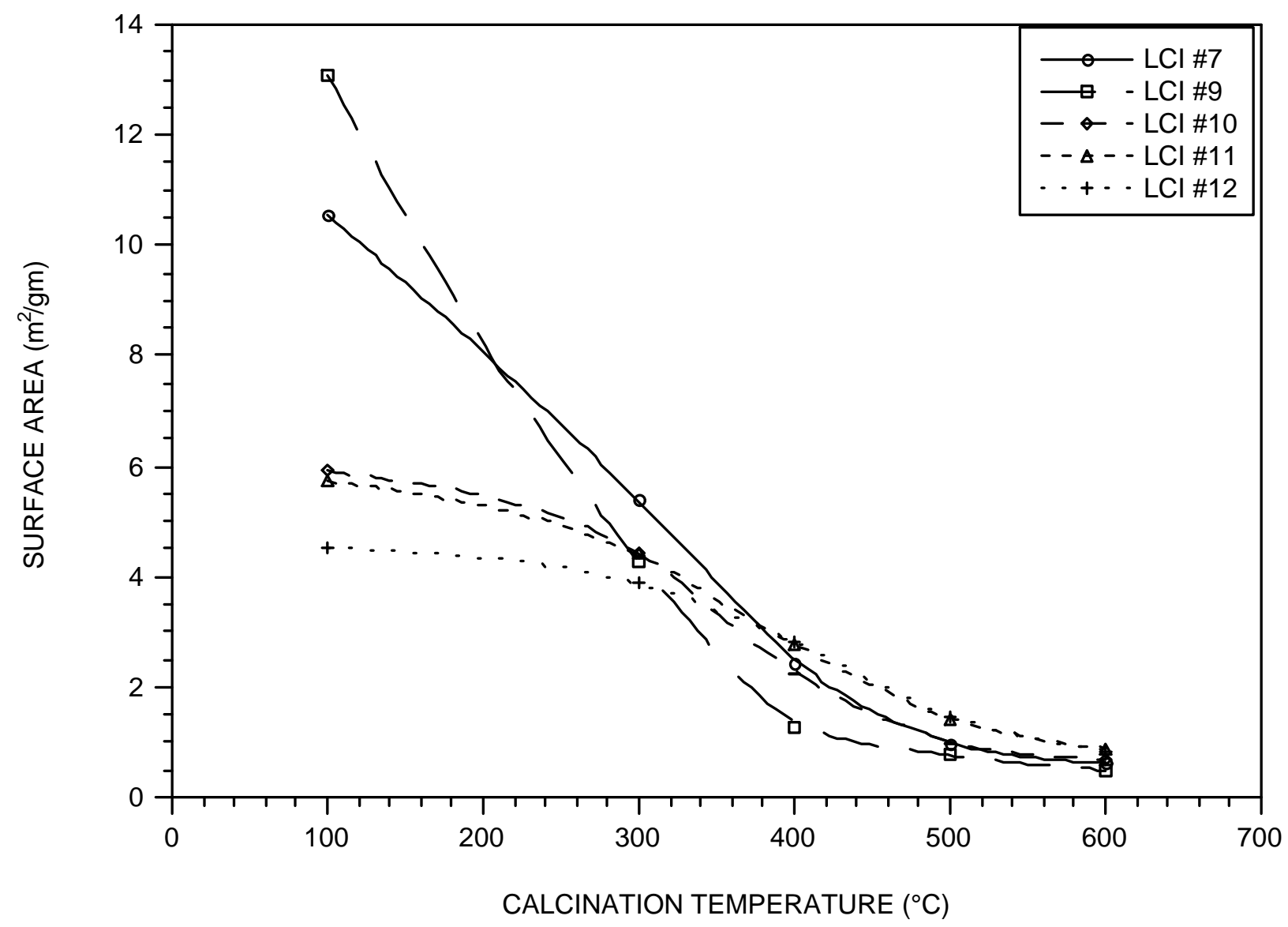

Figure 3. The surface area of extruded pellets as a function of temperature.

Mercury porosimetry was used to determine the pore size distribution of L-7, L-10, and $\mathrm{L}-12$ pellets after calcination at $500^{\circ} \mathrm{C}$ for $4 \mathrm{~h}$. The results shown in Figure 4 indicate that the L07 and L-10 pellets were more porous than L-12 pellets. L-12 pellets were made with a significant amount of water addition during pelletization, which could have lowered its porosity. The binder did not appear to have a significant effect on the porosity, because L-07 and L-12 were made with bentonite and sodium silicate binders, respectively. 


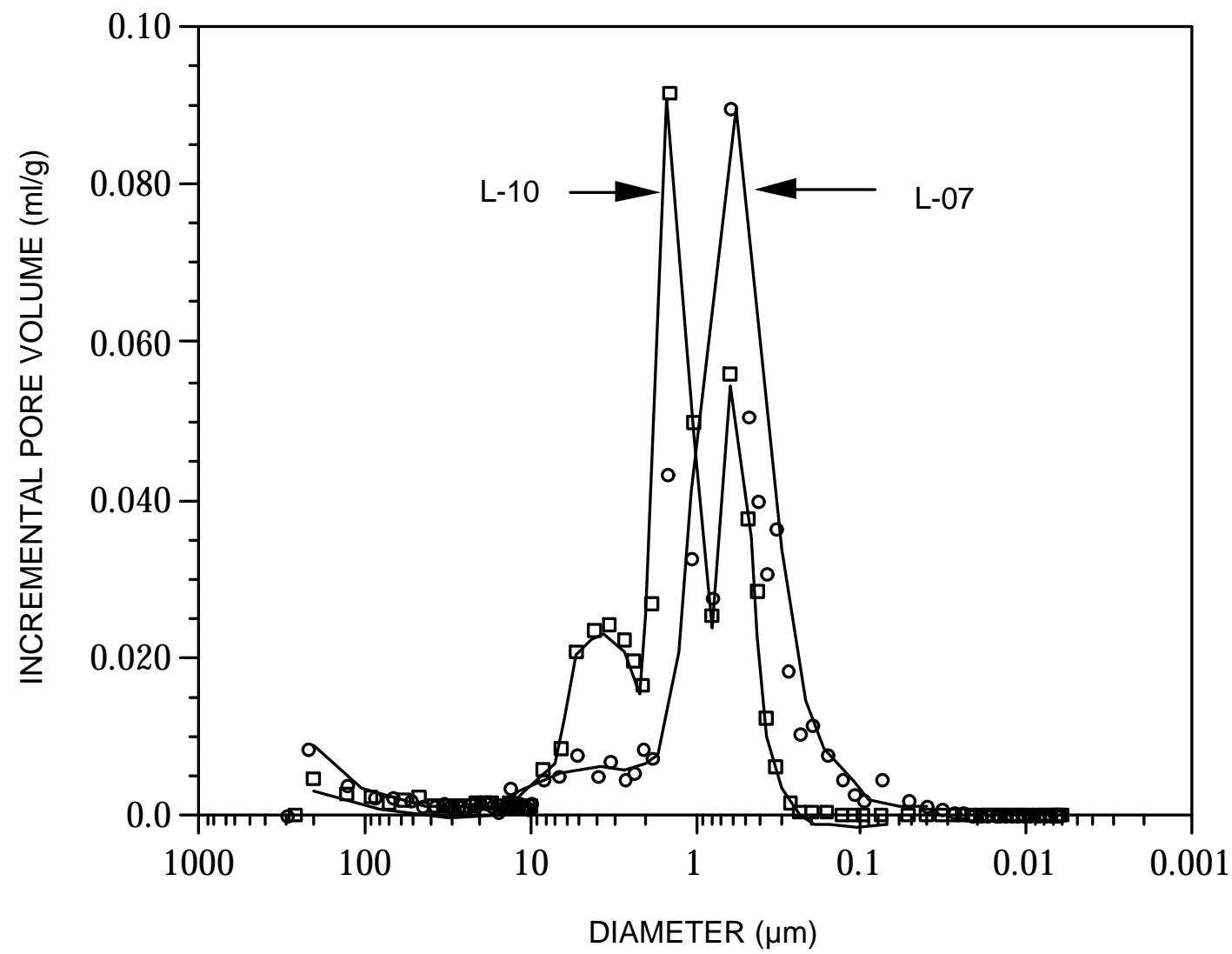

Figure 4. The pore size distribution of nahcolite pellets with bentonite (L-07) and sodium silicate (L-10) as binders.

Pore size distribution measurements were also performed with the nahcolite pellets exposed to simulated coal gas streams containing $\mathrm{HCl}$ vapor at $400^{\circ}$ and $600^{\circ} \mathrm{C}$ (Figures 5 and 6). These sorbents were from bench-scale tests with 15 -cm-deep beds. The pore size distribution measurements showed that pore growth had occurred at $600^{\circ} \mathrm{C}$; majority of the pores in the pellets exposed at $400^{\circ} \mathrm{C}$ were in the range from 0.5 to $5 \mu \mathrm{m}$ whereas those exposed at $600^{\circ} \mathrm{C}$ had pores in the range from 1 to $10 \mu \mathrm{m}$. No significant differences were observed in the pore size distribution between upstream and downstream ends of the bed.

The crush strength of the pellets made by extrusion were measured by the ASTM D-4179 method. Table 5 lists the observed crush strength for pellets calcined at $300^{\circ} \mathrm{C}$ for $16 \mathrm{~h}$. These crush strength values should be compared to a $646 \mathrm{~kg} / \mathrm{m}$ observed for the catalyst grade zinc oxide extrudates (for example, G-72D material sold by United Catalyst Inc.) used in commercial desulfurization processes in the petroleum industry. 


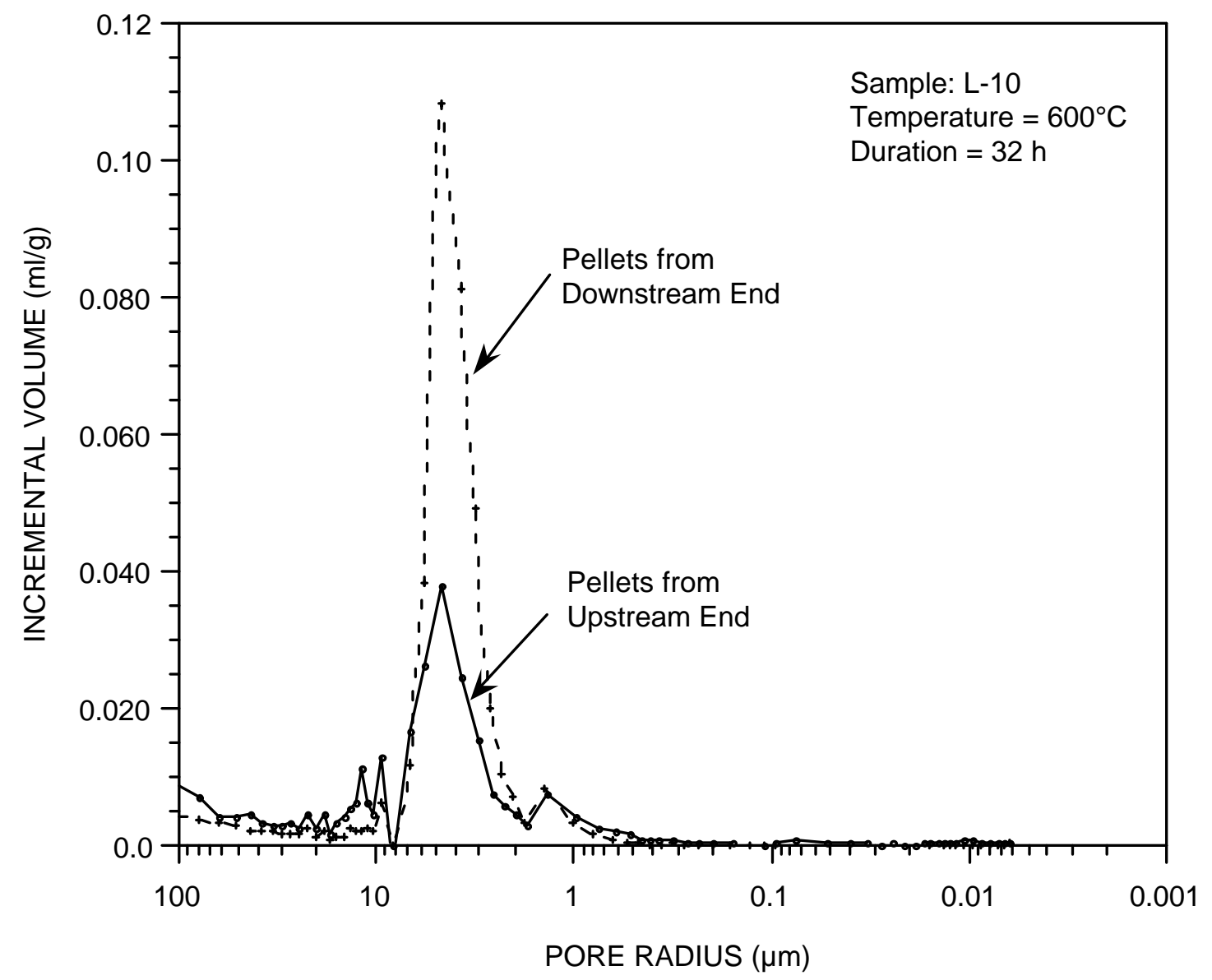

Figure 5. Pore size distribution of spent sorbents after reaction at $400^{\circ} \mathrm{C}$ for $32 \mathrm{~h}$. 


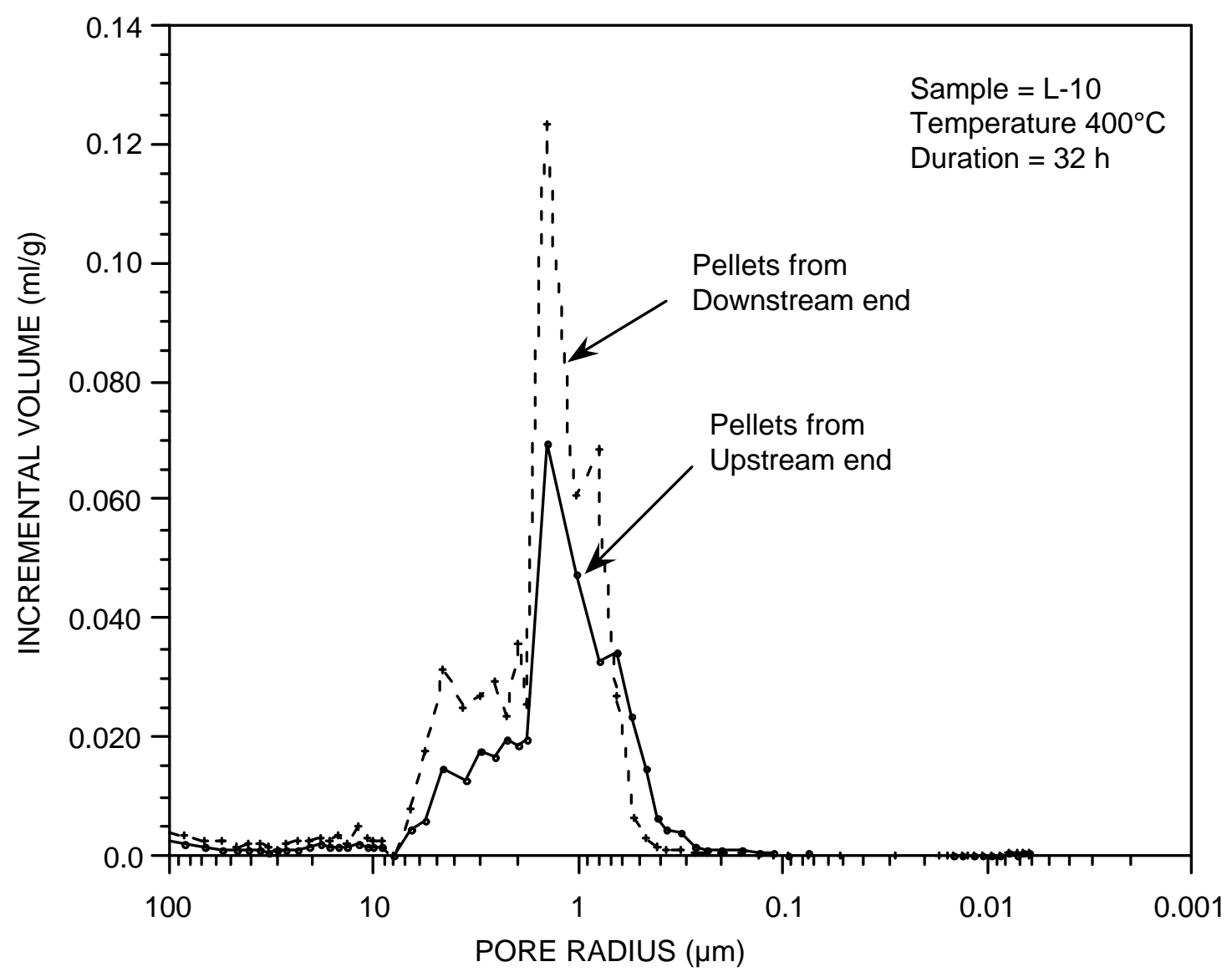

Figure 6. Pore size distribution of spent sorbents after reaction at $600^{\circ} \mathrm{C}$ for $32 \mathrm{~h}$. 
Table 5

\section{CRUSH STRENGTH OF EXTRUDED PELLETS CALCINED AT $300^{\circ} \mathrm{C}$}

\begin{tabular}{cc} 
Batch & Crush Strength $(\mathbf{k g} / \mathbf{m})$ \\
\hline L-07 & 386.9 \\
L-09 & 415.2 \\
L-10 & 537.0 \\
\hline
\end{tabular}

As shown in Table 6, the calcined and spent sorbents were analyzed by mercury porosimetry for the pore size distribution and porosity. No significant differences in the surface area or the pore size distribution were found between the pellets made with bentonite and sodium silicate as the binder. A decrease in the pore volume was observed in the spent sorbent made with bentonite binder.

Table 6

SOME PHYSICAL PROPERTIES OF PELLETIZED SORBENTS

\begin{tabular}{|c|c|c|c|c|}
\hline \multirow[b]{2}{*}{ Parameter } & \multicolumn{2}{|c|}{ L-10 ${ }^{1}$} & \multicolumn{2}{|c|}{${\mathrm{L}-07^{1}}^{1}$} \\
\hline & Calcined $^{3}$ & Spent $^{4}$ & Calcined $^{3}$ & Spent $^{4}$ \\
\hline Surface area $\left(\mathrm{m}^{2} / \mathrm{g}\right)$ & 1.0 & 0.4 & 1.0 & 1.8 \\
\hline Bulk density $\left(\mathrm{g} / \mathrm{cm}^{3}\right)$ & 1.1 & 1.3 & 1.0 & 1.2 \\
\hline Skeletal density $\left(\mathrm{g} / \mathrm{cm}^{3}\right)$ & 2.4 & 2.1 & 2.3 & 1.9 \\
\hline Pore volume $\left(\mathrm{cm}^{3} / \mathrm{g}\right)$ & 0.29 & 0.30 & 0.52 & 0.27 \\
\hline Average Pore Dia. $(\mu \mathrm{m})$ & 1.0 & 0.24 & 0.56 & 0.36 \\
\hline Porosity (\%) & 54.9 & 38.2 & 54.0 & 33.4 \\
\hline
\end{tabular}

1 L-10: 3-mm dia. extrudate; 5\% sodium silicate + methocel.

L-07: 3-mm dia. extrudate; $10 \%$ bentonite + methocel.

Calcined at $500^{\circ} \mathrm{C}$ for $4 \mathrm{~h}$.

4 Exposed to $1500 \mathrm{ppm} \mathrm{HCl}$ at $550^{\circ} \mathrm{C}$ for $24 \mathrm{~h}$ in a fixed-bed reactor.

5 Surface area calculated from the mercury porosimetry data. 
The crush strengths of calcined and reacted pellets were determined (Table 7). The pellets prepared with bentonite and sodium silicate binders had similar strength. The addition of methocel decreased the strength slightly. The crush strength did not change significantly with the extent of reaction with $\mathrm{HCl}$ vapor at $550^{\circ} \mathrm{C}$. A small increase in crush strength was observed with increased exposure to $\mathrm{HCl}$, but this may have been due to increased residence time at the high temperature.

\section{Table 7}

\section{CRUSH STRENGTH OF CALCINED AND REACTED NAHCOLITE PELLETS ${ }^{1}$ AT $550^{\circ} \mathrm{C}$}

\begin{tabular}{|c|c|c|c|c|c|}
\hline \multirow[b]{3}{*}{ Batch No. } & \multirow[b]{3}{*}{ Description } & \multicolumn{4}{|c|}{ Crush Strength $(\mathrm{kg} / \mathrm{m})^{2}$} \\
\hline & & \multirow[b]{2}{*}{ Calcined $^{4}$} & \multicolumn{3}{|c|}{ After Reaction with $\mathrm{HCl}$ Vapor for ${ }^{3}$} \\
\hline & & & $16 \mathrm{~h}$ & $24 \mathrm{~h}$ & 32 h \\
\hline L-07 & $\begin{array}{l}10 \% \text { bentonite }+ \\
\text { methocel }\end{array}$ & 368 & 388 & 425 & 626 \\
\hline L-09 & $\begin{array}{l}2 \% \text { sodium silicate }+ \\
\text { methocel }\end{array}$ & 322 & 488 & 591 & 518 \\
\hline L-10 & $\begin{array}{l}5 \% \text { sodium silicate }+ \\
\text { methocel }\end{array}$ & 390 & 522 & 591 & 518 \\
\hline L-11 & $10 \%$ bentonite & 523 & 947 & 807 & 816 \\
\hline L-12 & $10 \%$ bentonite & 611 & 798 & 1023 & 820 \\
\hline
\end{tabular}

Average diameter and length of the pellets were 0.3 and $0.5 \mathrm{~cm}$, respectively.

2 Crush strength ( $\mathrm{kg}$ load $/ \mathrm{m}$ of the extrudate length) was determined by ASTM D 4179 method.

3 Reacted with $1500 \mathrm{ppm} \mathrm{HCl}$ vapor in a simulated Texaco coal gas stream at $550^{\circ} \mathrm{C}$ for the specified hours.

4 Calcined in air at $550^{\circ} \mathrm{C}$ for $16 \mathrm{~h}$. 
A second set of $40 \mathrm{~kg}$ of nahcolite pellets (L-20 series) with $10 \%$ bentonite binder was prepared also at the LCI Corporation, Charlotte, NC using a different type of extruder (KAHL 14175 Pellet Press). The KAHL press used for extrusion had a stainless steel roller to force the powder through multi-hole die $(1.3 \mathrm{~cm}$ thick) with a rotating blade cutting the extrudates to an uniform length. The pellets made using this device were uniform in dimension and had a nearly twice the crush strength $(650 \mathrm{~kg} / \mathrm{m})$ than the L-07 pellets. The analysis of pellets calcined at $500^{\circ} \mathrm{C}$ for $4 \mathrm{~h}$ showed that the average pore diameter $(0.36 \mu \mathrm{m})$, pore volume $(0.44 \mathrm{cc} / \mathrm{g})$, and porosity $(50.8 \%)$ of L-26 were similar to those of calcined L-07 pellets. The pore size distribution of calcined L-26 pellets are shown in Figure 7.

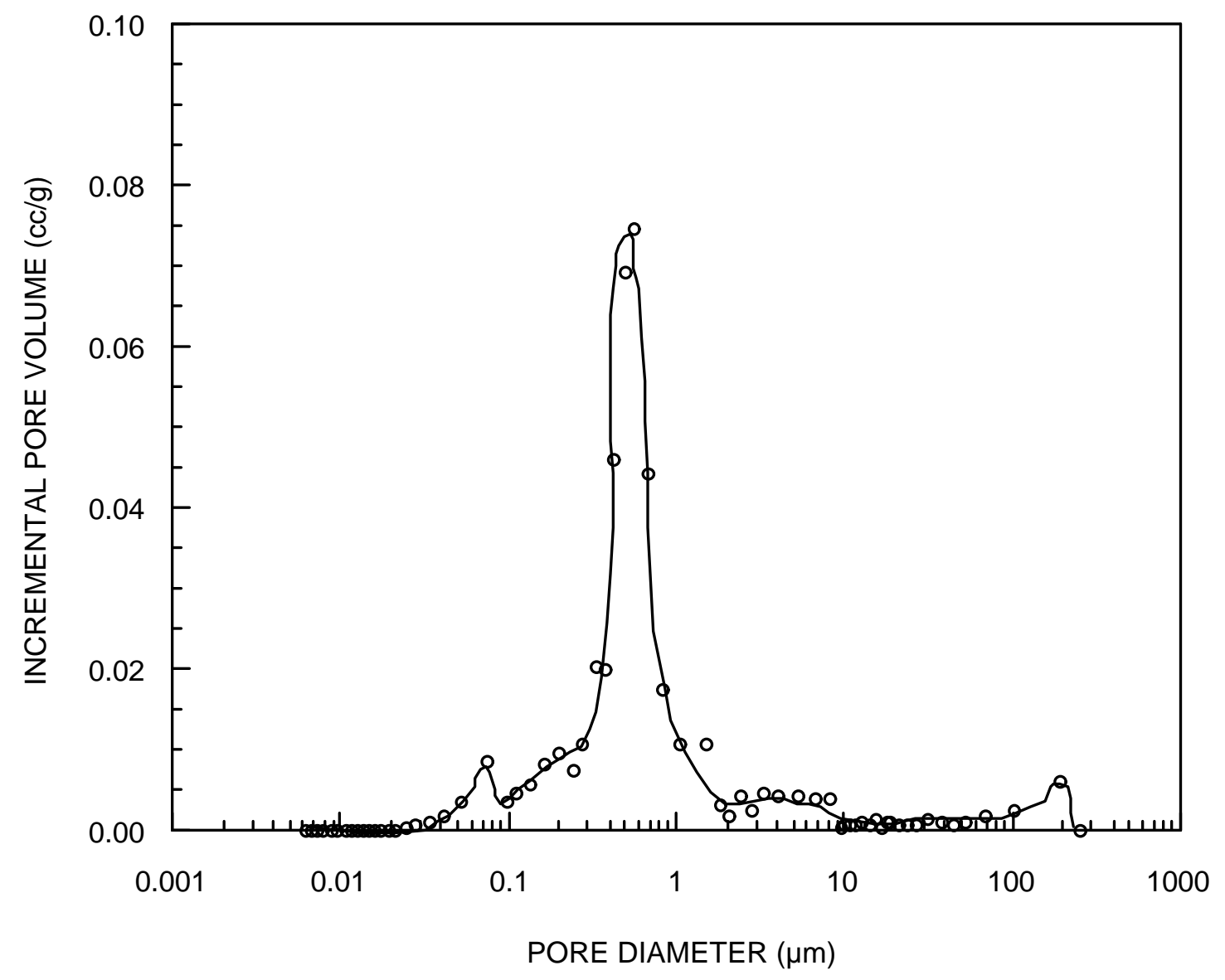

Figure 7. Pore size distribution of pellets made by a pellets press after calcination at $500^{\circ} \mathrm{C}$ for $4 \mathrm{~h}$. 


\section{Reactivities of the Extruded Pellets for HCl Absorption}

The reactivities of six nahcolite sorbent formulations for $\mathrm{HCl}$ vapor at $550^{\circ} \mathrm{C}$ were determined in a differential reactor. In this test, about $4 \mathrm{~g}$ of the sorbent pellets were placed in a compartmented quartz tray situated inside a quartz reactor. A simulated coal gas representative of Texaco oxygen-blown gasifier containing $1500 \mathrm{ppm} \mathrm{HCl}$ vapor was passed through the sorbent pellets at a flow rate of about 4.6 standard liters per minute (SLM). The pellets were analyzed for their chloride content after exposure for $0.5,1,4,8,16,24$, and $32 \mathrm{~h}$. This analysis was performed by dissolving the reacted pellets in water and analyzing the dissolved chloride concentration by ion chromatography. Because about ten pellets were used per sample in each test, variations in the characteristics of individual pellets were averaged.

Because of small quantities of the sorbent pellets and high flow rate of gas, the quantity of $\mathrm{HCl}$ consumed was relatively small and all the pellets were assumed to have been exposed to nearly identical concentration of $\mathrm{HCl}$ vapor (differential reactor). This method is in contrast to the use of a deep bed of sorbent where the concentration of $\mathrm{HCl}$ could change within the bed (integral reactor). By determining the chloride content of the pellets, only $\mathrm{HCl}$ specific reaction rate was measured. The differential reactor method avoids assumptions inherent in thermo-gravimetry, where mass changes must be correlated to specific reactions.

The amounts of chloride accumulated on different sorbent formulations as a function of time at $450^{\circ}$ and $550^{\circ} \mathrm{C}$ are shown in Tables 8 and 9 . Greater than $90 \%$ conversion of the sodium carbonate to sodium chloride was possible with two sorbents (L-07 and L-10) at $550^{\circ} \mathrm{C}$. The sorbents prepared with sodium silicate as a binder exhibited a higher chloride capacity than those prepared with bentonite binder. This result could be attributed to the reaction of sodium silicate with $\mathrm{HCl}$ to form $\mathrm{NaCl}$ :

$$
\mathrm{Na}_{2} \mathrm{SiO}_{3}+2 \mathrm{HCl}(\mathrm{g})=2 \mathrm{NaCl}+\mathrm{SiO}_{2}+\mathrm{H}_{2} \mathrm{O}(\mathrm{g})
$$

Bentonite, an aluminosilicate clay type mineral, does not contain any significant fraction of alkali oxides to react with $\mathrm{HCl}$ in the hot coal gas. Hence, the sorbents made with bentonite binder could be expected to have a lower chloride capacity than those made with sodium silicate binder. 
Table 8

CHLORIDE UPTAKE BY VARIOUS FIXED-BED REACTOR SORBENTS AS A FUNCTION OF EXPOSURE TIME AT $450^{\circ} \mathrm{C}$

\begin{tabular}{crrrrrr} 
& \multicolumn{6}{c}{ Chloride Uptake by the Sorbent Pellets (wt\%) } \\
\cline { 2 - 7 } Time(h) & L-07 & L-09 & L-10 & L-11 & FT $^{\mathbf{1}}$ & SRI $^{\mathbf{2}}$ \\
\hline 0.5 & 0.2 & 0.2 & 0.3 & 0.1 & 0.39 & 0.5 \\
1 & 1.5 & 5.3 & 1.8 & 4.4 & 2.4 & 0.3 \\
4 & 2.7 & 2.5 & 2.2 & 5.5 & 1.7 & 3.7 \\
8 & 5.9 & 10.1 & 7.6 & 9.9 & 9.4 & 8.2 \\
16 & 6.2 & 13.1 & 9.8 & 13.8 & 6.9 & 16.0 \\
24 & 18.9 & 26.9 & 37.0 & 32.5 & 32.0 & - \\
32 & 51.1 & 44.8 & 63.6 & 45.6 & 40.0 & 46.4
\end{tabular}

${ }^{1}$ Spherical pellets made with a disc pelletizer at Ferro-Tech Corporation.

${ }^{2}$ Extruded pellets made at SRI during a previous study (Krishnan et al., 1986).

Table 9

\section{CHLORIDE UPTAKE BY VARIOUS FIXED-BED REACTOR SORBENTS AS A FUNCTION OF EXPOSURE TIME AT $550^{\circ} \mathrm{C}$}

Chloride Uptake by the Sorbent Pellets (wt\%)

\begin{tabular}{rrrrr}
\cline { 2 - 5 } Time (h) & \multicolumn{1}{c}{ L-07 } & \multicolumn{1}{c}{ L-09 } & L-10 & L-11 \\
\hline 0.5 & 1.4 & 1.0 & 0.9 & $<0.1$ \\
1 & $<0.1$ & $<0.1$ & $<0.1$ & $<0.1$ \\
4 & 5.6 & 7.3 & 5.6 & 3.7 \\
8 & 15.0 & 22.0 & 23.0 & 14.0 \\
24 & 29.0 & 29.0 & 44.0 & 39.0 \\
32 & 32.0 & 37.0 & 61.0 & 34.0 \\
\hline
\end{tabular}


As shown in Figures 8 and 9, no major difference exists in the initial reactivity of different formulations. The chloride uptake by the pellets made with bentonite as a binder are nearly similar. As explained previously, the pellets made with sodium silicate binder exhibited a higher chloride uptake. Comparison of the data at $450^{\circ}$ and $550^{\circ} \mathrm{C}$ indicate that the final chloride uptake values may be slightly lower at the higher temperature. However, the differences are small and may be attributed to a small number of pellets used in each test.

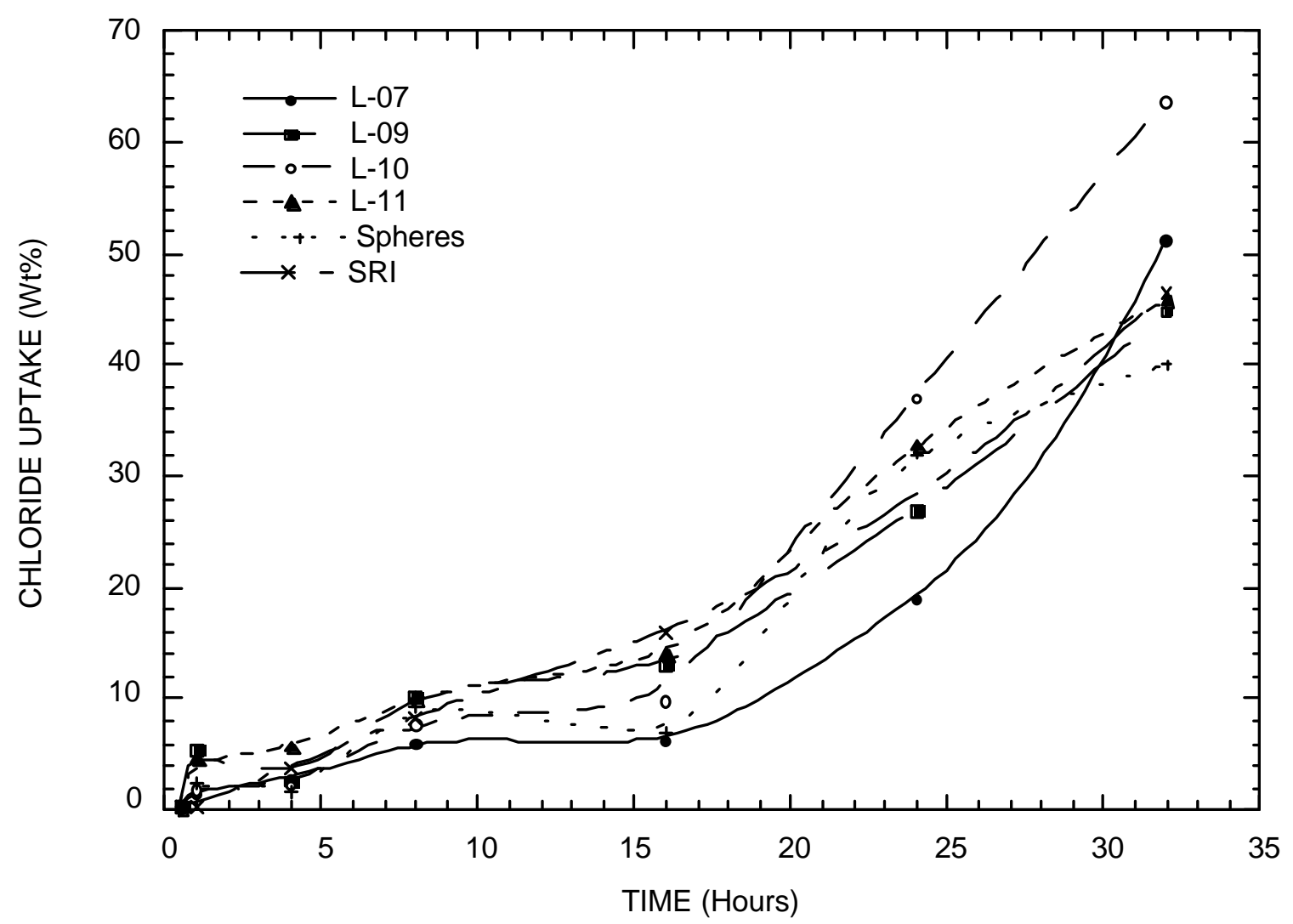

Figure 8. Chloride capacities of various sorbent formulations at $450^{\circ} \mathrm{C}$. 


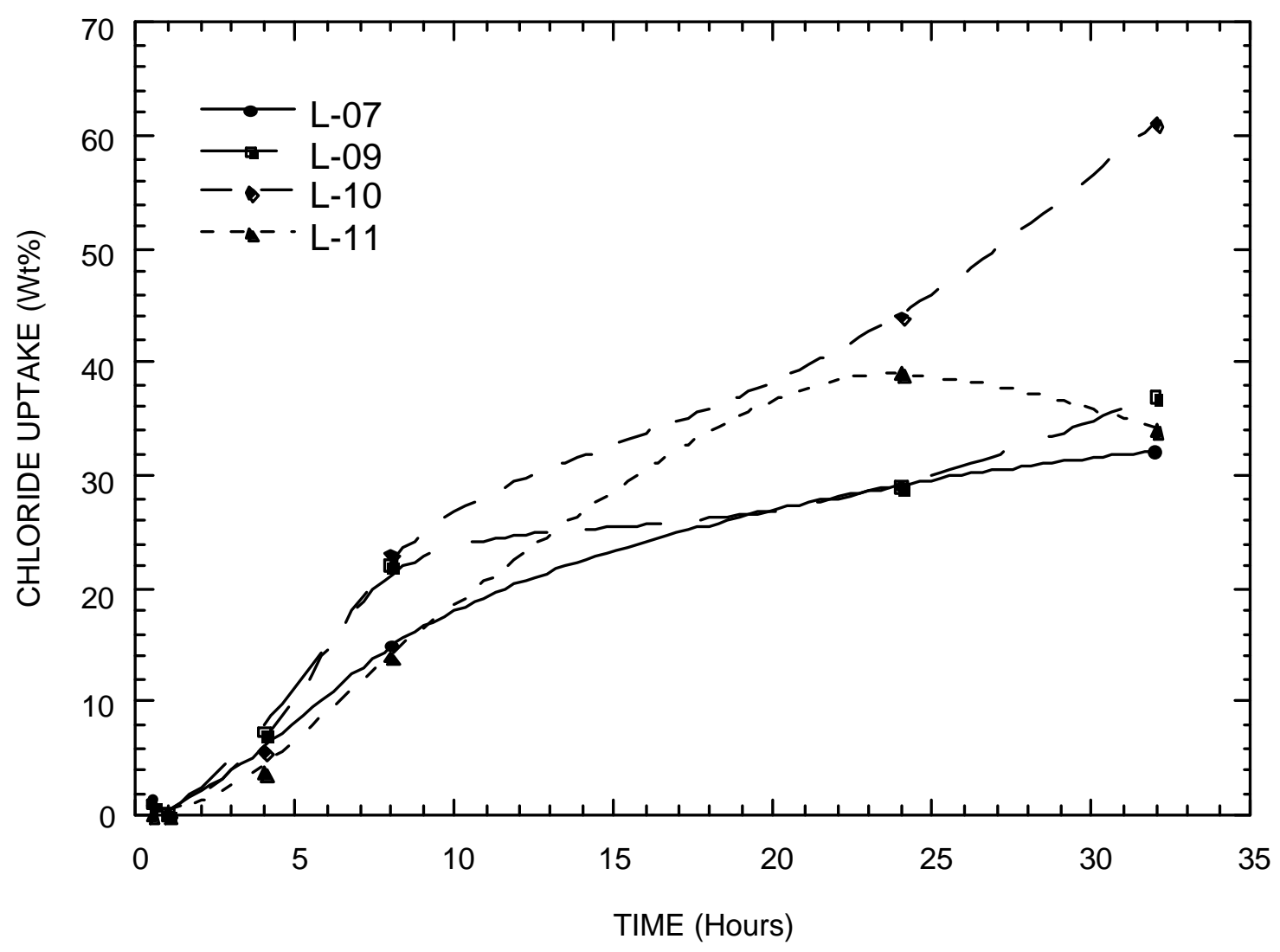

Figure 9. Chloride capacities of various sorbent formulations at $550^{\circ} \mathrm{C}$.

\section{FABRICATION AND CHARACTERIZATION OF FLUIDIZED-BED SORBENTS}

Fluidized-bed reactors are preferred when rapid heat and mass transfer are required.

Because the $\mathrm{HCl}$ concentration in a coal gas is low, reaction of $\mathrm{HCl}$ with the sorbent is unlikely to produce a rapid temperature change in the sorbent pellets. If uncalcined sorbents were to be used to save calcination costs, the endothermic decomposition of the carbonate mineral can be easily accommodated in a fluidized-bed reactor. Rapid decomposition of sodium carbonate generally increases the surface area of the sorbent. The particle sizes of the sorbent needed for the fluidizedbed reactors must be small (50 to $400 \mu \mathrm{m}$ ) to allow fluidization at reasonable gas velocities. The residence time of the gas in this type of reactor is generally shorter than in a fixed- or moving-bed reactors thereby requiring the fluidized-bed reactor sorbents to have a high reaction rate. The sorbent particles must be attrition resistant because particles collide between themselves and with reactor walls during operation. Because the dechlorination sorbents will be discarded after single use, their attrition resistance could be lower than that needed for fluidized-bed hot gas desulfurization sorbents which are regenerated and recycled many times. 


\section{Sorbent Compositions Investigated}

Initially, RTI investigated nahcolite, trona, and a commercial chloride guard compositions to determine the most suitable sorbent for $\mathrm{HCl}$ removal in a fluidized bed reactor. Trona, in the asreceived condition, contained some moisture and it was dried at $120^{\circ} \mathrm{C}$ for $2 \mathrm{~h}$ and then calcined at $482^{\circ} \mathrm{C}$ for $2 \mathrm{~h}$. The calcined trona sorbent was lightly ground and sieved to obtain a sample between 100 and $350 \mu \mathrm{m}$ range. This sorbent was tested in a bubbling-bed reactor. The commerically available United Catalyst Inc.'s (UCI) C125 chloride guard pellets were tested in a fixed-bed reactor. These proprietary $0.2 \mathrm{~cm}$ extruded pellets mainly consisted of $20 \% \mathrm{CaO}, 50 \%$ $\mathrm{ZnO}$, and rest binders.

These initial tests showed that trona and the C125 chloride guard sorbents had some undesirable characteristics. Trona contained iron pyrites which produced $\mathrm{H}_{2} \mathrm{~S}$ during coal gas exposure. Also, a yellow-colored deposit was observed in the reactor exit gas lines. The C125 chloride guard had lower chloride capture capacity than nahcolite-pellets. Based on these observations, nahcolite was chosen as the material of choice for fluidized-bed reactor studies at RTI. Based on the undesirable characteristics of the trona mineral and the commercial chloride guard sotbent, nahcolite was chosen as the material of choice for further testing.

\section{Fabrication of Nahcolite Sorbents}

Nahcolite sorbents for fluidized-bed applications were prepared using four different techniques, which are described below.

Raw Mined Nahcolite (N-01): Raw mined nahcolite (N-01), produced directly by solution mining of the ore,was supplied by North American Chemical Company. The N-01 powder obtained was in size range between 45 and $300 \mu \mathrm{m}$. It was not subjected to any processing and used as a baseline material.

Food-Grade Baking Soda (NG-01): The food-grade baking soda (NG-01) is the commercially available baking soda marketed by Church \& Dwight. Similar to the N-01 sorbent, the NG-01 sorbent was tested without any further processing. The baking soda powder was available in two size ranges: Grade \#3 DF powder which was less than $45 \mu \mathrm{m}$ and Grade \#2 powder which was between 45 and $180 \mu \mathrm{m}$. This material was also used by GE-CRD in tests at their pilot-scale facility at Schenectady, NY.

Granulated Nahcolite (N-23) Formulation: The granulated nahcolite (N-23) sorbent was prepared using the granulation technique. In this technique, the fine raw mined nahcolite 
powder $(<10 \mu \mathrm{m})$ was intimately mixed with suitable binders in a granulator for 3 to 5 minutes. The high shear mixing in the granulator imparted uniform mixing. After 3 to 5 minutes of mixing, a spray of water or aqueous solution of methocel/sodium silicate was sprayed. The tumbling and rolling action of the powder and the fine spray of aqueous media resulted in agglomeration of the fine particles, creating intimately mixed granules. The granules were dried at $120^{\circ} \mathrm{C}$ for about 8 hours and sieved to obtain granulated formulation between 90 and $300 \mu \mathrm{m}$.

Spray-Dried Nahcolite Formulation (NS-Series) The spray-dried sorbent was prepared by Contract Materials Processing, Inc., (CMP) in Baltimore, MD. In the past, CMP has successfully prepared highly reactive and attrition-resistant zinc titanate sorbents for RTI/DOE by spray drying. In this preparation, CMP used the fine grade nahcolite powder supplied by NaTec, Inc. $(<30 \mu \mathrm{m})$. This powder was dissolved in water. Following the dissolution, a slurry was prepared containing $85 \%$ sodium bicarbonate, $10 \%$ kaolinite, and $5 \%$ bentonite. The addition of bentonite and kaolinite clays was necessary to impart attrition resistance to the sorbent particles. The slurry contained about $25 \%$ solids. This slurry was then pumped to a conventional spray dryer equipped with a rotating wheel atomizer.

Initially, a batch of $2.5 \mathrm{~kg}$ ( $5 \mathrm{lb}$ ) of spray-dried sorbent (NS-01) was prepared to investigate the feasibility of spray-drying process. Later, a second batch, $55 \mathrm{~kg}$ (120 lb), of the spray-dried sorbent (NS-02) was produced for pilot-plant testing at GE-CRD. The NS-01 sorbent was calcined in a muffle furnace at $550^{\circ} \mathrm{C}$ to convert sodium bicarbonate into sodium carbonate. Analysis of weight decrease data during calcination indicated that some of the sorbent (about 9\%) had already undergone calcination during spray drying. A comparison of the $\mathrm{Na}_{2} \mathrm{CO}_{3}$ content and the estimated chloride capture capacity of the spray-dried sorbent (NS-01) with the calcined raw mined powder $(\mathrm{N}-01)$ is reported in Table 10.

\section{Table 10}

\section{A COMPARISON OF THE $\mathrm{Na}_{2} \mathrm{CO}_{3}$ CONTENT AND THE ESTIMATED CHLORIDE CAPACITY OF FLUIDIZED-BED SORBENTS.}

\begin{tabular}{lcc} 
Sorbent & $\begin{array}{r}\mathbf{N a}_{\mathbf{2}} \mathbf{C O}_{\mathbf{3}} \text { Content } \\
(\mathbf{w t .} \%)\end{array}$ & $\begin{array}{c}\text { Theoretical Chloride Capacity } \\
(\mathbf{g ~ C l} / \mathbf{1 0 0} \text { g Sorbent) }\end{array}$ \\
\hline N-01 & 100.0 & 67.0 \\
NG-01 & 100.0 & 67.0 \\
N-23 & 86.3 & 57.8 \\
NS-01, 02 & 78.2 & 52.6 \\
\hline
\end{tabular}


As can be seen from Table 10, the $\mathrm{Na}_{2} \mathrm{CO}_{3}$ content of NS-01 and N-23 sorbent was lower than N-01 (or NG-01), because of the presence of clay. As a result, the chloride capture capacities of the NS-01, and NS-02 were about 22\% lower than that of the N-01 formulation.

\section{Physical Properties of Fluidized-Bed Sorbents}

Attrition Resistance: In addition to the chloride capacity and reactivity, the other most important requirement for the sorbent is its high attrition resistance which is an indication of its ability to withstand stresses induced by chemical transformations, fluidization, and pneumatic transport. To this end, the attrition resistance of N-01 and NS-01 sorbents was measured using standard 3-hole air-jet attrition tester (Gupta and Gangwal, 1992). The particle sizes used in the attrition test were in the range from of 75 to $180 \mu \mathrm{m}$. This particle size cut was specifically selected for the attrition test to compare the data for the nahcolite sorbents with the previously obtained data for the FCC catalyst and zinc titanate in this particle size range.

Table 11 lists the attrition test data for N-01, NS-01, FCC catalyst, and a spray-dried zinc titanate sorbent (CMP-5) in 75 to $180 \mu \mathrm{m}$ particle size range. These data are expressed in $5 \mathrm{~h}$ and $20 \mathrm{~h}$ losses. The lower the value of this number, the better is the attrition resistance, as this number indicates the extent of fines generated during the attrition test. As expected, the raw powder (N-01) had a very poor attrition resistance. The attrition resistance of the NS-01 formulation is the highest among the four values reported in Table 11. Furthermore, very little additional fine particles were generated during the $20 \mathrm{~h}$ period, indicating that, in a commercial system, this sorbent should be able to maintain physical integrity over an extended period of time.

\section{Table 11}

\section{ATTRITION RESISTANCE OF FLUIDIZED-BED SORBENTS ${ }^{1}$}

\begin{tabular}{lcc}
\multicolumn{1}{c}{ Sorbent } & $\begin{array}{c}\mathbf{5} \text { h loss } \\
(\mathbf{w t} \%)\end{array}$ & $\begin{array}{c}\mathbf{2 0 ~ h ~ l o s s} \\
(\mathbf{W t} . \%)\end{array}$ \\
\hline N-01 & 12.8 & 37.6 \\
NS-01 & 5.4 & 5.8 \\
CMP-5 ZT & 13.4 & 14.2 \\
FCC Catalyst & 16.0 & 20.0 \\
\hline${ }^{1}$ Calcined at $550^{\circ} \mathrm{C}$ for $1 \mathrm{~h}$. &
\end{tabular}


Surface Area and Pore Volume: Other physical properties of the fluidized-bed sorbents in the fresh, calcined, and after reaction with $\mathrm{HCl}$ vapor were also determined. Surface area was measured using BET technique. The bulk density was determined using the ASTM Test D-4164 method. The pore volume was measured using mercury porosimetry. The results of these measurements are shown in Tables 12 and 13.

Table 12

PHYSICAL PROPERTIES OF THE FRESH, CALCINED, AND SPENT GRANULATED (N-23) NAHCOLITE SORBENT

\begin{tabular}{lccc}
\multicolumn{1}{c}{ Properties } & Fresh & Calcined & Spent \\
\hline Surface area, $\mathrm{m}^{2} / \mathrm{g}$ & 7.80 & 0.65 & 1.37 \\
Bulk density, g/cm & 0.77 & 0.84 & 0.77 \\
$\mathrm{Hg}$ pore vol., $\mathrm{cm}^{3} / \mathrm{g}$ & 0.26 & 0.24 & 0.32 \\
Median pore dia., $\mu \mathrm{m}$ & 0.41 & 1.59 & 1.76 \\
Porosity, \% & 36.5 & 36.5 & 39.4 \\
\hline
\end{tabular}

Table 13

PHYSICAL PROPERTIES OF THE FRESH, CALCINED, AND SPENT NON-GRANULATED (N-01) NAHCOLITE SORBENT

\begin{tabular}{lccc}
\multicolumn{1}{c}{ Properties } & Fresh & Calcined & Spent \\
\hline Surface area, $\mathrm{m}^{2} / \mathrm{g}$ & 8.7 & Note 1 & Note 1 \\
Bulk density, g/cm & 1.12 & 1.13 & 1.15 \\
$\mathrm{Hg}$ pore vol., $\mathrm{cm}^{3} / \mathrm{g}$ & 0.03 & 0.04 & 0.06 \\
Median pore dia., $\mu \mathrm{m}$ & 2.91 & 1.96 & 1.85 \\
Porosity, \% & 7.2 & 8.2 & 11.5 \\
\hline
\end{tabular}

1 The surface area for the calcined and spent N-01 sorbent was too low to be measured. 
The porosity of the fresh $\mathrm{N}-23$ sorbent (which was prepared using the granulation technique as described previously) was about five times that of N-01 sorbent, as was expected. On calcination, the surface area of the N-23 sorbent decreased, whereas the porosity remained nearly the same. A comparison of physical properties of $\mathrm{N}-01$ and $\mathrm{N}-23$ revealed that the calcined $\mathrm{N}-23$ sorbent had a higher surface area and porosity than the N-01 sorbent. The surface area of the calcined and spent N-01 sorbents was too low to be measured by the BET instrument. The reaction of the sorbent with $\mathrm{HCl}$ resulted in an increase in sorbent porosity and surface area. The porosity of the spent $\mathrm{N}-01$ sorbent was $40 \%$ higher than that of the calcined sorbent, whereas the increase in porosity was only $11 \%$ with the $\mathrm{N}-23$ sorbent. The surface area of the spent $\mathrm{N}-23$ sorbent was two times that of the calcined sorbent.

Table 14 compares the physical properties of the NS-01 sorbent before and after the reaction at $550^{\circ} \mathrm{C}$. The sorbent particle size remained unchanged, within the experimental error, after the reaction. However, a significant decline in the reacted sorbent surface area and attrition resistance was observed after the reaction.

\section{Sorbent Reactivity Studies}

Influence of Temperature: A thermogravimetric analyzer (TGA) was used to determine the reactivity of the $\mathrm{NS}-01$ sorbent with $\mathrm{HCl}$ at various temperatures in the range from $350^{\circ}$ to $550^{\circ} \mathrm{C}$. The TGA tests were performed using samples of uncalcined and calcined NS-01 sorbent.

Figure 10 shows the weight loss as a function of time for the calcination of the NS-01 sorbent at three temperatures $\left(350^{\circ}, 450^{\circ}\right.$, and $\left.550^{\circ} \mathrm{C}\right)$. These weight loss curves have two distinct regions. In the first region, the sorbent undergoes rapid decomposition of $\mathrm{NaHCO}_{3}$ to $\mathrm{Na}_{2} \mathrm{CO}_{3}$, resulting in a rapid weight loss. The observed weight loss was only about $20 \%$ because the NS-01 had already undergone partial decomposition during the spray-drying process. In the second region, the weight loss was rather slow and was a function of temperature. The slow weight loss was due to mainly the oxidation of the organic binder used during spray-drying and to a small extent the conversion of any residual $\mathrm{NaHCO}_{3}$ to $\mathrm{Na}_{2} \mathrm{CO}_{3}$.

Table 15 shows the effect of calcination temperature on the surface area of NS-01 sorbent. As expected, an increase in the calcination temperature resulted in a decrease in surface area. When the sorbent was calcined at $550^{\circ} \mathrm{C}$, the surface area decreased from about 5.6 to about $1.8 \mathrm{~m}^{2} / \mathrm{g}$. 
Table 14

\section{COMPARISON OF PHYSICAL AND CHEMICAL PROPERTIES OF FRESH AND REACTED NS-01 SORBENTS}

\begin{tabular}{cccc}
\multicolumn{2}{c}{ Properties } & Fresh NS-01 & Reacted NS-01 \\
\hline $\begin{array}{c}\text { Particle size distribution } \\
\text { Mesh size }\end{array}$ & $\underline{\mu m}$ & $\underline{\text { wt } \%}$ & $\underline{\text { wt } \%}$ \\
+170 & +90 & 0.0 & 9.5 \\
$-170+200$ & $-90+75$ & 13.9 & 16.0 \\
$-200+230$ & $-75+63$ & 38.0 & 35.0 \\
$-230+270$ & $-63+53$ & 20.0 & 20.5 \\
$-270+325$ & $-53+45$ & 20.0 & 17.0 \\
-325 & -45 & $\underline{8.1}$ & $\underline{2.0}$ \\
Total & 100 & 100 \\
Average particle size $(\mu \mathrm{m})$ & 51.0 & 54.5 \\
Surface area $\left(\mathrm{m}^{2} / \mathrm{g}\right)$ & 1.8 & 1.2 \\
Bulk density $\left(\mathrm{g} / \mathrm{cm}^{3}\right)$ & 0.5 & 0.5 \\
Attrition resistance & & 5.4 & 38.9 \\
5 h wt. loss $(\%)$ & 5.8 & 48.0 \\
20 h wt. loss $(\%)$ & & & \\
\hline
\end{tabular}

${ }^{1}$ Measured in a three-hole air-jet attrition tester. 


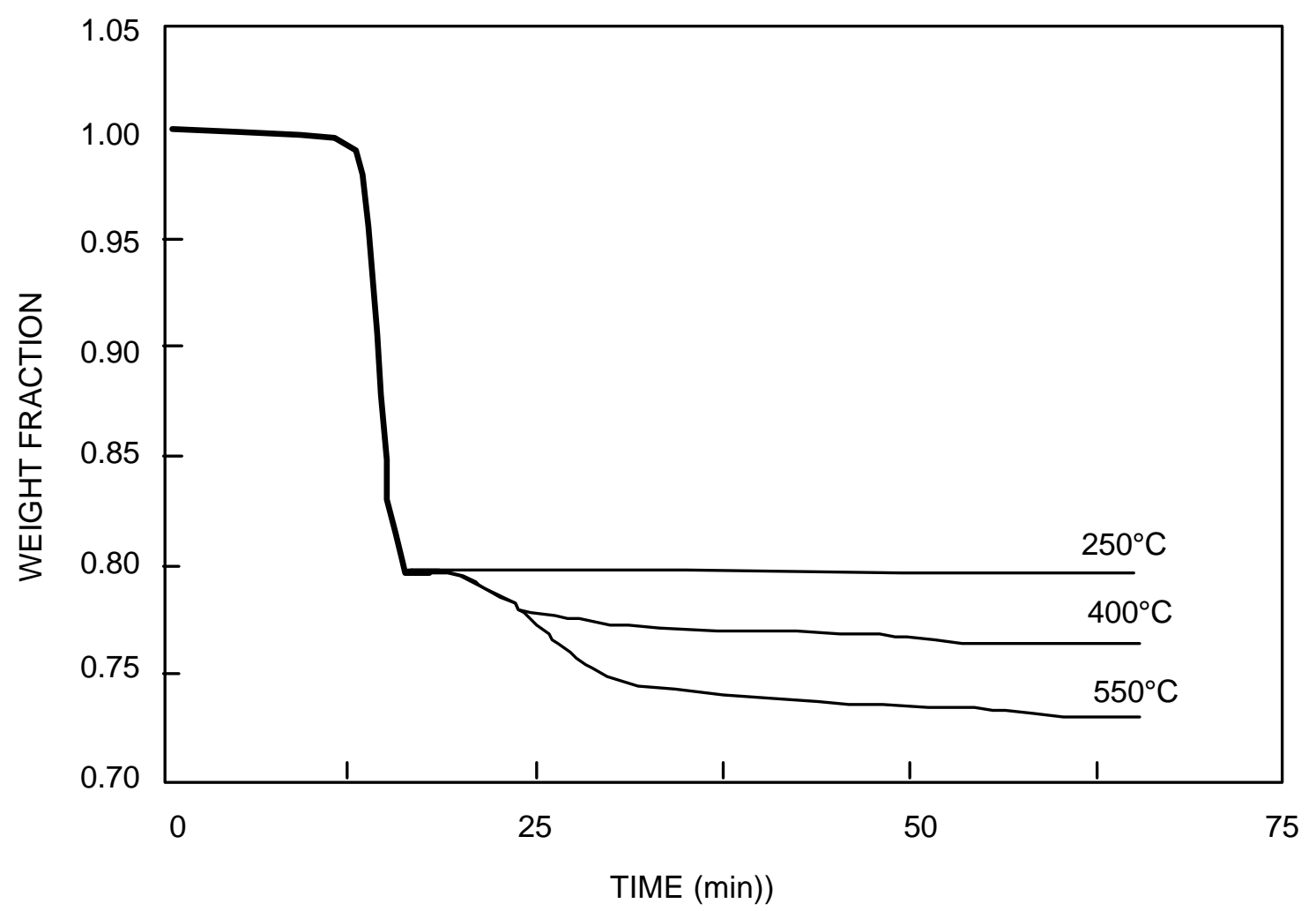

Figure 10. Weight loss during calcination of NS-01 sorbent at various temperatures.

Table 15

INFLUENCE OF CALCINATION TEMPERATURE ON SURFACE AREA OF THE NS-01 SORBENT

\begin{tabular}{cc} 
Temperature $\left({ }^{\circ} \mathbf{C}\right)$ & Surface area $\left(\mathbf{m}^{2} / \mathbf{g}\right)$ \\
\hline \multirow{2}{*}{300} & 5.56 \\
450 & 3.51 \\
550 & 1.80 \\
\hline
\end{tabular}


Screening experiments were conducted to determine the reactivity NS-01 sorbent toward $\mathrm{HCl}$ vapor at temperatures $350^{\circ}$ to $550^{\circ} \mathrm{C}$. The sorbent placed inside TGA apparatus was heated under helium atmosphere to $550^{\circ} \mathrm{C}$ for in-situ calcination. When the calcination was complete, the sample was exposed to a $\mathrm{N}_{2}$-He gas mixture containing $1600 \mathrm{ppmv}$ of $\mathrm{HCl}$ vapor. These $\mathrm{HCl}$ exposure tests were conducted at $350^{\circ}, 450^{\circ}$, and $550^{\circ} \mathrm{C}$.

Figure 10 shows the weight gain profiles at $350^{\circ}, 450^{\circ}$, and $550^{\circ} \mathrm{C}$ for the NS-01 sorbent. The initial weight loss during the calcination period is not shown in the illustration. The weight gain data indicate that the reaction with $\mathrm{HCl}$ vapor was increasingly rapid as the temperature was increased. The weight gain data shown in Figures 10 should be used only to compare the effect of temperature on the reactivity of the sorbent as the maximum weight gain observed exceeded the maximum weight gain calculated for complete chloride absorption by the sorbent. It is believed that an error was made in the measured weight change during calcination.

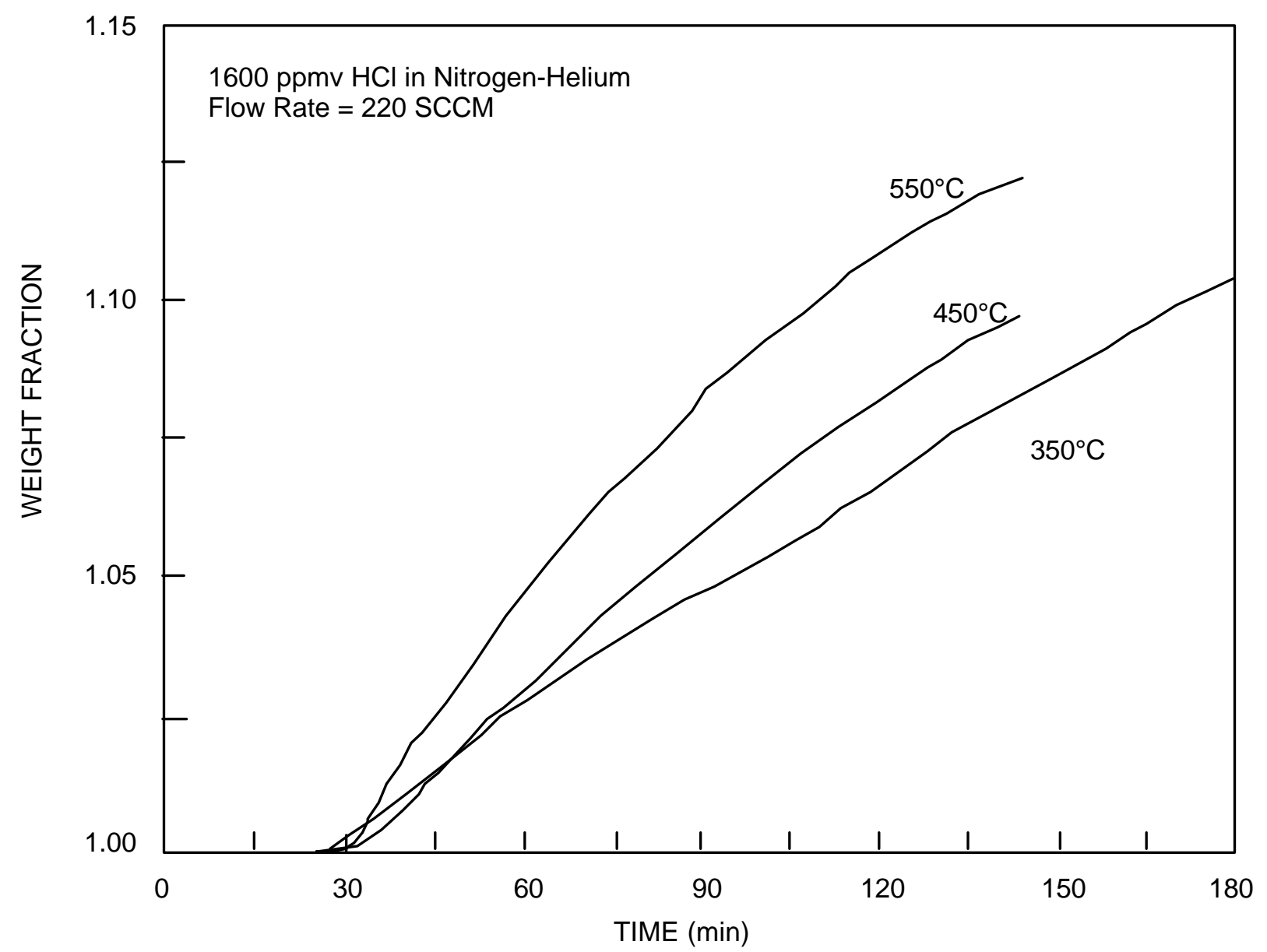

Figure 11 . The $\mathrm{HCl}$ reactivity of NS-01 sorbent, calcined in-situ, at $350^{\circ}$ to $550^{\circ} \mathrm{C}$. 
Figure 12 illustrates the weight gain curves observed when precalcined NS-01 sorbent was exposed to $\mathrm{HCl}$ vapor at various temperatures from $350^{\circ}$ to $550^{\circ} \mathrm{C}$. The sorbent was precalcined at $550^{\circ} \mathrm{C}$ for $1 \mathrm{~h}$. The observed weight gain was similar to that with the uncalcined sorbent except the initial rate of reaction at $350^{\circ} \mathrm{C}$ appears to be rapid. This result could be due to the fact that the calcination could have been more complete when the sorbent was precalcined at $550^{\circ} \mathrm{C}$ than when it was calcined in-situ at $350^{\circ} \mathrm{C}$. These TGA results indicate that chloride capture capacity of the sorbent would increase with an increase in temperature, irrespective of whether it was precalcined or calcined in-situ.

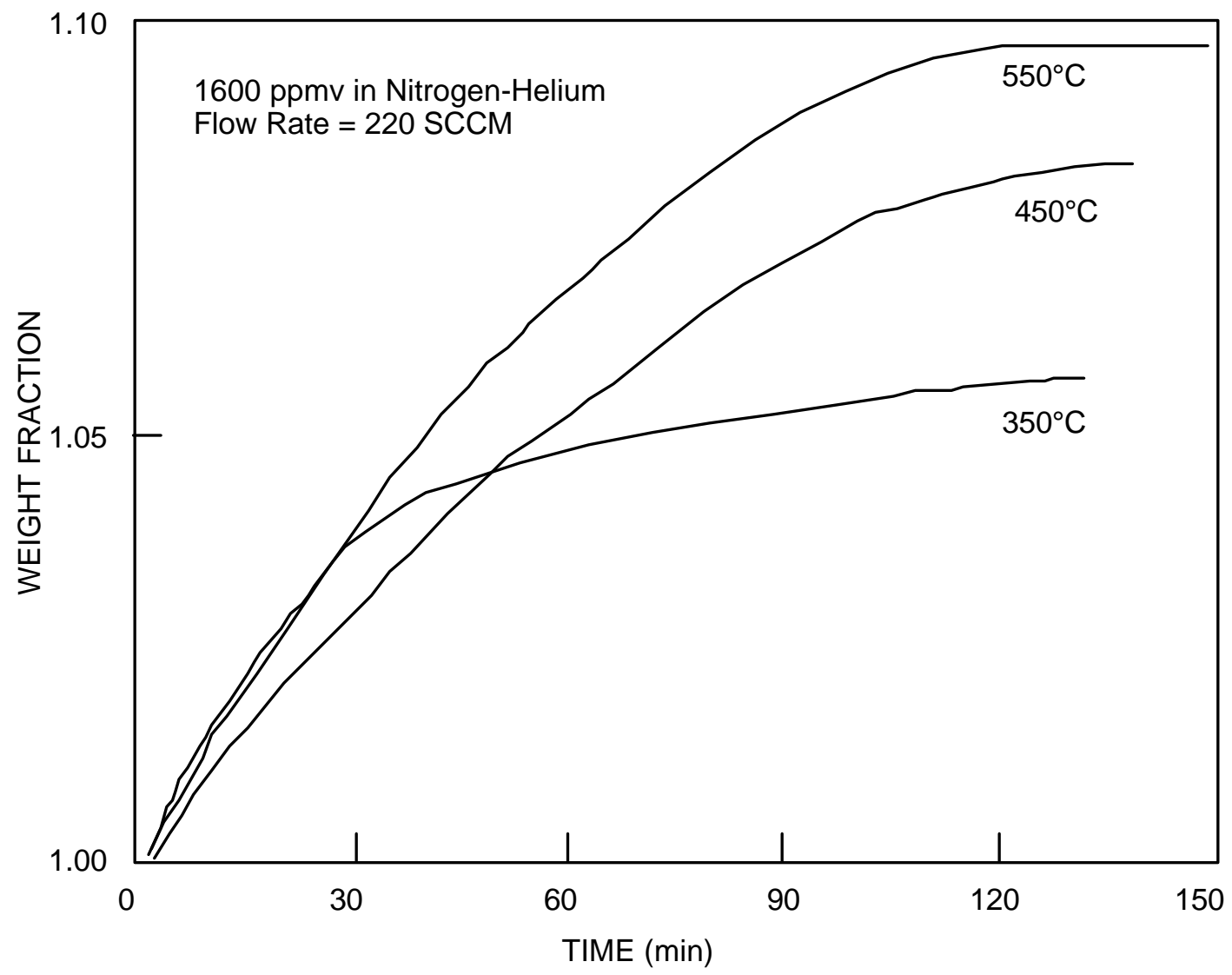

Figure 12 . The $\mathrm{HCl}$ reactivity of precalcined NS-01 sorbent at temperatures from $350^{\circ}$ to $550^{\circ} \mathrm{C}$. 
Influence of Sorbent Preparation Method on HCl Reactivity: The TGA system was also used to study the reactivity of nahcolite sorbents for $\mathrm{HCl}$ vapor at $550^{\circ} \mathrm{C}$. The gas composition used was 1600 ppmv $\mathrm{HCl}$ in $\mathrm{N}_{2}$-He mixture. The sorbents tested were the spray-dried (NS-01), raw mined (N-01), and food-grade baking soda (NG-01). The granulated (N-23) formulation could not be tested due to corrosion problems in the TGA caused by use of $\mathrm{HCl}$ vapor.

Figure 13 shows the TGA reactivity profiles for the above nahcolite formulations. Before starting the $\mathrm{HCl}$ flow, the sorbent was calcined in-situ in the TGA to decompose $\mathrm{NaHCO}_{3}$ to $\mathrm{Na}_{2} \mathrm{CO}_{3}$. TGA weight loss data during calcination indicated nearly complete decomposition of bicarbonate to carbonate for all three samples at $550^{\circ} \mathrm{C}$ in $\mathrm{N}_{2}$. As can be seen from the reactivity profiles, the NG-01 formulation has a very low reactivity compared to the other two materials (NS-01 and N-01). Both the rate of $\mathrm{HCl}$ pickup (indicated by the slope of the curve) and the chloride capture capacity (indicated by final weight gain; about $2 \%$ in this case) for NG-01 is significantly lower than for the other two materials. The spray-dried formulation (NS-01) had the highest rate of $\mathrm{HCl}$ capture and chloride capacity among the three nahcolite sorbents studied.

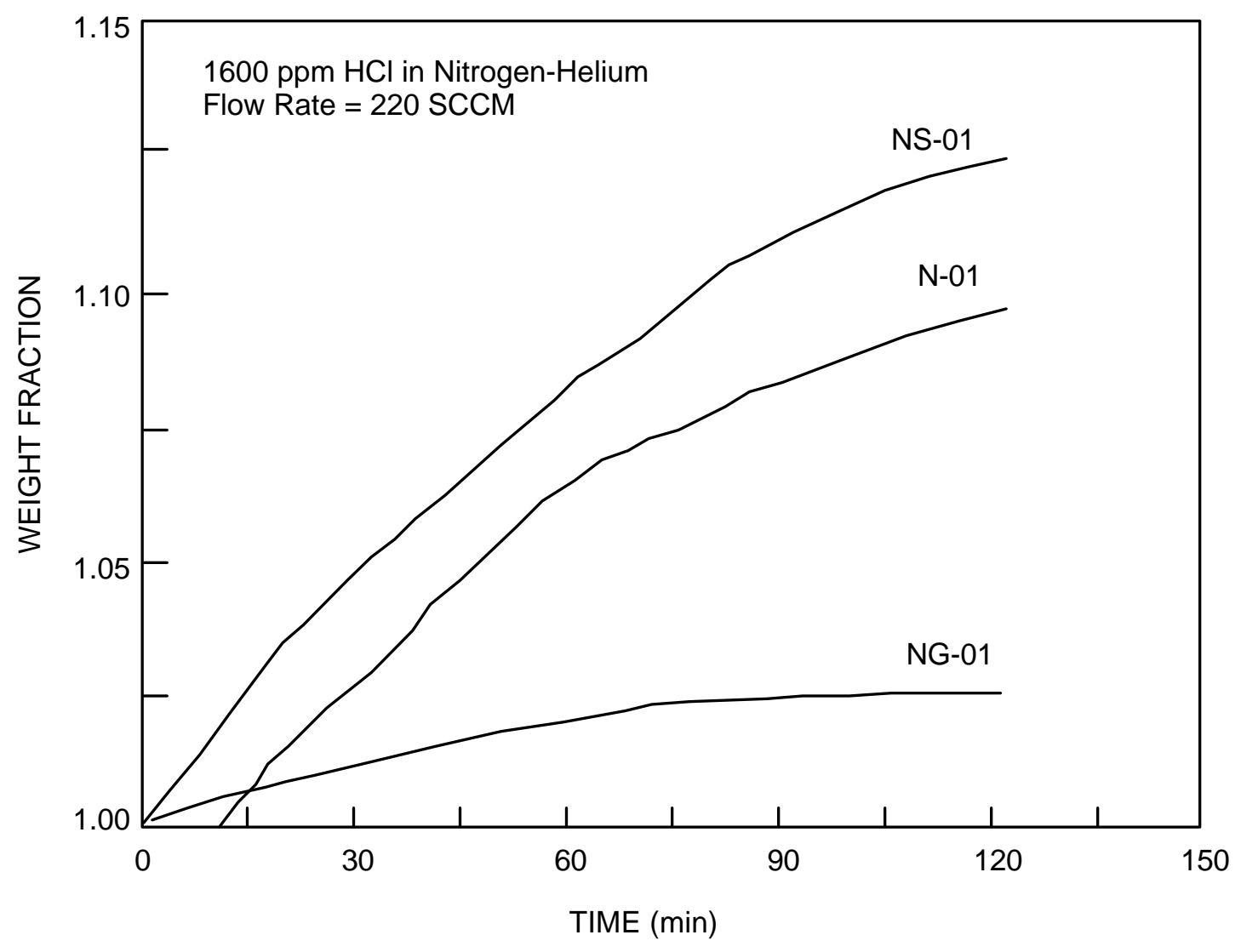

Figure 13. The $\mathrm{HCl}$ reactivity of $\mathrm{N}-01, \mathrm{NG}-01$, and $\mathrm{NS}-01$ at $550^{\circ} \mathrm{C}$. 
Differential Reactor Experiments: RTI conducted a limited number of experiments using differential reactor to determine intrinsic kinetics of the reaction between nahcolite and $\mathrm{HCl}$. The spray-dried (NS-01) sorbent in particle size range 90 and $180 \mu \mathrm{m}$ was used in these studies. In these experiments, an infinitely thin bed was exposed to an $\mathrm{HCl}$-containing gas at a very high space velocity. The reactor used in these experiments was a $1.27-\mathrm{cm}(0.5 \mathrm{in})$ ID quartz tube consisting of two sections divided by a coarse quartz frit. The sorbent was supported on top of the frit. Quartz wool packing was used above the sorbent bed to prevent it from blowing out of the reactor. Coal gas of desired composition was fed at the bottom and the exit gas vented directly to a fume hood. Here, the exit gas was not analyzed, but the chloride content of the spent sorbent was measured after exposure to $\mathrm{HCl}$ by dissolving the sorbent in water and measuring the dissolved chloride ion concentration by an ion chromatograph.

In these experiments about $104 \mathrm{mg}$ of spray-dried nahcolite (NS-01) sorbent (which corresponds to about $0.75 \mathrm{mg}$ calcined sorbent) was used. This bed height and volume were about $2 \mathrm{~mm}$ and $0.25 \mathrm{~cm}^{3}$, respectively. The sorbent was exposed at $550^{\circ} \mathrm{C}$ to a simulated Texaco coal gas atmosphere $\left(37 \% \mathrm{CO}, 38.4 \% \mathrm{H}_{2}, 10.9 \% \mathrm{CO}_{2}, 12.4 \% \mathrm{H}_{2} \mathrm{O}, 1.13 \% \mathrm{H}_{2} \mathrm{~S}\right.$, and $2000 \mathrm{ppmv} \mathrm{HCl}$ ) for several predetermined periods ranging from 5 to $45 \mathrm{~min}$. The gas flow rate was 1670 standard cc per min (SCCM), corresponding to a space velocity of 533,440 $\mathrm{hr}^{-1}$. Typical experiments consisted of calcining the sorbent in $\mathrm{N}_{2}$ for one hour, reacting the sorbent with coal gas for a desired time, and cooling the reactor under $\mathrm{N}_{2}$ flow.

Figure 14 shows the conversion versus time profile of the reaction between nahcolite and $\mathrm{HCl}$. The initial rate of $\mathrm{HCl}$ absorption is very close to the mass transfer limit. After a sorbent conversion of about $70 \%$, pore diffusion appears to be the rate limiting factor. The calculated initial rate from the data shown in Figure 13 was $2.1 \times 10^{-5}$ moles of $\mathrm{HCl} / \mathrm{sec} / \mathrm{g}$ of sorbent while the mass transfer rate calculated for the experimental conditions indicated a value of $3.1 \times 10^{-5}$ mole of $\mathrm{HCl} / \mathrm{sec} / \mathrm{g}$ sorbent. The maximum sorbent conversion was observed to be about $76 \%$, which corresponds to about $38 \mathrm{wt} \%$ sorbent chloride capacity. Although these rate values are approximate, they neverthless provide an engineering estimate for reactor design. 


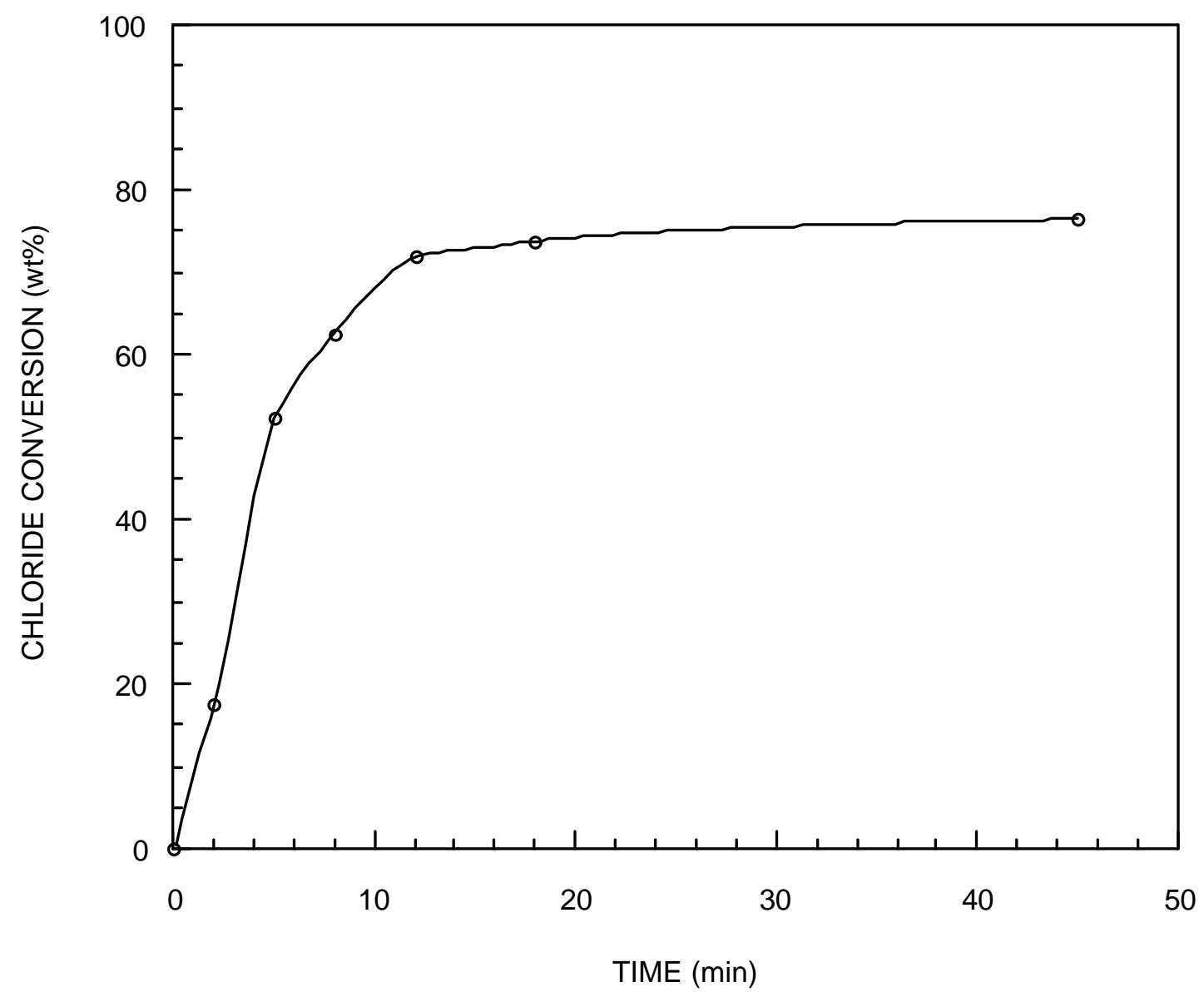

Figure 14. Reactivity of NS-01 sorbent at $550^{\circ} \mathrm{C}$ under differential reaction conditions.

\section{SORBENTS FOR MOVING-BED REACTORS}

GE delivered to SRI two batches of sorbents, one uncalcined (MM1) and one calcined at $650^{\circ} \mathrm{C}$ for $30 \mathrm{~min}(\mathrm{MM} 2)$. The granulated pellets were made using $3 \mathrm{wt} \%$ potassium silicate binder. The attrition loss of MM2 pellets, as determined by the ASTM method, was 4\%, which is quite acceptable for moving-bed application. A batch of the calcined pellets was tested for reactivity toward $\mathrm{HCl}$ vapor in a fixed-bed reactor. The chloride capacity of this sorbent was very low, about $3 \mathrm{wt} \%$ chloride. Because of this low chloride capacity, and the fact that GE-CRD was developing, as part of a different program, a circulating-fluidized-bed reactor for $\mathrm{HCl}$ removal, further investigation of sorbents for moving-bed reactor applications was abandoned. 


\section{BENCH SCALE TEST FACILITIES}

Two fixed-bed, bench-scale reactor systems were installed at SRI. Similarly, two fluidizedbed, bench-scale reactor systems were installed at RTI. Initially, reactors made of quartz were used to test the reactivity of the pellets and powders at $1 \mathrm{~atm}$ pressure. Later, a second a stainless steel pressure vessel was fabricated for tests at elevated pressures. The high-pressure system incorporated a quartz liner to contain sorbent pellets and $\mathrm{HCl}$-containing gas stream. The feed gas blending and the exit gas analysis sections were similar in all systems. The fluidization behavior of the sorbent was visualized using a cold-flow fluidized-bed reactor at RTI. The fluidized-bed reactor at RTI was modified later to simulate a circulating-fluidized-bed reactor. Details of these facilities are described in this section.

\section{ATMOSPHERIC TEST FACILITY FOR SORBENT SCREENING STUDIES}

\section{Fixed-Bed Reactor System}

A 5-cm ID bench-scale fixed-bed reactor was installed at SRI for conducting the reactivity of sorbents for $\mathrm{HCl}$ removal under simulated coal gas composition at $1 \mathrm{~atm}$ pressure (Figure 15). As shown in the schematic diagram, the reactor consisted of a $5 \mathrm{~cm}$ diameter, $100 \mathrm{~cm}$ long quartz tube that was heated by a three-zone electrical furnace. About $200 \mathrm{~g}$ of the sorbent pellets were placed in the center of the furnace. Quartz rings at the top of the sorbent bed allowed preheating of the gas. Additional quartz rings at the bottom of the bed minimized temperature gradients between top and bottom of the bed.

Coal gas mixture containing $\mathrm{CO}, \mathrm{CO}_{2}, \mathrm{H}_{2}$, and $\mathrm{N}_{2}$ was mixed using mass flow controllers and introduced into the reactor from the top. Water was injected at a controlled rate using a metering pump into a glass-frit steam generator. $\mathrm{HCl}$ and $\mathrm{H}_{2} \mathrm{~S}$ were metered through mass flow controllers and mixed with the rest of coal gas components at the top of the preheating zone. A cold trap maintained at $-78.5^{\circ} \mathrm{C}$ (dry-ice temperature) removed the small amount of iron carbonyl impurity normally found in carbon monoxide compressed gas. If the carbonyl impurity was not removed, deposition of iron would occur at about $150^{\circ} \mathrm{C}$. 


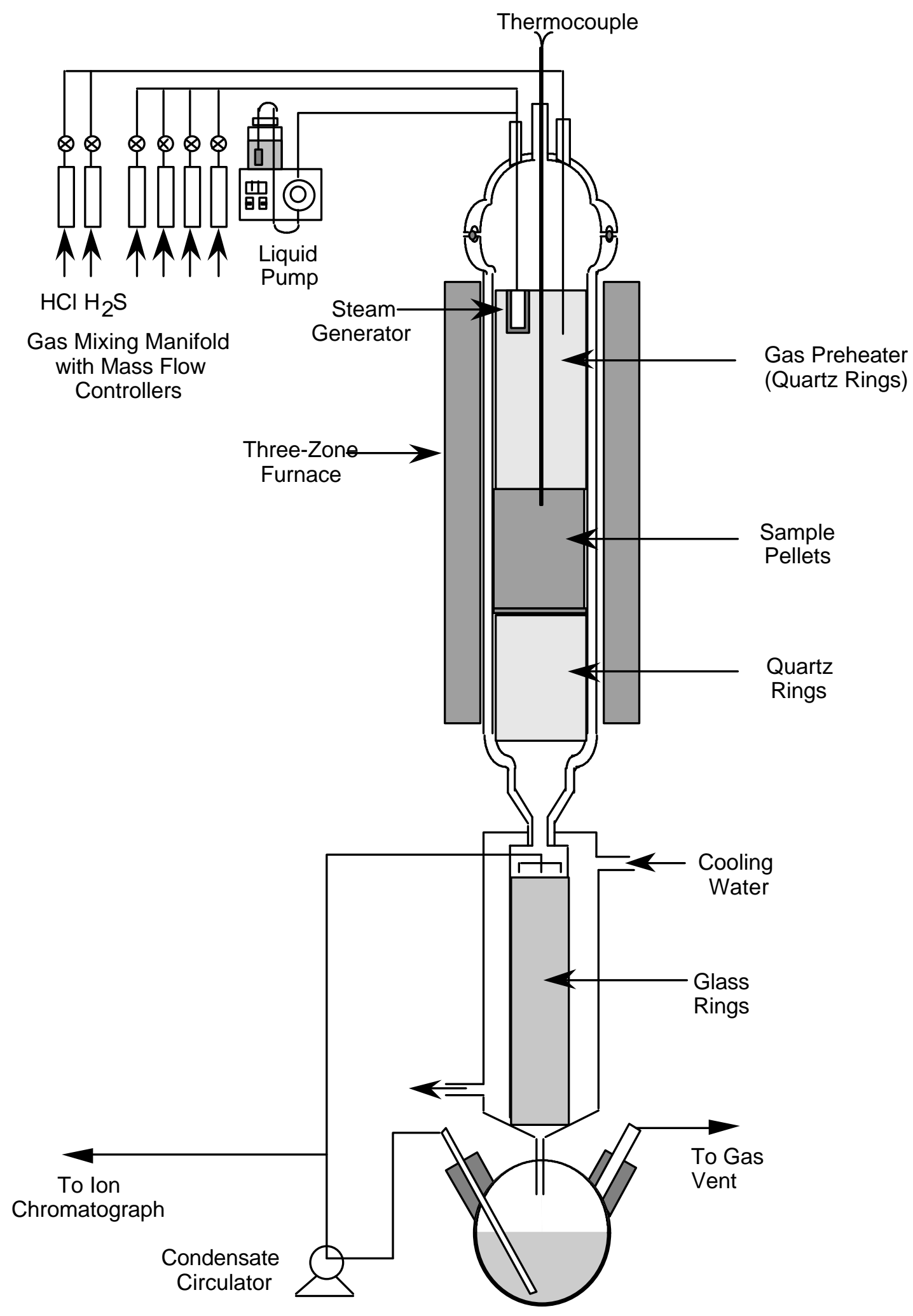

Figure 15. Schematic diagram of the 1 atm fixed-bed reactor. 
The gas stream exiting the reactor was cooled to ambient temperature in a water-cooled jacket filled with glass rings. The steam present in the coal gas mixture was condensed and any $\mathrm{HCl}$ vapor present in the gas stream dissolved in this condensate. The steam condensate was collected in the bottom of the condenser and the remaining gases were vented. The condensate was periodically withdrawn and analyzed for its chloride concentration using an on-line ionchromatograph (IC). The details of chloride analysis using the IC technique is described in a subsequent section.

\section{Fluidized-Bed Reactor System}

A similar system was also installed at RTI for conducting fluidized-bed studies (Figure 16). The quartz reactor column ( $2.6 \mathrm{~cm}-\mathrm{ID}$ and $100 \mathrm{~cm}$ long) consisted of two sections separated by a coarse quartz frit located midway in the column. The section below the frit (lower section of the reactor, which was $50 \mathrm{~cm}$ long $)$ was packed with quartz rings $(\sim 0.5 \mathrm{~cm}$ diameter and $\sim 0.7 \mathrm{~cm}$ long). A high-performance liquid chromatography (HPLC) pump fed distilled water to the reactor via a quartz capillary tube, which extended from the reactor bottom to about $5 \mathrm{~cm}$ below the frit. During flow through the capillary tube, water formed steam, which was then mixed with the coal gas at $5 \mathrm{~cm}$ below the frit. The coal gas containing $\mathrm{HCl}$ was directly fed into the reactor.

In the reactor, the sorbent was supported on the frit. The effluent gas from the sorbent bed passed through a condenser, where steam and $\mathrm{HCl}$ were condensed in the catch pot. The coolant in the condenser was maintained at $5^{\circ} \mathrm{C}$ using a chiller. The non-condensable gases were vented to the exhaust system. The cumulative chloride ion concentration of the aqueous condensate was measured periodically using an ion chromatograph.

\section{HIGH PRESSURE TEST FACILITIES}

\section{Fixed-Bed Reactor System}

A high-pressure fixed-bed reactor system was installed at SRI's high bay building. The

pressure vessel was designed to operate up to a temperature of $650^{\circ} \mathrm{C}$ and a pressure of $300 \mathrm{psig}$. Figure 17 is a schematic diagram of the assembly. 


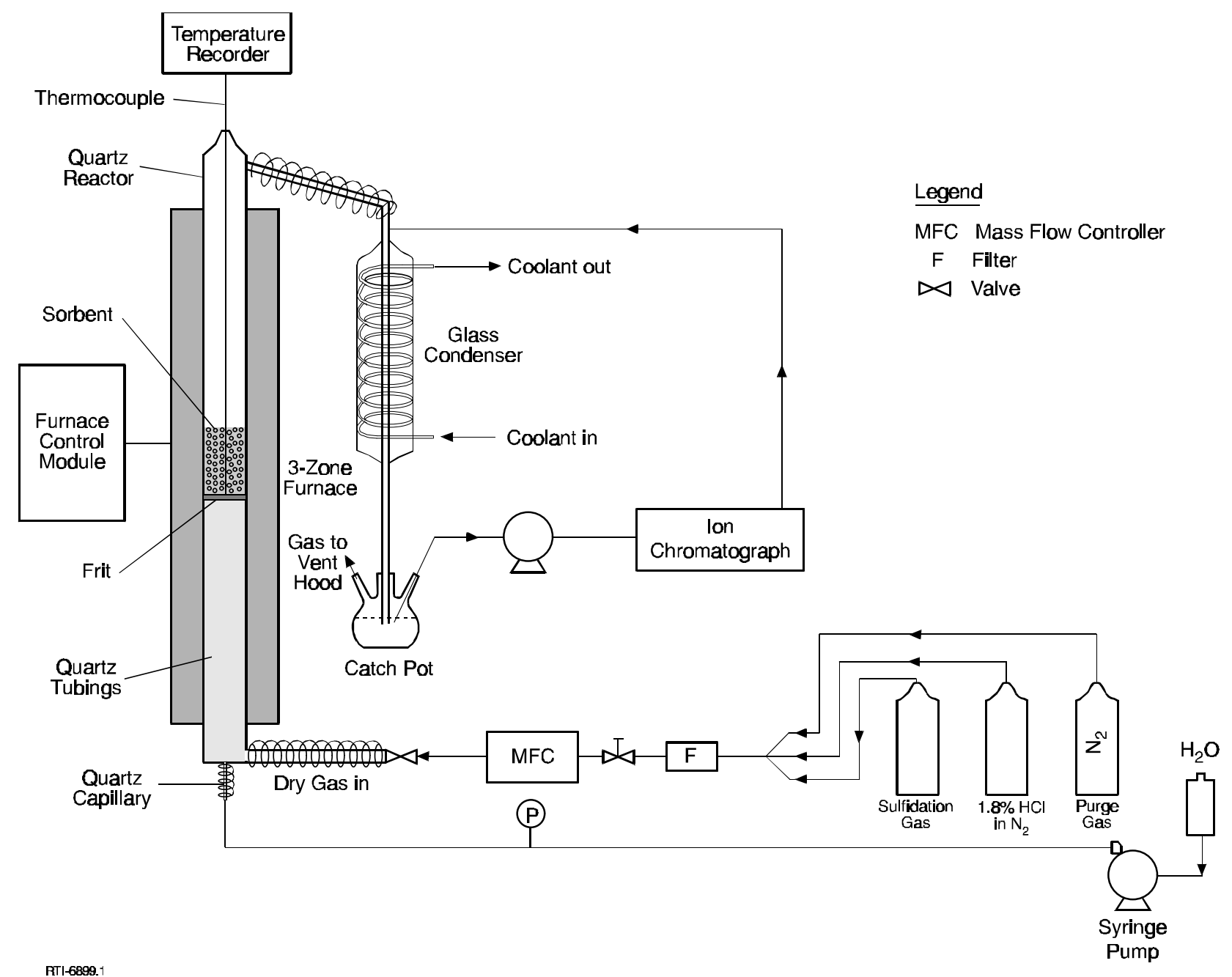

Figure 16. Schematic diagram of the atmospheric fluidized-bed reactor 


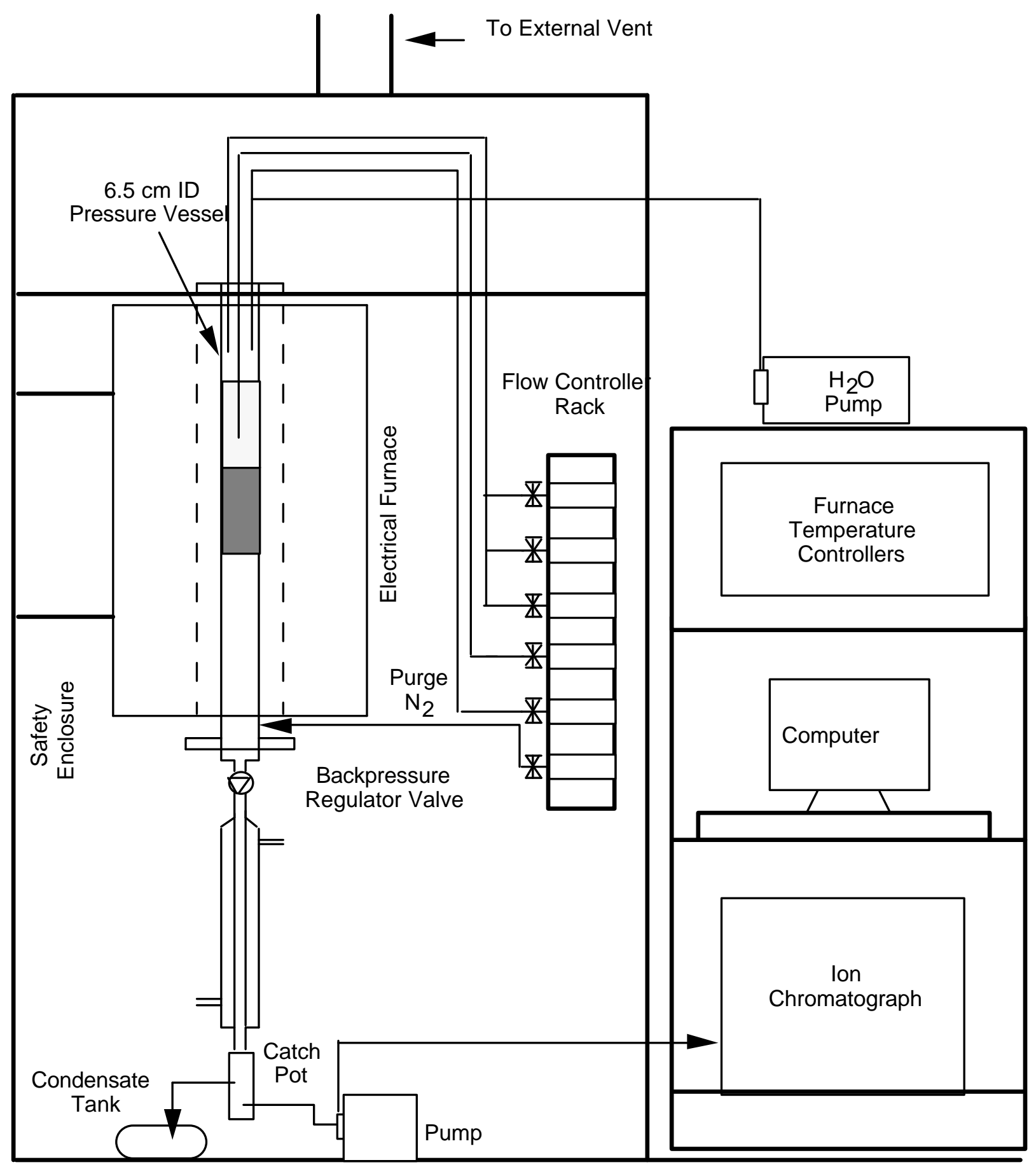

Figure 17. Schematic diagram of the high-pressure fixed-bed reactor system. 
The $5 \mathrm{~cm}$-ID x $91 \mathrm{~cm}$ long stainless steel pressure vessel contained a quartz tube insert in which sorbent pellets were placed. The vessel was heated by an external three-zone electrical furnace. The simulated coal gas was introduced into the vessel by blending individual gases using mass flow controllers. Steam was generated at the top of the reactor by vaporizing liquid water. A small flow of nitrogen gas was passed through the annulus between the quartz tube and the stainless steel reactor to prevent corrosion of the metal.

Downstream of the sorbent bed, the quartz tube was joined to the bottom flange with a Hastelloy (C22) fitting and graphite seals. Hastelloy tubing was also used to connect the outlet of the reactor to the pressure-reducing, servo-controlled valve made of Hastelloy. The gases exiting the valve were cooled using a glass condenser to condense steam and dissolved $\mathrm{HCl}$ vapor. The steam condensate containing the residual $\mathrm{HCl}$ vapor dripped into a glass catch pot. About $50 \mathrm{ml}$ of the condensate was retained in the catch pot and the overflow liquid was drained into a tank. A sample of the condensate was pumped by a peristaltic pump into the IC for chloride analysis. The chloride analysis was performed in about 10 min-intervals. The noncondensable gases were then vented in the atmosphere after passing through a $\mathrm{CaSO}_{4}$ bed (Drierite) to remove any uncondensed water and a $\mathrm{ZnO}$ bed to remove $\mathrm{H}_{2} \mathrm{~S}$.

The cylinders containing toxic gases $\left(\mathrm{CO}, \mathrm{HCl}\right.$, and $\left.\mathrm{H}_{2} \mathrm{~S}\right)$ were stored inside a vented gas cabinet. The pressure vessel and mass flow controllers were housed inside a safety enclosure made of laminated plastic. The safety enclosure was also vented through its top so that the operating personnel would not be exposed to any toxic gases.

\section{Fluidized-Bed Reactor System}

The schematic diagrams of the fluidized-bed reactor system and the reactor are shown in Figures 18 and 19, respectively. The reactor was contained inside a stainless steel shell, which was externally heated by a three-zone electric furnace. The reactor consisted of two parts separated by a flange. The bottom portion was made of quartz $(5 \mathrm{~cm}$-ID) whereas the top portion was made of Hastealloy, which was considerably resistant to corrosion by $\mathrm{HCl}$. The sorbent was supported on a 3-mm thick coarse quartz distributor inside the quartz tube. A 3-mm thick quartz filter located between the quartz and Hastealloy shell prevented fine sorbent particles elutriating into the reactor exit line and plugging of the pressure control valve downstream. The reactor temperature was monitored continuously using a type-K thermocouple, which was located below the quartz distributor. A pressure gauge at the reactor exit indicated the pressure inside the reactor. The system pressure was controlled by a servo-control valve located at the reactor exit. The above reactor system capable of operating both in bubbling fluidized- and fixed-bed mode. 


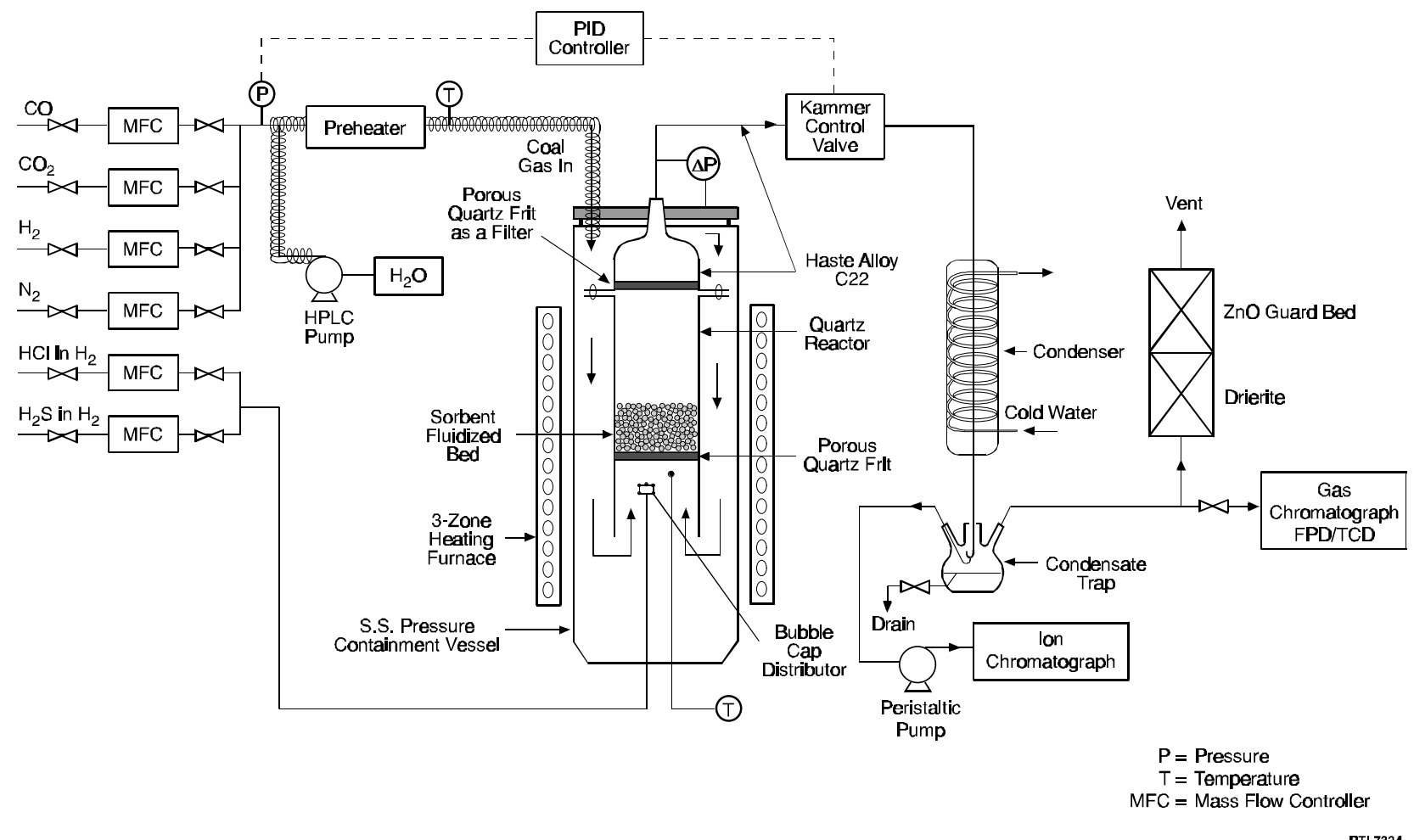

Figure 18: Schematic diagram of the high-pressure, fluidized-bed reactor system 


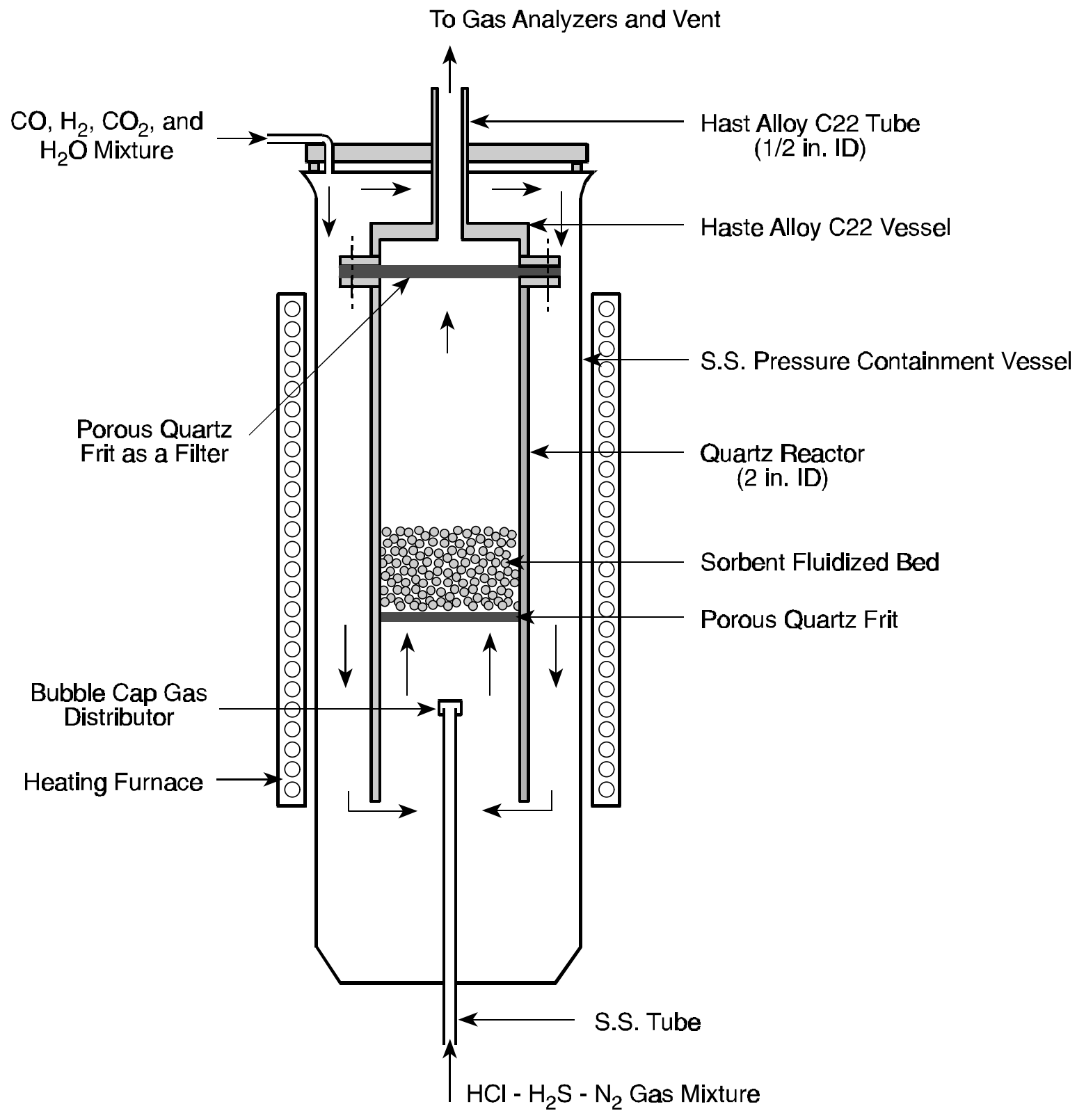

RTI-7884.2

Figure 19: Schematic diagram of the fluidized-bed reactor 
Simulated coal gas was generated by blending metered quantities of pure component gases using electronic mass flow controllers. An HPLC pump fed the desired quantity of deionized water into the system to generate steam. The coal gas and water were heated in a preheater before feeding to the top of the reactor. The coal gas and the steam generated in the preheater were further heated while passing through the annulus between the stainless steel shell and the quartz reactor before entering the sorbent bed. The $\mathrm{HCl} / \mathrm{H}_{2}$ and $\mathrm{H}_{2} \mathrm{~S} / \mathrm{H}_{2}$ mixtures were fed through a bubble cap distributor located about $6 \mathrm{~cm}$ below the quartz distributor and inside the quartz reactor. This arrangement of feeding the corrosive $\mathrm{HCl}$ and $\mathrm{H}_{2} \mathrm{~S}$ gases minimized their contact with the stainless steel, thereby preventing the corrosion of the pressure vessel.

The effluent gases from the reactor were passed through the shell side of a specially designed water-cooled condenser, where steam and $\mathrm{HCl}$ were condensed out. The aqueous acidic condensate continuously dropped into a $3 \mathrm{ml}$ catch pot located inside a 3 liter flask. Condensate in excess of 3 $\mathrm{ml}$ dropped in the flask and was drained periodically. The condensate from the catch-pot was pumped to the IC using a peristaltic pump. Every 30 minutes from the start of the experi-ment, a small quantity of condensate was automatically injected into the sampling loop of the IC and analyzed for its chloride ion concentration. This chloride concentration from the IC yielded the instantaneous $\mathrm{HCl}$ concentration in the reactor outlet gas. The remaining condensate from the IC was sent to the drain. The noncondensable gases were then vented in the atmosphere after passing through a drierite to remove any uncondensed water and a $\mathrm{ZnO}$ guard bed to remove $\mathrm{H}_{2} \mathrm{~S}$.

In all the high-pressure tests, the sorbent was loaded in the reactor and calcined at $1 \mathrm{~atm}$ pressure in $\mathrm{N}_{2}$ for $1 \mathrm{~h}$ at the desired temperature. Following calcination, the reactor was pressurized to the test pressure and coal gas passed until breakthrough occurred. After the breakthrough, the reactor was cooled with $\mathrm{N}_{2}$ purge flow.

\section{Circulating-Fluidized-Bed Reactor System}

The high-temperature, high-pressure fluidized-bed reactor system was modified to conduct bench-scale testing in entrained-bed or circulating-fluidized-bed (CFB) mode. A quartz internal cyclone was installed in the $5 \mathrm{~cm}$ diameter quartz tube portion of the reactor (Figure 20). The bottom most portion of the cyclone was about $2 \mathrm{~cm}$ above the coarse quartz distributor. The use of cyclone in the CFB mode enabled sorbent testing under entrained-bed conditions. In these tests, the gas velocities used (> $20 \mathrm{~cm} / \mathrm{s}$ ) were higher than the terminal velocity of the sorbent particles, thereby entraining the sorbent particles. The entrained particles and gas stream passed through the cyclone where the gas stream and particles were separated. The gas stream flowed out through the reactor exit and the sorbent particles were returned to the reactor via a standpipe. 


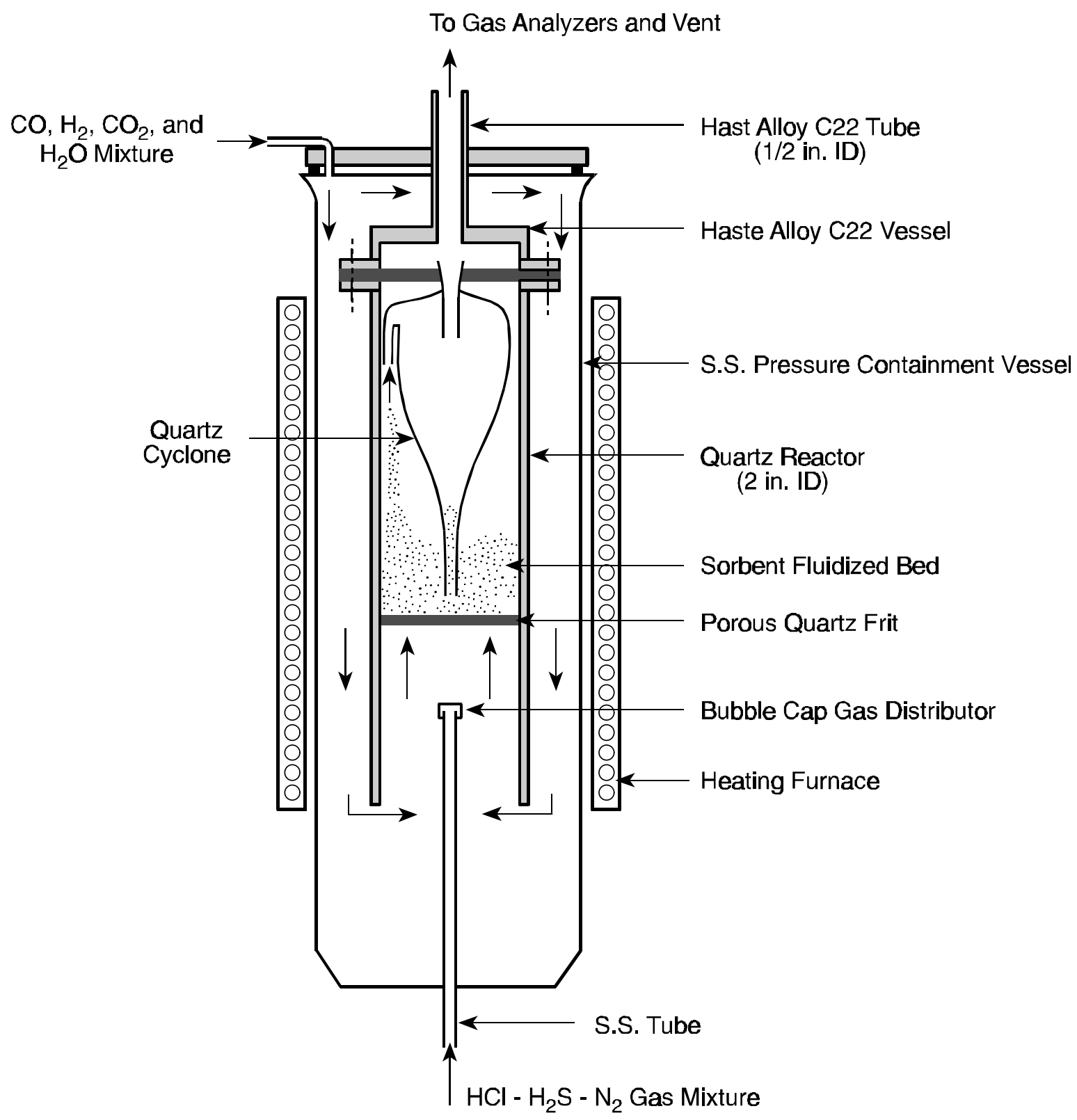

RTI-7884.1

Figure 20: Schematic diagram of the circulating-fluidized-bed reactor 


\section{Cold-Flow Fluidized-Bed Unit}

A cold-flow system was designed and built to determine the fluidization characteristics, primarily the minimum fluidization velocity, of the fluidizable sorbents. This system consisted of a $5 \mathrm{~cm}$-ID quartz cage that was used in the HTHP reactor, a metered gas flow system and a differential pressure gauge. Figure 21 shows the typical fluidization behavior of the calcined NS-01 sorbent. As shown in Figure 21, a sharp transition occurs between the packed- and fluidized-bed regimes at the minimum fluidization velocity. This value of experimentally measured minimum fluidization velocity was used to calculate the operating conditions of the atmopsheric and HTHP system. The cold-flow unit was also used to study sorbent flow characteristics in the CFB mode by inserting a quartz cyclone with a standpipe in the center. Effect of gas velocity on particle entrainment and the flowability characteristics of the sorbent was also studied using this cold-flow unit.

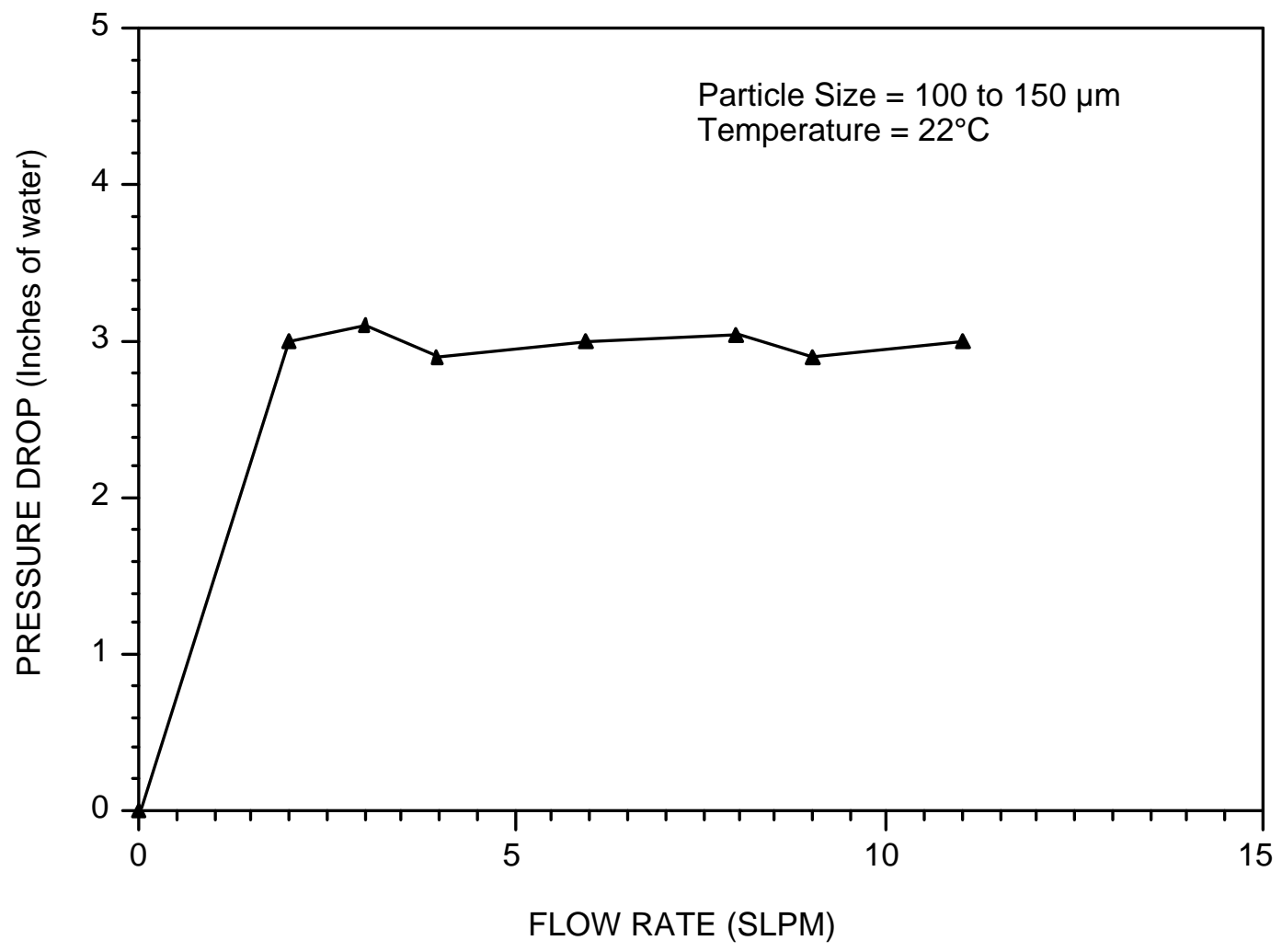

Figure 21. Typical fluidization behavior of NS-01 sorbent. 


\section{Ion Chromatograph for HCl Analysis}

Analysis of the $\mathrm{HCl}$ vapor in the reactor exit gas was performed at SRI and RTI by the same method. In this method, the $\mathrm{HCl}$ vapor was dissolved in the steam condensate and the chloride concentration of the aqueous condensate was determined using a Dionex D100 Ion Chromatrograph (IC) at both SRI and RTI. In the IC technique, the chloride concentration in an aqueous sample is determined by measuring the change in conductivity caused by the presence of chloride ions. The conductivity of a solution is measured by applying an alternating voltage between two electrodes in a conductivity cell. At any instant in time, negatively charged anions migrate toward the positive electrode and positively charged cations migrate toward the negative electrode. The conductivity of the solution is the conductance which would be measured in a standard cell containing electrodes of $1 \mathrm{~cm}^{2}$ surface area held $1 \mathrm{~cm}$ apart. The units of conductivity are siemens per $\mathrm{cm}(\mathrm{S} / \mathrm{cm})$.

The conductivity of a dilute solution is directly proportional to concentration of the ions present in the solution. The conductivity is affected by the choice of solvent, with principal effects being changes in ion solvation and solvent viscosity. Ions are more mobile in solvents of lower viscosity. The increase in the conductivity of an aqueous solution is typically $<2 \%$ per ${ }^{\circ} \mathrm{C}$.

The ionic species detected by conductivity are usually separated by ion-exchange and ionpair chromatography. These separation methods require eluents containing strong electrolytes. However, the presence of strong electrolytes results in the detector being overwhelmed by the ions in the eluent. This problem is solved by neutralizing the eluent by a regenerant in a suppressor. For anion IC, the suppressor membranes are cation exchange polymers, which allow cations to pass freely but exclude anions. In the suppressor, the cations of the eluent (for example, $\mathrm{Na}^{+}$when the eluent is $\mathrm{Na}_{2} \mathrm{CO}_{3} / \mathrm{NaHCO}_{3}$ buffer) are replaced by $\mathrm{H}^{+}$of the regenerant neutralizing the carbonate eluent and providing the highly conductive hydrogen ion to the analyte anion (say $\mathrm{Cl}^{-}$ anion when the analyte is $\mathrm{HCl}$ ). The analyte anion along with the hydrogen counter ion then flows to the conductivity detector cell. The suppressor both lowers the background conductivity (and therefore the baseline noise and drift) and increases the signal-to-noise ratio.

The DX-100 Ion Chromatograph consists of a conductivity detector cell, an anion selfregenerating suppressor with autosuppression recycle mode, a separator column, a guard column, a sample injection system, and the eluent supply system. The eluent is a $\mathrm{Na}_{2} \mathrm{CO}_{3} / \mathrm{NaHCO}_{3}$ buffer solution, and the analyte is the condensed $\mathrm{HCl}$ from the reactor.

The flow-through conductivity detector cell $(1.25 \mu \mathrm{l})$ is a high-density polymeric material containing two passivated 316 S.S. electrodes permanently sealed into the cell. The detector cell 
constant is calibrated electronically. A thermistor located slightly downstream from the electrodes measures the temperature of the liquid inside the cell and is used for temperature compensation.

The anion self-regenerating suppression system (ASRS) provides continuous suppression of traditional eluents. It includes two regenerant compartments and one eluent compartment separated by ion exchange membranes. The eluent and regenerant are separated by the membrane and flow in opposite direction to each other. The regenerant is water. The neutralized eluent from the ASRS after flowing through the conductivity cell is redirected to the regenerant compartment of the ASRS, thus supplying it with a source of water. The electrodes in the regenerant compartment electrolyze the water, supplying regenerant hydronium ions $\left(\mathrm{H}_{3} \mathrm{O}^{+}\right)$, which pass through the membrane and neutralize the eluent The eluent cations are simultaneously passed into the regenerant chamber to maintain charge balance. The amount of water flowing through the regenerant chambers is therefore limited to the eluent flow rate.

The separator column ( 4 x $250 \mathrm{~mm}$ ) is an ion-exchange column composed of a $12 \mu \mathrm{m}$ highly cross-linked polyethylvinylbenzene/divinylbenzene substrate agglomerated with anion exchange latex that has been completely aminated. The guard column is placed prior to the separator column to prevent sample contaminants from eluting onto the analytical column. It is more cost effective to replace a guard column than to replace a separator column.

The eluent is continuously pumped to the system. On injecting the analyte sample and initiating the injection mode on the DX-100, $10 \mu \mathrm{l}$ of the analyte is injected into the sample loop and then to the separator column, where the anions are retained depending on their affinity to the ion-exchange membrane. The analyte anions are carried to the conductivity detector cell via the ASRS. The chloride anions are detected at about $1.5 \mathrm{~min}$ after sample injection. The analyte and eluent not flown through the sample loop are flown as waste through separate lines. The operation of sample injection can be automated by pumping the analyte continuously and initiating the analyte injection at regular intervals. Also, the analyte not injected in the sample loop can be recirculated back to the condensate catch pot for determination of cummulative chloride concentration.

The $\mathrm{HCl}$ vapor concentration in the reactor exit gas was calculated from the steam content of the gas and the total flow of the gas stream. The IC technique was also used to determine the chloride content of the spent sorbent. A known amount of spent sorbent was dissolved in deionized water and then the chloride content of the solution was determined by using the IC. 


\section{BENCH-SCALE TESTING}

The reactivity of the sorbents for $\mathrm{HCl}$ vapor in simulated coal gas streams was determined using the bench-scale fixed-bed reactors at SRI and fluidized-bed reactors at RTI. In some cases, RTI also conducted a limited number of fixed-bed tests at its facilities. The results of the bench scale runs, including paramatric testing, are described in this section.

\section{GAS COMPOSITION}

Simulated coal gas compositions representative of an oxygen-blown entrained-bed, slagging gasifier (Texaco type) and an air-blown, fluidized-bed gasifier (DOE's Gasification Product Improvement Facility-GPIF) were used in the studies. The nominal compositions of these gas mixtures are shown in Table 16.

Table 16

GAS COMPOSITION OF SIMULATED COAL GAS MIXTURES

\begin{tabular}{ccc} 
& \multicolumn{2}{c}{ Gas Composition (Mole\%) } \\
\cline { 2 - 3 } Component & Texaco Type & GPIF Type \\
\hline $\mathrm{CO}$ & 37.0 & 21.6 \\
$\mathrm{H}_{2}$ & 38.4 & 12.5 \\
$\mathrm{CO}_{2}$ & 10.9 & 2.4 \\
$\mathrm{H}_{2} \mathrm{O}$ & 12.4 & 25.0 \\
$\mathrm{~N}_{2}$ & 0.0 & 38.0 \\
$\mathrm{H}_{2} \mathrm{~S}$ & 1.1 & 0.2 \\
$\mathrm{HCl}$ & 0.2 & 0.2 \\
\hline
\end{tabular}




\section{FIXED-BED REACTOR TESTS}

Reactor Performance Verification: The performance of the atmospheric pressure bench scale reactor was verified by testing nahcolite pellets made with $10 \mathrm{wt} \%$ bentonite binder. About $200 \mathrm{~g}$ of $4.5 \mathrm{~cm}$ diameter nahcolite pellets $(\mathrm{N}-08)$ were placed in the bench-scale reactor and were exposed to a simulated Texaco coal gas stream containing $2000 \mathrm{ppmv} \mathrm{HCl}$. A gas flow of about 10 SLM corresponding to a space velocity of $3000 \mathrm{~h}^{-1}$ was passed through the sorbent bed $(12 \mathrm{~cm}$ deep) kept at $550^{\circ} \mathrm{C}$. The experimental results (Figure 22) indicated that the $\mathrm{HCl}$ concentration in the reactor effluent remained at about the $0.3 \mathrm{ppm}$ level for about $17 \mathrm{~h}$. After this period of time, the $\mathrm{HCl}$ concentration increased and the $10 \mathrm{ppm}$ level was reached after about $27 \mathrm{~h}$.

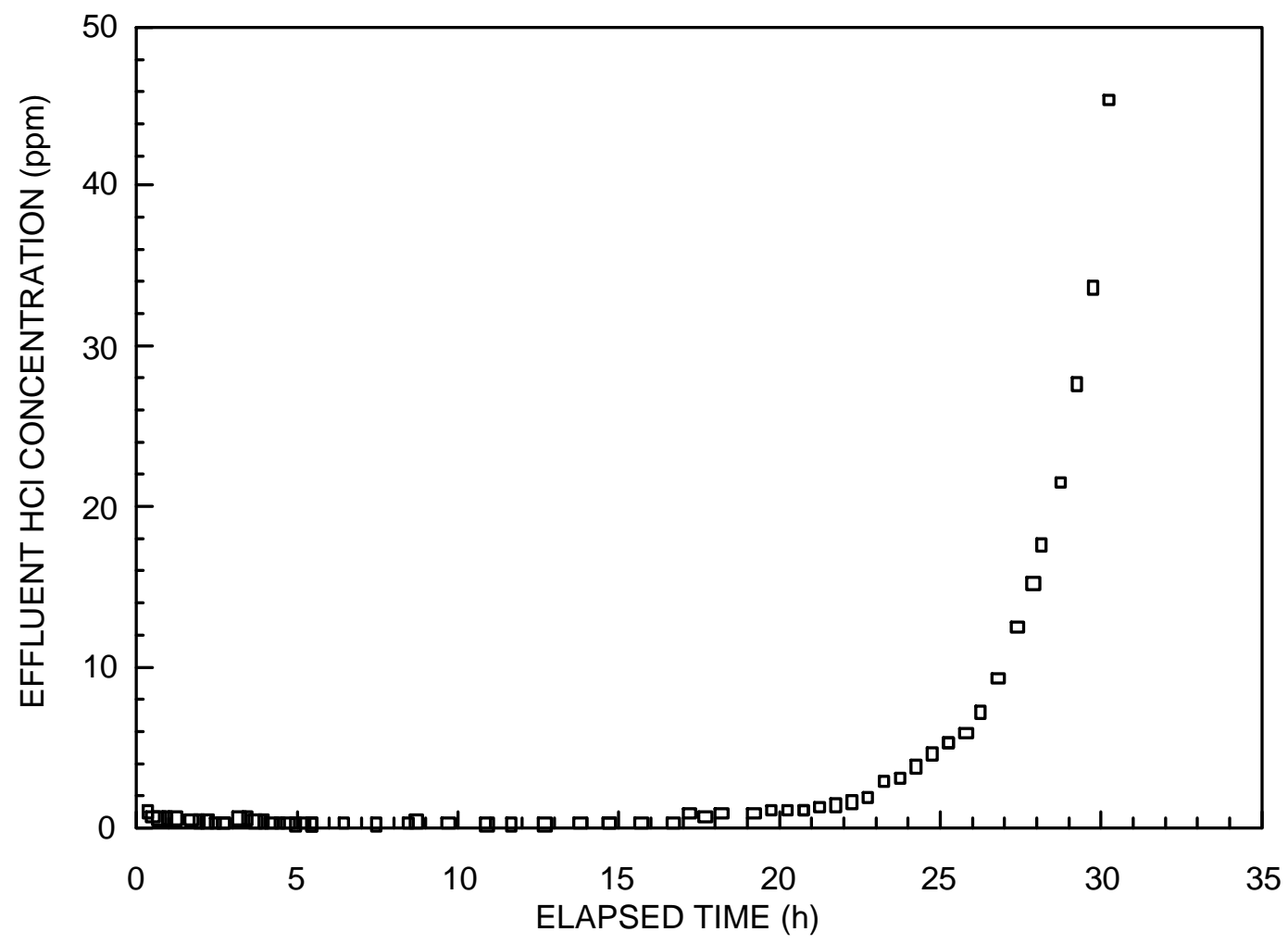

Figure 22. The $\mathrm{HCl}$ breakthrough curve for nahcolite sorbent pellets $(\mathrm{N}-08)$ at $500^{\circ} \mathrm{C}$. 
At the end of the $30 \mathrm{~h}$ run, samples were taken out of the sorbent bed at $1 \mathrm{~cm}$ intervals and were analyzed for their chloride content. The data shown in Figure 23 indicate that the chloride content decreased steadily along the length of the bed; the upstream end of the bed contained $25 \mathrm{wt} \%$ chloride while the downstream end had only $1.35 \mathrm{wt} \%$ chloride. These data indicated that the bench scale atmospheric pressure reactor was functioning properly and reliable data could be obtained.

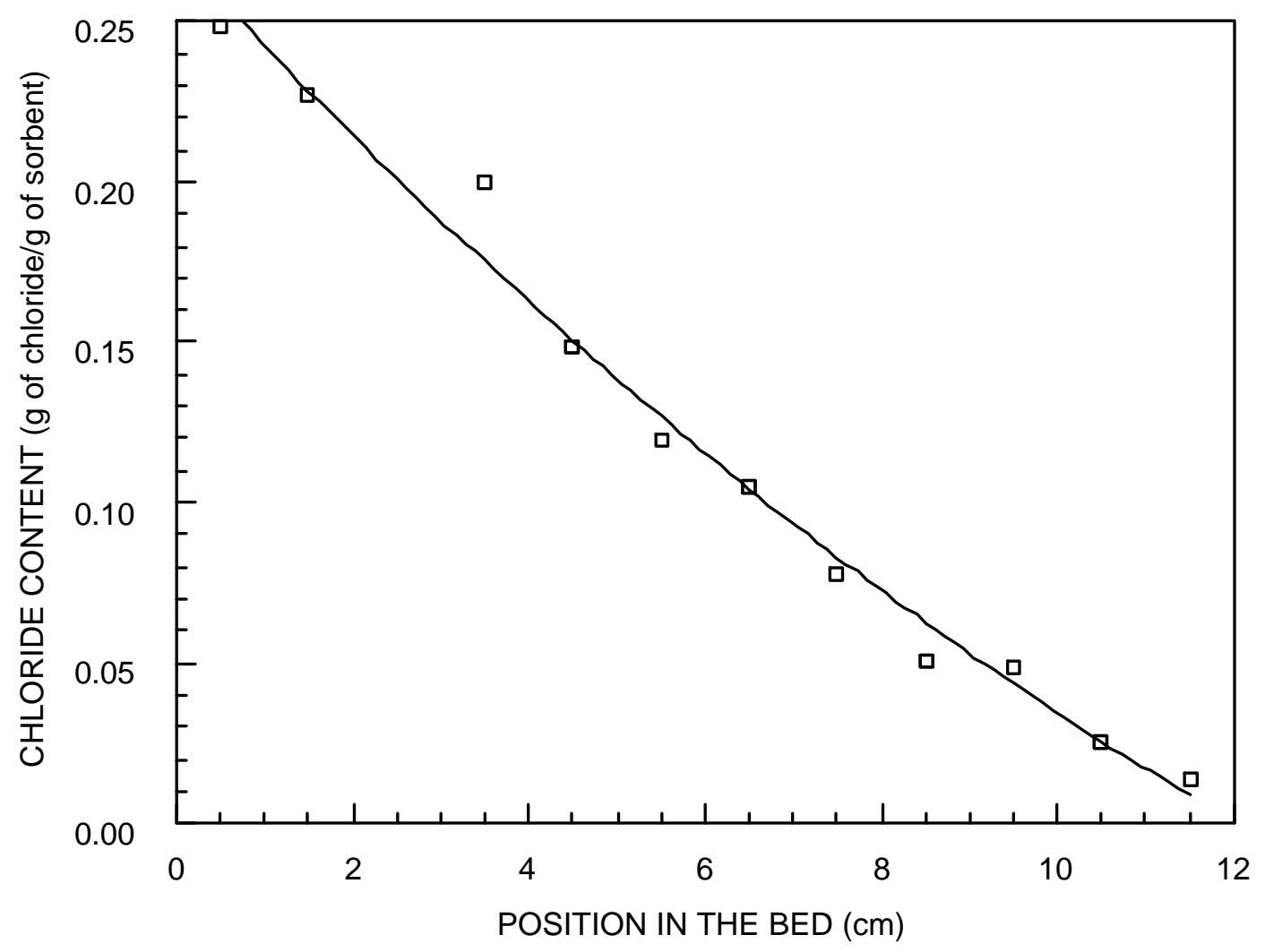

Figure 23. The variation of chloride content of $\mathrm{N}-08$ pellets after $30 \mathrm{~h}$ of reaction at $500^{\circ} \mathrm{C}$. 
Effect of Binder: The $\mathrm{HCl}$ uptake at $400^{\circ}$ and $500^{\circ} \mathrm{C}$ by L- 07 pellets $(10 \mathrm{wt} \%$ bentonite binder) was determined in the fixed-bed reactor at atmospheric pressure using a simulated Texaco coal gas stream containing no $\mathrm{H}_{2} \mathrm{~S}$. As shown in Figures 24, the $1 \mathrm{ppm}$ breakthrough occurred after $25 \mathrm{~h}$ at $400^{\circ} \mathrm{C}$. No $\mathrm{HCl}$ breakthorough was observed at $500^{\circ} \mathrm{C}$ even after $20 \mathrm{~h}$, at which point the test was terminated.

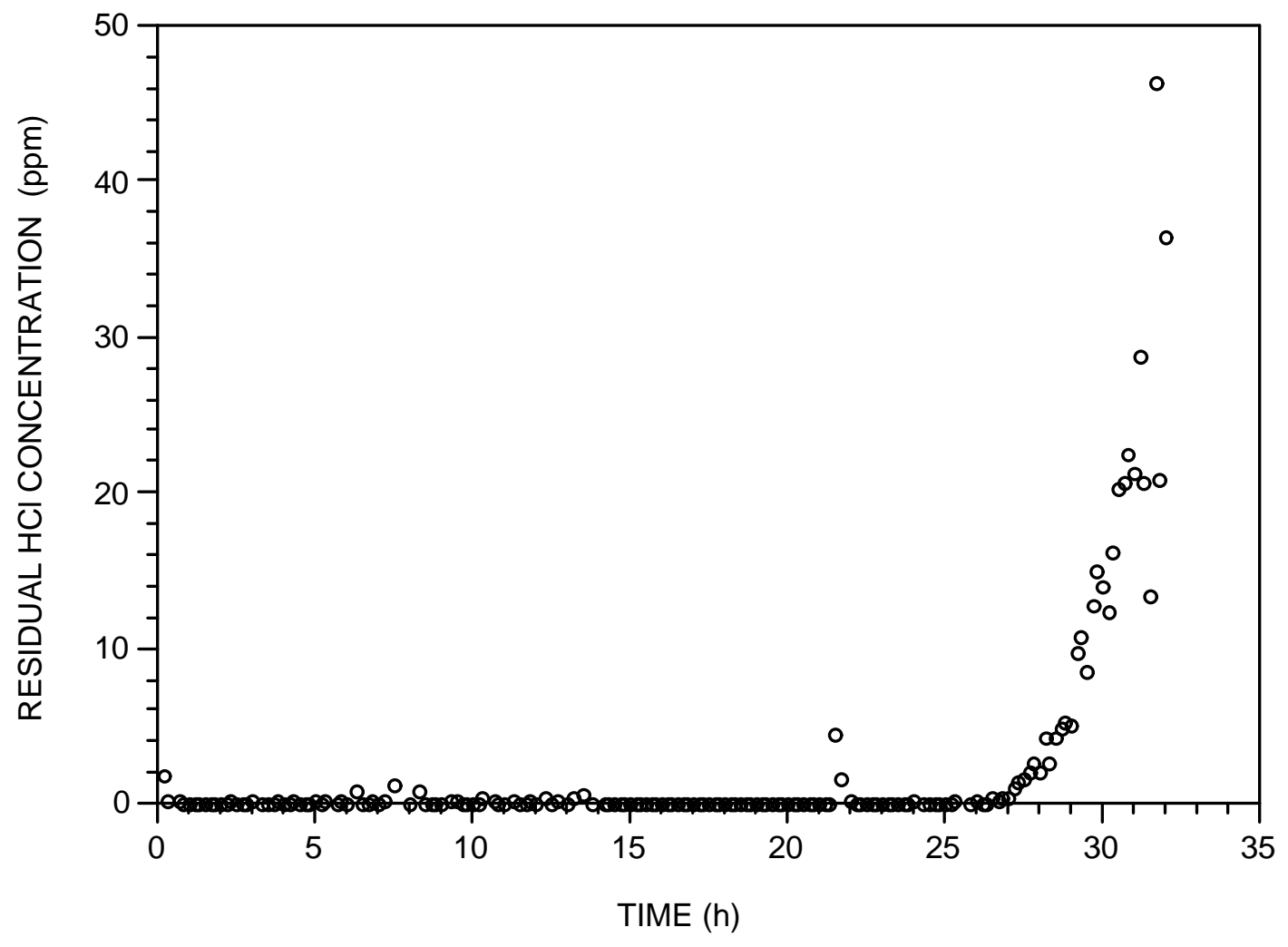

Figure 24 . The $\mathrm{HCl}$ breakthrough curve of L- 07 sorbent at $400^{\circ} \mathrm{C}$ in simulated coal gas containing no $\mathrm{H}_{2} \mathrm{~S}$. 
At the end of the runs, the pellets were taken out of the sorbent bed at about $1 \mathrm{~cm}$ intervals and were analyzed for their chloride content. The data, shown in Figure 25, indicate that the chloride loading at the upstream end of the bed reached a near saturation level at $400^{\circ}$ and $500^{\circ} \mathrm{C}$. At the downstream end, the observed chloride loadings were nearly similar at both temperatures. The chloride uptake in the intermediate layers was significantly higher in the run at $500^{\circ} \mathrm{C}$ in comparison with the run at $400^{\circ} \mathrm{C}$, which would be expected.

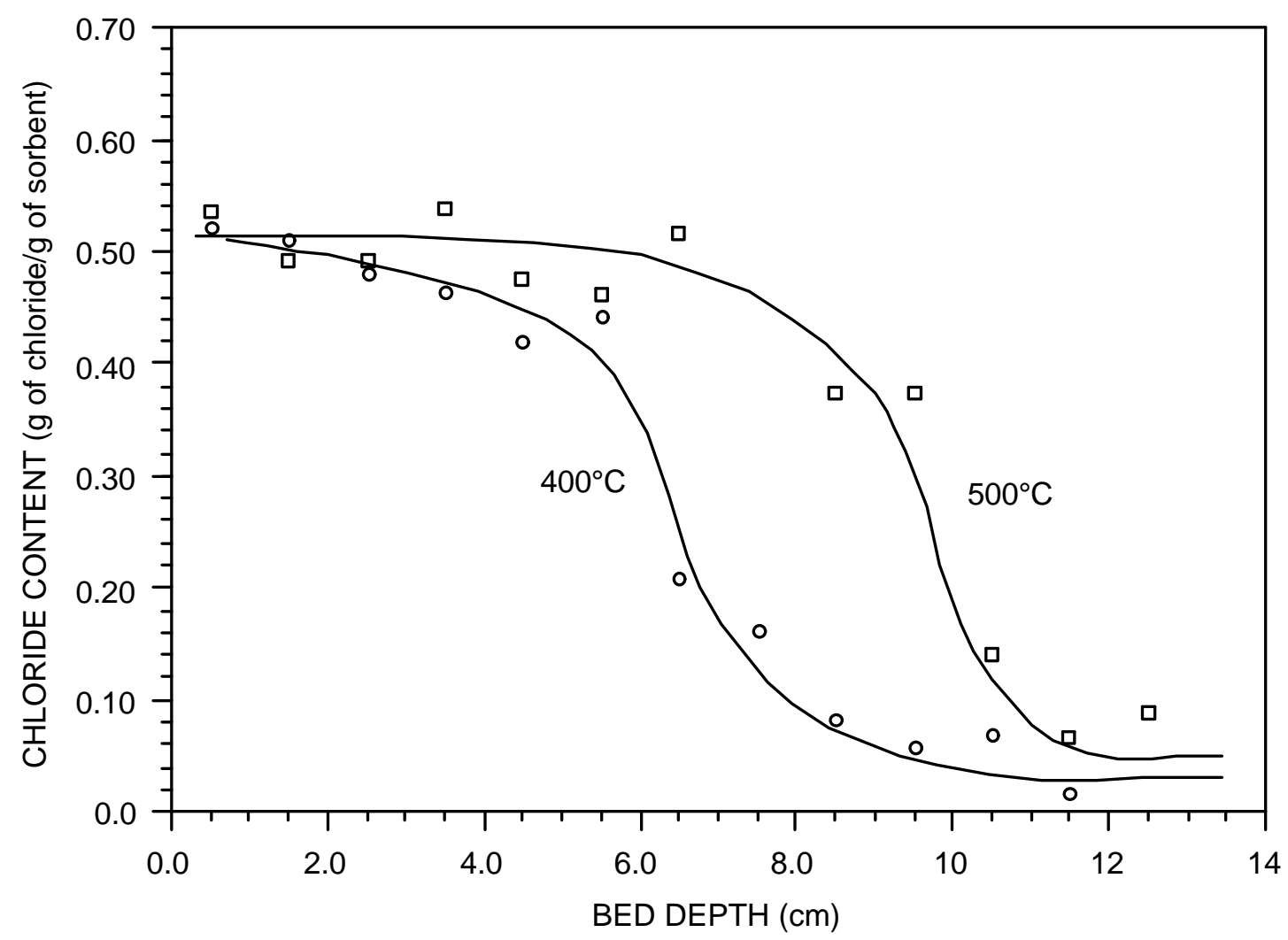

Figure 25. Variation of chloride content of spent L-07 sorbent pellets as a function of bed depth.

The $\mathrm{HCl}$ uptake at $400^{\circ}$ and $600^{\circ} \mathrm{C}$ by L-10 pellets (made with $5 \mathrm{wt} \%$ sodium silicate as binder) was determined in the fixed-bed reactor at atmospheric pressure using simulated GPIF gas stream containing no $\mathrm{H}_{2} \mathrm{~S}$ (Figure 26). No significant difference in the $\mathrm{HCl}$ breakthrough curves was observed. 


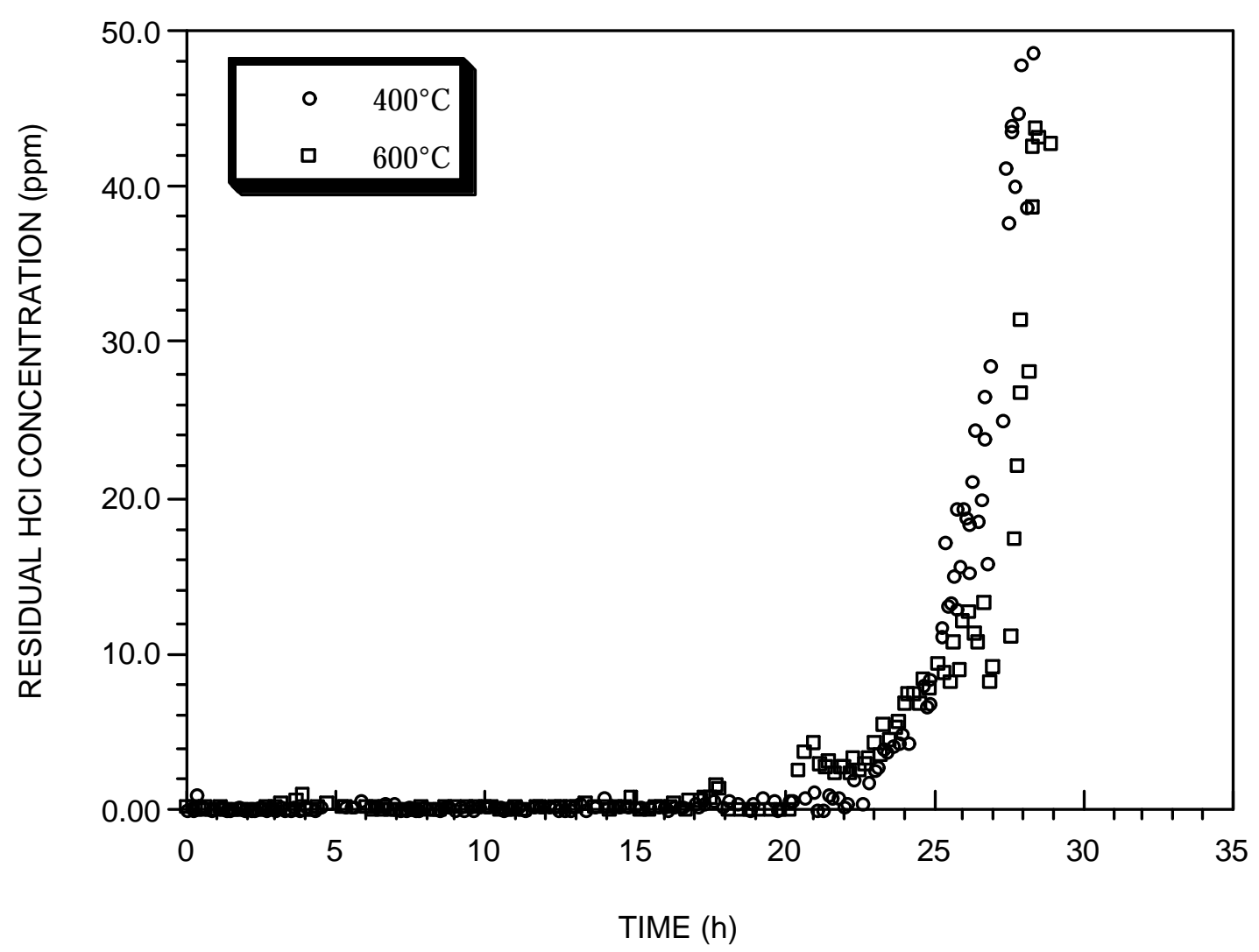

Figure 26. The $\mathrm{HCl}$ breakthrough curve of $\mathrm{L}-10$ sorbent at $500^{\circ}$ and $600^{\circ} \mathrm{C}$ in simulated GPIF coal gas containing no $\mathrm{H}_{2} \mathrm{~S}$.

As with L-07 sorbent runs, the L-10 pellets were also taken out of the sorbent bed at about $1 \mathrm{~cm}$ intervals and were analyzed for their chloride content. The data, shown in Figure 27, indicate that the chloride loading at the upstream end of the bed reached a near saturation level at $400^{\circ}$ and $600^{\circ} \mathrm{C}$. The saturation level is about $10 \%$ higher with the $\mathrm{L}-10$ pellets in relation to that observed with L-07 pellets. As discussed previously, the higher chloride capacities of sodium silicatebonded nahcolite pellets are attributed to the conversion of sodium sillicate binder to $\mathrm{NaCl}$. As with L-07 pellets, the observed chloride loadings with L-10 pellets were nearly similar at both temperatures at the downstream end. The chloride uptake in the intermediate layers was significantly higher at $400^{\circ} \mathrm{C}$ in comparison with the run at $600^{\circ} \mathrm{C}$. This observation is in contrast to the behavior observed with L-07 (bentonite-bonded) pellets. It was observed that at $600^{\circ} \mathrm{C}$ the pellets loosely stuck together forming soft aggregates and some gas channeling might have occurred. The cause of formation of the aggregates is believed to be softening of sodium silicate binder in the presence of steam at $600^{\circ} \mathrm{C}$. 


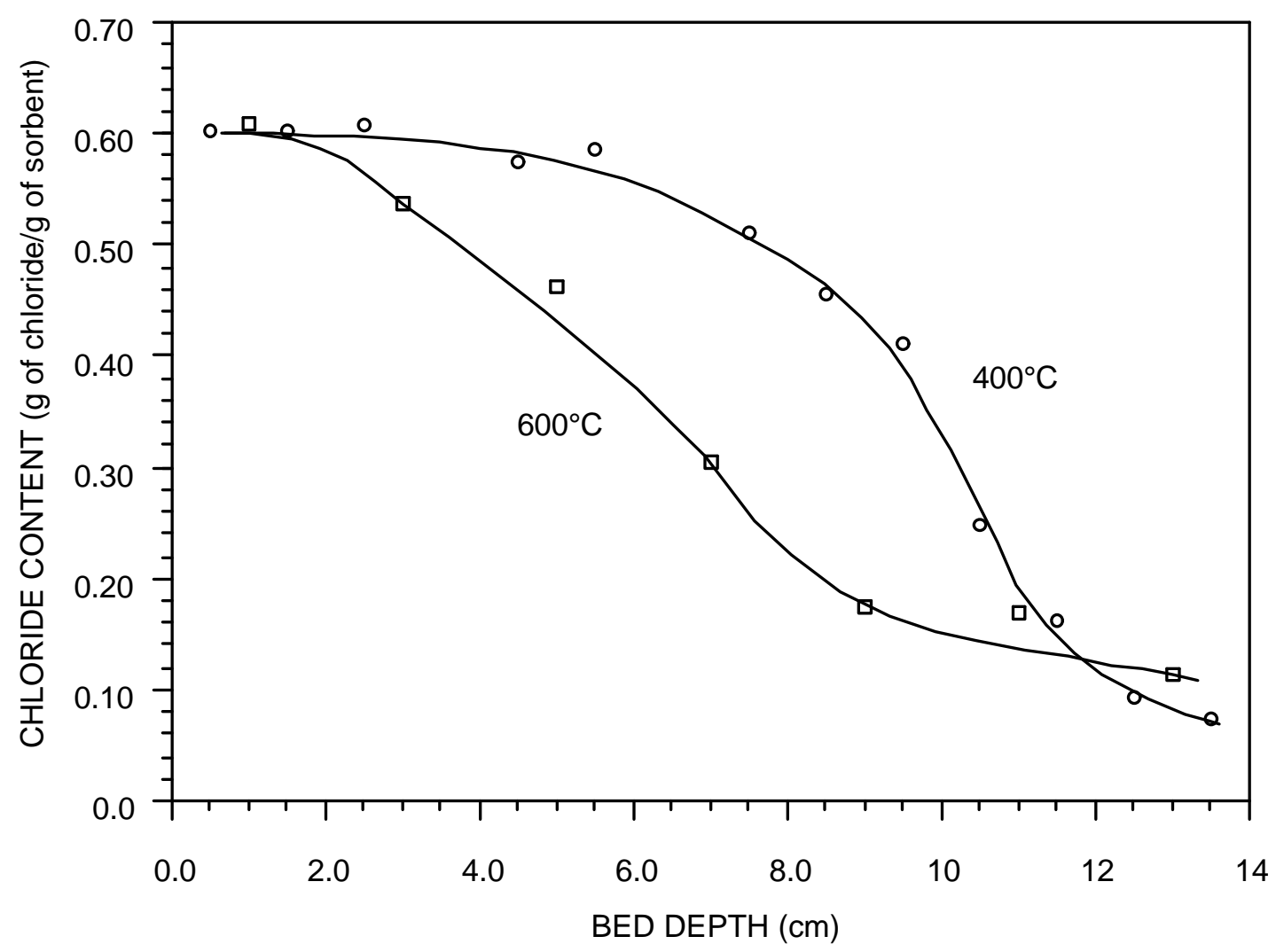

Figure 27. Variation of chloride content of spent L-10 sorbent pellets as a function of bed depth.

Effect of Pellet Size: In contrast to L-07 and L-10 pellets which were $3 \mathrm{~mm}$ in diameter, $\mathrm{L}-08$ pellets were $1.5 \mathrm{~mm}$ in diameter. A run was made with $\mathrm{L}-08$ pellets at $500^{\circ} \mathrm{C}$ to determine the effect of pellet size on the $\mathrm{HCl}$ removal efficiency of the nahcolite sorbent. The $\mathrm{HCl}$ breakthrough performance (Figure 28) and the chloride loading of the spent sorbent (Figure 29) show that the small pellet size increased the efficiency of $\mathrm{HCl}$ removal. The $1 \mathrm{ppm}$ breakthrough time for the $1.5 \mathrm{~mm}$ pellets was about $27 \mathrm{~h}$ in comparison to a time of $22 \mathrm{~h}$ for the $3 \mathrm{~mm}$ pellets (L-07 sorbent). With the small pellets, about $2 / 3$ of the bed was saturated with chloride whereas about $1 / 2$ of the bed was saturated with the large pellets. The increased chloride capture efficiency observed with small pellets can be explained by a decrease in the pore diffusion resistance. 


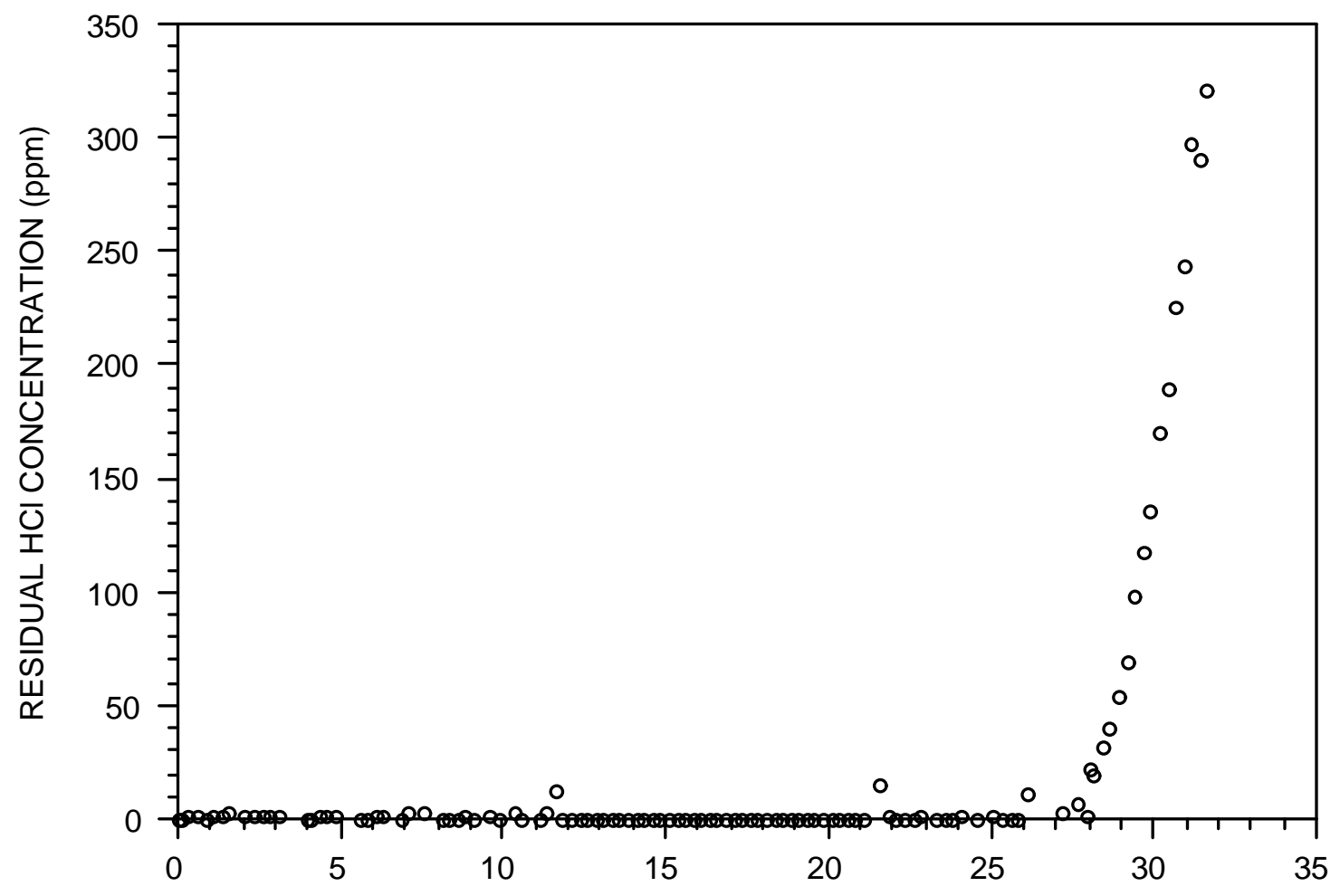

Figure 28. The $\mathrm{HCl}$ breakthrough curve of $\mathrm{L}-08$ sorbent at $500^{\circ} \mathrm{C}$ in simulated coal gas containing no $\mathrm{H}_{2} \mathrm{~S}$. 


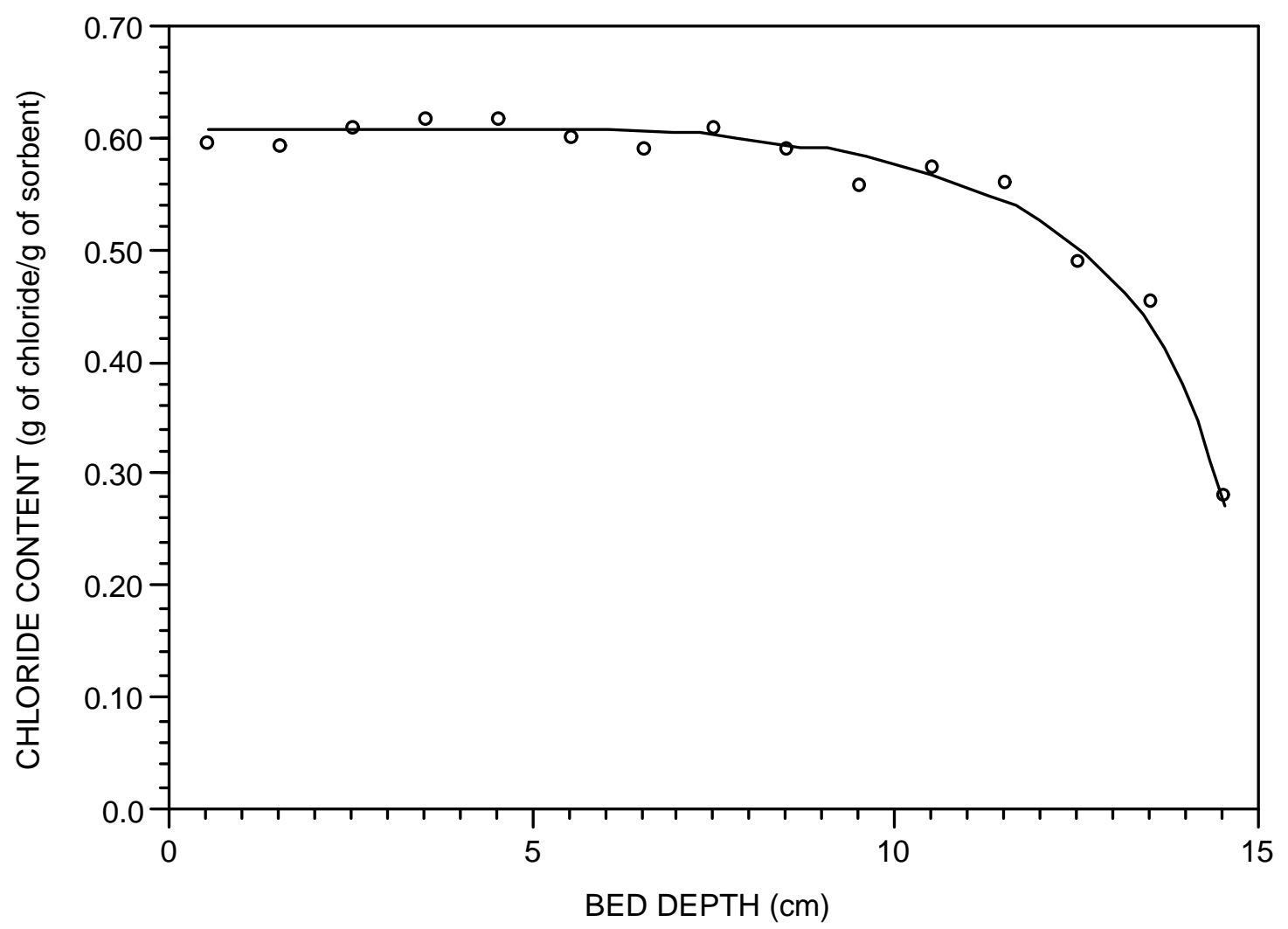

Figure 29. Variation of chloride content of spent L-08 $(1.5 \mathrm{~mm})$ sorbent pellets as a function of bed depth.

Effect of Hydrogen Sulfide in the Coal Gas: Initially, a TGA experiment was performed in which nahcolite powder $(<30 \mu \mathrm{m})$ was exposed to a $\mathrm{N}_{2}$ gas stream containing $0.5 \% \mathrm{H}_{2} \mathrm{~S}$. The results, shown in Figure 30, indicate that nahcolite was not very reactive toward $\mathrm{H}_{2} \mathrm{~S}$ at $550^{\circ} \mathrm{C}$. At the higher temperature of $650^{\circ} \mathrm{C}$, a slow reaction between nahcolite and $\mathrm{H}_{2} \mathrm{~S}$ was observed.

The $\mathrm{HCl}$ uptake by $\mathrm{L}-07$ pellets in the temperature range $400^{\circ}$ to $600^{\circ} \mathrm{C}$ at atmospheric pressure using simulated Texaco coal gas stream containing $3000 \mathrm{ppm}_{2} \mathrm{~S}$ (Figure 31). Although the presence of $\mathrm{H}_{2} \mathrm{~S}$ appears to reduce the time for $1 \mathrm{ppm} \mathrm{HCl}$ breakthrough, the temperature effect was only minor. The $\mathrm{HCl}$ breakthrough occurred slightly earlier at $600^{\circ} \mathrm{C}$ compared to the time observed at $400^{\circ} \mathrm{C}$. 


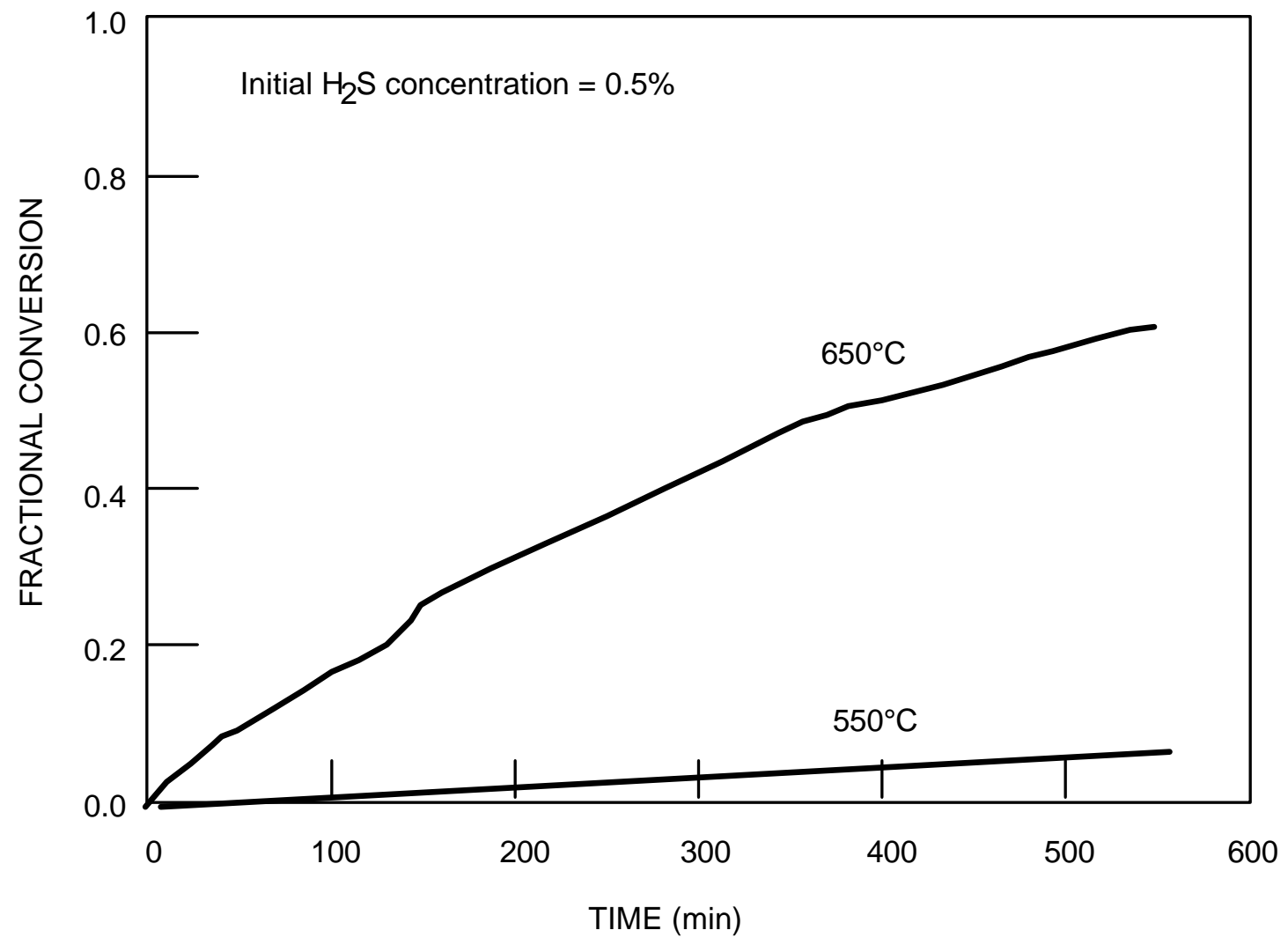

Figure 30. The reaction between nahcolite powder and hydrogen sulfide at $550^{\circ}$ and $650^{\circ} \mathrm{C}$. 


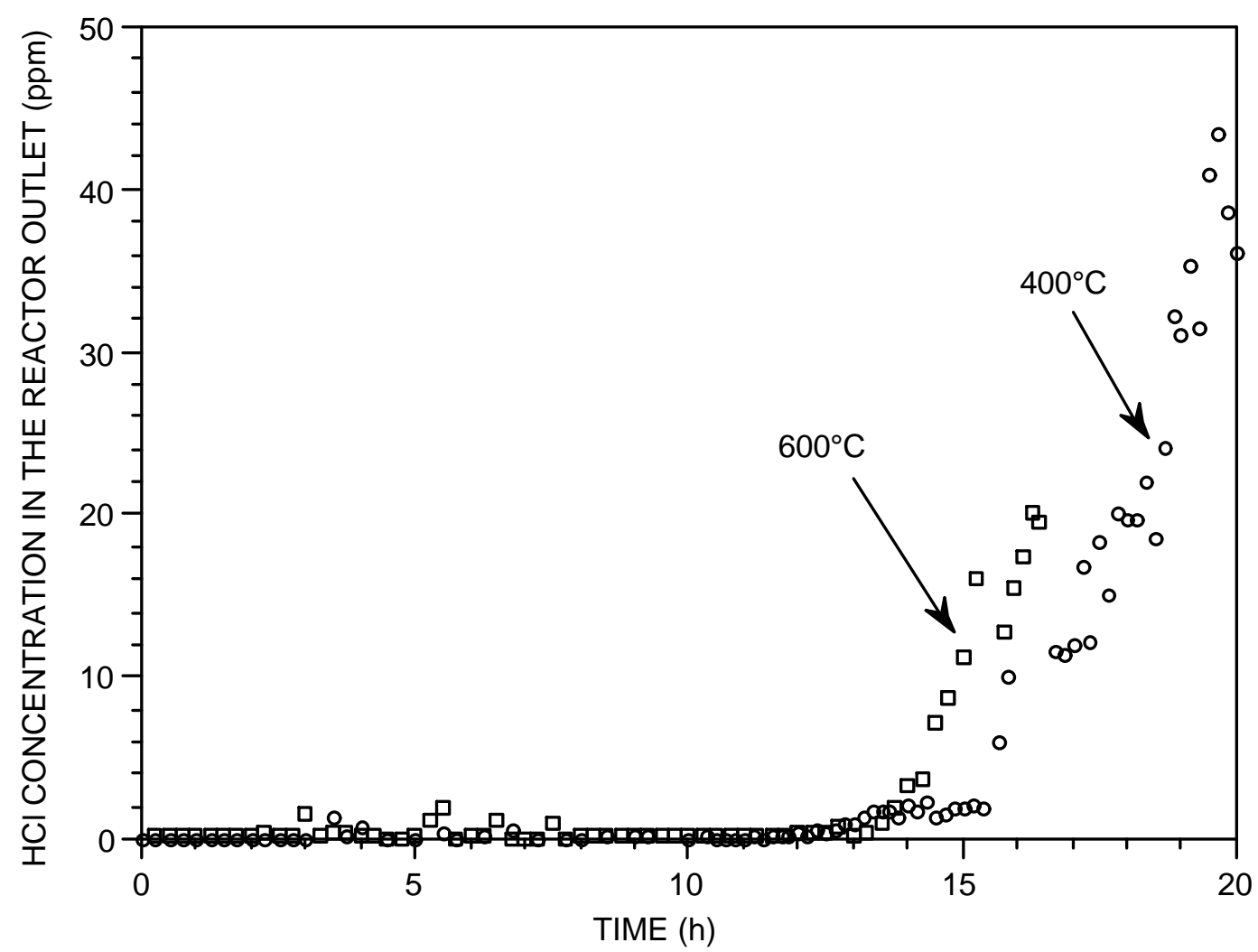

Figure 31. The $\mathrm{HCl}$ breakthrough curves with L-07 sorbent at $400^{\circ}$ and $600^{\circ} \mathrm{C}$ in the presence

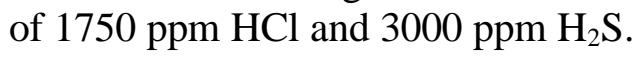

The profile of chloride accumulated on the sorbent pellets as a function of the bed depth is shown in Figure 32. Note that the pellets at the upstream end of the bed were nearly saturated with the chloride. The chloride loading at the bottom portion of the bed in the run at $400^{\circ} \mathrm{C}$ was rather low. However, at $600^{\circ} \mathrm{C}$, the chloride loading at the middle of the bed was comparable to that observed in the run with the coal gas that did not contain any $\mathrm{H}_{2} \mathrm{~S}$. 


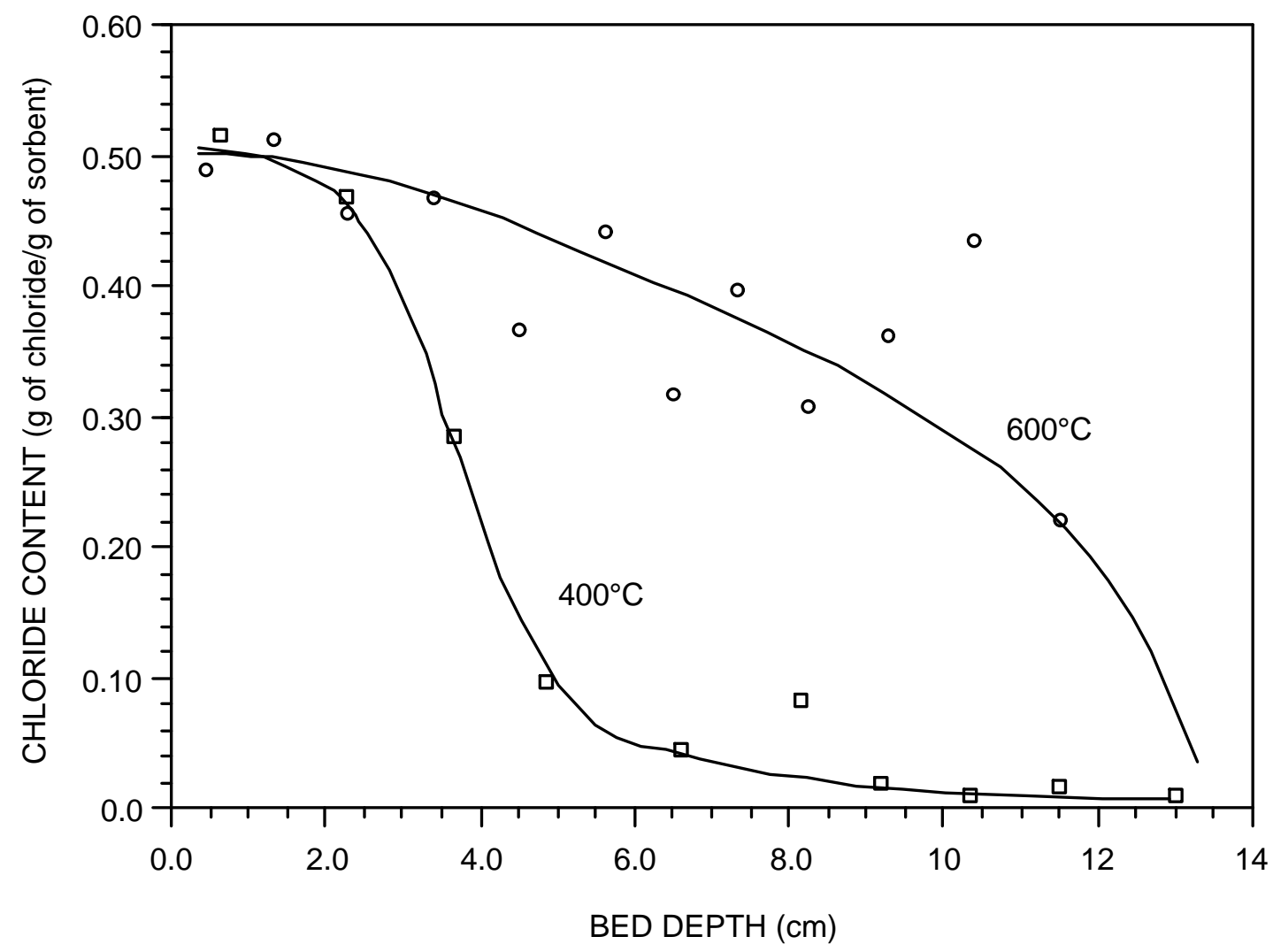

Figure 32. Variation of chloride content of spent L-07 sorbent pellets as a function of bed depth with a simulated coal gas containing $3000 \mathrm{ppm}_{2} \mathrm{~S}$.

A fixed-bed reactor experiment was conducted with $\mathrm{L}-07$ pellets at $600^{\circ} \mathrm{C}$ using a simulated coal gas (GPIF composition) containing $1700 \mathrm{ppm}$ of $\mathrm{HCl}$ vapor and $3000 \mathrm{ppm}$ of $\mathrm{H}_{2} \mathrm{~S}$. As with runs with no $\mathrm{H}_{2} \mathrm{~S}$, the steady-state value of $\mathrm{HCl}$ vapor in the reactor exit was less than 1 ppm. The $1 \mathrm{ppm}$ breakthrough occurred at about $13 \mathrm{~h}$, and the run was continued for another $4 \mathrm{~h}$ after the breakthrough time. Pellets from the top and bottom of the bed were analyzed for their chloride and sulfide contents. The pellets from the upstream end of the bed were nearly saturated with chloride $(50.5 \mathrm{wt} \%)$. The weight fraction of sulfide in the pellets varied from about $0.5 \mathrm{wt} \%$ at the upstream end to about $0.15 \mathrm{wt} \%$ at the downstream end. X-ray diffraction analysis also indicated that the pellets at the upstream end consisted of mainly $\mathrm{NaCl}$ and those at the downstream end consist of both $\mathrm{Na}_{2} \mathrm{CO}_{3}$ and $\mathrm{NaCl}$.

Effect of Pressure: The reactivity of the nahcolite sorbent at elevated pressures were tested in the HTHP fixed-bed reactor. About $210 \mathrm{~g}$ of L- 08 sorbent pellets ( $1.5 \mathrm{~mm}$ diameter) were loaded in the high pressure reactor and the bed was heated in nitrogen to a temperature of $500^{\circ} \mathrm{C}$. After the temperature was stabilized, a simulated Texaco coal gas stream was introduced and the pressure in the reactor was increased to $150 \mathrm{psig}$. When steady-state conditions were 
achieved, $1750 \mathrm{ppm}$ of $\mathrm{HCl}$ and $3000 \mathrm{ppm}$ of $\mathrm{H}_{2} \mathrm{~S}$ were added to the feed gas. The run was continued until $\mathrm{HCl}$ breakthrough was observed. At the end of the run, the reactor was depressurized and cooled to ambient temperature. The sorbent pellets were analyzed for their chloride content as a function of depth at about $1 \mathrm{~cm}$ intervals.

The $\mathrm{HCl}$ breakthrough results shown in Figure 33 illustrate that the pressure had a small effect on the sorbent reactivity. The average value of residual $\mathrm{HCl}$ concentration remained at about $1 \mathrm{ppm}$, although considerable scatter in the $\mathrm{HCl}$ concentration was observed. The breakthough occurred after about $21 \mathrm{~h}$, similar to runs at atmospheric pressures. The accumulated chloride profile as a function of bed depth is shown in Figure 34. The upper end of the bed was not completely saturated with chloride and the lower end of the bed was low in chloride content.

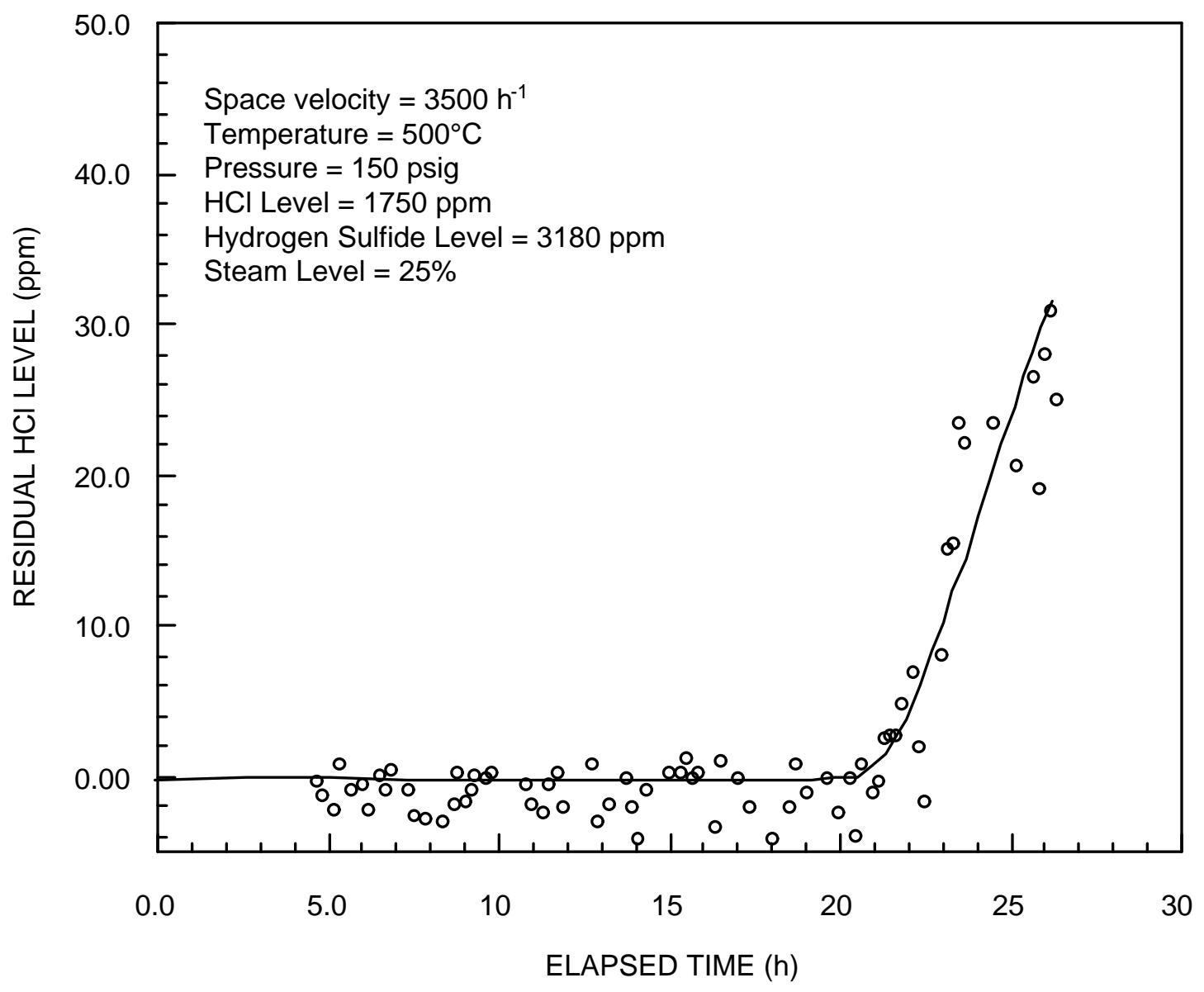

Figure 33. The $\mathrm{HCl}$ breakthrough curves with $\mathrm{L}-08$ sorbent at $550^{\circ} \mathrm{C}$ at $150 \mathrm{psig}$. 


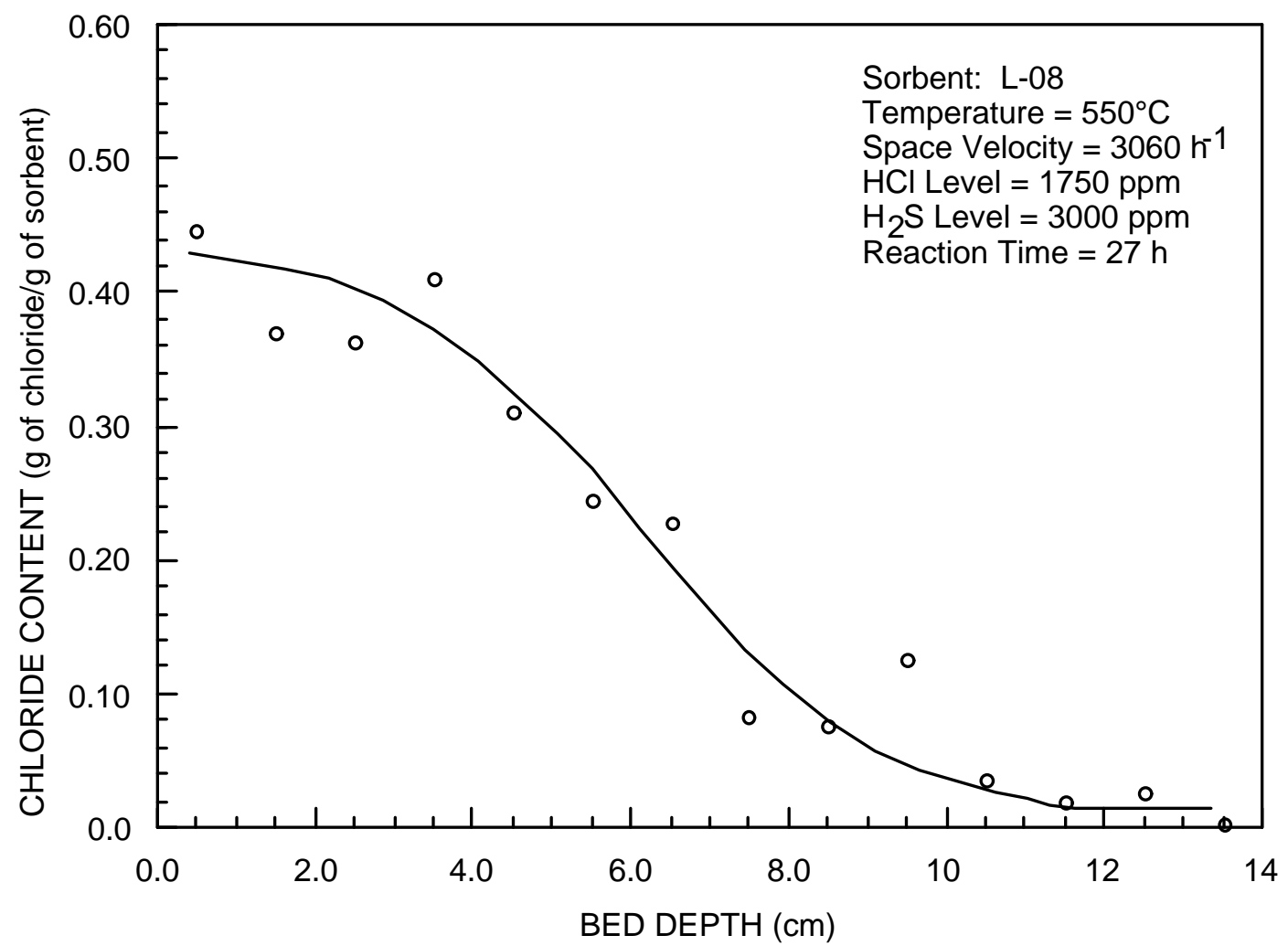

Figure 34. Variation of chloride content of spent L-08 sorbent pellets as a function of bed depth after reaction at $150 \mathrm{psig}$ with a simulated coal gas containing $3000 \mathrm{ppm}_{2} \mathrm{~S}$.

\section{Tests with Other Chloride Removal Sorbents}

Bench-scale fixed-bed reactor tests were conducted with trona ore obtained from North American Chemical Company. Trona is mined extensively in the United States for the manufacture of soda ash. The cost of $\mathrm{HCl}$ removal would be reduced significantly, if trona proves to be a suitable sorbent. A fixed-bed reactor test was conducted at $500^{\circ} \mathrm{C}$ with trona pellets. The trona ore was sieved to obtain -35 mesh powder $(<500 \mu \mathrm{m})$. The powder was mixed with $20 \mathrm{wt} \%$ bentonite and a small quantity of carboxy methyl cellulose and extruded into $6 \mathrm{~mm}$ pellets in a laboratory extruder. The pellets were dried overnight at $100^{\circ} \mathrm{C}$ and calcined at $500^{\circ} \mathrm{C}$ for $16 \mathrm{~h}$.

Figure 35 shows a comparison of $\mathrm{HCl}$ breakthrough data obtained with trona and nahcolite pellets at $500^{\circ} \mathrm{C}$ under similar conditions. The $1 \mathrm{ppm} \mathrm{HCl}$ breakthrough time was less than $2 \mathrm{~h}$ for trona pellets in comparison to about $12 \mathrm{~h}$ of nahcolite pellets. The surface area of calcined trona pellets were only $1 \mathrm{~m}^{2} / \mathrm{g}$ compared to a typical 2 to $3 \mathrm{~m}^{2} / \mathrm{g}$ observed for the nahcolite pellets. The difference in surface areas could be a reason for the low reactivity of trona compared to that of nahcolite. Note that $\mathrm{CO}_{2}$ evolution during heating of trona is only half of that for nahcolite; therefore, the anticipated porosity of trona-based materials could be significantly lower than that of 
nahcolite-based sorbents. The L-27 nahcolite pellet sorbents were made using an extruder that made pellets at a higher pressure than the extruder used to make L-01 through L-12 pellets. The L-27 pellets had a lower surface area and larger pores than L-08, L-10, or L-12 pellets. These characteristics made L-27 pellets less reactive than other pellet formulations.

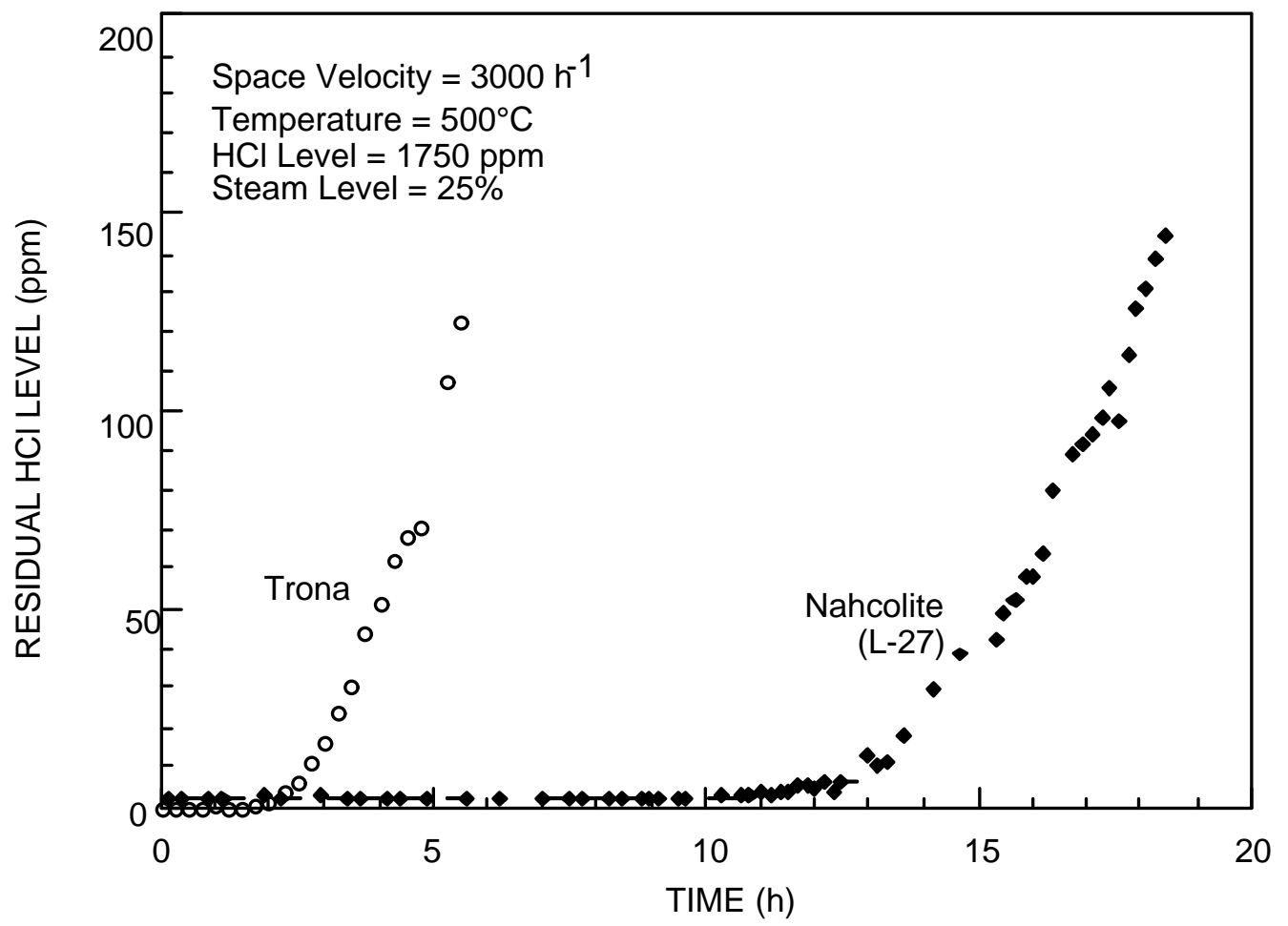

Figure 35. The $\mathrm{HCl}$ removal performance of trona vs nahcolite pellets at $500^{\circ} \mathrm{C}$ and 1 atm.

RTI evaluated the performance of the commercially available UCI C125 chloride guard pellets and compared it with the nahcolite sorbent (L-27) pellets. The UCI C125 were extruded pellets of $4.5 \mathrm{~mm}$ in diameter and composed of $20 \% \mathrm{CaO}, 50 \% \mathrm{ZnO}$, and $30 \%$ binder. The tests were carried out at $482^{\circ} \mathrm{C}, 150 \mathrm{psig}$ (11.2 atm), and 20.9 SLM gas flow rate (corresponding to $4000 \mathrm{~h}^{-1}$ space velocity). The gas composition used was $67.7 \% \mathrm{~N}_{2}, 14.9 \% \mathrm{H}_{2} \mathrm{O}, 13.2 \% \mathrm{CO}_{2}, 3.8 \%$ $\mathrm{H}_{2}, 4189$ ppmv $\mathrm{H}_{2} \mathrm{~S}$, and 359 ppmv $\mathrm{HCl}$. 
Figure 36 shows the breakthrough profiles for both the sorbent pellets. The estimated chloride capture capacity at breakthrough $(1 \mathrm{ppmv} \mathrm{HCl})$ was $1.3 \mathrm{wt} \%$ for the UCI C125 pellets (breakthrough time is 270 minutes for $250 \mathrm{~g}$ loading) compared to $5.8 \mathrm{wt} . \%$ for the L-27 nahcolite pellets (breakthrough time is 330 minutes for $191 \mathrm{~g}$ loading). Therefore, the nahcolite pellets have more chloride capture capacity than the UCI C125 chloride guard pellets for hot coal gas $\mathrm{HCl}$ removal applications.

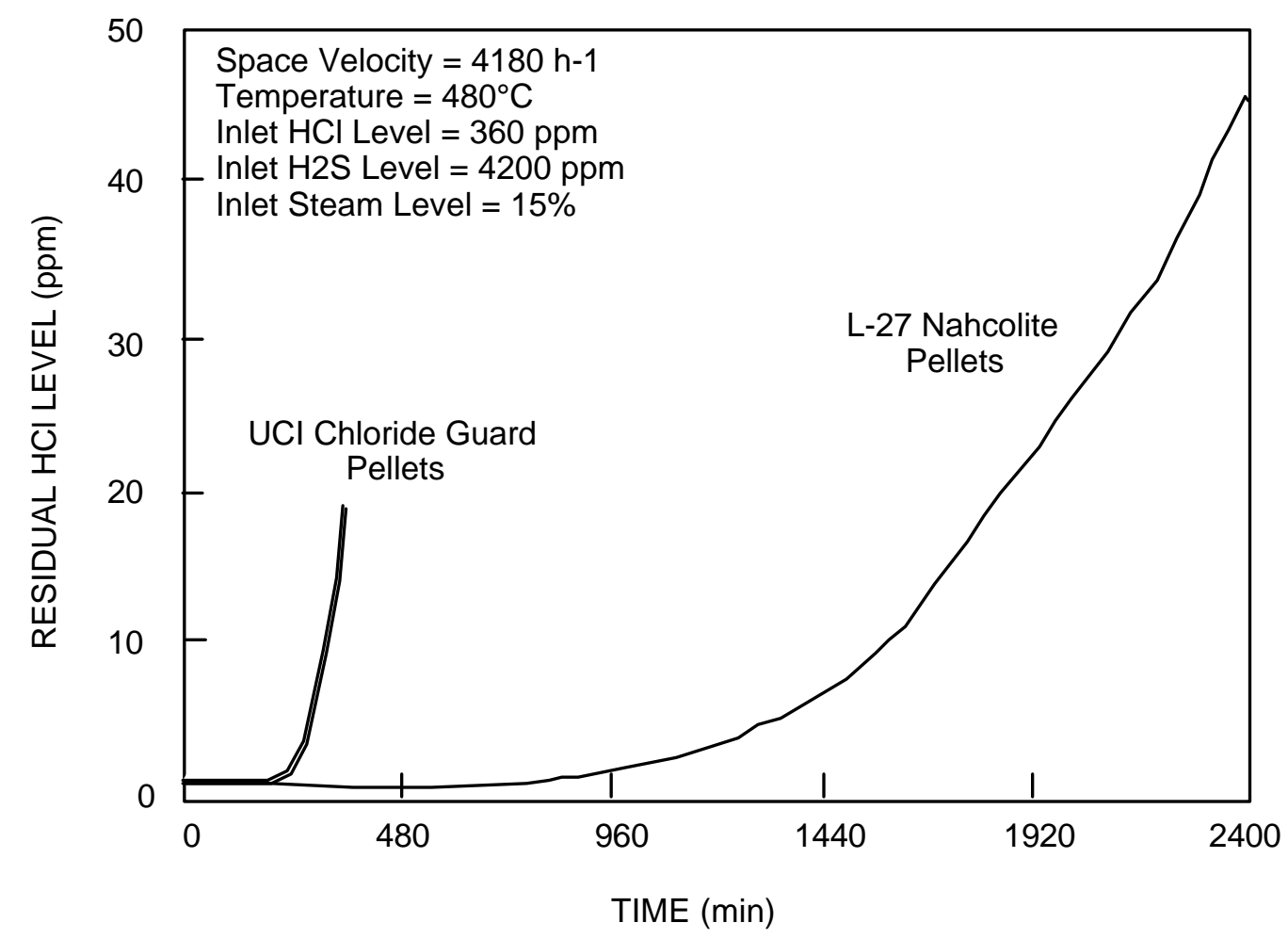

Figure 36. The $\mathrm{HCl}$ removal of performance of UCI Chloride Guard vs. nahcolite pellets.

The low chloride capacity with UCI C125 pellets could be due to the presence of $\mathrm{ZnO}$. At the operating conditions used in these tests, the $\mathrm{HCl}$ reacts with $\mathrm{ZnO}$ to form molten $\mathrm{ZnCl}_{2}$ on the pellet surface, which readily reacts with hydrogen sulfide to form an impervious layer of $\mathrm{ZnS}$ on the sorbent surface, preventing further diffusion of $\mathrm{HCl}$ into the pellet. However, the chloride capacity (5.8 wt\%) of the L-27 nahcolite pellets at $11.2 \mathrm{~atm}$ was lower than the near theoretical (about $50 \mathrm{wt} \%$ ) chloride capacity observed in the fixed-bed atmospheric pressure studies at SRI. The reason for the low chloride capacity became apparent when the spent sorbent bed in the reactor was found to be not uniform in color. Visual observation showed that a radial pattern 
existed in the spent sorbent bed; approximately half of the bed had black- and white-colored pellets and the other half had only white-colored, unreacted pellets. This radial pattern was consistent along the length of the bed. On breaking the black-colored pellets, white-colored unreacted material was observed, possibly indicating formation of a black product layer on the surface. Nonetheless, this test confirmed that nahcolite-based sorbents prepared under this program were superior to the commercial chloride guards at $550^{\circ} \mathrm{C}$ in simulated Texaco coal gas atmosphere.

\section{FLUIDIZED-BED REACTOR TESTS}

RTI investigated the use of raw nahcolite and other sorbents in both the atmospheric and high-pressure, bench-scale fluidized-bed reactor systems. In the atmospheric pressure tests, the bed height to diameter ratio was about 3. The minimum fluidization velocities $\left(\mathrm{U}_{\mathrm{mf}}\right)$ of the nahcolite sorbents were determined in the cold-flow fluidized-bed unit to be about 2 to $4 \mathrm{~cm} / \mathrm{s}$ at $25^{\circ} \mathrm{C}$ and $1 \mathrm{~atm}$, depending on the particle size of the sorbent.

\section{Influence of Sorbent Preparation Method on Chloride Capture Capacity}

A series of tests were carried out in the atmospheric pressure quartz reactor to compare the performance of various nahcolite sorbents. These tests were conducted at $550^{\circ} \mathrm{C}$ and a $\mathrm{U} / \mathrm{U}_{\mathrm{mf}}$ of 5.0 in a simulated Texaco coal gas (composition shown in Table 16) containing $1.125 \% \mathrm{H}_{2} \mathrm{~S}$, and 1750 ppmv HCl. The nahcolite sorbents tested were N-01 (90 to $300 \mu \mathrm{m}$ ), N-23 (90 to $300 \mu \mathrm{m}$ ), and NS-02 (75 to $150 \mu \mathrm{m})$. As noted earlier, NS-02 sorbent was a scaled-up version of NS-01 sorbent. The $\mathrm{U}_{\mathrm{mf}}$ varied between $1.75 \mathrm{~cm} / \mathrm{s}$ for the NS-02 sorbent and $2.5 \mathrm{~cm} / \mathrm{s}$ for N-01 and N-23 sorbents.

Figure 37 shows the $\mathrm{HCl}$ breakthrough curves for $\mathrm{N}-01, \mathrm{~N}-23$, and NS-02 sorbents. The calculated chloride capture capacity at $1 \mathrm{ppm}$ breakthrough was $9.8 \mathrm{wt} \%$ for $\mathrm{N}-01$ sorbent, $21 \mathrm{wt} \%$ for N-23 sorbent, and $26.8 \mathrm{wt} \%$ for NS-02 sorbent. Thus, the spray-dried (NS-02) sorbent exhibited a high chloride capacity compared to the raw mined $(\mathrm{N}-01)$ and granulated $(\mathrm{N}-$ 23) sorbents.

N-23 and NS-02 sorbents were made with bentonite binder which was expected to preserve the high surface area and porosity of the sorbent at elevated temperatures. The raw nahcolite powder sintered excessively resulting in a low chloride capacity. In addition, the high capacity of the NS-02 sorbent was due to its high surface area and porosity generated by the spray-drying technique. Table 17 lists the observed chloride capacity with corresponding values of surface area and porosities for the three formulations tested. 


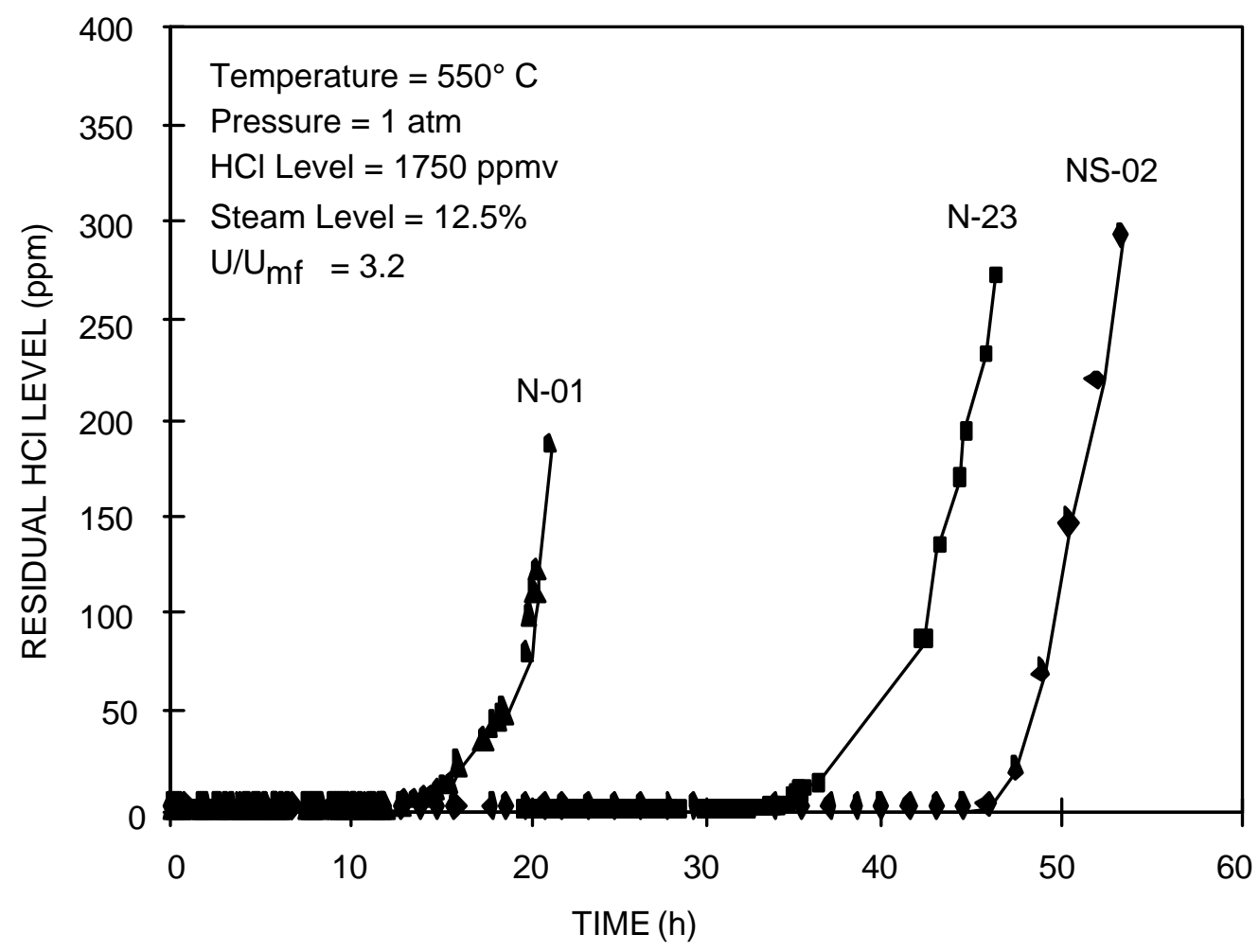

Figure 37. The $\mathrm{HCl}$ breakthrough curve for $\mathrm{N}-01, \mathrm{~N}-23$, and $\mathrm{NS}-02$ sorbents in a fluidized-bed reactor at $550^{\circ} \mathrm{C}$.

Table 17

CHLORIDE CAPACITY, POROSITY AND SURFACE AREA OF FLUIDIZED-BED SORBENTS

\begin{tabular}{lccc} 
Sorbent & $\begin{array}{c}\text { Chloride Capacity } \\
(\mathbf{w t . \% )}\end{array}$ & $\begin{array}{c}\text { Porosity } \\
(\boldsymbol{\%})\end{array}$ & Surface Area $\left(\mathbf{m}^{\mathbf{2}} / \mathbf{g}\right)$ \\
\hline N-01 & 9.8 & 8.2 & $<0.5$ \\
N-23 & 21.0 & 36.5 & 0.6 \\
NS-02 & 26.8 & 50.1 & 2.1 \\
\hline
\end{tabular}




\section{Influence of Fluidization Velocity}

Fluidized-bed reactor experiments were conducted to determine the effect of fluidization velocity with the raw nahcolite powder (N-01) and the spray-dried sorbent (NS-02). These tests were conducted at $550^{\circ} \mathrm{C}$ using simulated Texaco coal gas stream containing $1750 \mathrm{ppmv}$ of $\mathrm{HCl}$ and $1.125 \% \mathrm{H}_{2} \mathrm{~S}$. As shown in Table 18, the chloride capacity decreased with an increase in the gas velocity. Note that the spray-dried sorbent (NS-02) had a higher chloride capacity than did the raw powder $(\mathrm{N}-01)$.

\section{Table 18}

\section{CHLORIDE CAPACITY OF NS-02 and N-01 SORBENTS AS A FUNCTION OF GAS VELOCITY}

\begin{tabular}{ccc}
$\mathbf{U} / \mathbf{U}_{\mathbf{m f}}$ & Sorbent & Chloride Capacity (wt\%) \\
\hline 3 & $\mathrm{NS}-02$ & 38.0 \\
5 & $\mathrm{NS}-02$ & 26.8 \\
5 & $\mathrm{~N}-01$ & 9.8 \\
7.5 & $\mathrm{~N}-01$ & 0.6 \\
\hline
\end{tabular}

\section{High-Pressure Fluidized-Bed Reactor Tests}

Nahcolite, in the spray-dried formulation, was used in all high pressure tests because it had the maximum chloride capacity based on the atmospheric pressure tests. However, a limited number of tests were performed at elevated pressures with trona ore in the fluidized-bed reactor.

Trona Sorbent: The hygroscopic trona sorbent was dried at $120^{\circ} \mathrm{C}$ for $2 \mathrm{~h}$ and calcined at $482^{\circ} \mathrm{C}$ for $2 \mathrm{~h}$. The calcined trona sorbent was lightly ground and sieved to obtain a sample between the 100 and $350 \mu \mathrm{m}$ range. This trona sorbent was tested for its chloride capture capacity in the bubbling-bed mode at $482^{\circ} \mathrm{C}$ and $150 \mathrm{psig}$ (11.2 atm) at the same conditions used for NS-02 sorbent testing (24 SLM of gas flow, corresponding to $\mathrm{U} / \mathrm{U}_{\mathrm{mf}}=3$ ). The gas composition used was $11.4 \% \mathrm{CO}_{2}, 13 \%$ steam, $3.3 \% \mathrm{H}_{2}, 3641 \mathrm{ppmv} \mathrm{H}_{2} \mathrm{~S}, 312 \mathrm{ppmv} \mathrm{HCl}$, and balance $\mathrm{N}_{2}$. The test 
consisted of loading $120 \mathrm{~g}$ of calcined trona sorbent, heating the reactor with $\mathrm{N}_{2}$ purge to $482^{\circ} \mathrm{C}$, pressurizing the reactor to $150 \mathrm{psig}$, and then flowing the simulated coal gas with the desired composition. The $\mathrm{HCl}$ breakthrough $(>1 \mathrm{ppmv} \mathrm{HCl}$ ) was observed at about $675 \mathrm{~min}$ with trona sorbent compared to 330 min observed with NS-02 material (Figure 38). The estimated chloride capture capacities of the trona and NS-02 sorbent at breakthrough were $6.7 \mathrm{wt} \%$ and $3.2 \mathrm{wt} \%$, respectively, indicating that the trona sorbent could have a higher chloride capture capacity than NS-02 sorbent.

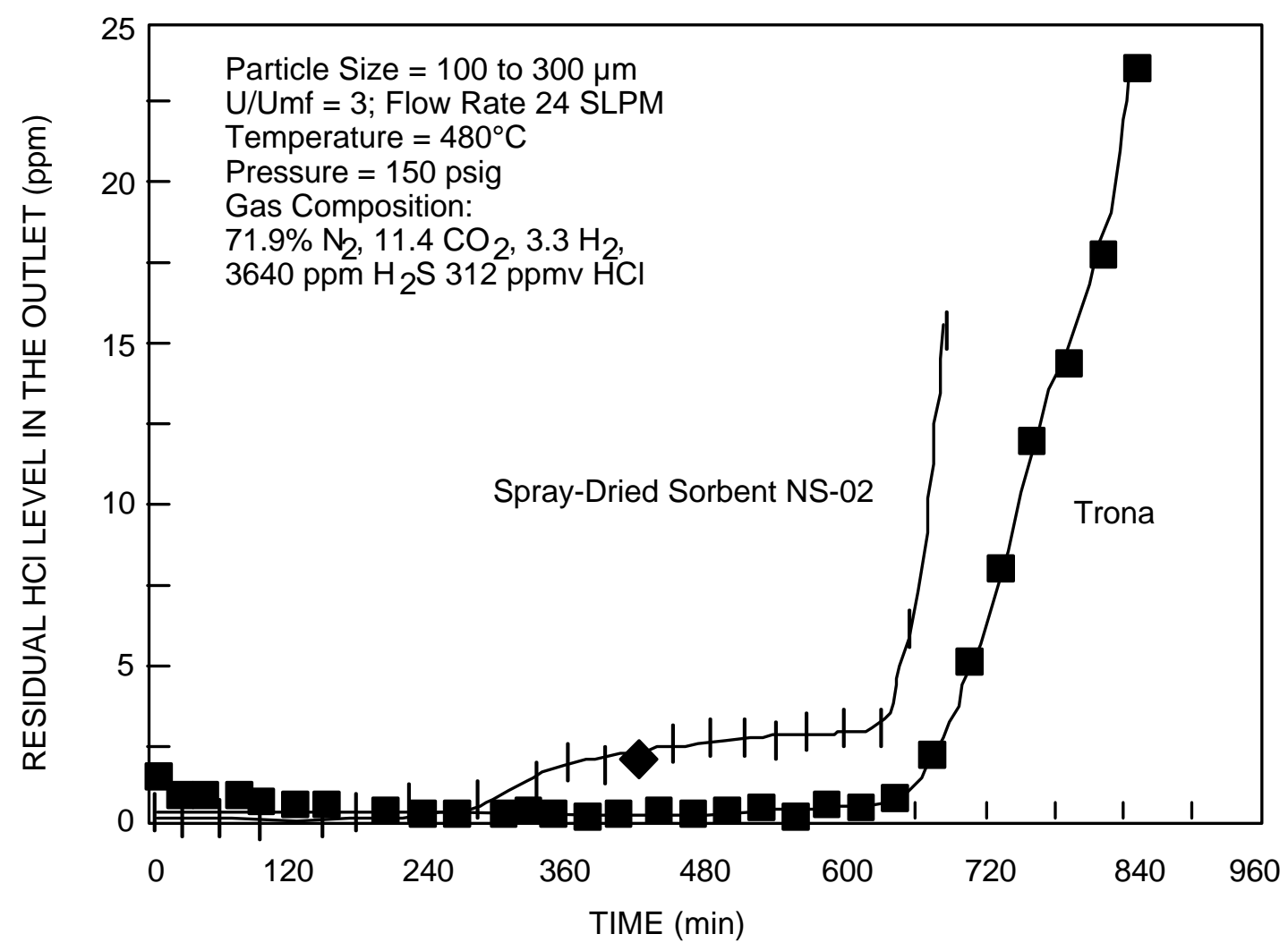

Figure 38. The $\mathrm{HCl}$ removal efficiency of trona compared to NS-02 sorbent.

Trona may not be a viable sorbent for $\mathrm{HCl}$ capture in spite of the fact that it might have a higher chloride capture capacity than the nahcolite-based (NS-02) sorbent. The presence of iron pyrite $\left(\mathrm{FeS}_{2}\right)$ impurity in trona would produce $\mathrm{H}_{2} \mathrm{~S}$, consuming valuable hydrogen in the coal gas. The amount of pyrite present in trona varies substantially from mine to mine. Removal of iron pyrites from trona would increase its cost, negating the primary reason for the use of trona instead of nahcolite. Furthermore, in the experiments with trona, a yellow precipitate was observed in the steam condenser, perhaps indicating the formation of iron chloride. 


\section{Effect of Pressure on HCl Removal by Nahcolite Sorbent NS-02}

Two tests were carried out at $482^{\circ} \mathrm{C}$ and $150(11.2 \mathrm{~atm})$ and $280 \mathrm{psig}(20 \mathrm{~atm})$ pressures using the same superficial gas velocity in both the cases corresponding to a $\mathrm{U} / \mathrm{U}_{\mathrm{mf}}$ of about 3 (24 slpm gas flow at $150 \mathrm{psig}$ and $45.1 \mathrm{slpm}$ at $280 \mathrm{psig}$ ). The gas composition used was $71.8 \% \mathrm{~N}_{2}$, $13 \%$ steam, $11.4 \% \mathrm{CO}_{2}, 3.3 \% \mathrm{H}_{2}, 3641 \mathrm{ppmv}_{2} \mathrm{~S}$, and $312 \mathrm{ppmv} \mathrm{HCl}$. However, because of an inadvertent switch over of the mass flow controller used for $\mathrm{HCl}$ gas, the $\mathrm{HCl}$ concentration used in the 280 psig test was at $40 \mathrm{ppmv}$ instead of the desired $312 \mathrm{ppmv}$.

Figure 39 shows the $\mathrm{HCl}$ breakthrough profiles at 150 and 280 psig pressures. The estimated chloride capture capacity at breakthrough $(1 \mathrm{ppmv} \mathrm{HCl})$ is $3 \mathrm{wt} \%$ at $280 \mathrm{psig}$ (breakthrough time is $1290 \mathrm{~min}$ ) compared with $3.2 \mathrm{wt} . \%$ at $150 \mathrm{psig}$ (breakthrough time is $330 \mathrm{~min}$ ). Therefore, pressure does not appear to have any significant impact on the chloride capacity of the sorbent. The low chloride capacities at high pressures could be due to the low concentration of $\mathrm{HCl}$ vapor in the feed gas. It is suspected that some agglomeration of the sorbent particles and gas channeling might have occurred resulting in early breakthrough. The low chloride capacity could be also due to pore diffusion rate limiting at low concentrations of $\mathrm{HCl}$. At high concentrations, more chloride accumulates at the outer surfaces of the sorbent particles, thus increasing the total chloride capacity.

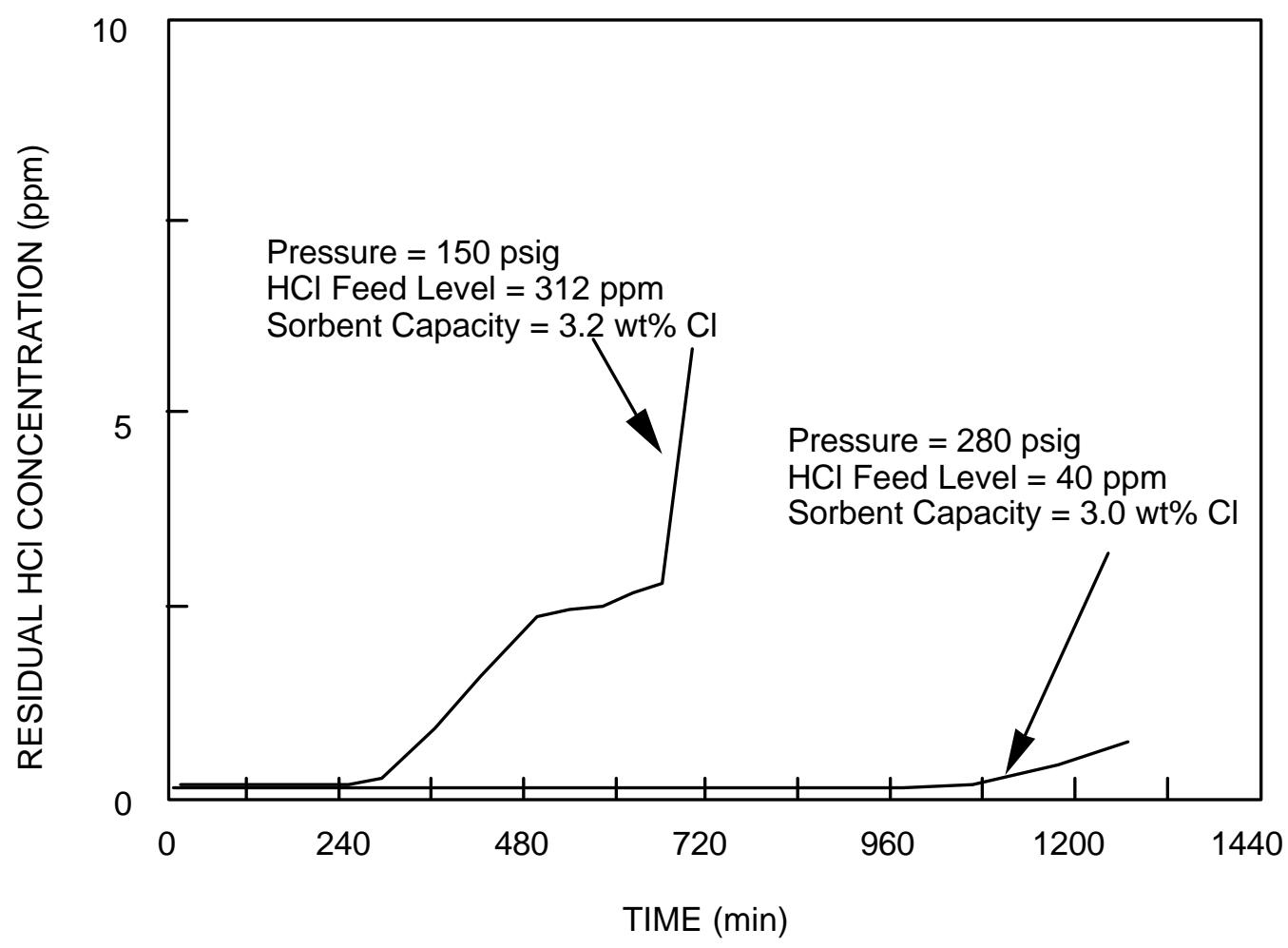

Figure 39. The effect of pressure on the $\mathrm{HCl}$ removal in the fluidized-bed reactor. 


\section{Effect of Steam Concentration}

The NS-02 sorbent was tested for chloride capture capacity in the bubbling-bed mode using $13 \%$ and $26 \%$ steam at $482^{\circ} \mathrm{C}$ and 150 psig using $24 \mathrm{SLM}$ of gas flow (corresponds to $\mathrm{U} / \mathrm{U}_{\mathrm{mf}}=3$ ). The gas composition used was $11.4 \% \mathrm{CO}_{2}, 3.3 \% \mathrm{H}_{2}, 3641$ ppmv $\mathrm{H}_{2} \mathrm{~S}, 312 \mathrm{ppmv} \mathrm{HCl}$, steam, and balance $\mathrm{N}_{2}$. The test consisted of loading $170 \mathrm{~g}$ of uncalcined NS-02 sorbent, heating the reactor with air purge to $482^{\circ} \mathrm{C}$ (to calcine the sorbent in air to burn the methocel), pressurizing the reactor to $150 \mathrm{psig}$, and then flowing the coal gas with the desired composition. At both steam concentrations, the $\mathrm{HCl}$ breakthrough (>1 ppmv $\mathrm{HCl}$ ) was observed at about 345 min (Figure 40). The estimated chloride capture capacity of the sorbent at breakthrough was $3.3 \mathrm{wt} \%$. for both the steam concentrations. Although the steam concentration did not influence the prebreakthrough performance of the sorbent, the breakthrough profile was different in both cases. A sharper breakthrough was observed at $26 \%$ steam level, whereas the breakthrough was gradual at $13 \%$ steam level.

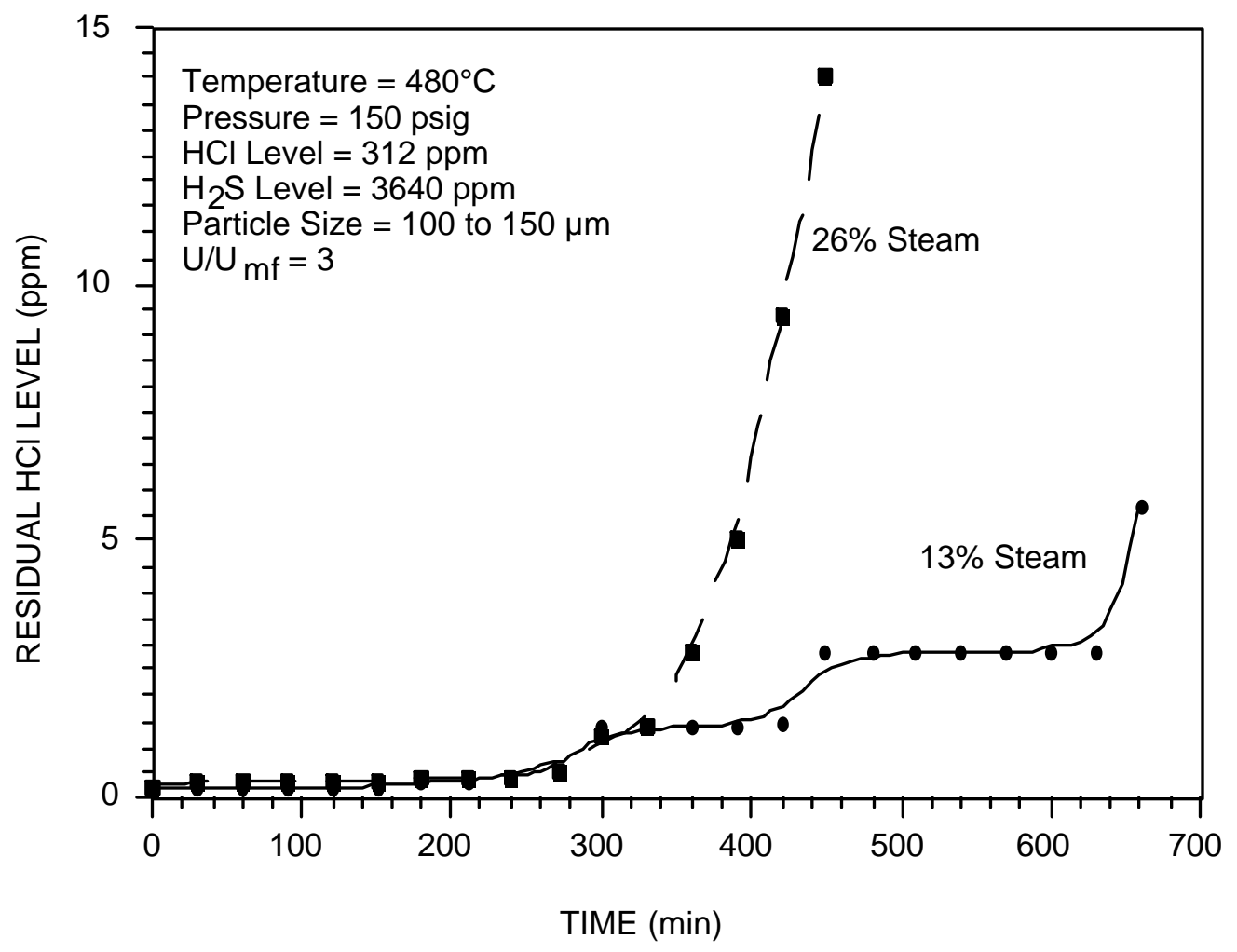

Figure 40. The effect of steam levels in the feed gas on the $\mathrm{HCl}$ removal efficiency of NS-02 sorbent. 
When the results from the HTHP tests were compared with atmospheric pressure test results, it became evident that the NS-02 sorbent exhibited poor capacity utilization at elevated pressures. This poor capacity utilization is believed to be due to caking and agglomeration of the sorbent in the reactor. Note that a high chloride capacity (35 wt\%) was found with this sorbent at the test in the GE-CRD pilot-plant unit operated under circulating-fluidized-bed conditions. Bed agglomeration is less likely at the high gas flows and sorbent circulation associated with the CFB operation than at the relativley low gas flows used for bubbling bed-operation. If this hypothesis was found to be true, using nahcolite sorbents in a fluidized-bed system operating in a bubblingmode may not be the best option.

\section{Atmospheric Entrained-Bed Studies}

Based on the differential reactor studies, the maximum capacity of the NS-02 sorbent (90 $180 \mu \mathrm{m}$ ) was about $38 \mathrm{wt} \%$ corresponding to a stoichiometric conversion of $\sim 75 \%$ ). Pilot-plant CFB testing with NS-02 sorbent ( 75 to $180 \mu \mathrm{m}$ ) also resulted in about $37.6 \mathrm{wt} \%$ capacity (71\% stoichiometric conversion) for the above size range. Bubbling fluidized-bed studies at atmospheric pressure also showed that the maximum capacity was $38 \mathrm{wt} \%$. These observations indicate that the low chloride capacity for NS-02 sorbent at elevated pressures could be due to either diffusion limitation through the $\mathrm{NaCl}$ product layer or due to agglomeration of sorbent particles leading to gas channeling. Use of small particle sizes under entrained-flow conditions would alleviate both of these problems. Hence, a limited number of tests were conducted with nahcolite sorbents in the size range between 45 and $90 \mu \mathrm{m}$ in an entrained-bed mode.

In this test, the gas velocity in the reactor was kept at a value less than the terminal velocity of the smallest particle to prevent elutriation since cyclones were not used downstream to catch small particles. The gas flow $(0.3 \mathrm{slpm})$ corresponded to a velocity of $2.9 \mathrm{~cm} / \mathrm{s}$ which was less than the terminal velocity $(4.9 \mathrm{~cm} / \mathrm{s})$ of the smallest particle $(45 \mu \mathrm{m})$. A typical experiment consisted of loading $79.3 \mathrm{~g}$ of uncalcined sorbent powder (corresponding to $50 \mathrm{~g}$ of calcined sorbent) and heating the reactor to $550^{\circ} \mathrm{C}$ under nitrogen. After $1 \mathrm{~h}$ of calcination at $550^{\circ} \mathrm{C}$, a flow of $0.3 \mathrm{SLM}$ of $2.1 \% \mathrm{HCl}$ in $\mathrm{N}_{2}$ was started.

Figure 38 illustrates the breakthrough curves for N-01 and NS-01 sorbents under the entrained-bed flow conditions. The times required for $1 \mathrm{ppm}$ breakthrough level were $43.5 \mathrm{~h}$ and $37.5 \mathrm{~h}$ for NS-01 and N-01 sorbent, respectively. The calculated chloride capacity at breakthrough time was $42.7 \mathrm{wt} \%$ and $52.1 \mathrm{wt} \%$ for N-01 and NS-01, respectively. At the breakthrough time, the conversion based on the estimated saturation capacity with NS-01 sorbent, was about $99 \%$ and 
for $\mathrm{N}-01$ sorbent it was $64 \%$. Thus, the spray-dried nahcolite sorbent achieves nearly complete capacity utilization, indicating high reactivity of NS-01 sorbent compared to N-01.

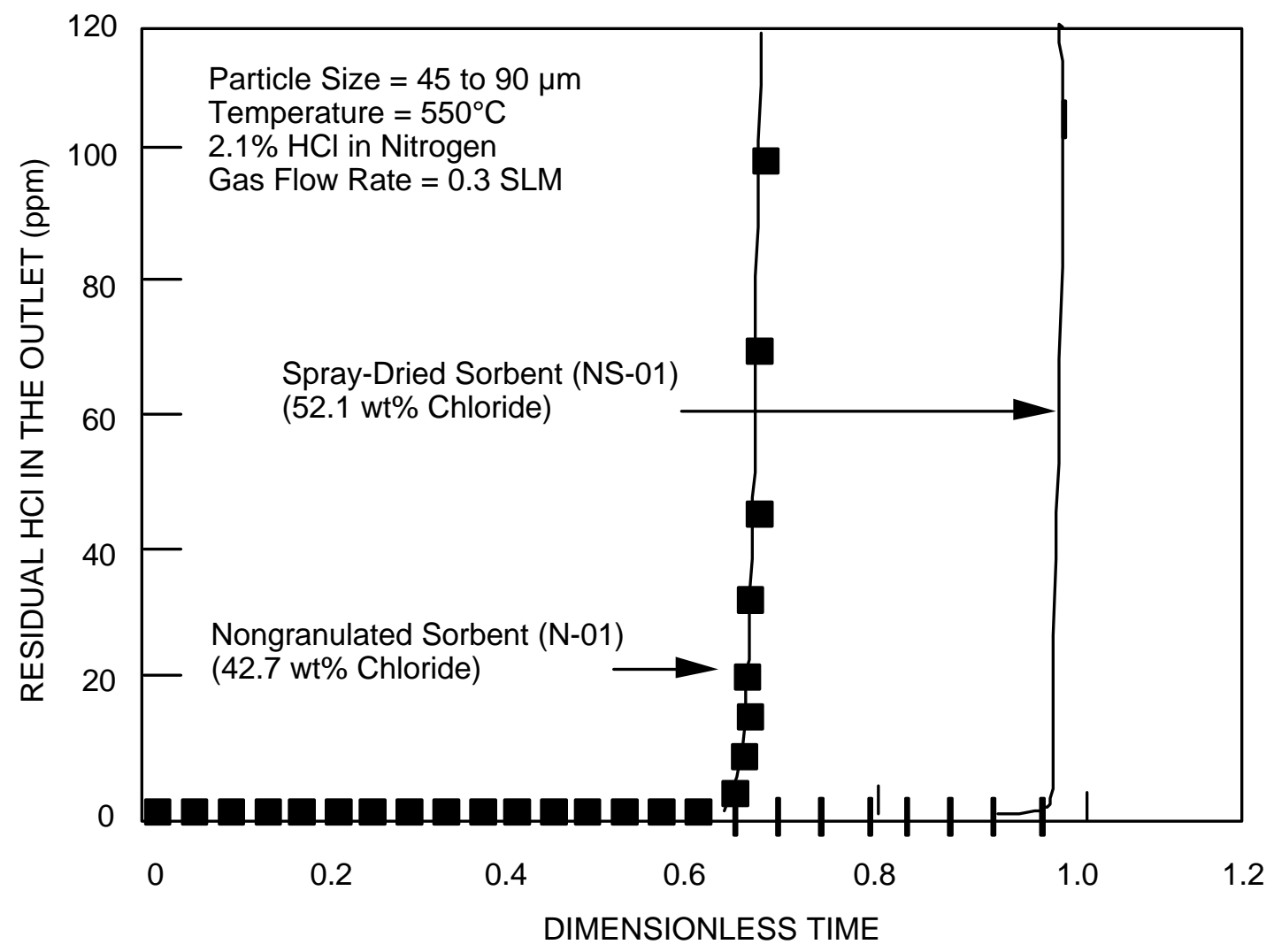

Figure 41. The $\mathrm{HCl}$ removal efficiency of nongranulated (N-01 and) spray-dried nahcolite (NS-01) sorbents in the entrained-bed reactor.

In the above experiments, the $\mathrm{HCl}$ vapor concentration was $2.1 \%$. To ensure that the high capacity was not due to the high $\mathrm{HCl}$ concentration used, a test was conducted with $\mathrm{N}-01$ sorbent at $550^{\circ} \mathrm{C}$ and a flow of $0.3 \mathrm{SLM}$ of $2000 \mathrm{ppmv} \mathrm{HCl}$ in Texaco coal gas composition with $12.4 \%$ steam was conducted. The time required for breakthrough $(>1 \mathrm{ppmv} \mathrm{HCl})$ was $452.5 \mathrm{~h}$. The calculated sorbent capacity was $51.6 \mathrm{wt} \%$ chloride at 1 ppmv breakthrough level and $52.2 \mathrm{wt} \%$ chloride at $10 \mathrm{ppmv} \mathrm{HCl}$ level in the effluent. For the same sorbent in $21,000 \mathrm{ppmv} \mathrm{HCl}$ in nitrogen atmosphere, the breakthrough time at 1 ppmv level was 35.7 hours and the sorbent capacity was $42.7 \mathrm{wt} \%$ (Table 19). These observations indicate that the reaction of $\mathrm{HCl}$ vapor with the nahcolite-based sorbents is first order with respect to $\mathrm{HCl}$ concentration in the gas. 
Table 19

\section{SORBENT CAPACITY OF N-01 SORBENT IN THE ENTRAINED-BED REACTOR MODE EXPERIMENTS}

\begin{tabular}{lccc} 
Gas composition & $\begin{array}{c}\mathrm{HCl} \text { concentration } \\
(\mathrm{ppmv})\end{array}$ & $\begin{array}{c}\text { Breakthrough time }^{1} \\
(\mathrm{~h})\end{array}$ & $\begin{array}{c}\text { Chloride Capacity } \\
(\mathrm{Wt} . \%)\end{array}$ \\
\hline Texaco coal gas & 2,000 & 452.5 & 51.6 \\
Nitrogen & 21,000 & 35.7 & 42.7 \\
& & & \\
& & & \\
${ }^{1}$ 1 ppm breakthrough level & & & \\
& Steam level $=12.5 \%$ &
\end{tabular}

\section{REACTIVITY OF MOVING-BED REACTOR SORBENTS}

SRI conducted fixed-bed reactor experiments at $1 \mathrm{~atm}$ pressure of $500^{\circ} \mathrm{C}$ with a sorbent (MM2) prepared by GE-CRD for moving-bed reactor application. About $210 \mathrm{~g}$ of MM2 pellets were placed in the 2-in. ID quartz reactor and was exposed to a gas stream containing $1750 \mathrm{ppm}$ $\mathrm{HCl}, 25 \% \mathrm{H}_{2} \mathrm{O}, 6 \% \mathrm{CO}_{2}$, and balance $\mathrm{N}_{2}$. As indicated in Figure 42, the initial $\mathrm{HCl}$ concentration in the reactor effluent was about $1 \mathrm{ppm}$. After 40 minutes of reaction, the residual $\mathrm{HCl}$ level increased to $4 \mathrm{ppm}$. The residual $\mathrm{HCl}$ level continued to increase with time and attained a value of about $1120 \mathrm{ppm}$ after about $2 \mathrm{~h}$.

The run was repeated again with a fresh sample of the MM2 pellets and the results were similar. The pellets after reaction for about $2 \mathrm{~h}$ were analyzed for their chloride content. Pellets from the upstream, middle, and downstream layers contained only $0.028,0.030,0.031 \mathrm{~g} \mathrm{Cl}$ per $\mathrm{g}$ of sorbent. Because of this low chloride capacity of these pellets, the $\mathrm{HCl}$ breakthrough was observed very early in the run. The low capacity could be due to the nature of the binder or the high calcination temperature, or the combination of both. 


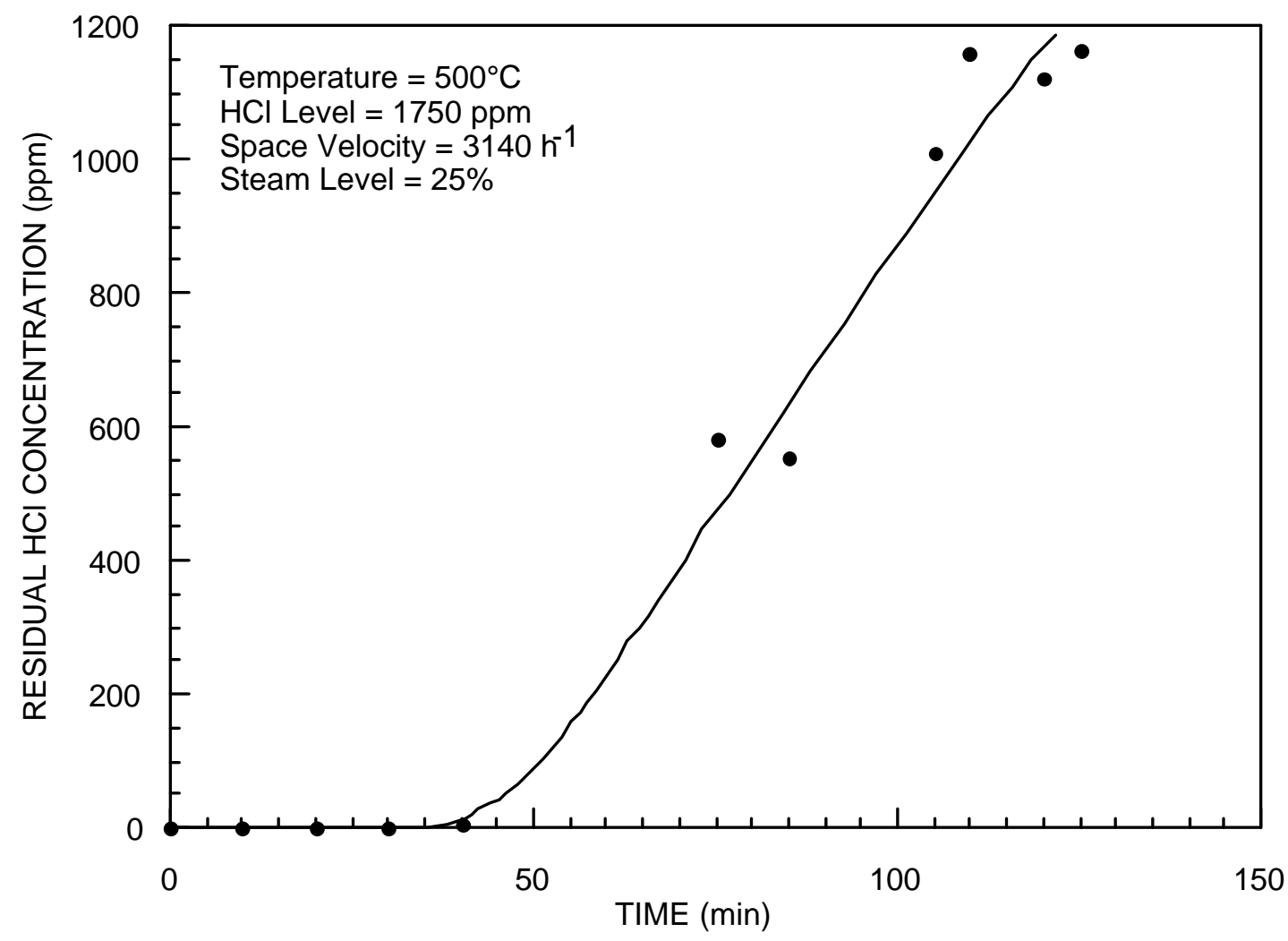

Figure 42. The $\mathrm{HCl}$ breakthrough curves with $\mathrm{MM} 2$ sorbent at $500^{\circ} \mathrm{C}$ in the presence of $1750 \mathrm{ppm} \mathrm{HCl}$. 


\section{DATA ANALYSIS}

\section{FIXED-BED REACTOR DATA}

The kinetics of $\mathrm{HCl}$ absorption by a fixed-bed of sorbent can be ascertained by the rise in outlet $\mathrm{HCl}$ concentration with time as breakthrough is reached or from the distribution of chloride along the axis of the bed after a period of exposure. A gradual $\mathrm{HCl}$ breakthrough and gently sloping profiles of absorbed $\mathrm{Cl}$ imply slow absorption kinetics, while a rapid $\mathrm{HCl}$ breakthrough and sharp absorbed $\mathrm{Cl}$ profiles indicate rapid absorption rates. To accurately determine rate constants from such integral reactor data, it is necessary to correctly define the rate laws with respect to local $\mathrm{HCl}$ concentration and local extent of sorbent conversion.

For the present analysis, it is assumed that the rate would be proportional to the partial pressure of $\mathrm{HCl}\left(\mathrm{P}_{\mathrm{HCl}}\right)$ and the local unconverted fraction of sorbent $(1-\mathrm{X})$, where $\mathrm{X}=\mathrm{S} / \mathrm{S}_{\mathrm{O}}$, the fractional conversion of sorbent and $\mathrm{S}$ and $\mathrm{S}_{\mathrm{O}}$ are the local amount of chloride sorbed and the maximum capacity of the sorbent in $\mathrm{g}$ of chloride per $\mathrm{g}$ sorbent, respectively. Thus, the local rate of $\mathrm{HCl}$ absorption and $\mathrm{NaCl}$ formation can be approximated by the expression,

$$
\text { Rate }(\mathrm{z})_{+\mathrm{Cl},-\mathrm{HCl}}=\left(\frac{\mathrm{Uo}}{\mathrm{RT}_{\mathrm{o}}}\right) \frac{\mathrm{dP}_{\mathrm{HCl}}}{\mathrm{dz}}=\mathrm{M}_{\mathrm{Cl}}^{-1} \rho_{\mathrm{S}} \mathrm{S}_{\mathrm{o}} \frac{\mathrm{dX}}{\mathrm{dt}}=\mathrm{kP}_{\mathrm{HCl}}(1-\mathrm{X}) \rho_{\mathrm{S}}
$$

Where: $\quad \mathrm{U}_{\mathrm{O}} \quad-\quad$ the superficial bed velocity for gas at $\mathrm{P}_{\mathrm{O}}$ and $\mathrm{T}_{\mathrm{o}}\left(\mathrm{cm}^{3}{ }_{\text {gas }} / \mathrm{cm}^{2}\right.$ reactor $\left./ \mathrm{h}\right)$

$\mathrm{z} \quad$ - $\quad$ the depth into the bed $(\mathrm{cm})$

$\rho_{\mathrm{s}} \quad$ - the bed density $\left(\mathrm{g}_{\mathrm{S}} / \mathrm{cm}^{3}\right.$ reactor $)$

$\mathrm{M}_{\mathrm{Cl}} \quad$ - the molecular weight of chlorine $(35.5 \mathrm{~g} / \mathrm{mol})$

$\mathrm{P}_{\mathrm{HCl}} \quad$ - the partial pressure of $\mathrm{HCl}$ at $\mathrm{z}$ (atm)

$\mathrm{X} \quad$ - the fractional conversion of sorbent to chloride at $\mathrm{z}$

$\mathrm{S}_{0} \quad$ - $\quad$ maximum capacity of the sorbent, $\mathrm{g} \mathrm{Cl} / \mathrm{g}$ sorbent

$\mathrm{k} \quad$ - the first order rate constant $\left(\mathrm{mol}_{\mathrm{Cl}} / \mathrm{g}_{\mathrm{sorb}} / \mathrm{atm}_{\mathrm{HCl}} / \mathrm{h}\right)$.

If $\mathrm{Y}_{\mathrm{HCl}}=\mathrm{P}_{\mathrm{HCl}} / \mathrm{P}_{0}$ where $\mathrm{P}_{0}=$ inlet concentration of $\mathrm{HCl}$ and equation (6) is solved, then:

$$
\mathrm{Y}_{\mathrm{HCl}}(\mathrm{z}, \mathrm{t})=\mathrm{Y}_{\mathrm{o}}\left|\frac{\exp \left(\frac{\mathrm{kP} \mathrm{Y}_{\mathrm{o}} \mathrm{t}}{\mathrm{S}_{\mathrm{o}} \mathrm{M}_{\mathrm{Cl}}^{-1}}\right)}{\mid \exp \left(\frac{\mathrm{kP} \mathrm{Y}_{\mathrm{o}} \mathrm{t}}{\mathrm{S}_{\mathrm{o}} \mathrm{M}_{\mathrm{Cl}}^{-1}}\right)+\exp \left(\frac{\mathrm{k} \rho_{\mathrm{S}} \mathrm{RT}_{\mathrm{o}} \mathrm{z}}{\mathrm{U}_{\mathrm{o}}}\right)-1}\right|
$$


and

$$
S(z, t)=\frac{S_{o} \exp \left(k P_{o} Y_{o} t / S_{o} M_{C l}^{-1}\right.}{\exp \left(k P_{o} Y_{o} t / S_{o} M_{C l}^{-1}+\exp \left(k \rho_{S} R T_{o} z / U_{o}\right)-1\right.}
$$

where $\mathrm{Y}_{\mathrm{O}}$ is the inlet fractional concentration of $\mathrm{HCl}$.

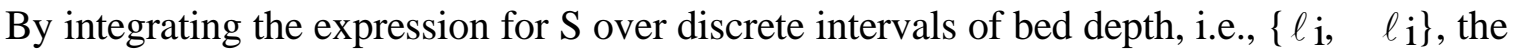
following equation (9) is derived:

$$
\mathrm{S}_{\mathrm{i}}(\mathrm{t})=\mathrm{S}_{\mathrm{o}}-\frac{\mathrm{S}_{\mathrm{o}}}{\lambda \Delta_{\ell}} \ln \left\lceil\frac{\exp \left(\lambda \ell_{\mathrm{i}}\right)+\exp (\alpha \mathrm{t})-1}{\exp \left(\lambda \ell_{\mathrm{i}-1}\right)+\exp (\alpha \mathrm{t})-1}\right]
$$

where: $\quad \lambda=\mathrm{k}_{\mathrm{s}} \mathrm{RT}_{\mathrm{o}} / \mathrm{U}_{\mathrm{O}}\left(\mathrm{cm}^{-1}\right)$

$\alpha=\mathrm{kP}_{\mathrm{O}} \mathrm{Y}_{\mathrm{o}} / \mathrm{S}_{\mathrm{O}} \mathrm{M}_{\mathrm{Cl}}^{-1}\left(\mathrm{~h}^{-1}\right)$

$\Delta_{\ell} \quad=\quad$ bed depth interval $(\mathrm{cm})$

Expression (9) for $S_{i}(t)$ is very similar to expression (8) for $S\left(z_{i}, t\right)$ with the substitution, $\mathrm{Z}_{\mathrm{i}}=\left(\ell_{\mathrm{i}}+\ell \mathrm{I}-1\right) / 2$. Nonlinear regression analysis was used to fit measured values of $\mathrm{Y}_{\mathrm{HCl}}(\mathrm{L}, \mathrm{t})$ and $\left\{\mathrm{S}_{\mathrm{i}}\left(\mathrm{t}_{\mathrm{f}}\right)\right\}$ where $\mathrm{L}$ is the total bed depth and $\mathrm{t}_{\mathrm{f}}$ is the total elapsed time of the integral fixed-bed, isothermal absorption reactor experiments.

The results of regression analysis using $\mathrm{Y}(\mathrm{HCl})$ data provided the statistically best estimates of $\alpha$ and $(\lambda L)$ given the values of $Y_{0}$. The regression analysis of measured chloride content of bed segments provided best estimates of $\lambda$, $\left(\alpha t_{f}\right)$, and $S_{o}$ from which the rate constant (k) can be calculated. For the solid samples,

$$
\alpha S_{\mathrm{o}} / \lambda=\frac{\mathrm{P}_{\mathrm{o}} \mathrm{U}_{\mathrm{o}} \mathrm{Y}_{\mathrm{o}} \mathrm{M}_{\mathrm{Cl}}}{\mathrm{RT}_{\mathrm{o}} \rho_{\mathrm{S}}}
$$

and self-consistency usually requires some adjustment of $\mathrm{Y}_{\mathrm{O}}$ to achieve a mass balance on the chloride content of the bed.

The rate constants calculated from the $\mathrm{HCl}$ breakthrough data and spent sorbent chloride analysis data differed, but within a factor of 2 , which is not unreasonable for this kind of model. The rate constants calculated from the results of various runs (Table 20) show little variation with temperature over the range from $400^{\circ}$ to $600^{\circ} \mathrm{C}$. Figures 43 and 44 show fitted curves for $\mathrm{Y}_{\mathrm{HCl}}$ $(14 \mathrm{~cm}, \mathrm{t})$ and $\left\{\mathrm{Si}_{\mathrm{i}}(30 \mathrm{~h})\right\}$ for an experiment with sample $\mathrm{L}-07$ at $500^{\circ} \mathrm{C}$. 
The calculated rate constants for pellets made with bentonite or sodium silicate binder are nearly the same. The low (nonexistent) apparent activation energy for absorption suggests that gas phase diffusion of $\mathrm{HCl}$, not solid-state diffusion of chloride through a porous $\mathrm{NaCl}$ film, limits the absorption rate. The effectiveness factor for $\mathrm{HCl}$ absorption can be estimated to be nearly unity based on the measured pore volume distribution before and after $\mathrm{HCl}$ absorption. Except in the initial stages of reaction, mass transfer rates estimated for the fixed bed reactor indicate $<10 \%$ influence on the measured rates. The rate constant for $\mathrm{HCl}$ removal by nahcolite at $600^{\circ} \mathrm{C}$ in the presence of $\mathrm{H}_{2} \mathrm{~S}$ appears to be about $30 \%$ less than that in the absence of $\mathrm{H}_{2} \mathrm{~S}$. The low rate constant calculated for the run at 150 psig is rather low due to the low porosity of the pellets than due to the elevated gas pressure.

Table 20

HCI ABSORPTION RATE CONSTANTS FOR FIXED-BED REACTOR SORBENTS

\begin{tabular}{lcccc}
$\begin{array}{c}\text { Data Set for } \\
\text { Curve-Fit }\end{array}$ & Sorbent & $\mathbf{T ~}\left({ }^{\circ} \mathbf{C}\right)$ & $\mathbf{S}_{\mathbf{0}}\left(\mathbf{g C l} / \mathbf{g}_{\mathbf{S}}\right)$ & $\begin{array}{c}\mathbf{k}[\mathbf{m o l} \mathbf{C l} \\
\left.\left(\mathbf{a t m} \mathbf{H C l}_{\mathbf{g}} \cdot \mathbf{h}\right)\right]\end{array}$ \\
\hline Solid analysis & L-10 & 400 & 0.58 & 2.6 \\
Gas analysis & L-10 & 400 & - & 5.2 \\
Solid analysis & L-10 & 500 & 0.58 & 4.1 \\
Gas analysis & L-07 & 500 & - & 2.8 \\
Solid analysis & L-07 & 500 & 0.52 & 3.5 \\
Gas analysis & L-08 & 500 & - & 2.9 \\
Solid analysis & L-08 & 500 & 0.52 & 3.2 \\
Solid analysis ${ }^{1}$ & L-26 & 500 & 0.45 & 1.7 \\
Solid analysis & L-10 & 600 & & 2.2 \\
Gas analysis & L-10 & 600 & 0.51 & 3.7 \\
\hline${ }^{1}$ Run at 150 psig; all others at atmospheric pressure. &
\end{tabular}




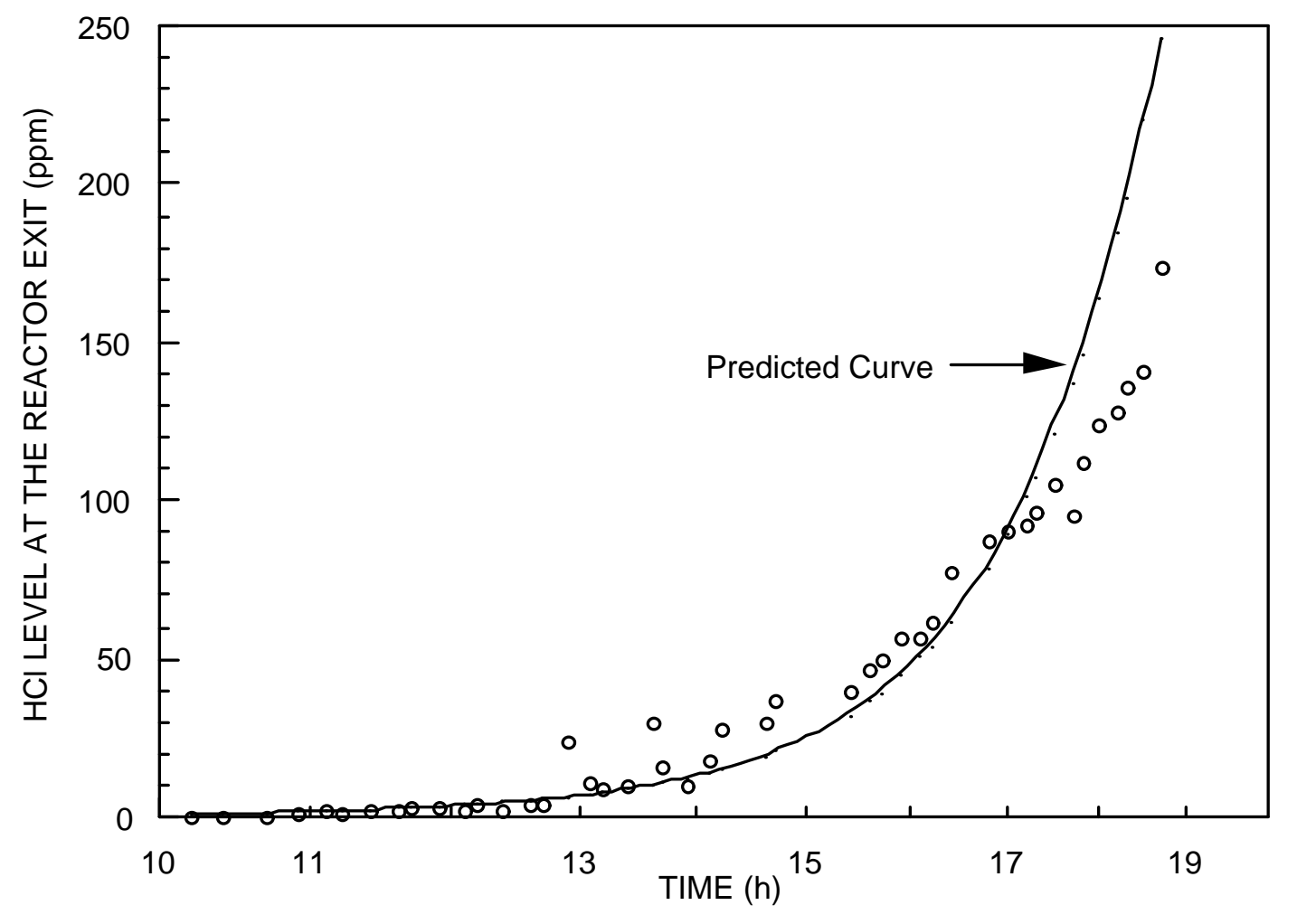

Figure 43. Comparison of actual and predicted $\mathrm{HCl}$ breakthrough curve at $500^{\circ} \mathrm{C}$ for L-07 pellets. 


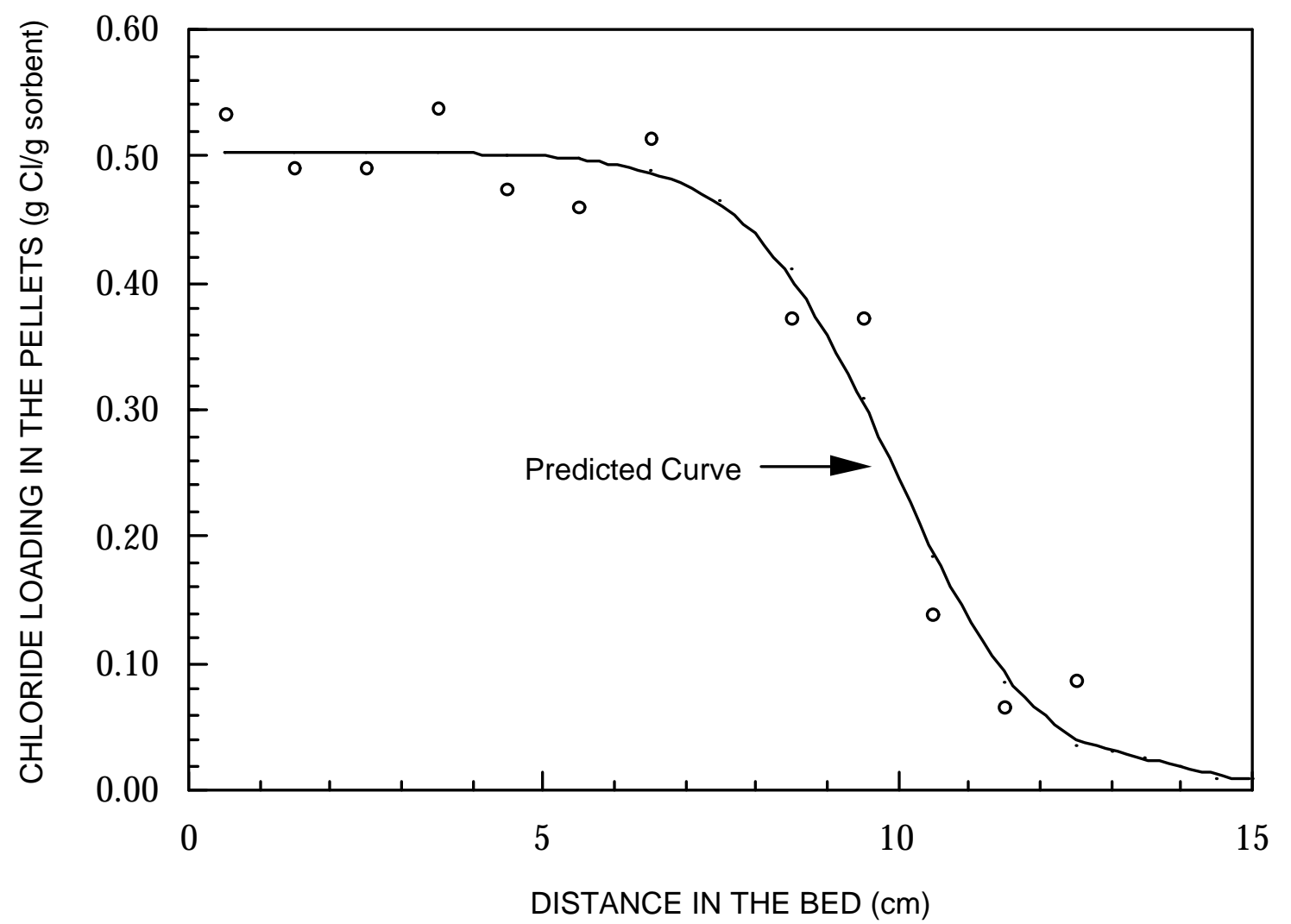

Figure 44. Comparison of actual and predicted chloride loading as a function of bed depth at $500^{\circ} \mathrm{C}$ for L-07 pellets.

\section{FLUIDIZED-AND ENTRAINED-BED DATA}

The data from the atmospheric fluidized-bed reactor were analyzed using a simple mathematical model which was originally developed for coal gas desulfurization using zinc titanate sorbents. This model assumes a plug flow of gas and complete mixing of solids. Chemical analysis of spent sorbent granules from the top, middle, and bottom of the bed showed that the bottom end contained a high level of chloride (54.0 wt $\%$ ), while middle and top sections contained 37.3 and $46.1 \mathrm{wt} \%$ chloride, respectively. Although these results do not validate the assumption of complete solid mixing, they do provide evidence of a significant mixing of solid particles. Note that in a fixed-bed reactor, the upstream end of the bed would have been nearly saturated $(>50$ wt $\%$ chloride) while the downstream end has about $2 \mathrm{wt} \%$ chloride. The global rate constants, evaluated using this model are shown in Table 21. 
Table 21

\section{GLOBAL RATE CONSTANTS FOR FLUIDIZED- AND ENTRAINED-BED REACTORS}

\begin{tabular}{lllc}
\multicolumn{1}{c}{ Sorbent } & Reactor Type & \multicolumn{1}{c}{ Gas Composition } & Rate Constant $^{1}$ \\
\hline N-01 $(90$ to $300 \mu \mathrm{m})$ & Fluidized-bed & $\begin{array}{l}\text { Texaco coal gas with } \\
1750 \mathrm{ppm} \mathrm{HCl}\end{array}$ & 0.9 \\
N-23 $(90$ to $300 \mu \mathrm{m})$ & Fluidized-bed & $\begin{array}{l}\text { Texaco coal gas with } \\
1750 \mathrm{ppm} \mathrm{HCl}\end{array}$ & 1.2 \\
NS-01 $(45$ to $90 \mu \mathrm{m})$ & Fluidized-bed & $\begin{array}{l}\text { Texaco coal gas with } \\
1750 \mathrm{ppm} \mathrm{HCl}\end{array}$ & 3.0 \\
N-01 $(45$ to $90 \mu \mathrm{m})$ & Entrained-bed & $\begin{array}{l}2.1 \% \mathrm{HCl} \text { in } \mathrm{N}_{2} \\
\text { Texaco coal gas with }\end{array}$ & 0.3 \\
N-01 $(45$ to $90 \mu \mathrm{m})$ & Entrained-bed & 0.5 \\
& & $\begin{array}{l}2000 \mathrm{ppm} \mathrm{HCl} \\
\text { Texaco coal gas with } \\
1750 \mathrm{ppm} \mathrm{HCl}\end{array}$ & $4 \pm 1$ \\
L-07 $(3 \mathrm{~mm})$ & Fixed-bed & &
\end{tabular}

${ }^{1}$ Rate constant mole of $\mathrm{Cl} /\left(\mathrm{atm}_{\mathrm{HCl}} \cdot \mathrm{g}_{\mathrm{S}} \cdot \mathrm{h}\right)$

The calculated rate constants were the highest for the fixed-bed reactor, moderate for the fluidized-bed reactor, and smallest for the entrained-bed reactor. The rate constant observed for the spray-dried sorbent for the fluidized-bed reactor approached that found for the fixed-bed reactor. The calculated values are in the same order of magnitude, within the accuracy expected in these calculations. 


\section{PILOT-SCALE TESTING OF SORBENTS}

\section{TESTS AT GE-CRD FACILITY}

GE-CRD conducted a test in May 1995 at its fixed-bed gasifier hot gas cleanup unit using the hot coal gas stream from a fixed-bed gasifier. This test (7B2) was conducted by GE-CRD as part of a separate program, and they agreed to test a batch of NS-02 spray-dried sorbent (100 to $150 \mu \mathrm{m}$ particles) at no additional cost. RTI supplied to GE-CRD $110 \mathrm{lb}$ of spray-dried nahcolite (NS-02) sorbent (prepared by CMP, Inc., using its pilot-scale spray drier) in the 100 to $150 \mu \mathrm{m}$ particle size range.

The $\mathrm{HCl}$ removal unit in the GE-CRD pilot-scale facility was a circulating-fluidized-bed (CFB) reactor downstream of the primary cyclone but ahead of the moving-bed desulfurization unit (Bevan et al., 1995). The sorbent was injected into the reactor pneumatically using a screw feeder to control the rate of feed. Depending on the particle size and gas velocity, the bottom of the CFB acted as a fluidized-bed reactor, while fine particles were entrained in the gas stream at the upper level of the reactor. An internal cyclone recycled the fine sorbent particles to the bottom of the reactor through a dipleg. Clean gas exited from the top of the CFB. Spent sorbent was removed from the overflow of the fluidized-bed section through a lock-hopper.

Three types of sorbents were used in the test. Initially, USP Grade \#5 (coarse granular) was used and then the reactor feed was switched to USP Grade \#2 (fine granular). The results show that when using Grade \#2 sodium bicarbonate the circulating-fluidized-bed reactor was very effective in reducing the $\mathrm{HCl}$ vapor level from hot coal gas streams (Figure 45). Initially, the residual $\mathrm{HCl}$ level was somewhat high due to low sorbent level in the reactor. During this time, the pressure drop across the reactor was also very low, again due to low inventory of the sorbent. As the bed inventory was built up, the $\mathrm{HCl}$ removal efficiency increased. During the last $15 \mathrm{~h}$ of the $100 \mathrm{~h}$ test, the Grade \#2 sodium carbonate was replaced with $110 \mathrm{lbs}$ of spray-dried nahcolite granules supplied by RTI (NS-02). The calculated HCl removal efficiency was greater than $97 \%$ with both sorbents (Figure 46). The spent sorbents contained as much as $35 \mathrm{wt} \%$ chloride corresponding to a sorbent utilization of $55 \%$. 


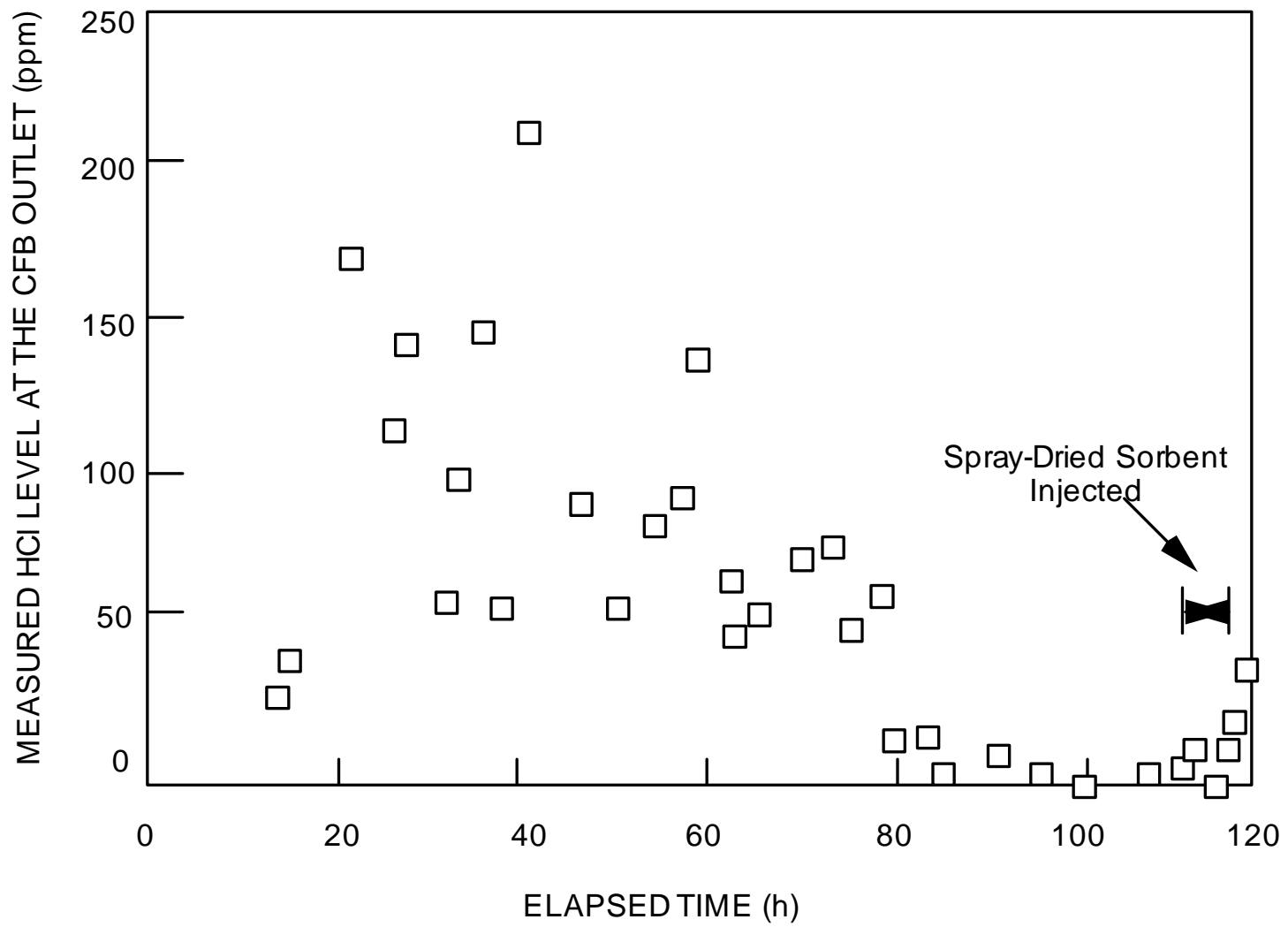

Figure 45. The measured $\mathrm{HCl}$ level during the pilot-scale test at GE-CRD with the spray-dried sorbent. 


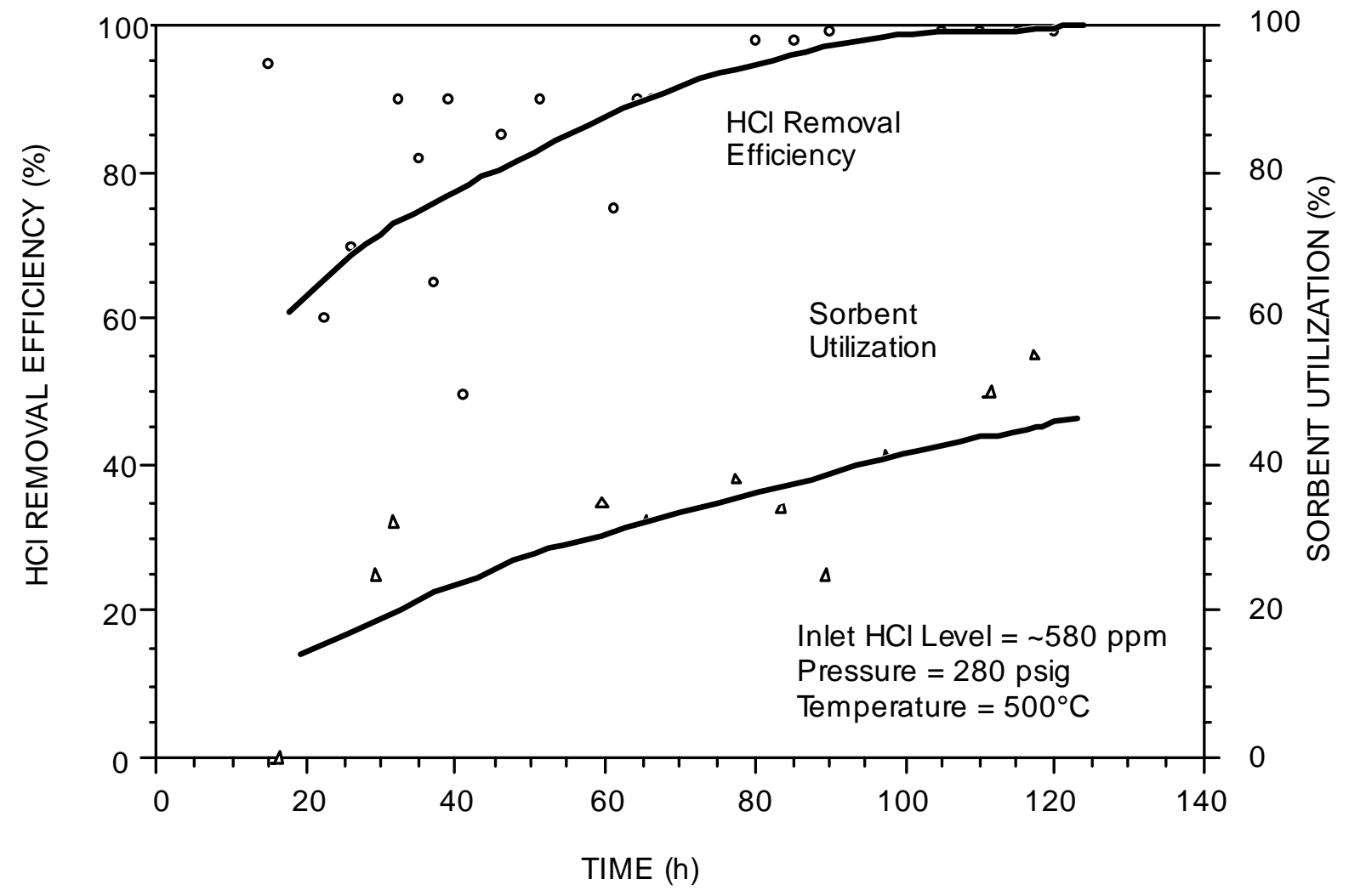

Figure 46. Sorbent utilization and the $\mathrm{HCl}$ removal efficiency during the pilotscale test at GE-CRD. 
The tests at GE-CRD showed that the NS-02 sorbent removed $\mathrm{HCl}$ in the coal gas from 580 ppmv to less than 15 ppmv, which was the detection limit of GE-CRD's analytical equipment. A batch of the spent sorbent, designated as NS2GE, was analyzed by RTI for its chloride and trace metal contents. The reacted sorbent was black in color and it was a mixture of reacted NS-02 $(\mathrm{NaCl})$, unreacted NS-02 $\left(\mathrm{Na}_{2} \mathrm{CO}_{3}\right)$, binder solids, and entrained ash particles that were not removed by the primary cyclone. The analysis of the trace metals in the spent sorbent is described in next section.

The chloride content of the NS2GE sample was found to be $35 \mathrm{wt} \%$, suggesting that its $\mathrm{NaCl}$ content was $57.8 \mathrm{wt} \%$. GE-CRD also analyzed this sorbent independently and found that the chloride content varied between 31 to $35 \mathrm{wt} \%$ confirming RTI's analysis. The actual chloride capacity based on the parent NS-02 sorbent could not be determined because the amount of ash in the NS2GE sample was not known. Determination of the total sodium content of the sample could not provide an estimate of the chloride capacity, because some of the sodium in the reacted sorbent might be due to the presence of ash. Hence, the amounts of water soluble Na compounds and the total $\mathrm{Na}$ in the sample were analyzed. In the first procedure, the sample was dissolved in the hot water and the Na concentration in the solution was analyzed by inductively-coupled plasma (ICP). The hot water dissolution presumably provided the sodium concentration of the sample due to the presence of $\mathrm{Na}_{2} \mathrm{CO}_{3}$ and $\mathrm{NaCl}$ only. In the second procedure, an $\mathrm{HF}$ solution was used to dissolve all sodium compounds in the sample and the solution was analyzed for its sodium concentration.

The sodium content of the sorbent in the NS2GE was found to be $31.7 \mathrm{wt} \%$ on hot water dissolution and $33.5 \mathrm{wt} \%$ on HF-dissolution. Based on material balance calculations, the actual chloride capacity obtained in the CFB was $37.6 \mathrm{wt} \%$, corresponding to a sorbent utilization of $71 \%$. The ash content of the NS2GE material was $1.5 \mathrm{wt} \%$.

GE-CRD also provided to RTI a batch of the spent sorbent from the Grade \#2 sodium bicarbonate feed (NG7B-II). This sorbent was also black indicating the presence of ash. Chloride analysis of NG7B-II indicated that it had $11.5 \mathrm{wt} \%$ capacity.

Based on the above analysis, the NS-02 sorbent performance in the first trial run should be considered excellent because of its high sorbent utilization (71\%) and its ability to reduce the chloride level in the coal gas from 580 ppmv to less than 15 ppmv, the detection of limit of the analytical equipment used.

Based on the encouraging results obtained from this test, additional testing of spray-dried sorbent was arranged. RTI arranged to manufacture $2000 \mathrm{lb}$ of spray-dried nahcolite sorbent and shipped it to GE-CRD in December 1995. Because of a delay in procuring funds for the gasifier 
run by GE-CRD, the sorbent was stored in the pilot-plant facility for 4 months. When the gasifier run was started in April 1996, the sorbent could not be fed successfully into the CFB because of bridging problems in the feed hopper. GE-CRD continued the gasifier run without testing that batch of spray-dried sorbent. No additional gasifier runs were available at GE-CRD to test the spray-dried sorbent for $\mathrm{HCl}$ removal.

\section{SORBENT FLOWABILITY STUDIES}

In the bench- and pilot-scale reactors, the spray-dried sorbent exhibited high reactivity for $\mathrm{HCl}$ vapor in coal gas and high chloride capacities. In test run 7B at the GE-CRD pilot-scale facility, only minor problems were found with flowability of the small batch of spray-dried NS-01 sorbent. During loading of the $110 \mathrm{lb}$ of the NS-02 sorbent into the inlet lockhopper GE-CRD had to use a vibrator to make the material flow through the screw feeder. GE did not have any problems withdrawing the spent material from the CFB.

The use of the vibrator to load the sorbent into the feed hopper indicated a potential flowability problem. To better understand this flowability problem, the angle of repose, $\theta$, of the spray-dried sorbent was measured. Angle of repose is a physical property of a powder that is weakly related to its flow characteristics. The angle of repose is determined by slowly pouring the powder through a funnel with a fixed outlet at a known distance from the bench top. The powder flow is stopped when the apex of the pile formed by the powder just contacts the bottom of the funnel. The angle of repose then is the angle between the horizontal surface and the solid-bed top surface (or the angle of incline of the cone of powder from the horizontal). The more flowable the powder is, generally, the smaller the angle of repose. Powders with an angle of repose greater than $45^{\circ}$ are considered to exhibit poor flowability, whereas those with an angle of repose less than $30^{\circ}$ are expected to flow freely.

The angle of repose of the spray-dried sorbent was measured by GE-CRD using a standard plastic funnel with a $10 \mathrm{~cm}$ opening and $1.6 \mathrm{~cm}$ outlet. The height of the funnel outlet was fixed at $2.5 \mathrm{~cm}$ from the bench top. The angle was calculated as the arc tangent of the height of the pile divided by one half of the width of the pile.

GE-CRD measured the angle of repose of the USP Grade \#2 and \#3 sodium carbonate powder and spray-dried sorbent with two particle size ranges (45 to $90 \mu \mathrm{m}$ and 90 to $150 \mu \mathrm{m}$ ). The angle of repose and the flow characteristics of various nahcolite powders are described in Table 22. These measurements showed that the Grade \# 3 and the NS-01 (45 to $90 \mu \mathrm{m}$ ) sorbents have poor flowability $\left(\theta>45^{\circ}\right)$ and may be classified as nonflowing powder. Both, NS-01 (90 to $150 \mu \mathrm{m})$ and Grade \# 2 sorbents appear to have good flowability, based on $\theta$ measurements. 


\section{Table 22}

\section{ANGLE OF REPOSE OF HCI REMOVAL SORBENTS}

\begin{tabular}{lcl}
\multicolumn{1}{c}{ Sorbent } & Angle of Repose $\left(^{\circ}\right)$ & Flowability \\
\hline Grade \#2 & $27-30$ & Excellent \\
Grade \#3 DF & $45-49$ & Very poor \\
NS-01 (45 to $90 \mathrm{~mm})$ & 46.8 & Very poor \\
NS-01 $(90$ to $150 \mathrm{~mm})$ & 33.8 & Good \\
\hline
\end{tabular}

\section{TESTS AT FETC MGCR FACILITY}

SRI and RTI designed, fabricated, and shipped to FETC at Morgantown two skid-mounted test units suitable for testing fixed- and fluidized-bed reactor tests using a slip stream from the MGCR facility. The slip stream was at a temperature of $\sim 500^{\circ} \mathrm{C}$ and a pressure of $300 \mathrm{psi}$. The key components of the test units were a 11.4-cm ID pressure vessel, a vertical tube furnace, critical flow orifices for controlling the pressure and gas flow, steam condensers, condensate pots, and flow meters. Thermocouples, pressure gauges, and flow meters were used to monitor the process parameters. Both skids were similar in design and construction.

Inside the pressure vessel several sorbent cages were installed, each containing a different type of sorbent (Figure 47). The sorbent cages consisted of 2.5 -cm diameter stainless steel tube fitted with stainless steel frits in the bottom. The temperature of the sorbents bed was controlled by the tube furnace. Two pelletized sorbents $(3$ and $5 \mathrm{~mm}$ ) were used for the fixed-bed reactor tests, while three granular sorbents (two spray-dried and one commercial baking soda) were used for the fluidized-bed reactor tests. 


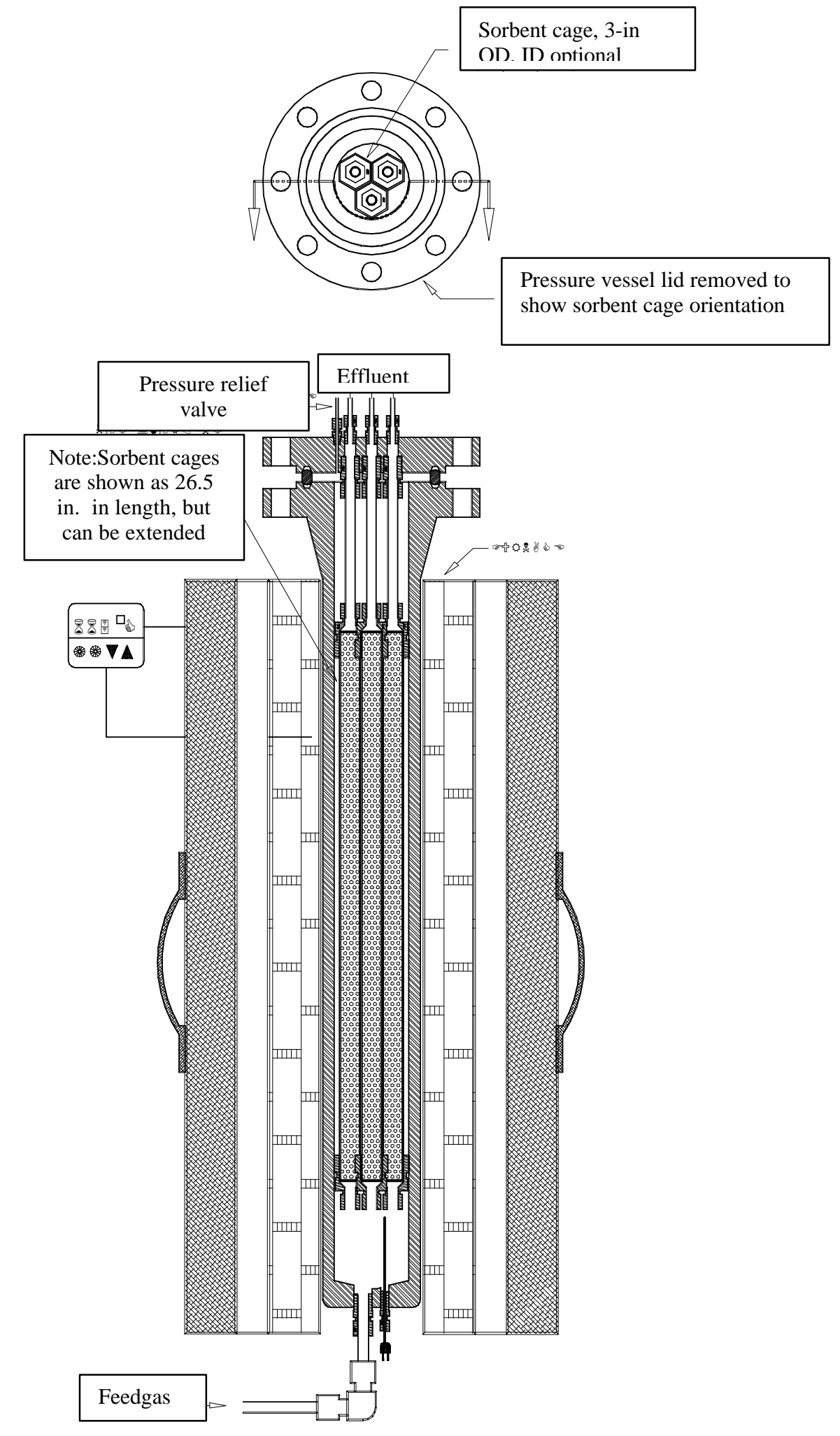

Fig 47. Schematic diagram of the sorbent beds in the skid-mounted system used for hot coal gas exposure tests at DOE-FETC's MGCR unit. 
Figure 48 and 49 are piping and instrumentation diagrams showing the flow paths of the coal gas slip stream. The equipment between the heavy dashed lines was included in the skid. A hot coal gas stream was supplied by the MGCR to the top or bottom of the pressure vessel. The gas stream flowed from the top to bottom in the fixed-bed reactor. This type of arrangement was suitable to determine the chloride and trace metal levels in the sorbent pellets as a function of bed depth. The gas stream flowed from bottom to top in the fluidized-bed reactor, as required for fluidization. The outlet gas stream from each sorbent bed passed separately through a pressure reduction orifice (critical flow orifice), an air-cooled coil to remove heat, a vessel to receive the steam condensate, a rotameter, and a needle valve for fine flow control. The cooled gas streams were connected to a manifold on the skid for discharge to the FETC-Morgantown incinerator. A common condensate pot was provided to transfer the liquid from the individual pots and drain it at a relatively low pressure.

After its construction, the reactor system were tested at SRI and RTI using nitrogen. Following the shakedown testing, the skids were installed at the MGCR facility at FETC, Morgantown.

Following a $100 \mathrm{~h}$ test at $500^{\circ} \mathrm{C}$, the spent sorbents were removed from the cages. The chloride content from the top, middle, and bottom of each sorbent cages. The chloride content of the sorbent pellets in the fixed-bed cages were below the detection limit (Table 23). In the fluidized-bed cages, chloride was detected only at the bottom portion of the bed at a level of about $0.4 \pm 0.1 \mathrm{wt} \%$. These results indicate that the $\mathrm{HCl}$ vapor levels were very low in the coal gas stream. The results of trace metal accumulation on the sorbents are described in the next section.

The main objective of the tests at the MGCR facility was to obtain the accumulation of trace metals on the chloride removal sorbents. Bench-scale tests at SRI, RTI, and GE-CRD have shown that nahcolite-based sorbents have both rapid reaction rates with $\mathrm{HCl}$ vapor in the coal gas stream with high chloride capture capacities, and hence, obtaining data relating to $\mathrm{HCl}$ reactivity and chloride capacity was considered a secondary objective. Because the MGCR was operated with a coal (Montana \#7) containing a very low level of chlorides (97 ppm), the low chloride levels found in the exposed sorbents were not surprising. 


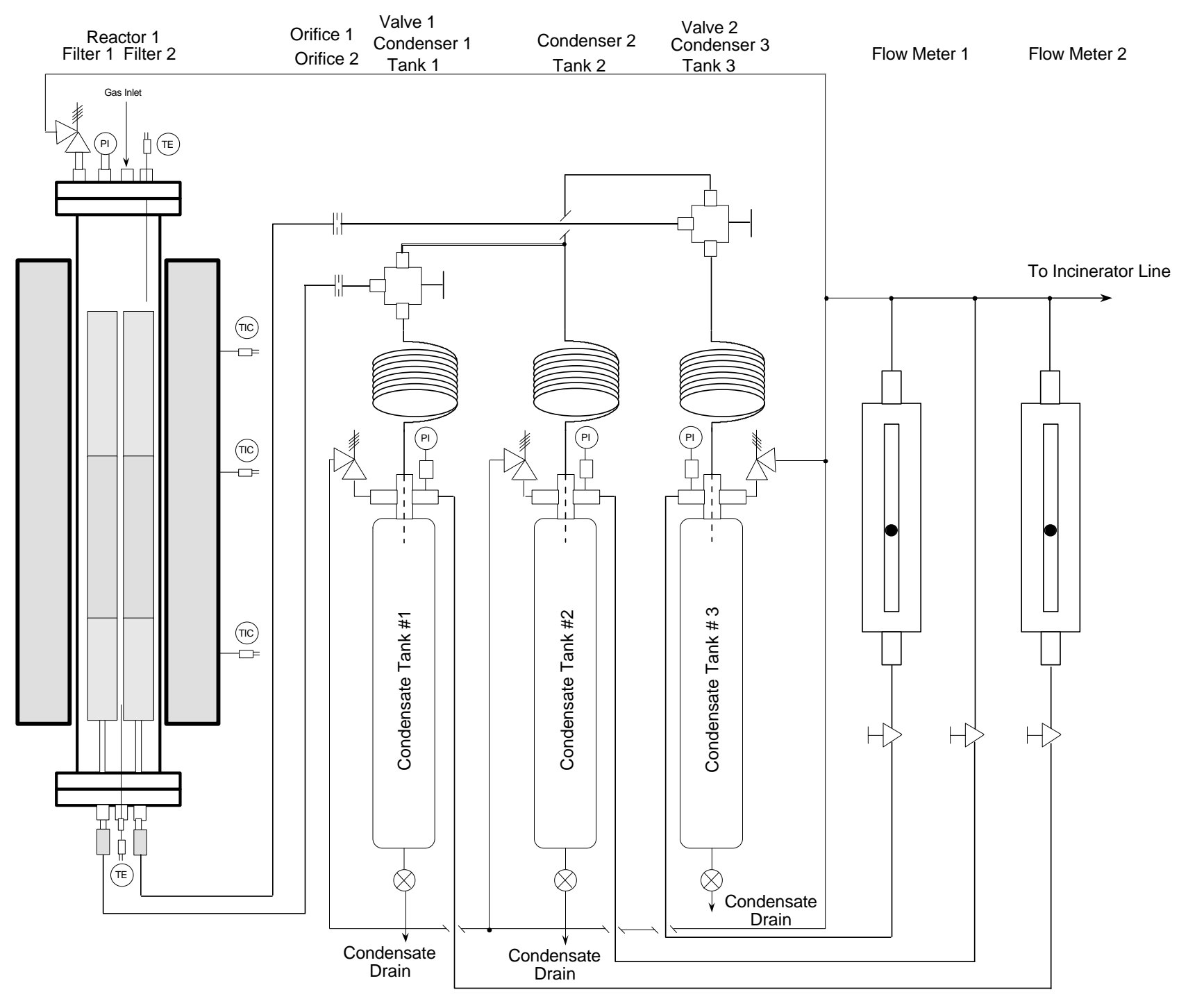

Figure 48. Schematic diagram of the skild-mounted fixed-bed reactor system for hot coal gas exposure tests at DOE-FETC's MGCR unit. 


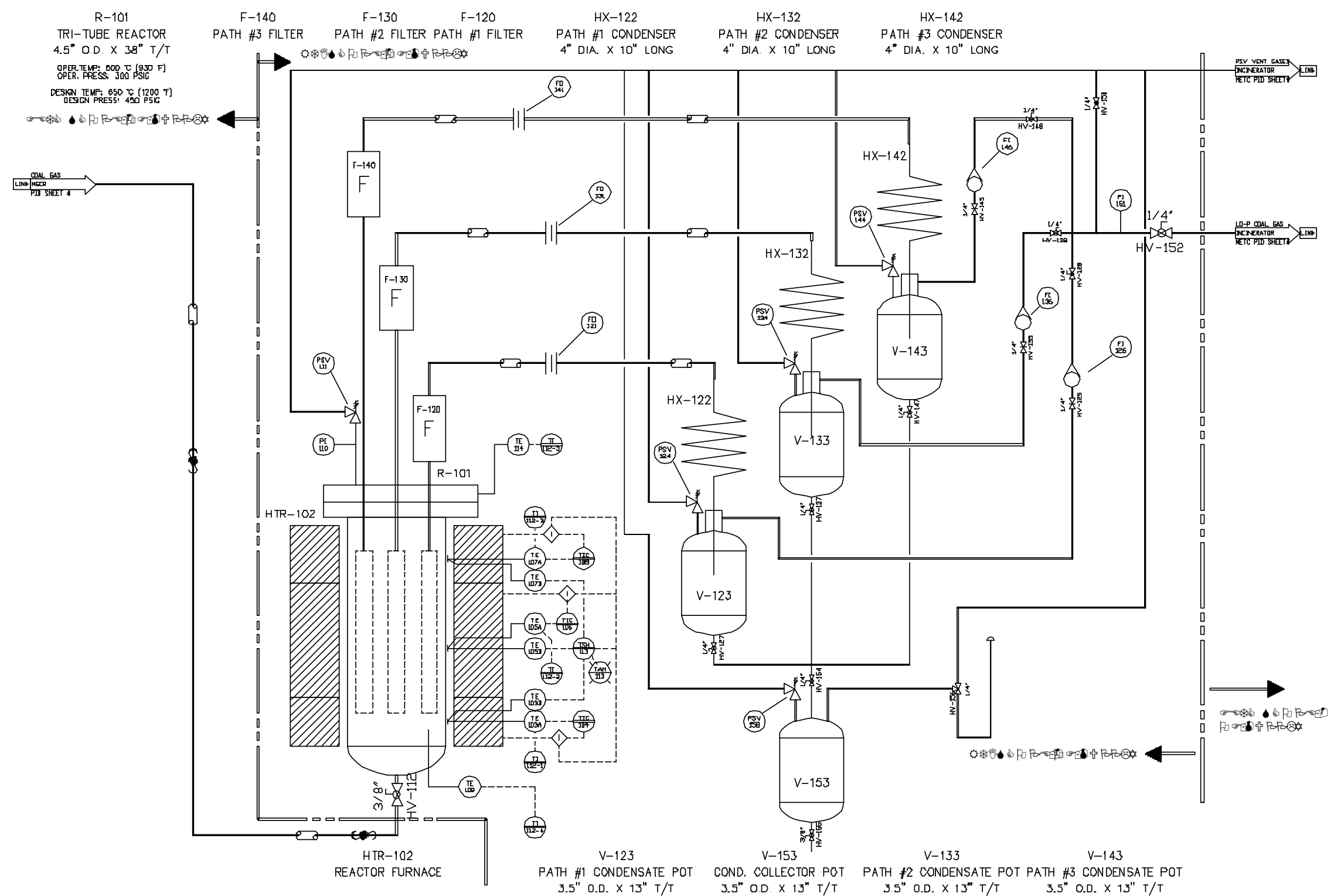

Figure 49: Schematic diagram of the skid-mounted fluidized-bed reactor system used for hot coal gas exposure tests at DOE/FETC's MGCR unit 
Table 23

CHLORIDE CONTENT OF THE SORBENTS EXPOSED TO
HOT COAL GAS AT MGCR FACILITY

\begin{tabular}{lll} 
Reactor Type & Bed Section & Chloride Level (wt\%) \\
\hline Fixed-bed \#1 & Top & N.D \\
Fixed-bed \#1 & Middle & N.D \\
Fixed-bed \#1 & Bottom & N.D \\
Fixed-bed \#1 & Top & N.D \\
Fixed-bed \#1 & Middle & N.D \\
Fixed-bed \#1 & Bottom & N.D \\
Fluidized-bed \#1 & Top & N.D \\
Fluidized-bed \#1 & Middle & N.D \\
Fluidized-bed \#1 & Bottom & 0.44 \\
Fluidized-bed \#2 & Top & N.D \\
Fluidized-bed \#2 & Middle & N.D \\
Fluidized-bed \#2 & Bottom & N.D \\
Fluidized-bed \#3 & Mottom & N.D \\
Fluidized-bed \#3 & & \\
Fluidized-bed \#3 & Mop & \\
\hline
\end{tabular}




\section{SPENT SORBENT ANALYSIS}

The metal content of the NS2GE sample was determined by completely dissolving the sample in HF solution and analyzing the dissolved solution for metals using the ICP spectrometer. The results of this analysis, shown in Table 24, indicate that both the USP-grade (NG7B) and the spray-dried (NS2GE) sorbents have accumulated lead in them. The spray-dried sorbent accumulated more boron than the USP grade sorbent. The differences in the level of boron between both these sorbents may be due to the amount of ash present in them. Based on the sodium analysis, we calculated that the NS2GE sorbent contained $1.5 \mathrm{wt} \%$ ash whereas the NG7B contained very little ash.

The trace metal analysis of the sorbents exposed to MGCR gas stream is shown in Table 25. These results showed no significant accumulation of trace metals in the sorbent. Lead levels in the exposed sorbents were very low. Based on these results, the expected level of accumulation of trace metals in the spent sorbent is not certain. At the GE-CRD facility, the sorbents were exposed to hot coal gas without cooling, as the CFB reactor was situated just downstream of the primary cyclone. However, there were no barrier filters to keep some of the coal ash from mixing with the sorbent. Hence, the distribution of trace metals between the sorbent component and the ash componets could not be verified.

In the MGCR reactor, the sorbents were situated rather far from the gasifier and downstream of a barrier filter and a desulfurization unit. The gas piping was heat traced to keep it hot, but there could be places where trace metal vapor could have condensed out. 


\section{Table 24}

TRACE METAL LEVELS IN THE SORBENTS EXPOSED AT THE GE-CRD FACILITY

\section{Concentration of Trace Metals in the Sorbent (ppm)}

\begin{tabular}{lrrrr}
\cline { 2 - 5 } Element & Spent NS2GE & Fresh NS2GE & Spent NG7B-II & Fresh NG7B-II \\
\hline $\mathrm{Al}$ & 30,900 & 36,100 & $<350$ & 213 \\
$\mathrm{~B}$ & 1425 & $<15$ & $<15$ & $<15$ \\
$\mathrm{Ba}$ & 42.5 & 41 & $<9$ & 8 \\
$\mathrm{Be}$ & $<1$ & $<1$ & $<1$ & $<1$ \\
$\mathrm{Cd}$ & 5 & $<3$ & $<3$ & $<1$ \\
$\mathrm{Ca}$ & 714 & 729 & 228 & $<9$ \\
$\mathrm{Cr}$ & $<10$ & 14 & 3.5 & 10.3 \\
$\mathrm{Cu}$ & 22.1 & $<9$ & 205 & 37.2 \\
$\mathrm{Fe}$ & 2660 & 2,785 & 157 & $<15$ \\
$\mathrm{~Pb}$ & 1065 & $<15$ & 45 & 26.8 \\
$\mathrm{Mg}$ & 1075 & 1170 & $<9$ & $<9$ \\
$\mathrm{Mn}$ & 11 & $<9$ & $<15$ & $<15$ \\
$\mathrm{Mo}$ & $<40$ & $<15$ & 176 & $<10$ \\
$\mathrm{Ni}$ & $<15$ & 12 & $<15$ & $<9$ \\
$\mathrm{Sr}$ & 32 & 31 & 8 & $<9$ \\
$\mathrm{~V}$ & 35 & 29 & 27.5 & 48.2 \\
$\mathrm{Zn}$ & 146 & 66 & & \\
& & & & $<$ \\
\hline
\end{tabular}


Table 25

TRACE METAL ANALYSIS OF SPENT SORBENTS EXPOSED

AT THE MGCR FACILITY

\begin{tabular}{|c|c|c|c|c|c|c|c|c|c|c|}
\hline $\begin{array}{c}\text { Sample } \\
\text { Analysis Method }\end{array}$ & $\begin{array}{c}\text { Al } \\
\text { ICP-AES }\end{array}$ & $\begin{array}{c}\text { As } \\
\text { GFAA }\end{array}$ & $\begin{array}{c}\mathbf{B a} \\
\text { ICP-AES }\end{array}$ & $\begin{array}{c}\text { Be } \\
\text { ICP-AES }\end{array}$ & $\begin{array}{c}\mathbf{B i} \\
\text { ICP-MS }\end{array}$ & $\begin{array}{c}\text { Cd } \\
\text { ICP-AES }\end{array}$ & $\begin{array}{c}\mathbf{C r} \\
\text { ICP-AES }\end{array}$ & $\begin{array}{c}\mathbf{C u} \\
\text { ICP-AES }\end{array}$ & $\begin{array}{c}\mathbf{F e} \\
\text { ICP-AES }\end{array}$ & $\begin{array}{c}\text { Hg } \\
\text { CVAA }\end{array}$ \\
\hline \multicolumn{11}{|c|}{ Samples from the SRI Fixed-bed Reactor \#1 } \\
\hline Top (Gas Inlet) & 10,120 & 1.05 & 21.45 & 0.18 & 0.041 & 0.14 & 10.6 & 1.75 & 3520 & $<0.1$ \\
\hline Middle & 10,880 & 1.06 & 23.1 & 0.18 & 0.049 & 0.11 & 6.1 & 1.67 & 3636 & $<0.1$ \\
\hline Bottom (Gas Outlet) & 10,900 & 0.97 & 22.88 & 0.18 & $<0.04$ & 0.18 & 5.96 & 1.85 & 3621 & $<0.1$ \\
\hline \multicolumn{11}{|c|}{ Samples from the SRI Fixed-bed Reactor \#2 } \\
\hline Top (Gas Inlet) & 10,720 & $<0.5$ & 21.91 & 0.19 & $<0.04$ & 0.13 & 6.35 & 1.17 & 3638 & $<0.1$ \\
\hline Middle & 11,400 & 0.52 & 23.24 & 0.19 & $<0.04$ & 0.1 & 9.15 & 1.54 & 3751 & $<0.1$ \\
\hline Bottom (Gas Outlet) & 11,660 & 0.62 & 23.15 & 0.19 & $<0.04$ & 0.1 & 6.17 & 1.42 & 3778 & $<0.1$ \\
\hline \multicolumn{11}{|c|}{ Samples from the RTI Fluidized-bed Reactor \#1 (Sample Used : NS-02; 90 to $300 \mu \mathrm{m}$ ) } \\
\hline Bottom (Gas Inlet) & 38,460 & 0.87 & 31.22 & 0.23 & 0.093 & 0.24 & 12.4 & 5.57 & 3296 & $<0.1$ \\
\hline Middle & 41,720 & 0.97 & 32.57 & 0.23 & 0.094 & 0.28 & 8.9 & 5.77 & 3680 & $<0.1$ \\
\hline Top (gas Outlet) & 46,110 & 1.42 & 36.19 & 0.24 & $<0.04$ & 0.24 & 43.76 & 8.18 & 4286 & $<0.1$ \\
\hline \multicolumn{11}{|c|}{ Samples from the RTI Fluidized-bed Reactor \#2 (Sample Used : NG-01; >90 $\mu \mathrm{m}$ ) } \\
\hline Bottom (Gas Inlet) & 8.54 & $<0.5$ & 1.16 & $<0.05$ & $<0.04$ & $<0.05$ & 4.49 & 2.34 & 103 & $<0.1$ \\
\hline Middle & 7.32 & $<0.5$ & 1.13 & $<0.05$ & $<0.04$ & $<0.05$ & 1.9 & 1.48 & 83 & $<0.1$ \\
\hline Top (gas Outlet) & 11.88 & $<0.5$ & 1.12 & $<0.05$ & $<0.04$ & $<0.05$ & 1.99 & 1.98 & 161 & $<0.1$ \\
\hline \multicolumn{11}{|c|}{ Samples from the RTI Fluidized-bed Reactor \#3 (Sample Used : NS-02-01; >75 $\mu \mathrm{m}$ ) } \\
\hline Bottom (Gas Inlet) & 26,770 & 0.67 & 30.52 & 0.19 & 0.151 & 0.2 & 13.36 & 4.01 & 2431 & $<0.1$ \\
\hline Middle & 39,450 & 1.5 & 41.33 & 0.28 & 0.144 & 0.19 & 15.32 & 5.61 & 3412 & $<0.1$ \\
\hline Top (gas Outlet) & 39,940 & 0.79 & 42.14 & 0.29 & 0.146 & 0.23 & 18.8 & 8.83 & 3959 & $<0.1$ \\
\hline \multicolumn{11}{|c|}{ Samples from the FETC's MGCR Fluidized-bed Reactor (EX-S03 zinc titanate sorbent) } \\
\hline EX-S03CC (Reacted) & 11,520 & $<0.5$ & 44.25 & $<0.05$ & & 5.2 & 6.46 & 13.35 & 4070 & $<0.1$ \\
\hline
\end{tabular}


Table 25 (continued)

TRACE METAL ANALYSIS OF SPENT SORBENTS EXPOSED AT THE MGCR FACILITY

\begin{tabular}{|c|c|c|c|c|c|c|c|c|c|c|}
\hline $\begin{array}{c}\text { Sample } \\
\text { Analysis Method }\end{array}$ & $\begin{array}{c}\mathbf{M g} \\
\text { ICP-AES }\end{array}$ & $\begin{array}{c}\text { Mn } \\
\text { ICP-AES }\end{array}$ & $\begin{array}{c}\text { Mo } \\
\text { ICP-AES }\end{array}$ & $\begin{array}{c}\mathbf{N i} \\
\text { ICP-AES }\end{array}$ & $\begin{array}{c}\text { Sb } \\
\text { ICP-MS }\end{array}$ & $\begin{array}{c}\mathbf{P b} \\
\text { ICP-AES }\end{array}$ & $\begin{array}{c}\text { Se } \\
\text { GFAA }\end{array}$ & $\begin{array}{c}\mathrm{Sr} \\
\text { ICP-AES }\end{array}$ & $\begin{array}{c}\mathbf{v} \\
\text { ICP-AES }\end{array}$ & $\begin{array}{c}\mathbf{Z n} \\
\text { ICP-AES }\end{array}$ \\
\hline
\end{tabular}

Samples from the SRI Fixed-bed Reactor \#1

$\begin{array}{lll}\text { Top (Gas Inlet) } & 1827 & 9.5 \\ \text { Middle } & 1879 & 9.7\end{array}$

Middle

$1883 \quad 9.7$

$\begin{array}{llr}1.1 & 7.3 & 0.05 \\ 1.7 & 6.1 & 0.055\end{array}$

0.055
0.08

$<1$
1.7
$<1$

$$
<0.5
$$

$<0.5$

33.98

36.35

1.73

1.76

8.96

Samples from the SRI Fixed-bed Reactor \#2

Top (Gas Inlet)

$\begin{array}{lr}1929 & 9.5 \\ 1954 & 10\end{array}$

1954

1.1

5.2

Middle

1988

10

1.1
0.089
$<0.04$
0.045

$<1$
$<1$
$<1$

$<0.5 \quad 34.83$

$<0.5$

36.61

36.1

1.54

1.78

1.65

9.41

Samples from the RTI Fluidized-bed Reactor \#1 ( NS-02; 90 to $300 \mu \mathrm{m}$ )

$\begin{array}{llccc}\text { Bottom (Gas Inlet) } & 1014 & 9.6 & 3.3 & 34.9\end{array}$

$\begin{array}{llrr}1188 & 9.1 & 1.7 & 38\end{array}$

\subsection{7}

0.05

$<1$

(1)

$30.4 \quad 103.7$

$<0.04$

$<1$

$<0.5$

$<0.5$

30.41

30.83

9.28

13.11

16.47

Top (gas Outlet)

zed-bed Reactor \#2 ( NG-01; >90 $\mu \mathrm{m}$ )

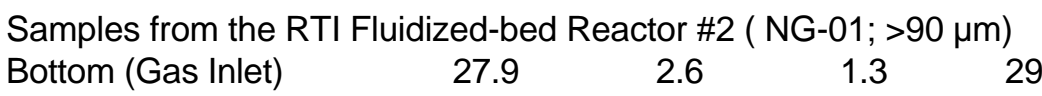

27.9

1.2

$0.8 \quad 26.2$

Top (gas Outlet)

26.1

$1.1 \quad 76.2$

$<0.04$

$<0.04$

$<0.04$

$<0.04$

$<1$

$<0.5$

32.87

78.21

Samples from the RTI Fluidized-bed Reactor \#3 ( NS-02-01; >75 $\mu \mathrm{m}$ )

Bottom (Gas Inlet)

866

1212

6
8.5

$\begin{array}{rr}02-01 ;>75 \mu \mathrm{m}) \\ 1.4 & 14.9\end{array}$

$<0.04$

Middle

1264

14.4

1.921 .3

$<0.04$

$<0.04$

$<0.04$

$<1$

$<0.5$

0.29

0.23

$<0.4$

$<0.4$

37.73

$<1$

$<0.5$

0.26

$<0.4$

44.48

Top (gas Outlet)

$\begin{array}{lcccc}\text { Samples from the FETC's MGCR Fluidized-bed Reactor } & \text { (EX-S03 zinc titanate sorbent) } \\ \text { EX-S03CC (Reacted) } & 494.7 & 8.1 & 7.3 & 44.5\end{array}$

1 Trace metal levels are shown in ppm. $8.1 \quad 7.3 \quad 44.5$

$\begin{array}{lllll}3.6 & <0.5 & 25.58 & 12.73 & 58.63 \\ 4.9 & <0.5 & 34.52 & 17.93 & 57.29 \\ <1 & <0.5 & 36.08 & 18.27 & 115.2\end{array}$


Table 25 (continued)

TRACE METAL ANALYSIS OF SPENT SORBENTS EXPOSED AT THE MGCR FACILITY ${ }^{1}$

$\underline{\text { Steam } \text { Condensate }}{ }^{2}$

\begin{tabular}{lccccccrrrr}
$\begin{array}{c}\text { Sample } \\
\text { Analysis Method }\end{array}$ & $\begin{array}{c}\text { Al } \\
\text { ICP-AES }\end{array}$ & $\begin{array}{c}\text { As } \\
\text { GFAA }\end{array}$ & $\begin{array}{c}\text { BCP } \\
\text { ICP-AES }\end{array}$ & $\begin{array}{c}\text { Be } \\
\text { ICP-AES }\end{array}$ & $\begin{array}{c}\text { Bi } \\
\text { ICP-MS }\end{array}$ & $\begin{array}{c}\text { Cd } \\
\text { ICP-AES }\end{array}$ & $\begin{array}{c}\text { Cr } \\
\text { ICP-AES }\end{array}$ & $\begin{array}{c}\text { Cu } \\
\text { ICP-AES }\end{array}$ & $\begin{array}{c}\text { Fe } \\
\text { ICP-AES }\end{array}$ & $\begin{array}{c}\text { Hg } \\
\text { CVAA }\end{array}$ \\
\hline A LQ-04 & 0.0389 & $<0.006$ & $<0.001$ & $<0.001$ & $<0.00004$ & $<0.001$ & 0.0672 & $<0.006$ & 0.08 & 0.013 \\
B LQ-04 & 0.0352 & $<0.006$ & $<0.001$ & $<0.001$ & $<0.00004$ & $<0.001$ & 0.0634 & $<0.006$ & 0.059 & 0.008 \\
A LQ-05 & 0.0271 & $<0.006$ & $<0.001$ & $<0.001$ & $<0.00004$ & $<0.001$ & 0.0406 & 0.0082 & 0.066 & 0.017 \\
B LQ-05 & 0.0264 & $<0.006$ & $<0.001$ & $<0.001$ & $<0.00004$ & $<0.001$ & 0.0449 & 0.0084 & 0.073 & $<0.002$
\end{tabular}

\begin{tabular}{lrrrrrrrrrr}
$\begin{array}{c}\text { Sample } \\
\text { Analysis Method }\end{array}$ & $\begin{array}{c}\text { Mg } \\
\text { ICP-AES }\end{array}$ & $\begin{array}{c}\text { Mn } \\
\text { ICP-AES }\end{array}$ & $\begin{array}{c}\text { Mo } \\
\text { ICP-AES }\end{array}$ & $\begin{array}{c}\text { Ni } \\
\text { ICP-AES }\end{array}$ & $\begin{array}{c}\text { Sb } \\
\text { ICP-MS }\end{array}$ & $\begin{array}{c}\text { Pb } \\
\text { ICP-AES }\end{array}$ & $\begin{array}{c}\text { Se } \\
\text { GFAA }\end{array}$ & $\begin{array}{c}\text { Sr } \\
\text { ICP-AES }\end{array}$ & $\begin{array}{c}\mathbf{V} \text { ICP-AES } \\
\text { ICP-AES }\end{array}$ \\
\hline A LQ-04 & 0.031 & 0.206 & $<0.004$ & 0.03 & $<0.00004$ & $<0.011$ & 0.04 & $<0.002$ & $<0.004$ & $<0.011$ \\
B LQ-04 & $<0.022$ & 0.028 & $<0.004$ & 0.019 & $<0.00004$ & $<0.011$ & 0.088 & $<0.002$ & $<0.004$ & $<0.011$ \\
A LQ-05 & $<0.022$ & 0.007 & $<0.004$ & 0.022 & $<0.00004$ & $<0.011$ & 0.002 & $<0.002$ & $<0.004$ & $<0.011$ \\
B LQ-05 & 0.031 & 0.018 & $<0.004$ & 0.01 & $<0.00004$ & $<0.011$ & 0.077 & $<0.002$ & $<0.004$ & $<0.011$
\end{tabular}

Samples on Heavy Metals Sequestering from GE-CRD Pilot-Plant Run

\begin{tabular}{|c|c|c|c|c|c|c|c|c|c|}
\hline Fresh NS-02 & 1130 & $<9$ & $<15$ & 12.3 & $<15$ & NM & 27.7 & 27.5 & 76.1 \\
\hline Reacted NS-02 & 1080 & 11.7 & 50.4 & $<15$ & 1080 & NM & 30.8 & 18.9 & 180 \\
\hline Fresh NG-01 & 30.1 & $<9$ & $<15$ & $<10$ & $<15$ & NM & $<9$ & $<9$ & 78 \\
\hline Reacted NG-01 & 50.4 & $<9$ & $<15$ & 18.3 & 172 & NM & $<15$ & 7.2 & 30 \\
\hline
\end{tabular}

1 Concentrations are in ppm.

2 The condensate was the effluent of RTI's fluidized-bed reactor

Legend

NM : Not Measured

ICP-AES : Inductively Coupled Plasma- Atomic Emission Spectrometry:

GFAA : Graphite Furnace Atomic Absorption Spectrometry

CVAA : Cold Vapor Atomic Absorption Spectrometry

ICP-MS: Inductively Coupled Plasma- Mass Spectrometry 


\section{PRELIMINARY ECONOMIC ASSESSMENT}

The objective of this task was to provide a preliminary technical and economic evaluation of the process for high-temperature removal of $\mathrm{HCl}$ vapor from coal gases. The evaluation is based on an earlier assessment prepared for $\mathrm{HCl}$ removal from coal gas streams (Krishnan et al., 1986). In that assessment, only a fixed-bed reactor configuration was considered. Based on the results of the current work and pilot-scale testing at GE-CRD, a circulating-fluidized-bed configuration in the present assessment is included.

\section{CONCEPTUAL SYSTEM CONFIGURATIONS}

The complete high temperature cleanup system will consist of the necessary heat recovery section for the gasifier product gases, a particulate removal system, a sulfur removal system, and the hydrogen chloride removal section. The technology for sulfur removal has been advanced significantly in the last decade. Several reactor configurations have been tested at the pilot-scale level using hot gas desulfurization sorbents. A transport reactor configuration was tested by M. W. Kellogg Company (Moorehead et al., 1996) and was installled at the Sierra Pacific Power Company (SPPCo) Piñon Pine Power plant (Demuth and Smith, 1998). GE Environmental Services, in conjunction with GE-CRD, tested several hot gas desulfurization sorbents for movingbed reactor applications in their fixed-bed gasifier facility. A demonstration-scale reactor was to be installed and tested at the Tampa Electric Company's (TECo) Polk Power Station I (Ayala et al., 1997). However, only the economics of high temperature chloride removal step will be considered here.

As stated earlier, regeneration of chloride-laden sorbents is technically complex (the chloride first must be converted to sulfate and then treated with $\mathrm{H}_{2}$ and $\mathrm{CO}_{2}$ to form carbonate) and the spent sorbent must be discarded. Because there is no need to regenerate the sorbent, chloride sorbent system placement is not as critical as for a regenerable system, in which the regeneration off-gas may materially afect the operation of other cleanup units. The only significant issue in the integration of the chloride removal unit is its placement in relation to the sulfur sorbents, whether the chloride system is placed before or after sulfur removal. Difficulties have been encountered with zinc titanate sorbents exposed to $\mathrm{HCl}$ vapor (Gal et al., 1992). The $\mathrm{HCl}$ vapor reacted with the sorbent by forming zinc chlorides. During regeneration, zinc chloride evaporated or reacted with $\mathrm{SO}_{2}$ in the regeneration recycle gas to form zinc sulfate. Deposits of zinc chloride and zinc sulfate were found in the recycle loop heat exchangers and caused eventual 
blockage of the heat exchangers. Hence, it is preferable to place the $\mathrm{HCl}$ removal unit upstream of the desulfurization unit.

\section{CHLORIDE SORBENT SELECTION}

Many sorbents have been tested for removal of $\mathrm{HCl}$ from coal gas streams. They include commercial sorbents and natural minerals. A commercial sorbent, Katalco Chloride Guard, was an efficient $\mathrm{HCl}$ vapor scavenger, but it has low chloride capacity, approximately 4 to $5 \mathrm{wt} \%$. In addition, the cost of commercial quantities of Katalco Guard, about \$4,000/st (short ton), makes it prohibitively expensive to consider its use as a throwaway sorbent. At a 5\% sorbent capacity level, the cost of Katalco Chloride Guard sorbent would be about \$225/st of feed coal. The other commerical sorbent, UCI C-125, also has about $5 \mathrm{wt} \%$ chloride capacity, and it is also prone to formation of zinc chlorides due to the presence of $\mathrm{ZnO}$ in the sorbent.

Although nahcolite was shown to the sorbent of choice based on experimental tests, the economics of using other mineral were considered. In the case of shortite, although there is a potential for separating the mineral from natural deposits in commercial quantities at costs similar to those of other sodium carbonate minerals, its low carrying capacity for chloride makes it a much more expensive option than nahcolite. Shortite is a byproduct of soda ash production from trona ore and no major commercial use for shortite exists currently. At an estimated cost of $\$ 150 /$ st of shortite, the cost of sorbent would be about \$9/st of feed coal (Krishnan et al., 1986). Dawsonite is also not commerially produced currently. Commercial cost of synthetic dawsonite, over $\$ 4000 /$ st, makes it too expensive to consider as a throwaway sorbent, despite its relatively high chloride capture capacity. At a useful capacity of $25 \%$, the cost of dawsonite would be about $\$ 45 /$ st of coal feed.

Nahcolite's high carrying capacity for chloride and low mining costs make it the clear choice of the several sorbents studied. At current estimated prices ( $\$ 150$ to $\$ 225 / \mathrm{st}$ ) of nahcolite sorbent, and an expected chloride loading of $50 \mathrm{wt} \%$, the sorbent cost would be about $\$ 0.85$ to $\$ 1.25 /$ st coal feed to the gasifier. In view of these cost and performance characteristics, nahcolite was the only sorbent considered for the detailed cost estimates.

Commercial production of nahcolite in United States has been sporadic. In the 1980s, solution mining of nahcolite was performed by Cliffs Engineering, Rifle, CO, but its operation has been discontinued. The chemical equivalent of nahcolite is baking soda $\left(\mathrm{NaHCO}_{3}\right)$ and it is commercially produced in United States in large quantitites, about 500,000 tons annually. Commercial, food-grade baking soda was used by GE-CRD for its pilot plant operation and was also used by RTI for preparing spray-dried sorbent for pilot-scale testing. As reported in the 
Chemical Marketing Reporter (October 16, 1995), the cost of commercially available sodium bicarbonate in truck-load quantities is about $\$ 440 /$ ton. The current cost of solution-mined nahcolite is estimated to be about $\$ 225 /$ ton.

\section{ECONOMIC ESTIMATES}

Factored economic estimates were made for the high-temperature chloride removal unit process for a $400 \mathrm{MW}_{\mathrm{e}}$ plant. These estimates are based on preliminary designs developed using results from the bench- and pilot-scale studies.

\section{Process Design Bases and Process Description}

The selected gasifier was the entrained-bed slagging-gasifier (Texaco type) operating under oxygen-blown mode using Illinois No. 6 coal. The gas composition is shown in Table 26, based on a recent analysis of the Texaco gasifier IGCC systems (FETC, 1998). The coal gas from the gasifier is cooled using radiant syngas and convective syngas coolers and pass through a high temperature gas filters before entering the hot gas cleanup section (HGCU). In the $\mathrm{HGCU}, \mathrm{HCl}$ will be removed using a chloride guard bed and $\mathrm{H}_{2} \mathrm{~S}$ will be removed using zinc titanate bed in a $\mathrm{CFB}$ reactor. The mass flow rate to the chloride removal unit will be about $578,105 \mathrm{lb} / \mathrm{h}$ at $535^{\circ} \mathrm{C}$ at a pressure of 385 psia. Two reactor configurations were considered: fixed-bed and circulatingbed. The $\mathrm{HCl}$ vapor content of the gas stream entering the chloride guard was assumed to be $300 \mathrm{ppm}$, although the actual level would depend on the type of coal being used.

Fixed-Bed Reactor Configuration: The commercial-scale chloride removal system will consist of three beds (Figure 50). One of the beds will be out of service at any one time, being reloaded with fresh sorbent. In addition, a blower and two heat exchangers are provided for the nitrogen loop to cool the spent beds during the reloading cycle.

Use of a moving bed reactor was also briefly considered. Such a reactor, in principle, could consist of only one unit in contrast to multiple units necessary for cyclic operation.

However, under pressurized conditions, lock-hoppers are essential for loading and unloading of the sorbent. In addition, calculations indicate that the movement of calcined nahcolite sorbent bed is about 30 to $60 \mathrm{~cm} /$ day ( 1 to $2 \mathrm{ft} /$ day) because of the high chloride capacity of the sorbent. Under these conditions it was not apparent that the additional capital costs of lock-hopper arrangement would offset the cost of additional reactors. Hence, the use of cyclic, multiple reactor units was only considered. 
Table 26

COMPOSITION OF GAS STREAM THROUGH CHLORIDE REMOVAL UNIT

\begin{tabular}{lc} 
Component & Mole\% \\
\hline $\mathrm{H}_{2}$ & 30.7 \\
$\mathrm{CO}$ & 41.6 \\
$\mathrm{CO}_{2}$ & 10.1 \\
$\mathrm{H}_{2} \mathrm{O}$ & 15.2 \\
$\mathrm{~N}_{2}$ & 0.8 \\
$\mathrm{CH}_{4}$ & 0.1 \\
$\mathrm{Ar}$ & 0.8 \\
$\mathrm{HCl}$ & $300 \mathrm{ppm}^{1}$ \\
$\mathrm{H}_{2} \mathrm{~S}$ & 0.7 \\
$\mathrm{Total}$ & 100.0 \\
& \\
\hline
\end{tabular}

1 Assumed value for the economic analysis. 


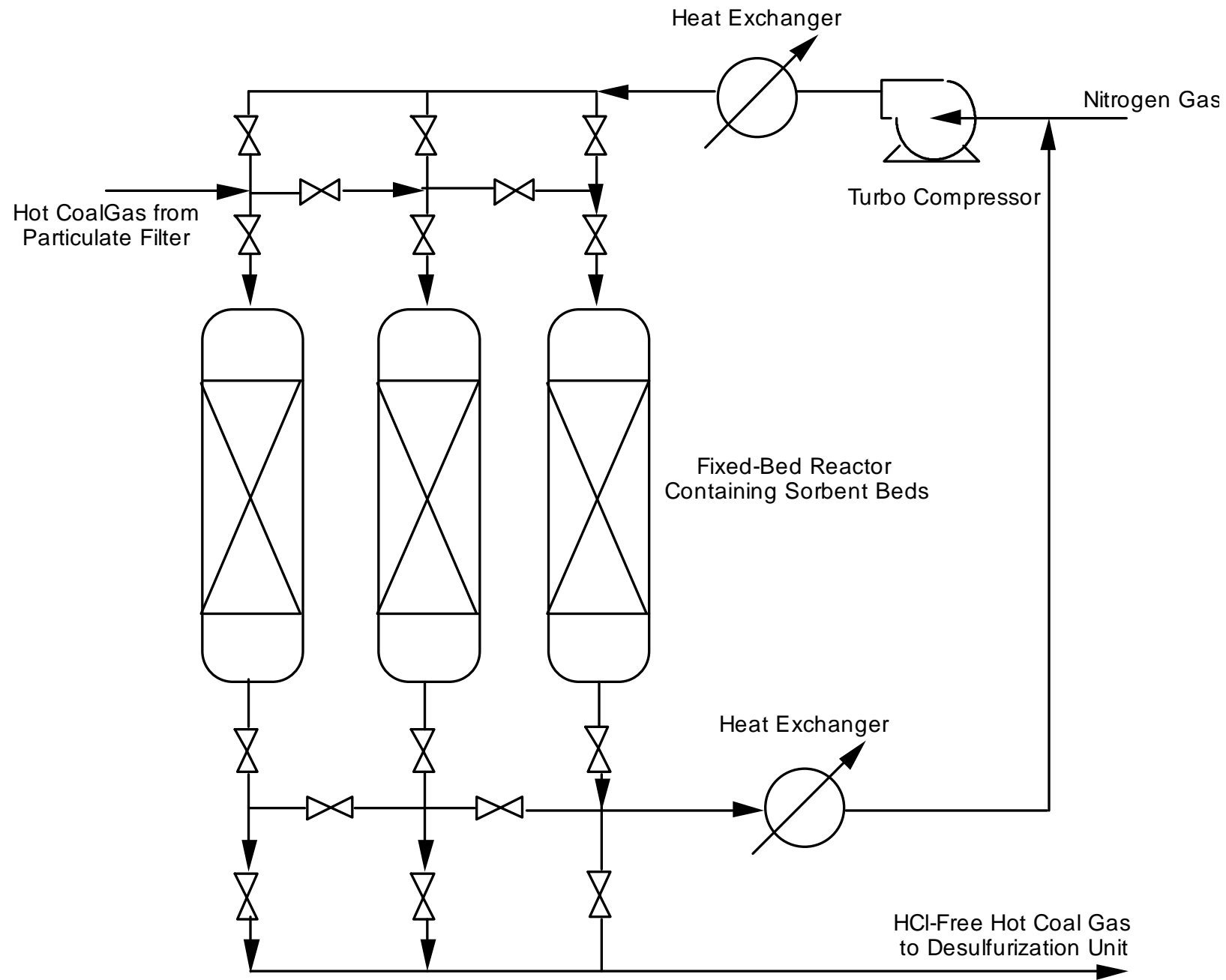

Figure 50. Schematic diagram of a fixed-bed reactor process for $\mathrm{HCl}$ vapor removal from hot coal gas. 
The sorbent beds were designed to operate at an inlet pressure of $385 \mathrm{psig}$ at a temperature of $540^{\circ} \mathrm{C}$. The vessels were assumed to be of carbon steel with refractory lining. The sorbent was assumed to consist of $3 \mathrm{~mm}$ diameter pellets made of $90 \%$ nahcolite and $10 \%$ bentonite binder. The beds were sized for $50 \mathrm{wt} \%$ chloride loading at a space velocity of $2500 \mathrm{~h}^{-1}$. The expected pressure drop through the beds was assumed to be less than 20 psi.

Spent sorbent removal cycle time will be about 15 days based on the assumed $\mathrm{HCl}$ level in the gas stream and the chloride capacity of the sorbent. At the end of the service cycle, the beds will be depressurized and cooled with nitrogen for $100 \mathrm{~h}$ before removing the spent sorbent.

Circulating-fluidized-bed Reactor Configuration: Because the reaction of $\mathrm{HCl}$ vapor with the sorbent at the operating temperature $\left(540^{\circ} \mathrm{C}\right)$ is very rapid and the capacity of the chloride is rather high ( $\sim 50 \mathrm{wt} \%$ chloride in the spent sorbent), a circulating-fluidized-bed reactor was considered. A schematic diagram of a circulating fluidized-bed system is shown in Figure 51. It consists of a sorbent feed system with a lock hopper, CFB reactor with an external cyclone and a standpipe, a loop seal for recycling the sorbent, a discharge system for spent sorbent. GE-CRD used successfully a CFB reactor with an internal cyclone at its pilot plant (Bevan et al., 1995). For commercial size units, an external cyclone is preferred over the internal one.

A high gas velocity was needed because tests at RTI have shown that when the fluidizedbed is operated in the bubbling mode at elevated pressures (10 to $20 \mathrm{~atm}$ ), the sorbent particles had a tendency to agglomerate. Under the bubbling-bed conditions, gas channeling occurred and the chloride capacity of the sorbent particles at the $1 \mathrm{ppm}$ breakthrough level was less than 1/10 of the capacity if the fluidized-bed operated effectively. Note that the capacity of spray-dried sorbent approached $40 \mathrm{wt} \%$ chloride under atmospheric pressure when the reactor was operated in the bubbling mode.

For the case of the CFB configuration, the total pressure, gas composition, and temperature will be the same as the fixed-bed reactor case. The gas velocity was assumed to be $3 \mathrm{~m} / \mathrm{s}(10 \mathrm{ft} / \mathrm{s})$ at the operating temperature and pressure $\left(540^{\circ} \mathrm{C}, 20 \mathrm{~atm}\right)$. The sorbent will be granules in the particle size range of 90 to $150 \mu \mathrm{m}$. The sorbent will be injected into the reactor pneumatically from a pressurized hopper using a screw feeder. The sorbent will be loaded into the pressurized hopper using a lock-hopper system. The spent sorbent will be withdrawn as an overflow from the top of the bed through a standpipe into a pressurized discharge hopper. The sorbent will be discharged from the pressurized hopper using a lock hopper. The sorbent feed and discharge designs are similar to that used at the GE-CRD pilot-plant facility. 


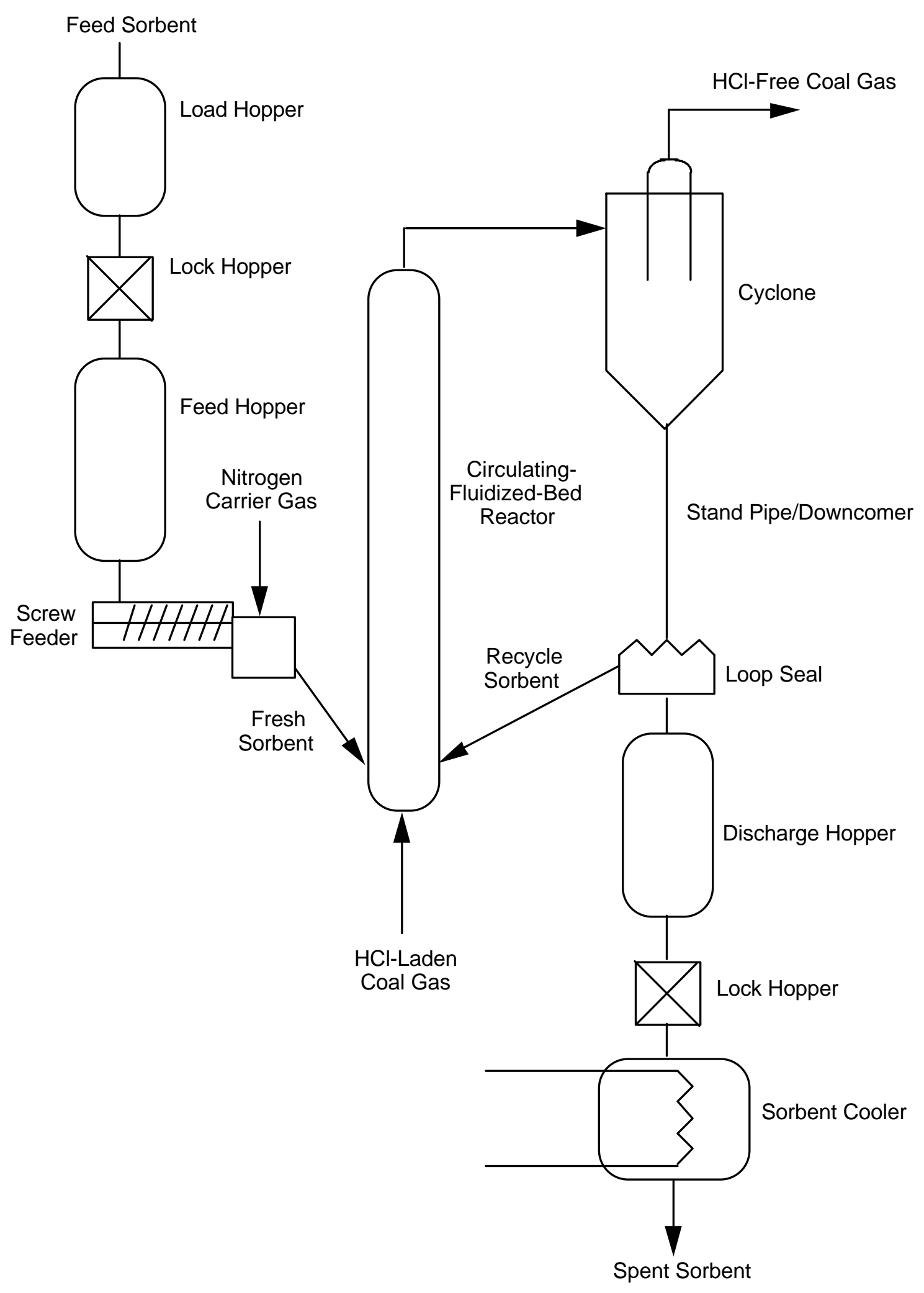

Figure 51. Schematic diagram of a CFB reactor process for the removal $\mathrm{HCl}$ vapor from hot coal gas. 


\section{Sorbent Cost}

SRI made a preliminary cost estimate of nahcolite production from a large-scale mine in the Colorado Green River formation (Krishnan et al., 1986). The cost of the sorbent was estimated to be about $\$ 100 /$ st, in the reasonable range of $\$ 100$ to $\$ 150 /$ st, quotes obtained from the vendor at that time. Recent estimates of solution-mined nahcolite are in the range from $\$ 150$ to $\$ 225 /$ st. Food-grade baking soda would cost nearly double, $\$ 440 /$ st.

Fixed-bed reactors use pellets of made by agglomeration of the powder. Discussions with agglomeration equipment manufacturers and experts at SRI indicated that pelletization (using commercial size disc pelletizers) of the nahcolite powder would cost about $\$ 16 /$ st. Briquetting would be less costly ( $\$ 10 / \mathrm{st})$, but the pellet size will be large, about $2.5 \mathrm{~cm}$ (1-in.) in size. Fluidized-bed reactors use either coarse powder $(90$ to $150 \mu \mathrm{m})$ or granular material produced by spray drying. The cost of spray drying is estimated to be about $\$ 400 /$ st. However, tests conducted at RTI have shown that the spray-dried sorbent has superior reactivity and chloride capacity than the baking soda powder.

Spent sorbent was assumed to be shipped by truck to a commercial disposal site with a suitably lined impoundment area to prevent any possible leaching of toxic materials into the environment. It is expected that the spent sorbent may not be classified as hazardous waste. However, analysis of the spent sorbent from the pilot-scale tests at the GE-CRD gasifier showed some accumulation of lead on the spray-dried sorbents. The accumulated lead on on the baking soda sorbent was only $20 \%$ of that found on the spray-dried sorbent. Because the run with the spray-dried sorbent was only a short duration $(4 \mathrm{~h})$, accumulation of trace metals on that sorbent may not be representative. The test run at the MGCR facility did not show any significant accumulation of trace metals on either the pellets or spray-dried powder. With the lack of any further data at this time on the leaching properties of the spent sorbent, the use of lined disposal facilities was deemed appropriate to obtain realistic cost estimate. The study by FETC (1998) assumed that the ash and the sorbent will be disposed together at a cost of $\$ 8 /$ ton. The study did not specify whether the sorbent would be considered as a hazardous material.

An alternative process scheme to the disposal of hazardous spent sorbent in a lined-facility was considered. In this process scheme, the spent sorbents will be dissolved in water. Any residual and the insoluble matter will be filtered and disposed in a lined-facility. The unreacted $\mathrm{Na}_{2} \mathrm{CO}_{3}$ and product $\mathrm{NaCl}$ in the spent sorbent are very soluble in water. The insoluble residue will be the binders such as bentonite or kaolinite and any ash accumulated. The cost of disposal will be reduced significantly because the amount of material will be about $10 \%$ of the spent sorbent. 
The aqueous solution may contain trace metal impurities and it needs to be treated before it can be discharged. The trace metal impurities in the aqueous solution could be removed by processes such as adsorption on activated carbon and ion exchange process. These methods are used in waste water treatment. Adsorption on activated carbon could remove most of the trace metal impurities, but the activated carbon need to be disposed in lined-facility and its cost would depend on the quantity of activated carbon needed to treat the aqueous solution. Furthermore, the activated carbon is relatively expensive.

Ion exchange processes are used commercially in many applications, including softening of water, demineralization of boiler feed water, and recovery of metals, treatment of aqueous waste for pollution control. Waste treatment processes that use ion exchange include drainage of water from mines, removal of ammonia and nitrates from ground water, and treatment of nuclear waste solution (Rousseau, 1987). The selectivity of ion exchange resins depends on the acidity of the solution $(\mathrm{pH})$ and the nature of the metal ions to be removed. The selectivity of one ion exchange resin for $\mathrm{Pb}^{++}$is 1200 times in relation to $\mathrm{Ca}^{++}$at a $\mathrm{pH}$ of 4 . Other ions such as $\mathrm{Fe}^{+++}$have a selectivity of 325,000 with respect to $\mathrm{Ca}^{++}$at a pH of 2 (McNulty, 1997). Hence, the capacity of the ion exchange resin would depend on the type of metal ion that need to be removed. The cost of the ion exchange process would greatly depend on the type and amount of trace metal ions that need to be removed from the aqueous solution. Because the resins are typically expensive, they need to be regenerated and reused. A single use of the resin is likely to be prohibitively expensive. Because of these reasons and the absence of experimental data, this option was not considered.

\section{Capital Investment}

Capital cost estimates for the high-temperature $\mathrm{HCl}$ removal systems for a 400-MW $\mathrm{MGCC}$ power plant using nahcolite sorbents are shown in Tables 27 and 28. It is assumed that the coal gas to be treated will be from a Texaco-type entrained-bed slagging gasifier operating in oxygenblown mode using Illinois \#6 coal. Table 27 shows the estimate for the fixed-bed reactor whereas Table 28 shows the estimate for the CFB reactor system. The costs are based on mid-1998 U.S. Gulf Coast construction. These include total installed equipment costs (TIC), indirect costs (at $30 \%$ of TIC), contingency (at $20 \%$ of TIC), the initial sorbent charge, and startup costs (at $5 \%$ of TIC). 
Table 27

\section{CAPITAL COST OF THE FIXED-BED REACTOR HCI REMOVAL SYSTEM (Texaco Entrained-Bed, Oxygen-Blown Gasifier, $400 \mathrm{MW}_{\mathrm{e}}$ )}

\begin{tabular}{|c|c|c|}
\hline Equipment & Quantity & Cost $(\$)$ \\
\hline Sorbent vessels & 3 & 915,000 \\
\hline Sorbent cooler blower & 1 & 25,000 \\
\hline Heat exchangers & 2 & $\underline{56,000}$ \\
\hline Total FOB equipment cost & & 996,000 \\
\hline Total installed cost (TIC): (170\% Total FOB Cost) & & $1,693,200$ \\
\hline Indirect costs (30\% of TIC) & & 508,000 \\
\hline Contingency $\quad(20 \%$ TIC) & & 338,600 \\
\hline Initial sorbent charge (200 tons at $\$ 225 /$ ton) & & 45,000 \\
\hline Startup costs ( $5 \%$ of TIC) & & $\underline{84,700}$ \\
\hline Total capital cost (TCC) & & $2,669,500$ \\
\hline
\end{tabular}

The total capital cost (TCC) of the fixed-bed reactor system is approximately $\$ 2.7$ million, and that for the circulating-fluidized-bed reactor is $\$ 0.9$ million. The principal reason for the difference in cost is due to the smaller size of the reactor for the CFB system. Each fixed-bed reactor is simple refractory-lined cylinderical vessel of about $96 \mathrm{~m}^{3}\left(3390 \mathrm{ft}^{3}\right)$ in size and holds 102 tons of sorbent pellets. The fluidized-bed reactor is only $45 \mathrm{~m}^{3}\left(1580 \mathrm{ft}^{3}\right)$ and holds about 8 tons of sorbent. But its design and construction are critical for proper circulation of the sorbent for achieving high chloride removal efficiency. 
Table 28

\section{CAPITAL COST OF THE CIRCULATING-FLUIDIZED-BED REACTOR HCI REMOVAL SYSTEM \\ (Texaco Entrained-Bed, Oxygen-Blown Gasifier, $400 \mathrm{MW}_{\mathbf{e}}$ )}

\begin{tabular}{lrr}
\multicolumn{1}{c}{ Equipment } & Quantity & Cost $\mathbf{\$}$ ) \\
\hline & 1 & \\
Circulating-fluidized-bed reactor & 1 & 150,000 \\
Sorbent Feeder and lock hoppers & 1 & 700,000 \\
Spent sorbent discharge lock hoppers & & 320,000 \\
Total FOB equipment cost & \\
& \\
Total installed cost (TIC): (170\% Total FOB Cost) & 544,000 \\
& \\
Indirect costs (30\% of TIC) & 163,200 \\
Contingency (20\% TIC) & 108,800 \\
Initial sorbent charge (8 tons at \$625/ton) & 5,000 \\
Startup costs (5\% of TIC) & 27,200 \\
Total capital cost (TCC) & \\
\hline
\end{tabular}

\section{Annual Operating Costs}

The annual operating cost estimates for the nahcolite-based chloride removal systems for both types of reactor configurations are detailed in Tables 29 and 30. The various cost assumptions are presented in these tables.

The principal factors in the operating costs are sorbent related items (the cost of feed sorbent and the disposal of spent sorbents), operating labor, and capital-related items. In the case of the fixed-bed reactor system, these costs account for $56.4 \%, 14.2 \%$, and $24.0 \%$, respectively. In the case of CFB system, the sorbent-related, operating labor, and capital-related costs account 
for $84.1 \%, 9.6 \%$, and $7.8 \%$, respectively. The dominance of sorbent related costs are due to (1) a single-time use of the sorbent, (2) the cost of disposal in a lined-facility, and (3) the high cost of preparing spray-dried sorbent. In future, if nahcolite production by solution mining or other methods, is resumed, the cost of nahcolite mineral could decrease significantly. The operating labor costs could be reduced if a single operator-per-shift could be shared with other unit operations in the power plant. The simple $\mathrm{HCl}$ removal unit may not require full attention of a single operator.

\section{Economic Sensitivity Studies}

A set of economic sensitivity studies was performed to test the effects of varying design and economic assumptions on the annual operating costs of the chloride removal systems. The results of these estimates are presented in Table 31.

Assumed changes in the sorbent feed cost, cost of spent sorbent disposal, chloride capacity of the sorbent, and operating labor cost affect the cost of electricity by more than $10 \%$. The capital related costs (capital cost and capital recovery factor) have less influence on the cost of electricity.

Calculations were also made for a case in which nahcolite powder sorbent will be used without any further treatment. This case represents the circulating-fluidized-bed operation in which the raw powder will be injected. As found in GE-CRD pilot-plant operation, such powder injection would require a gas residence time of about $10 \mathrm{~s}$ (instead of assumed $5 \mathrm{~s}$ for spray-dried sorbents) and the sorbent utilization would be $55 \%$ (assumed to be $80 \%$ for spray-dried sorbents and $90 \%$ for fixed-bed reactor pellets). The longer residence time and lower chloride capacities changed the equipment sizing. The calculations showed a TIC of $\$ 1,088,000$ and a TCC of $\$ 1,693,400$. The annual operating cost was calculated to be $\$ 5,311,500$, corresponding to a cost of electricity of $\$ 0.0018 / \mathrm{kWh}$ (18 mills $/ \mathrm{kWh}$ ), more than that calculated for the spray-dried sorbents. 


\section{Table 29}

\section{ANNUAL COST OF THE FIXED-BED REACTOR}

HCI REMOVAL SYSTEM

(Texaco Entrained-Bed, Oxygen-Blown Gasifier, $400 \mathrm{MW}_{\mathrm{e}}$ )

\section{Materials}

\begin{tabular}{llr}
\multicolumn{1}{c}{ Materials } & \multicolumn{1}{c}{ Rate } & Annual Cost (\$) \\
\hline & & \\
Sorbent & $\$ 225 / \mathrm{st}$ & 774,800 \\
Maintenance Materials & $3 \%$ of TIC & 50,800 \\
Sorbent Disposal & $\$ 250 / \mathrm{st}$ & 827,500 \\
Labor & & \\
$\quad$ Operating & $\$ 45 / \mathrm{h}$ & 394,200 \\
$\quad$ Maintenance & $2 \%$ TIC & 33,900 \\
Fixed Costs & $1.5 \%$ TIC & \\
$\quad$ General and Administrative & $2.5 \%$ TIC & 42,300 \\
$\quad$ Taxes and Insurance & $25 \%$ TCC & 667,400 \\
$\quad$ Cost of Capital & & $2,786,200$ \\
Total Annual Operating Costs & & \\
$\quad$ Annual Operating Cost $(\$ / \mathrm{kWh})$ & & 0.00094 \\
Annual Operating Cost (mills/kWh) & & 0.94 \\
\hline
\end{tabular}


Table 30

ANNUAL COST OF THE CIRCULATING-FLUIDIZED-BED REACTOR HCI REMOVAL SYSTEM (Texaco Entrained-Bed Oxygen Blown Gasifier, $400 \mathrm{MW}_{\mathrm{e}}$ )

Materials

Rate

$\$ 625 /$ st

$3 \%$ of TIC

$\$ 250 /$ st

$\$ 45 / \mathrm{h}$

$2 \% \mathrm{TIC}$

$1.5 \%$ TIC

$2.5 \%$ TIC

$25 \%$ TIC

Cost of capital

Total Annual Operating Costs

Annual Operating Cost ( $\$ / \mathrm{kWh})$

Annual Operating Cost (mills/kWh)

0.0014

Annual Cost (\$)

$2,481,300$

16,300

992,500

394,200

10,900

8,200

13,600

212,100

$4,129,000$

1.39 
Table 31

\section{ECONOMIC SENSITIVITY ANALYSIS OF HCI VAPOR REMOVAL SYSTEM}

\begin{tabular}{|c|c|c|c|}
\hline \multirow[b]{2}{*}{ Parameter } & \multicolumn{3}{|c|}{ Operating Cost (\$mills/kWh) } \\
\hline & Value & Fixed-Bed Reactor & CFB Reactor \\
\hline \multirow[t]{3}{*}{ Capital investment } & $75 \%$ & 0.88 & 1.37 \\
\hline & $100 \%$ & 0.94 & 1.39 \\
\hline & $125 \%$ & 0.99 & 1.40 \\
\hline \multirow[t]{2}{*}{ Capital recovery } & $15 \%$ & 0.85 & 1.36 \\
\hline & $25 \%$ & 0.94 & 1.39 \\
\hline \multirow[t]{4}{*}{ Feed sorbent cost } & $\$ 150 /$ st & 0.85 & 1.29 \\
\hline & $\$ 225 / \mathrm{st}$ & 0.94 & 1.39 \\
\hline & $\$ 275 / \mathrm{st}$ & 0.99 & 1.45 \\
\hline & $\$ 440 /$ st & 1.18 & 1.67 \\
\hline Nonhazardous Waste Disposal & $\$ 10 /$ st & 0.67 & 1.06 \\
\hline \multirow[t]{3}{*}{ Sorbent capture Capacity $(\mathrm{wt} \% \mathrm{Cl})$} & 30 & 1.29 & 2.16 \\
\hline & 40 & 1.07 & 1.68 \\
\hline & 50 & 0.94 & 1.39 \\
\hline \multirow[t]{2}{*}{ Operating Labor (Operator/shift) } & 0.5 & 0.87 & 1.32 \\
\hline & 1.0 & 0.94 & 1.39 \\
\hline
\end{tabular}




\section{CONCLUSIONS AND RECOMMENDATIONS}

Based on the experimental results and theoretical considerations, the following conclusions were derived:

- $\quad$ Bench-scale experiments in the fixed- and fluidized-bed reactors have demonstrated that nahcolite pellets and granules are capable of reducing $\mathrm{HCl}$ levels to less than $1 \mathrm{ppm}$ in high temperature coal gas streams in the temperature range from $400^{\circ}$ to $650^{\circ} \mathrm{C}$.

- $\quad$ The sorbents, prepared by pelletizing or spray-drying nahcolite powder, have a high capacity of absorbing $\mathrm{HCl}$ vapor. The chloride levels in the spent sorbents approach the theoretical capacity.

- A mathematical analysis of $\mathrm{HCl}$ breakthrough data and chloride level in the spent sorbents suggests that the rate of $\mathrm{HCl}$ uptake by the sorbent is governed by gas-phase diffusion, and it could be described by an overall first-order kinetics.

- Operating parameters such as total pressure, steam levels, $\mathrm{H}_{2} \mathrm{~S}$ concentration, and composition of the major components have only a minor effect on the $\mathrm{HCl}$ absorption by the nahcolite sorbents.

- $\quad$ Operation of the fluidized-bed reactors under bubbling-mode causes agglomeration of the sorbent and channeling of the gas, reducing the chloride capacity. Aggressive fluidized-bed conditions approaching entrained-bed velocities would allow good contact between the sorbent particles and the gas stream. However, particle capture devices such as cyclones are necessary to return entrained particles to the fluidized-bed and allow increased contact time.

- A test in a pilot-scale fixed-bed gasifier established that nahcolite can be used successfully for reducing $\mathrm{HCl}$ vapor with high sorbent utilization.

- Accumulation of trace metals on the spent sorbents is not certain in the tests with gas streams from operating gasifiers.

- $\quad$ The cost of $\mathrm{HCl}$ vapor removal is estimated to be small, about $\$ 0.001 / \mathrm{kWh}$ (about $1 \mathrm{mills} / \mathrm{kWh}$ ) for the case of an entrained-bed, oxygen-blown gasifier IGCC system. The principal cost component is sorbent-related-the cost of raw sorbent, preparation of sorbents (especially for circulating-fluidized-bed systems), and disposal of spent sorbents if they are considered hazardous waste. The next major cost component is the operating labor costs. The capital-related costs are less than $25 \%$ of the operating costs. 
Based on the above conclusions, the following recommendations are made:

- $\quad$ Testing of $\mathrm{HCl}$ removal using nahcolite sorbent should be continued further, especially using gas streams from operating gasifiers. These tests are necesary to identify any engineering issues and define the cost of $\mathrm{HCl}$ removal more accurately.

- Some coal utilization applications such as chemicals manufacturing and IGCC systems with fuel cells could use $\mathrm{HCl}$ levels significantly lower than $1 \mathrm{ppm}$. Research should focus on identifying and developing concepts that would reduce $\mathrm{HCl}$ vapor levels to parts-per-billion (ppb) levels. 


\section{REFERENCES}

Anderson, G. L., F. O. Berry, and M. N. Gross. 1984. "Development of the Mixed Metal Oxide Process for High-temperature Fuel Gas Desulfurization and a Ceramic-Supported Molten Alkali Carbonate Sorbent for High-temperature $\mathrm{HCl}$ Removal." In Proceedings of the Fourth Annual Contractor's Meeting on Contaminant Control in Hot Coal-Derived Gas Streams, Morgantown, WV.

Ayala, R. E., 1991. "Enhanced Durability of High-Temperature Desulfurization Sorbents for Movig-Bed Applications. Base Program: Development and Testing of Zinc Ferrite Sorbents. Topical Report. U.S. Department of Energy Report No.: DOE/MC/2503-3045.

Ayala, R., V. S. Venkataramani, and T. L. Chuck. 1995. "Hot Gas Desulfurization Using Moving-Bed Reactor." In Proceedings of the Advanced Coal-Fired Power and Environmental Systems 97 Conference, U.S. Department of Energy Report No.: DOE/METC-97/1046.

Bakker, W.T., and R. A. Perkins. 1991. "The Effect of Coal Bound Chlorine on Corrosion of Coal Gasification Plant." In Proceedings of International Conference on Chlorine in Coal, J. Stringer and D.D. Banerjee, Eds., Elsevier , pp. 63-83.

Bevan, S., D. Najewicz, E. Gal, A. H. Furman, R. Ayala, and A. Feitelberg. 1994. "Integrated Operation of a Pressurized Gasifier, Hot Gas Desulfurization Systems and Turbine Simulator." In Proceedings of the Coal-Fired Power Systems 94 -- Advances in IGCC and PFBC Review Meeting, U.S. Department of Energy Report No.: DOE/METC-94/1008, pp. 222-235.

Bevan, S., D. Najewicz, R. Ayala, A. Feitelberg, and A. H. Furman. 1994. "Integrated Operation of a Pressurized Gasifier, Hot Gas Desulfurization Systems and Turbine Simulator." In Proceedings of the Advanced Coal-Fired Power Systems 95 Review Meeting, U.S. Department of Energy Report No.: DOE/METC-95/1018, pp. 187-201.

Chou, C. L. 1991. "Distribution and Forms of Chlorine in Illinois Basin Coals." In Proceedings of International Conference on Chlorine in Coal, J. Stringer and D.D. Banerjee, eds., Elsevier, pp. 11-29.

COGRAN. 1987. "Coal Gasification: Direct Applications and Synthesis of Chemicals and Fuels - A Research Needs Assessment," U.S. Department of Energy Report No. DOE/ER026.

Demuth, J. E., and H. G. Smith. 1998. "Pinon Pine Project Gasifier Starup." In Proceedings of the Advanced Coal-Based Power and Environmental Systems 98 Conference, U.S.

Department of Energy Report No.: DOE/FETC-98/1072. 
Fahey, J. J. 1962. "Saline Minerals of the Green River Formation," Geological Survey professional paper 405.

Farris, C. B. and C. J. Mains. 1978. "Dawsonite and Nahcolite Survey, Vol 1. Reserves, Technology, Economics,and Market Assessment," Colorado School of Mines Research Institute, Report to U.S. Department of Energy, Report IDO-183-1.

FETC. 1998. “Texaco Gasifier IGCC Base Cases PED-IGCC-98-001 (Rev 1). Office of Systems Engineering and Analysis, Process Engineering Division, U.S. Department of Energy, Federal Energy Technology Center.

Fusch, Y. and K. Schwerdtfeger. 1996. "Hot Dechlorination and Hot Desulfurization of Reducing Gases with Lime Pellets." in High Temperature Gas Cleaning, ed. E. Schmidt, P. Gang, T. Pilz, and A. Dittler, Instiut für Mechanischle verfaherstechnik and Mechanik, Karlsuhe, Germany.

Gal, E., A. H. Furman, and R. Ayala. 1992. "Integrated Operation of a Pressurized Fixed-Bed Gasifer and Hot Gas Cleanup Systems," In Proceedings of the Twelfth Annual Gasification and Gas stream Cleanup Systems Contractors Review Meeting, U.S. Department of Energy Report No.: DOE/METC-92/6128, pp. 84-94.

Gangwal, S. K., T. M. Paar, and W. J. McMichael. 1990. Effect/Fate of Chlorides in the ZincTitanate Hot-Gas Desulfurization Process. Final Report submitted to Texaco, Inc.

Gillis, E. A. 1980. "Fuel Cells for Electric Utilities," Chem. Eng. Prog.

Gluskoter, H. J., and O. W. Rees. 1964. Chlorine in Illinois Coal. Circular No. 372, Illinois State Geological Survey, Urbana, IL.

Grindley, T. 1990. "Effect of Chlorine on Hot Gas Desulfurization Sorbents." In Proceedings of the Tenth Annual Gasification and Gas Stream Cleanup Systems Contractor's Review Meeting, Morgantown, WV, pp. 215-221.

Gupta, R. P., and W. S. O'Brien. 1992. Desulflurization of Hot Fuel-Gas Produced From High Chlorine Illinois Coals, Final Report to Illinois Center for Research on Sulfur in Coal, Carbondale, IL.

Gupta, R. P. and S. K. Gangwal. 1992. Enhanced Durability of Desulfurization Sorbents for Fluidized-Bed Applications, Report No.: DOE/MC/25006-3271, , U.S. Department of Energy, Morgantown, WV.

Ham, D., A. Gelb, G. Lord, and G. Simmons, 1984. Hot-Gas Chloride Cleanup for Molten Carbonate Fuel Cells. Report No. DOE/MC/16242-1554, Morgantown Energy Technology Center, U.S. Department of Energy, Morgantown, WV.

Jain, S. C., and T. Grindley. 1991. "Effects of Chlorine on Hot Gas Desulfurization Sorbents." In Proceedings of International Conference on Chlorine in Coal., J. Stringer and D.D. Banerjee, Eds., Elsevier, pp. 85-108. 
Hirschenhofer, J. H., D. B. Stauffer, and R. R. Engleman, 1994. Fuel Cells: A Handbook (Revision 3). U.S. Department of Energy Report DOE/METC-94/1006.

Katalco Corporation. 1985 Katalco 59-3 Chloride Guard Catalyst. Product Information Sheet. Katalco Corporation, Oak Brook, IL 60521.

Kinoshita, K., F. R. McLarnon and E. J. Cairns. 1988. Fuel Cells: A Handbook, Report No. DOE/METC-88/6096. Morgantown Energy Technology Center, U.S. Department of Energy, Morgantown, WV.

Krishnan, G. N., G. T. Tong, B. J. Wood, and N. Korens. 1986. High-Temperature Coal-Gas Chloride Cleanup for MCFC Applications. Report No. DOE/ME/21167-2080. Morgantown Energy Technology Center, U.S. Department of Energy, Morgantown, WV.

Krishnan, G. N., R. P. Gupta, A. Canizales, S. Shelukar, and R. Ayala. 1996. "Removal of Hydrogen Chloride from Hot Coal Gas Streams." In High Temperature Gas Cleaning, E. Schmidt, P. Gang, T. Pilz, and A. Dittler, eds. Instiut für Mechanischle verfaherstechnik and Mechanik, Karlsuhe, Germany.

Lyke, S.E., L.J. Sealock, Jr., and G. L. Roberts. 1985. Development of a Hot Gas Cleanup System for Integrated Coal Gasification/Molten Carbonate Fuel Cell Power Plants. Report No. DOE/MC/19077-1830. Morgantown Energy Technology Center, U.S. Department of Energy, Morgantown, WV.

Marlow, J. H, J. Pavel and E. Vidt. 1981. "A Projection of Coal Gas Properties Considered from the Viewpoint of a Coal Gas Combined-Cycle Plant," Stationary Gas Turbine Alternate Fuels, J. S. Clark and S. M. DeCorso, eds. ASTM Technical Publication 809, p. 255.

McNulty, J. T. 1997. The Many Faces of Ion Exchange Resins, Chem. Eng., June 1997, p 94.

Moorehead, E. L., G. B. Henningsen, S. Katta, and J. J. O’Donnell. 1996. "Hot Gas Desulfurization Using Transport Reactors." In Proceedings of the Advanced Coal-Based Power Systems 96 Review Meeting, U.S. Department of Energy Report No.: DOE/METC96/1037.

Perkins, R. A., D. L. Marsh, and P. R. Clark. 1990. Corrosion in Syngas Coolers of Entrained Slagging Gasifiers. Report No. EPRI GS-6971, Electric Power Research Institute, Palo Alto, CA.

Pigeaud, A., and G. Eilemski. 1992. "Effect of Coal-Derived Trace Species on the Performance of Carbonate Fuel Cells." In Proceedings of the Twelfth Annual Gasification and Gas Stream Cleanup Systems Contractors Review Meeting, U.S. Department of Energy Report No.: DOE/METC-92/6128, pp. 42-45.

Rousseau, R. W. 1987. Handbook of Separation Process Technology, John Wiley and Sonds, New York, p 713. 
Ruch, R.R., H.J. Gluskoter, and N.F. Shimp. 1974a. Occurrence and Distribution of Potentially Volatile Trace Elements in Coal. Report No. EPA-650/2-74-054, U.S. Environmental Protection Agency, Washington, DC.

Ruch, R.R., H.J. Gluskoter, and N.F. Shimp. 1974b. Occurrence and Distribution of Potentially Volatile Trace Elements in Coal: A Final Report. Environmental Geology Notes No. 72, Illinois State Geological Survey, Urbana, IL.

TRW. 1981. Monitoring Contaminants in Coal Derived Gas for Molten Carbonate Fuel Cells. Final Report to Argonne National Laboratory under contract No. 31-109-38-6108.

U.S. Bureau of Mines. 1967. Process Development in Removing Sulfur Dioxide from Hot Flue Gases, Part 3: Pilot Plant Study of Alkalized Alumina System for $\mathrm{SO}_{2}$ Removal, Report of Investigation 7021.

Walters, J. K. and C. Akosman. 1996. "The Removal of $\mathrm{HCl}$ from Hot Gases with Solid Sorbents." in High Temperature Gas Cleaning, E. Schmidt, P. Gang, T. Pilz, and A. Dittler, eds, Instiut für Mechanischle verfaherstechnik and Mechanik, Karlsuhe, Germany. 